\title{
GROUND-WATER USE IN THE COASTAL PLAIN OF MARYLAND, 1900-1980
}

\author{
By Judith C. Wheeler and Franceska D. Wilde
}

\section{U.S. GEOLOGICAL SURVEY}

Open-File Report 87-540

Prepared in cooperation with the

MARYLAND GEOLOGICAL SURVEY and the MARYLAND WATER RESOURCES ADMINISTRATION

Towson, Maryland

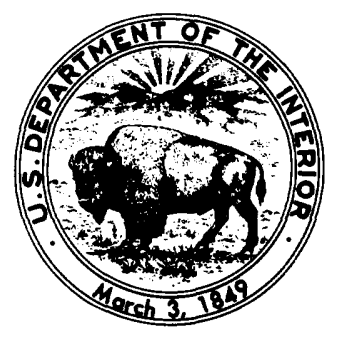
1989 


\section{DEPARTMENT OF THE INTERIOR}

MANUEL LUJAN, JR. , Secretary

U.S. GEOLOGICAL SURVEY

Dallas L. Peck, Director

For additional information write to:

District Chief

U.S. Geological Survey

208 Carroll Building

8600 La Salle Road

Towson, Maryland 21204
Copies of this report can be purchased from:

Books and Open-File Reports Section

U.S. Geological Survey

Box 25425, Federal Center

Denver, Colorado 80225 


\section{CONTENTS}

\section{$\longrightarrow$}

Page

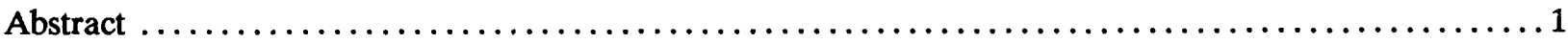

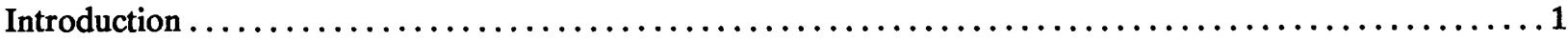

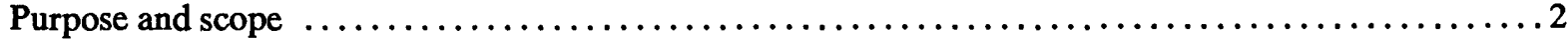

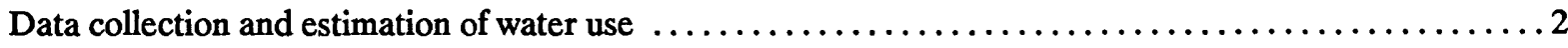

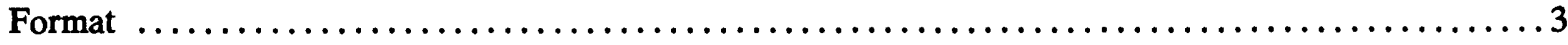

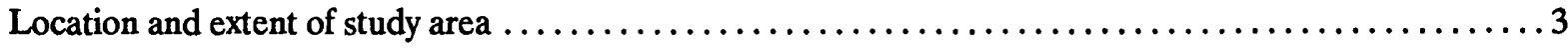

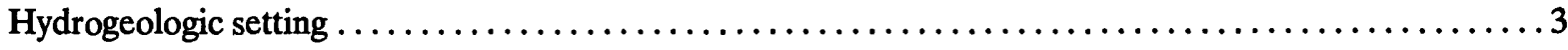

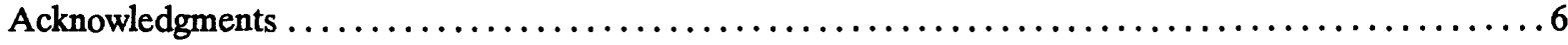

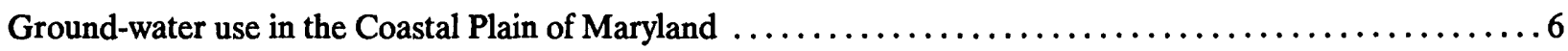

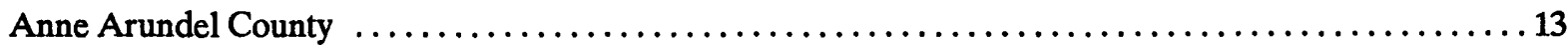

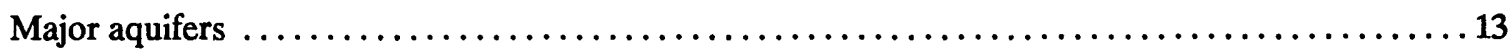

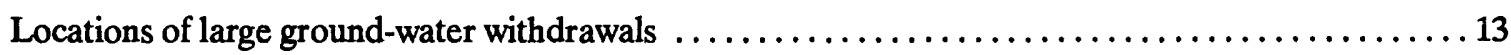

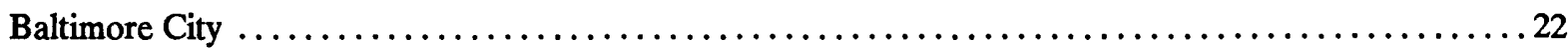

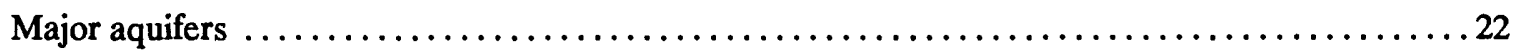

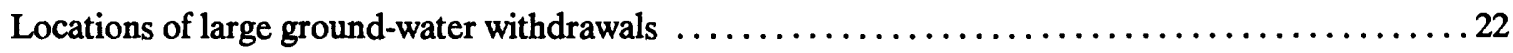

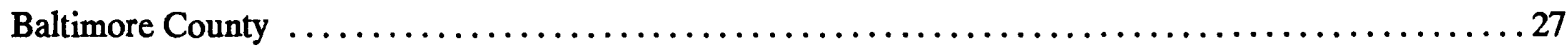

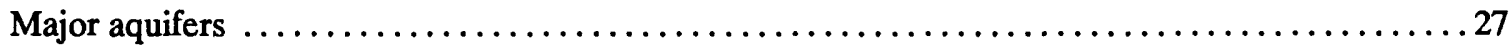

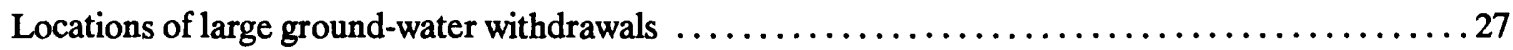

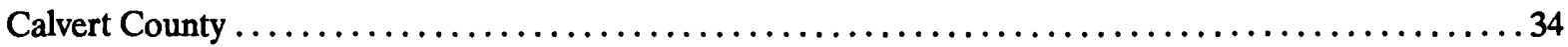

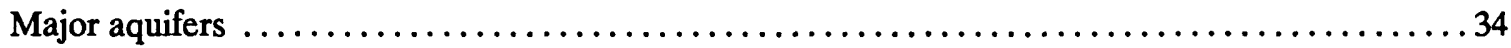

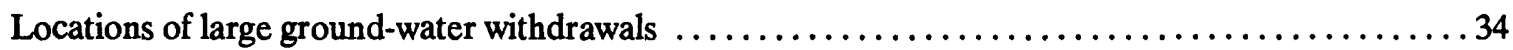

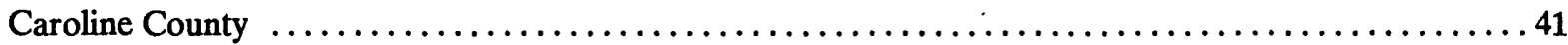

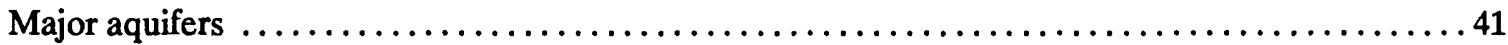

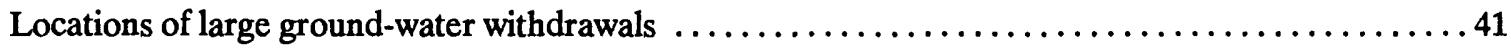

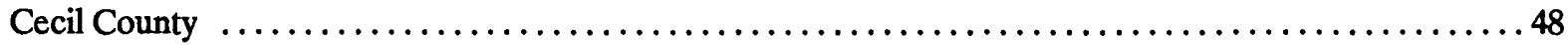

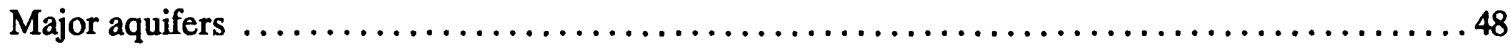

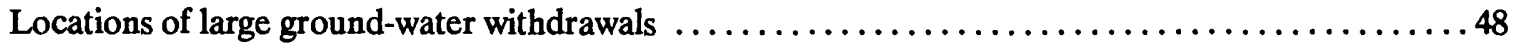

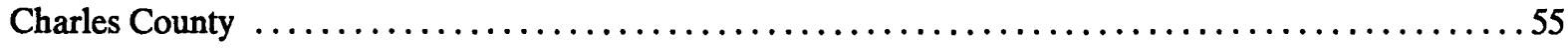

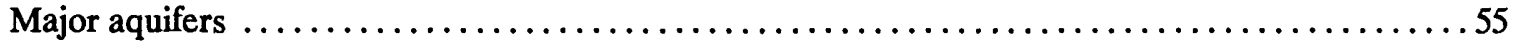

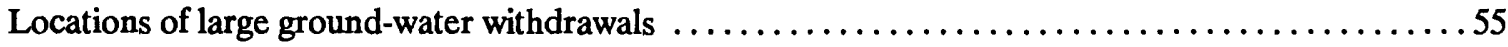




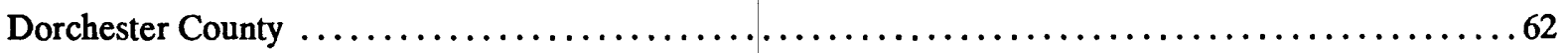

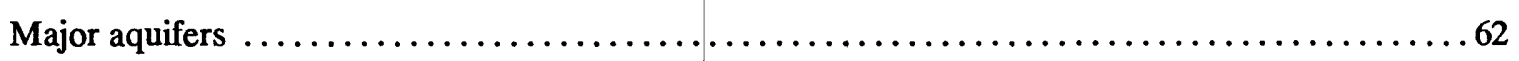

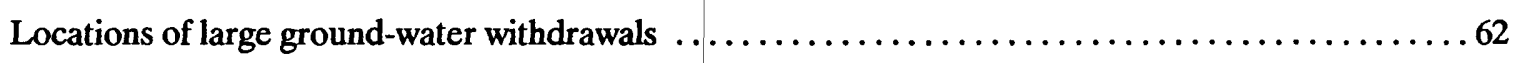

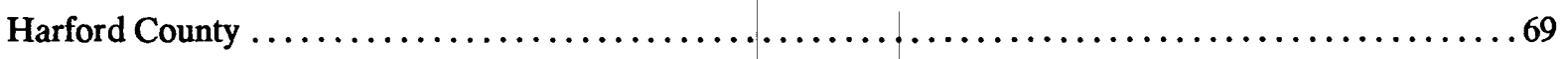

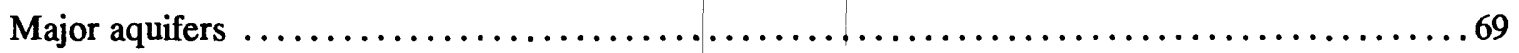

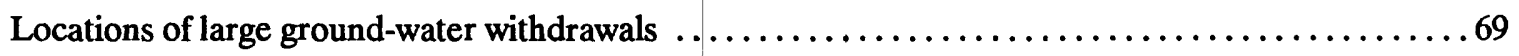

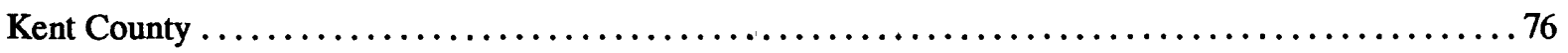

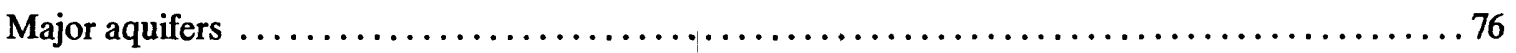

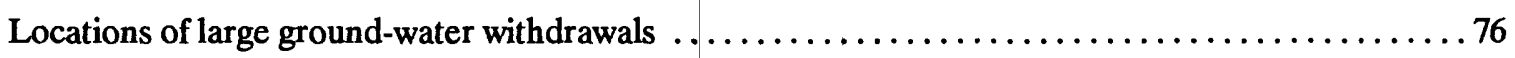

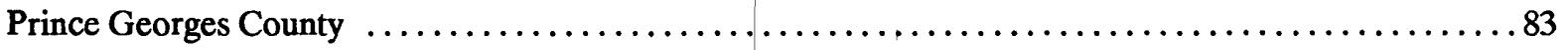

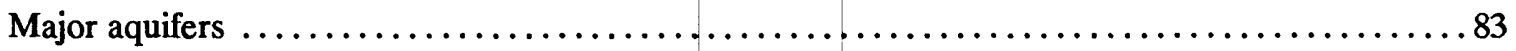

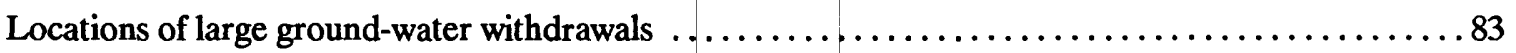

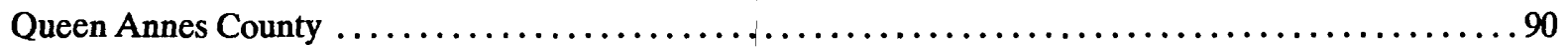

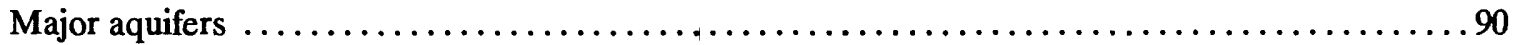

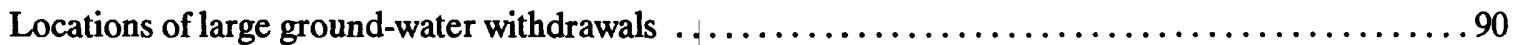

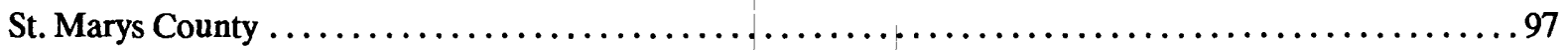

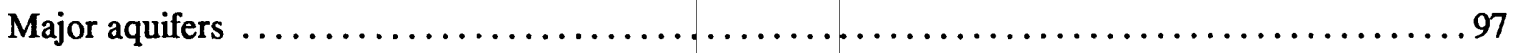

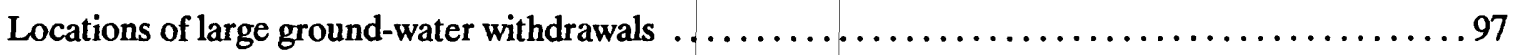

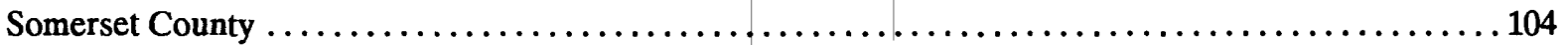

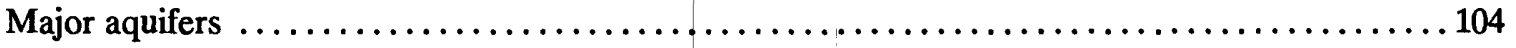

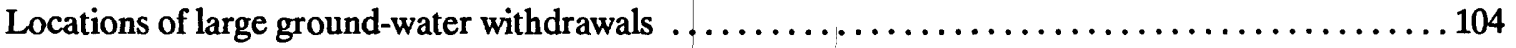

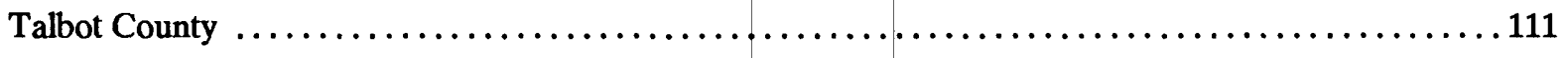

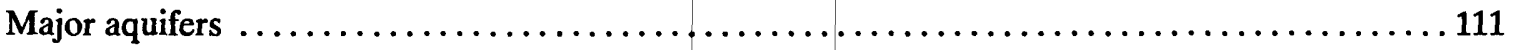

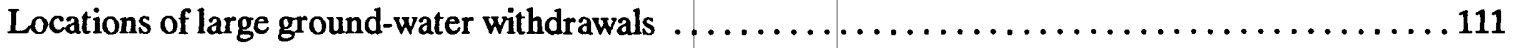

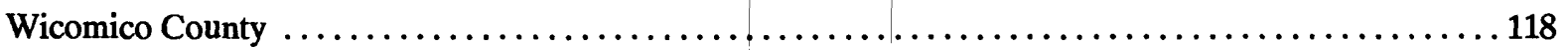

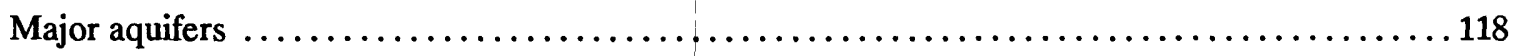

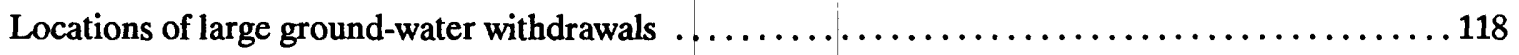

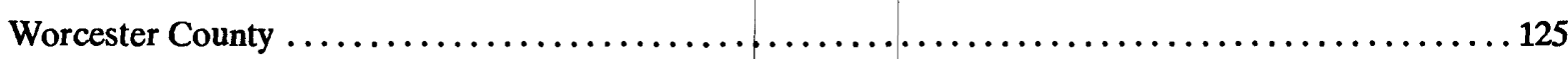

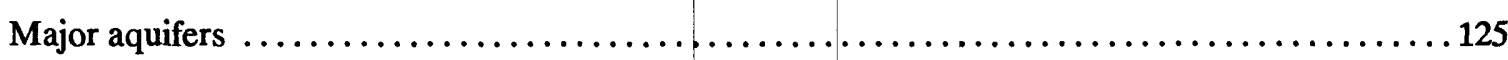

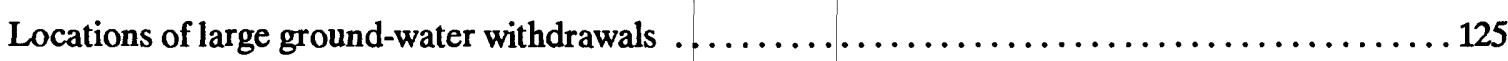




\section{Contents--Continued}

Page

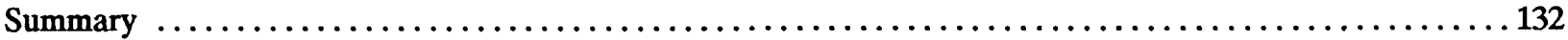

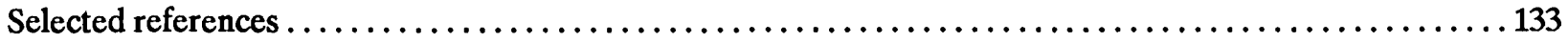

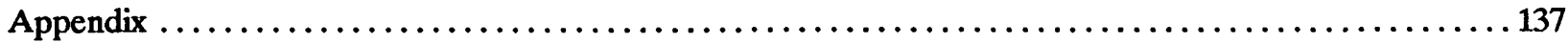

Ground-water withdrawals by large users in the Coastal Plain area

by county and city for 1900 through 1980

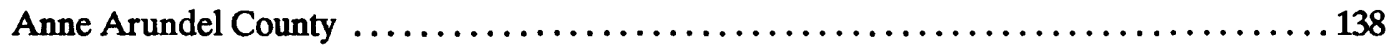

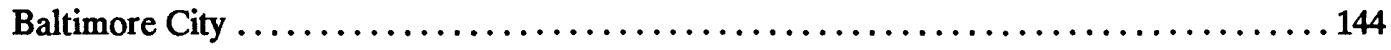

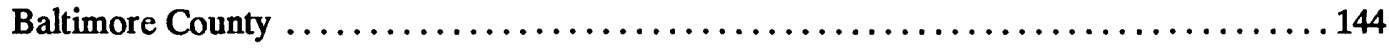

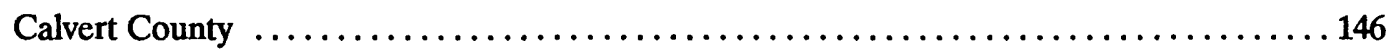

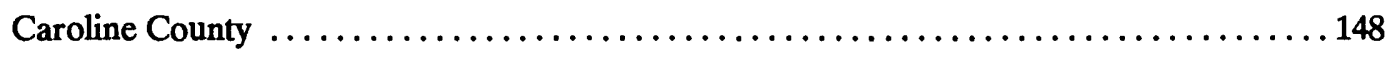

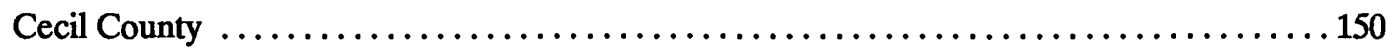

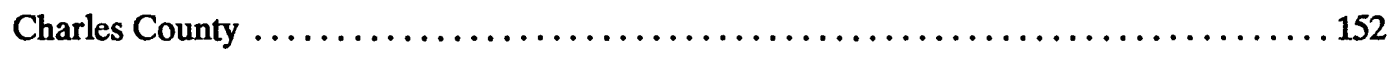

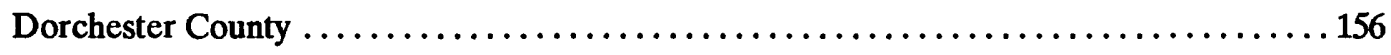

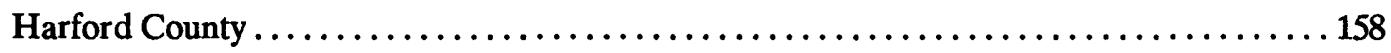

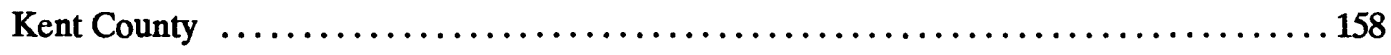

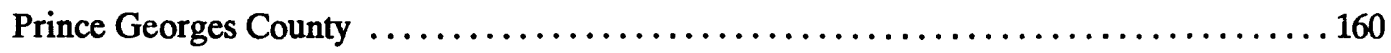

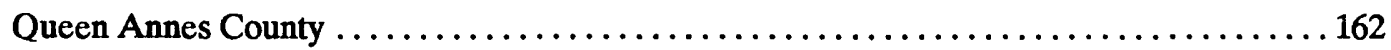

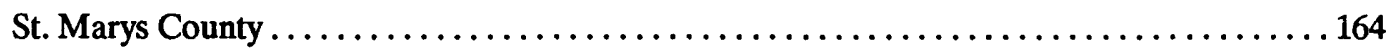

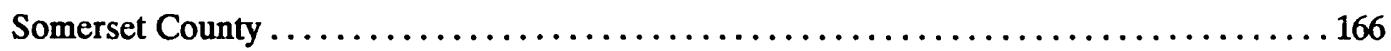

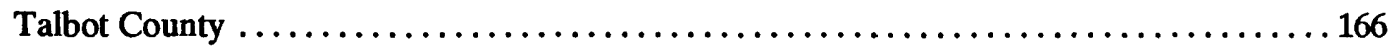

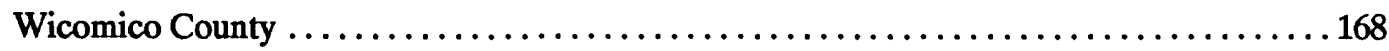

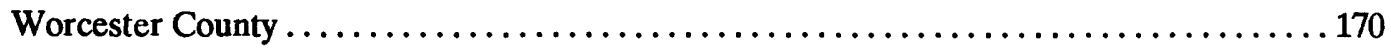

\section{ILLUSTRATIONS}

Figure

1. Map showing location and extent of the Coastal Plain in Maryland $\ldots \ldots \ldots \ldots \ldots \ldots \ldots \ldots \ldots \ldots$

A. Boundaries of physiographic provinces

B. Location and extent of study area

2. Hydrogeologic section A-A' through the study area 


\section{ILLUSTRATIONS--Continued}

Figure

3. Graph showing ground-water withdrawals by use in the Coastal Plain province

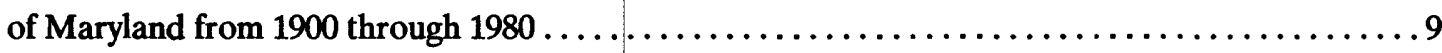

4. Graph showing ground-water use in the Maryland Coastal Plain and percentage for each type of use, for decade years 1900 through 1980 .10

5. Graph showing large ground-water withdrawals by aquifers in the Maryland Coastal Plain from 1900 through 1980 .11

6-8. Graphs for Anne Arundel County showing:

6. Ground-water withdrawals by use from 1940 through 1980 .14

7. Ground-water use and percentage for each type of use, for $1940,1950,1960,1970$ and 1980 15

8. Large ground-water withdrawals by aquifers from 1940 through $1980 \ldots \ldots \ldots \ldots \ldots \ldots$ 9-10. Maps showing locations of large ground-water withdrawals in Anne Arundel County for:

9. 1940, 1950, 1960, 1970, and 1980

10. Aquifers for 1940, 1950, 1960, 1970, and 1980

11-12. Graphs for the Coastal Plain area of Baltimore City showing:

11. Ground-water withdrawals from 1900 through $1980 \ldots \ldots \ldots \ldots \ldots \ldots \ldots \ldots \ldots$

12. Large ground-water withdrawals by aquifers from 1900 through $1980 \ldots \ldots \ldots \ldots \ldots 23$

13-14. Maps showing locations of large ground-water withdrawals

in the Coastal Plain area of Baltimore City for:

13. $1930,1940,1950,1960,1970$, and 1980 24

14. Aquifers for 1930, 1940, 1950, 1960, 1970, and 1980

15-17. Graphs for the Coastal Plain area of Baltimore County showing:

15. Ground-water withdrawals by use from 1930 through 1980 28

16. Ground-water use and percentage for each type of use, for $1930,1940,1950,1960,1970$, and 1980 .

17. Large ground-water withdrawals by aquifers from 1930 through 1980

18-19. Maps showing locations of large ground-water withdrawals in the Coastal Plain area of Baltimore County for:

18. $1930,1940,1950,1960,1970$, and 1980

19. Aquifers for 1930, 1940, 1950, 1960, 1970, and 1980 


\section{ILLUSTRATIONS--Continued}

Page

Figures

20-22. Graphs for Calvert County showing:

20. Ground-water withdrawals by use from 1940 through $1980 \ldots \ldots \ldots \ldots \ldots \ldots \ldots . \ldots . \ldots$

21. Ground-water use and percentage for each type of use,

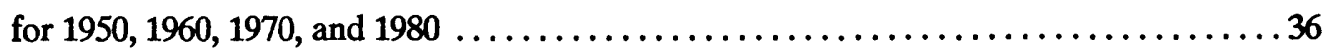

22. Large ground-water withdrawals by aquifers from 1940 through $1980 \ldots \ldots \ldots \ldots \ldots . \ldots 37$

23-24. Maps showing locations of large ground-water withdrawals in Calvert County for:

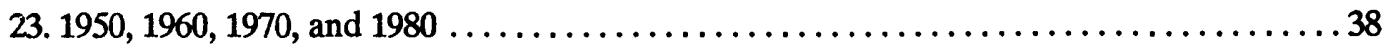

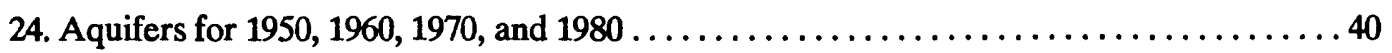

25-27. Graphs for Caroline County showing:

25. Ground-water withdrawals by use from 1950 through $1980 \ldots \ldots \ldots \ldots \ldots \ldots \ldots 2$

26. Ground-water use and percentage for each type of use,

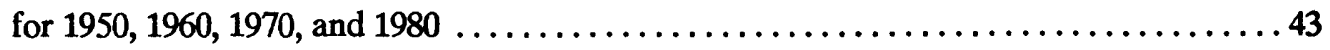

27. Large ground-water withdrawals by aquifers from 1950 through $1980 \ldots \ldots \ldots \ldots \ldots 44$

28-29. Maps showing locations of large ground-water withdrawals in Caroline County for:

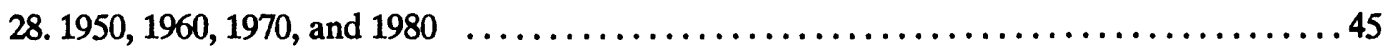

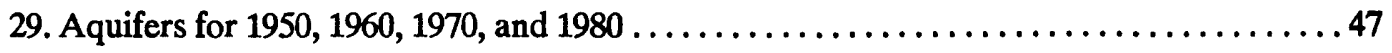

30-32. Graphs for the Coastal Plain area of Cecil County showing:

30. Ground-water withdrawals by use from 1950 through $1980 \ldots \ldots \ldots \ldots \ldots \ldots \ldots 49$

31. Ground-water use and percentage for each type of use,

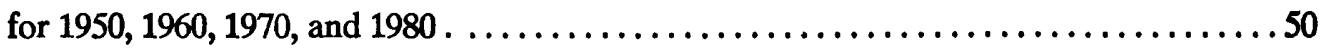

32. Large ground-water withdrawals by aquifers from 1950 through $1980 \ldots \ldots \ldots \ldots \ldots \ldots 1$

33-34. Maps showing locations of large ground-water withdrawals in the Coastal Plain area of Cecil County for:

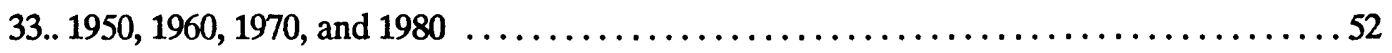

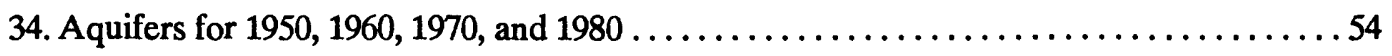

35-37. Graphs for Charles County showing:

35. Ground-water withdrawals by use from 1950 through $1980 \ldots \ldots \ldots \ldots \ldots \ldots \ldots$

36. Ground-water use and percentage for each type of use,

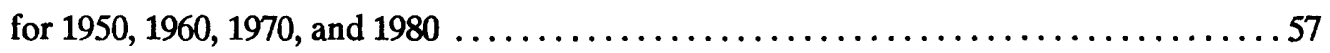

37. Large ground-water withdrawals by aquifers from 1950 through $1980 \ldots \ldots \ldots \ldots \ldots 58$ 


\section{ILLUSTRATIONS--Continued}

Figures

38-39. Maps showing locations of large ground-water withdrawals in Charles County for:

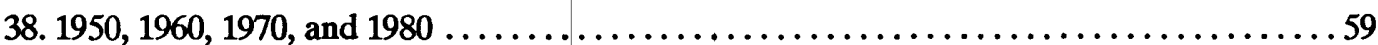

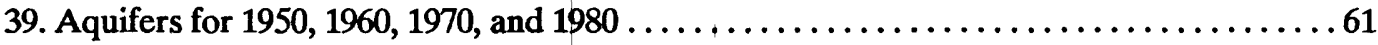

40-42. Graphs for Dorchester County showing:

40. Ground-water withdrawals by use from 1950 through $1980 \ldots \ldots \ldots \ldots \ldots \ldots \ldots \ldots 6$

41. Ground-water use and percentage for each type of use,

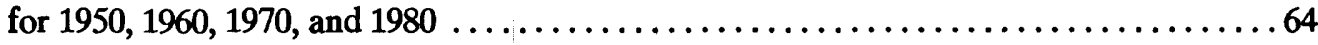

42. Large ground-water withdrawals by aquifers from 1950 through $1980 \ldots \ldots \ldots \ldots \ldots 65$

43-44. Maps showing locations of large ground-water withdrawals in Dorchester County for:

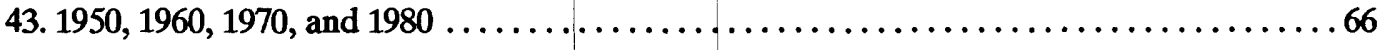

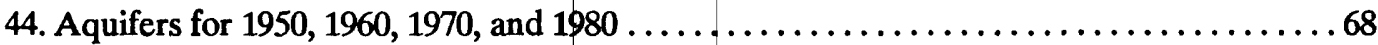

45-47. Graphs for the Coastal Plain area of Harford County showing:

45. Ground-water withdrawals by use from 1950 through $1980 \ldots \ldots \ldots \ldots \ldots \ldots \ldots$

46. Ground-water use and percentage for each type of use,

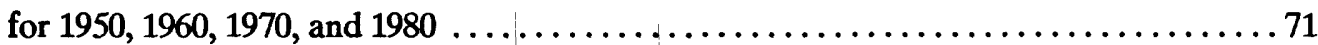

47. Large ground-water withdrawals by aquifers from 1950 through $1980 \ldots \ldots \ldots \ldots \ldots 72$

48-49. Maps showing locations of large ground-water withdrawals

in the Coastal Plain area of Harford County for:

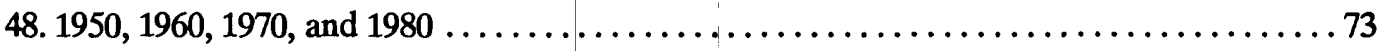

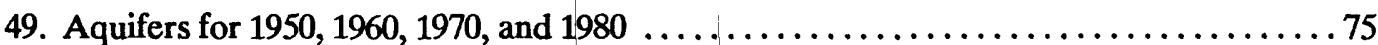

50-52. Graphs for Kent County showing:

50. Ground-water withdrawals by use from 1950 through $1980 \ldots \ldots \ldots \ldots \ldots \ldots \ldots$

51. Ground-water use and percentage for each type of use,

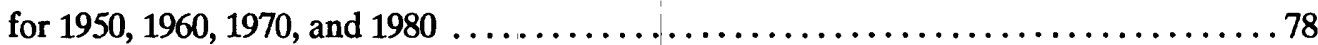

52. Large ground-water withdrawals by aquifers from 1950 through 1980 ............ 79

53-54. Maps showing locations of large ground-water withdrawals in Kent County for:

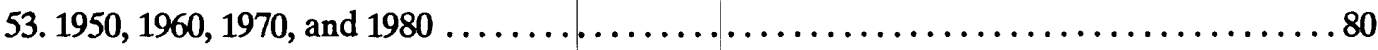

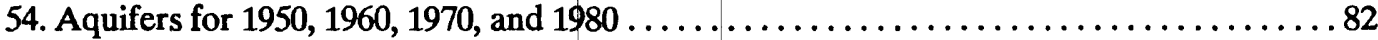




\section{ILLUSTRATIONS--Continued}

Figures

55-57. Graphs for the Coastal Plain area of Prince Georges County showing:

55. Ground-water withdrawals by use from 1950 through 1980 .84

56. Ground-water use and percentage for each type of use, for $1950,1960,1970$, and 1980 85

57. Large ground-water withdrawals by aquifers from 1940 through 1980 .86

58-59. Maps showing locations of large ground-water withdrawals

in the Coastal Plain area of Prince Georges County for:

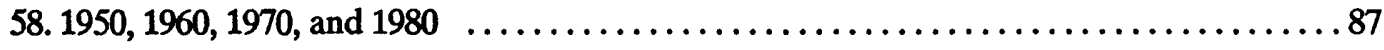

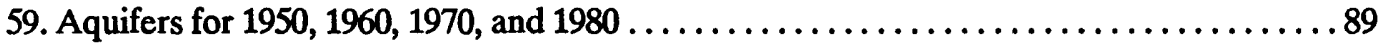

60-62. Graphs for Queen Annes County showing:

60. Ground-water withdrawals by use from 1950 through $1980 \ldots \ldots \ldots \ldots \ldots \ldots \ldots$. 91

61. Ground-water use and percentage for each type of use,

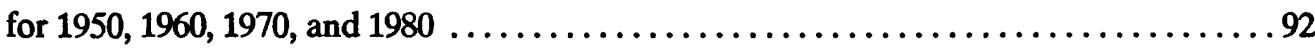

62. Large ground-water withdrawals by aquifers from 1950 through $1980 \ldots \ldots \ldots \ldots . .93$ 63-64. Maps showing locations of large ground-water withdrawals in Queen Annes County for:

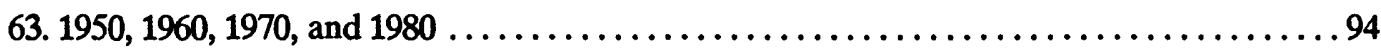

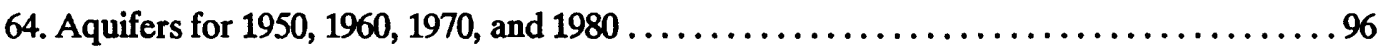

65-67. Graphs for St. Marys County showing:

65. Ground-water withdrawals by use from 1950 through $1980 \ldots \ldots \ldots \ldots \ldots \ldots$

66. Ground-water use and percentage for each type of use,

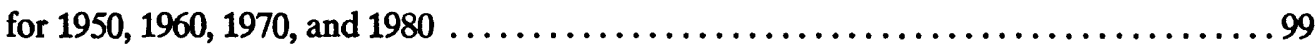

67. Large ground-water withdrawals by aquifers from 1950 through $1980 \ldots \ldots \ldots \ldots \ldots 100$ 68-69. Maps showing locations of large ground-water withdrawals in St. Marys County for:

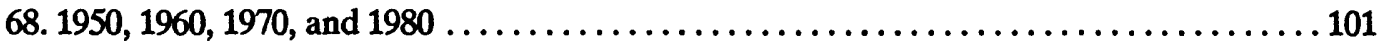

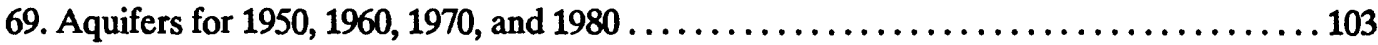

70-72. Graphs for Somerset County showing:

70. Ground-water withdrawals by use from 1950 through $1980 \ldots \ldots \ldots \ldots \ldots \ldots \ldots$

71. Ground-water use and percentage for each type of use,

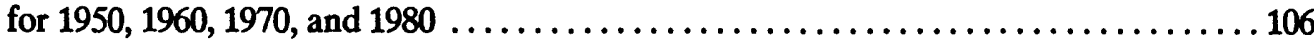

72. Large ground-water withdrawals by aquifers from 1950 through $1980 \ldots \ldots \ldots \ldots \ldots 107$ 


\section{ILLUSTRATIONS--Continued}

Figures

73-74. Maps showing locations of large ground-water withdrawals in Somerset County for:

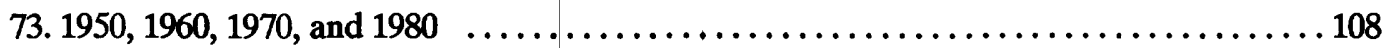

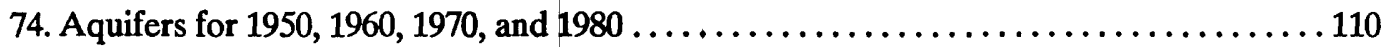

75-77. Graphs for Talbot County showing:

75. Ground-water withdrawals by use from 1950 through $1980 \ldots \ldots \ldots \ldots \ldots \ldots \ldots 112$

76. Ground-water use and percentage for each type of use,

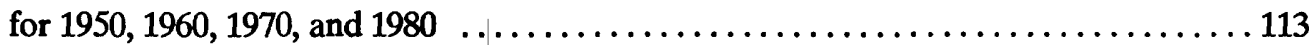

77. Large ground-water withdrawals by aquifers from 1950 through $1980 \ldots \ldots \ldots \ldots \ldots 114$

78-79. Maps showing locations of large ground-water withdrawals in Talbot County for:

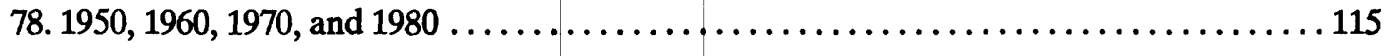

79. Aquifers for $1950,1960,1970$, and $1980 \ldots \ldots \ldots \ldots \ldots \ldots \ldots \ldots \ldots \ldots \ldots \ldots \ldots \ldots \ldots$

80-82. Graphs for Wicomico County showing:

80. Ground-water withdrawals by use from 1950 through $1980 \ldots \ldots \ldots \ldots \ldots \ldots \ldots \ldots$

81. Ground-water use and percentage for each type of use,

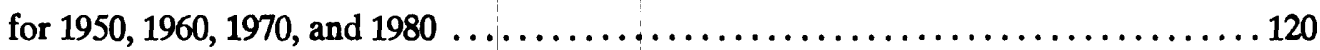

82. Large ground-water withdrawals by aquifers from 1950 through $1980 \ldots \ldots \ldots \ldots \ldots 121$

83-84. Maps showing locations of large ground-water withdrawals in Wicomico County for:

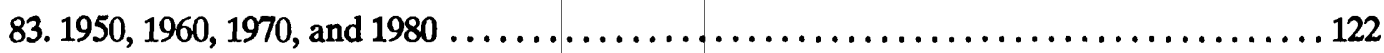

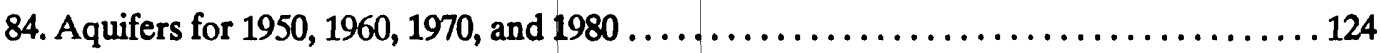

85-87. Graphs for Worcester County showing:

85 . Ground-water withdrawals by use from 1950 through $1980 \ldots \ldots \ldots \ldots \ldots \ldots \ldots$

86. Ground-water use and percentage for each type of use,

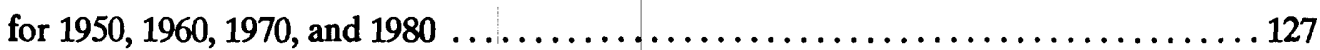

87. Large ground-water withdrawals by aquifers from 1950 through $1980 \ldots \ldots \ldots \ldots \ldots 128$

88-89. Maps showing locations of large ground-water withdrawals in Worcester County for:

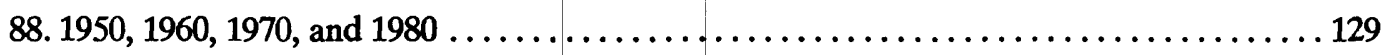

89. Aquifers for $1950,1960,1970$, and $1980 \ldots \ldots \ldots \ldots \ldots \ldots \ldots \ldots \ldots \ldots \ldots \ldots \ldots \ldots$ 


\section{TABLES}

Page

Table

1. Stratigraphic correlations of geologic and hydrologic units of the Coastal Plain of Maryland $\ldots \ldots \ldots 7$

2. Large ground-water users in Anne Arundel County in 1940, 1950, 1960, 1970, and 1980,

summarized by the Maryland Grid Coordinate System

3. Large ground-water users in the Coastal Plain area of Baltimore City

in $1930,1940,1950,1960,1970$, and 1980 , summarized by

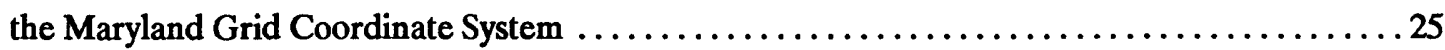

4. Large ground-water users in the Coastal Plain area of Baltimore County

in $1930,1940,1950,1960,1970$, and 1980 ,

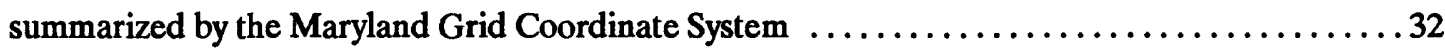

5. Large ground-water users in Calvert County in 1950, 1960, 1970, and 1980,

summarized by the Maryland Grid Coordinate System ................................. 39

6. Large ground-water users in Caroline County in 1950, 1960, 1970, and 1980,

summarized by the Maryland Grid Coordinate System $\ldots \ldots \ldots \ldots \ldots \ldots \ldots \ldots \ldots \ldots \ldots, \ldots$

7. Large ground-water users in the Coastal Plain area of Cecil County in 1950, 1960, 1970, and 1980,

summarized by the Maryland Grid Coordinate System. $\ldots \ldots \ldots \ldots \ldots \ldots \ldots \ldots \ldots \ldots \ldots, \ldots \ldots \ldots$

8. Large ground-water users in Charles County in 1950, 1960, 1970, and 1980,

summarized by the Maryland Grid Coordinate System. ........................60

9. Large ground-water users in Dorchester County in 1950, 1960, 1970, and 1980,

summarized by the Maryland Grid Coordinate System

10. Large ground-water users in the Coastal Plain area of Harford County

in 1950, 1960, 1970, and 1980, summarized by the Maryland Grid Coordinate System. . . . . . . 74

11. Large ground-water users in Kent County in 1950, 1960, 1970, and 1980,

summarized by the Maryland Grid Coordinate System $\ldots \ldots \ldots \ldots \ldots \ldots \ldots \ldots \ldots \ldots \ldots 1$

12. Large ground-water users in the Coastal Plain area of Prince Georges County

in 1950, 1960, 1970, and 1980,summarized by the Maryland Grid Coordinate System ........ 88

13. Large ground-water users in Queen Annes County in 1950, 1960, 1970, and 1980,

summarized by the Maryland Grid Coordinate System $\ldots \ldots \ldots \ldots \ldots \ldots \ldots \ldots \ldots \ldots \ldots$

14. Large ground-water users in St. Marys County in 1950, 1960, 1970, and 1980,

summarized by the Maryland Grid Coordinate System $\ldots \ldots \ldots \ldots \ldots \ldots \ldots \ldots \ldots \ldots . \ldots \ldots$

15. Large ground-water users in Somerset County in 1950, 1960, 1970, and 1980,

summarized by the Maryland Grid Coordinate System 


\section{TABLES--Continued}

Table

16. Large ground-water users in Talbot County in 1950, 1960, 1970, and 1980,

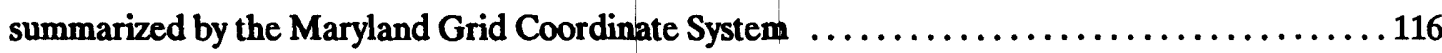

17. Large ground-water users in Wicomico County in 1950, 1960, 1970, and 1980,

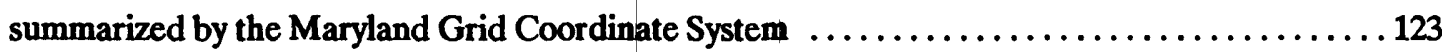

18. Large ground-water users in Worcester County in 1950, 1960, 1970, and 1980, summarized by the Maryland Grid Coordinate System 130

\section{CONVERSION FACTORS AND ABBREVIATIONS}

For the convenience of readers who may prefer to use metric (International System) units rather than the inch-pound units used in this report, values may be converted by using the following factors:

Multiply inch-pound unit
foot (ft)
gallon (gal)
gallon per day (gal/d)
million gallons (Mgal)
million gallons per day (Mgal/d)
million gallons per year(Mgal/yr)
mile (mi)
acre

\begin{tabular}{c|} 
By \\
0.3048 \\
3.785 \\
3.785 \\
3,785 \\
3,785 \\
3,785 \\
1.609 \\
0.4047
\end{tabular}

To obtain metric unit

meter (m)

liter (L)

liter per day $(\mathrm{L} / \mathrm{d})$

cubic meters $\left(\mathrm{m}^{3}\right)$

cubic meters per day $\left(\mathrm{m}^{3} / \mathrm{d}\right)$

cubic meters per year $\left(\mathrm{m}^{3} / \mathrm{yr}\right)$

kilometer (km)

hectare 


\title{
GROUND-WATER USE IN THE COASTAL PLAIN OF
}

\section{MARYLAND, 1900 - 1980}

\author{
by Judith $\mathrm{C}$. Wheeler and Franceska D. Wilde
}

ABSTRACT

\begin{abstract}
Historically, ground water has been the major source of supply for most users in the Coastal Plain of Maryland. This report presents ground-water withdrawal data from 1900 through 1980 for 16 counties and Baltimore City, that lie either partially or totally within the Coastal Plain physiographic province. These data were collected as part of the U.S. Geological Survey's Regional Aquifer Systems Analysis (RASA) study.

The data are discussed briefly and presented in graphs, tables, and maps. Five water-use categories that comprise the major demands on ground- water supplies are identified: domestic, military, public and private water suppliers, industrial (including commercial), and irrigation. Withdrawal data were obtained or estimated from diverse sources, including Maryland Water Resources Administration files, State and county reports and communication with public officials and individual owners. Aquifer designations of the source of the pumpage were determined by consulting published and unpublished geologic reports and were correlated with the 10-layer aquifer system established for the RASA study computer model.
\end{abstract}

The results of this research show that ground-water withdrawals increased from approximately 25 million gallons per day (Mgal/d) in 1900 to nearly $136 \mathrm{Mgal} / \mathrm{d}$ in 1980. Anne Arundel and Baltimore Counties and Baltimore City had the greatest withdrawals, more than $5 \mathrm{Mgal} / \mathrm{d}$, for most of the 80 -year period.

Domestic and industrial/commercial uses comprised the largest withdrawals from 1900 through 1965. For most of the next 15 years, to 1980, water suppliers constituted the greatest demand on ground-water supplies. Large withdrawals for irrigation in the Coastal Plain began in the late 1950's and were primarily centered in Caroline, Dorchester, Queen Annes, and Wicomico Counties.

The surficial aquifer was the most heavily used source of ground water for domestic use; however, it also provided adequate quantities to a few large users (those withdrawing $0.01 \mathrm{Mgal} / \mathrm{d}$ or more). The deeper Patapsco and Patuxent aquifers supplied the most water to large users during the 80 -year period, mainly for industrial/commercial use.

\section{INTRODUCTION}

The U.S. Geological Survey has conducted Regional Aquifer Systems Analysis (RASA) studies throughout the nation. One of these RASA studies analyzed the northern Atlantic Coastal Plain aquifer system, which encompasses a six-state area stretching from Long Island to North Carolina. The RASA study included development of a digital model to simulate the properties of the Coastal Plain aquifer system and the effect of pumpage on that system. The data presented here were collected as part of the P.ASA study, and were used for the calibration and verification of the model.

This report is designed to provide public officials and interested persons a compendium of historical ground-water-use data for the Coastal Plain of Maryland. It was prepared in cooperation with the 
Maryland Geological Survey and the Maryland Water Resources Administration. Financial support was privided by the Maryland Geological Survey and the
RASA and National Water Use Data programs of the U.S. Geological Survey.

\section{PURPOSE AND SCOPE}

This report presents ground-water withdrawal data for the 16 counties and part of Baltimore City that lie within the Coastal Plain physiographic province (fig. 1). The data are summarized for each county and Baltimore City, as well as for the Coastal Plain region as a whole, and are presented in graphs, tables, and maps. Ground-water withdrawal data have been categorized by water user, aquifer used, and quantity withdrawn. The compiled data span the period 1900 through 1980.

\section{DATA COLLECTION AND ESTIMATION OF WATER USE}

The categories of water use discussed in this report are:

1.Domestic.--Includes self-supplied individual houses and general farm use, such as livestock watering.

2. Military.--Includes Federal military institutions and installations only.

3. Water suppliers.--Includes municipality, county and town systems, hospitals, institutions, schools, trailer parks, and private water companies.

4. Industrial/commercial.--Includes manufacturing industries, utilities (including electric power), fish hatcheries, laundries, theaters, hotels, motels, government-operated research centers, restaurants, and mining (coal, quarry, sand, and gravel) operations.

5. Irrigation.--Includes water used for farmland, nursery crops, and golf courses.

Although this report presents withdrawal data beginning with 1900 , few records of actual pumpage were available for individual users prior to the 1960's. Withdrawals between 1900 and 1969 were averaged for each decade in million gallons per day (Mgal/d). Many of these earlier data were estimated based on current withdrawals, population trends, written and oral communication with water users, and amounts given in various reports for a particular time span or year. Most of the graphs for individual counties begin with 1950; however, if enough substantial earlier records were available, graphs were plotted to include these data.

Much of the withdrawal information for large users (those who individually withdraw $0.01 \mathrm{Mgal} / \mathrm{d}$ or more) was obtained from the Maryland Water Resources Administration. This agency requires users of $0.01 \mathrm{Mgal} / \mathrm{d}$ or more to report monthly pumpage. These data were then tabulated and stored on computer tapes beginning with the earliest known pumpage. Programs were designed to generate graphs and tables from these tapes for this report. Other sources of water-use data include Maryland Geological Survey Bulletins and Reports of Investigations, Basic Data Reports, county water and sewerage plans, and miscellaneous county reports.

Domestic water use was estimated by taking the total county population (Maryland Dept. of State Planning, 1981) for each year selected and subtracting the estimated population served by municipalities and private water companies (Maryland Dept. of State Planning, 1981, and Maryland Dept. of Natural Resources, 1983). The difference was then multiplied by 75 gallons per person per day (U.S. Environmental Protection Agency, 1973). The determination of water quantities used for irrigation was based on the estimated number of acres irrigated by ground water (U.S. Dept. of Commerce, 1961, 1967, 1972, 1977, and 1981a; and Carr, 1975, 1977, and 1980) and an assumed average application rate of $0.6 \mathrm{ft}$ of water per year (Herring, 1983). Irrigation data for counties withdrawing an average of less than $0.1 \mathrm{Mgal} / \mathrm{d}$ for this use over the 80-year period were not included in this report.

Pumpage sites were located on county maps using the Maryland Grid Coordinate System method. In this system, a point is designated by actual distances in feet from two imaginary lines--one running east and west, and the other north and south through a point of origin. The origin of the Maryland Grid Coordinate System is fixed at a point southwest of the State, so that all coordinates are to the east and north of it. The coordinates of this point are NO (zero) E O (zero). For mapping purposes, horizontal and vertical grid lines were estabhished from this point at intervals of $50,000 \mathrm{ft}$ east and north of the origin (Maryland Department of State Planning, 1978).

Aquifer designations were assigned by consulting published and unpublished geologic logs and maps, State and county reports, and correlating depth of screened intervals of wells with the isopach maps constructed by RASA hydrogeologists. 


\section{FORMAT}

The water-use data presented here are described in individual sections for each county and Baltimore City, preceded by a section for the entire Coastal Plain. The data are depicted in graphs, tables, and maps.
Ground-water appropriation permit numbers given in the tables are issued by the Maryland Water Resources Administration and are presented here for the convenience of any further detailed research.

\section{LOCATION AND EXTENT OF STUDY AREA}

This report presents data on ground-water use for the part of Maryland that lies within the Coastal Plain physiographic province (fig. 1A). The Coastal Plain province of Maryland covers an area of 8,240 square miles, or approximately one-half of the total area of the State (Knopf, 1929).

The study area is bounded on the east by Delaware and the Atlantic Ocean; on the south by the Potomac River, the Chesapeake Bay, and Virginia; on the west by the Potomac River; and to the west and north by the Fall Line (the contact between the Coastal Plain and Piedmont physiographic provinces). It is widely dissected by the Chesapeake Bay.
Eighteen Maryland counties lie entirely or partially within the Coastal Plain province: Anne Arundel, Baltimore, Calvert, Caroline, Cecil, Charles, Dorchester, Harford, Howard, Kent, Montgomery, Prince Georges, Queen Annes, St. Marys, Somerset, Talbot, Wicomico, and Worcester Counties. The six counties that lie partially within the Coastal Plain include most of Prince Georges County, nearly half of Cecil County, approximately one-fifth of Baltimore and Harford Counties, and less than one-eighth of Howard and Montgomery Counties. About half of Baltimore City lies in the Coastal Plain. Ground-water use in the Coastal Plain of Howard and Montgomery Counties was not significant enough for the period of study to include in this report.

\section{HYDROGEOLOGIC SETTING}

This discussion presents a brief background of the hydrogeology relevant to the material covered in this report. However, for an in-depth treatment that defines and interprets the hydrogeology of the study area, the reader is referred to a publication prepared as part of the RASA study entitled Hydrogeologic Framework of the Coastal Plain in Maryland, Delaware, and the District of Columbia (D. Vroblesky and W. Fleck, U.S. Geological Survey, written commun., 1987).

Maryland covers an area of diverse geology that is divided into five physiographic provinces (regions of distinctive geomorphology) (fig. 1A). The study area comprises the southeastern physiographic province, known as the Coastal Plain province (fig. 1B). In Maryland, the Coastal Plain province is bounded on the west by its contact with the crystalline rocks of the Piedmont province. The zone of this contact is characterized by numerous waterfalls, and thus is commonly known as the Fall Line.

The Coastal Plain is underlain by a wedge-shaped sequence of stratified sediments that dip gently to the southeast and range in thickness from zero at the Fall Line to nearly $8,000 \mathrm{ft}$ at Ocean City, Maryland (fig. 2). This body of mostly unconsolidated gravel, sand, silt, and clay comprises a sequence of stratigraphic units that includes Quaternary deposits at the top of the geologic section, underlain by deposits of Tertiary and Cretaceous age, respectively. The bottommost strata are Lower Cretaceous deposits that lie unconformably on an older complex of basement rocks, which are of Jurassic (?) to Precambrian age (table 1).

As part of the RASA study, the sequence of deposits were divided into 10 regional hydrogeologic units. Each of these units comprise an aquifer, that is, a geologic formation, group of formations or part of a formation that contains sufficient saturated permeable material to yield significant quantities of water to wells and springs (Lohman and others, 1972). Each aquifer is characterized by distinctive hydrogeologic properties and separated by confining units or strata of very low hydraulic conductivity relative to that of the aquifer. The topmost aquifers differ hydrologically from deeper aquifers in that they are not overlain by a confining unit. As a consequence of being unconfined, fluid pressure at the water-table surface is exactly equal to that of the atmosphere. Unconfined aquifers are also called surficial aquifers or water-table aquifers. The term "surficial aquifer" is used in this report, although commonly used local designations are also noted. In the confined aquifers, water is stored under artesian conditions (hydrostatic pressure is greater than atmospheric pressure). Although the water level in a well fully penetrat- 

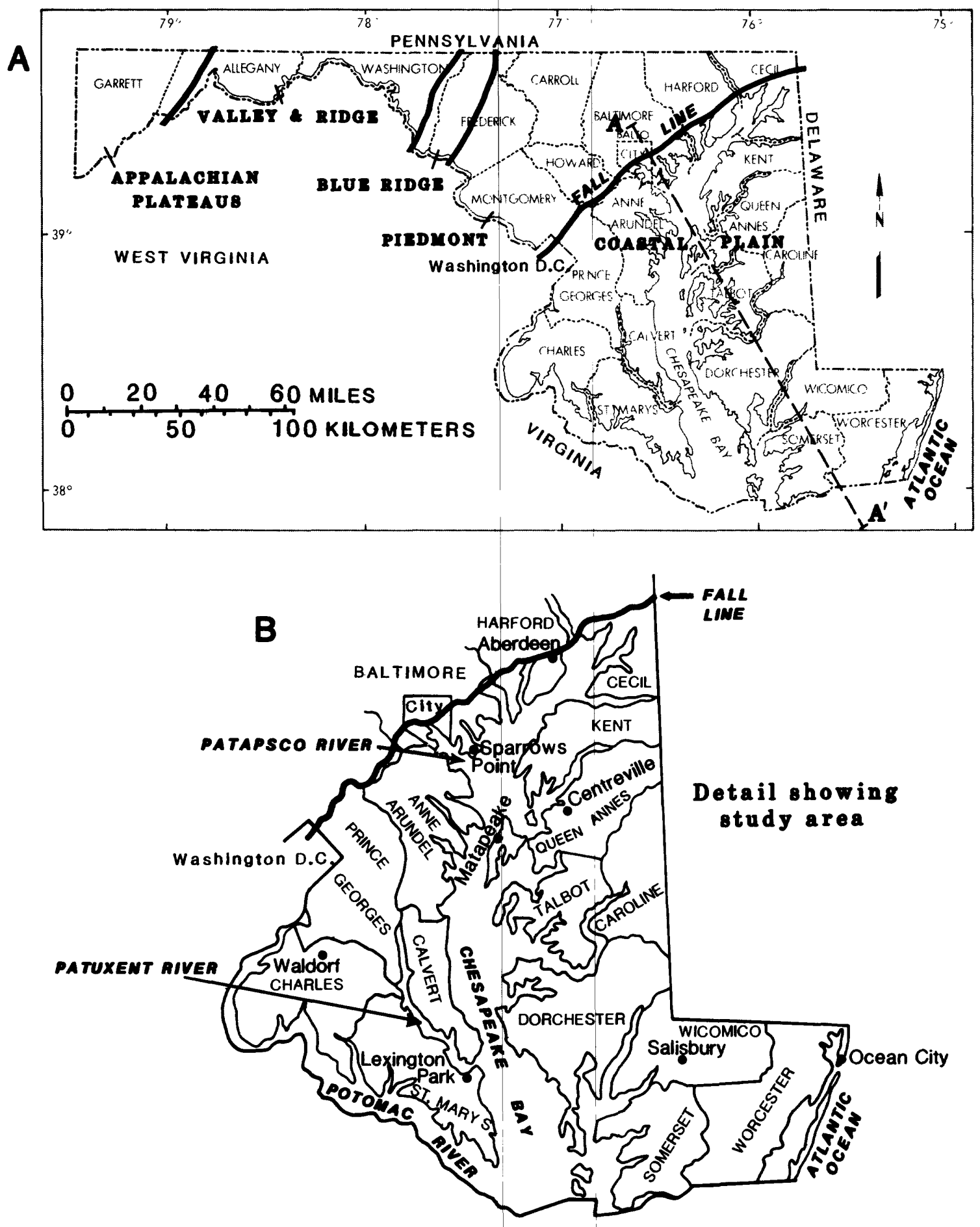

Figure 1.--Location and extent of the Coastal Plain in Maryland.

A. Boundaries of physiographic provinces.

B. Location and extent of study area. 
A

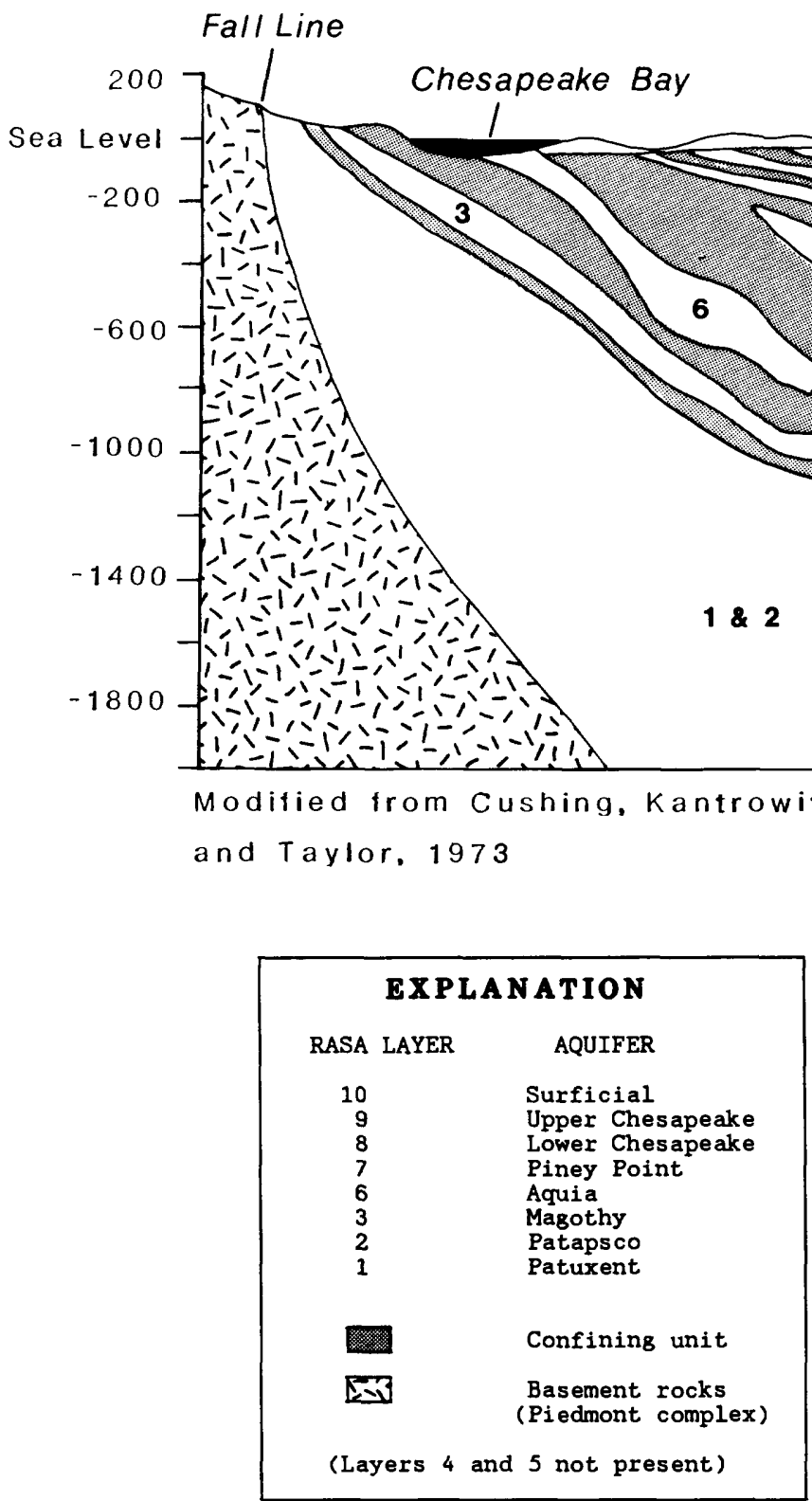

Figure 2.--Hydrogeologic section $A-A^{\prime}$ through the study area. 
ing a confined aquifer will rise above the aquifer surface at the point of penetration, water levels in wells that penetrate a surficial aquifer close to the water table define the top of the saturated zone.

Figure 2 is a hydrogeologic section depicting the stratigraphic relationship between aquifer units. All aquifer units are not regionally extensive; those units important as aquifers in one part of the study area may not be present in another. For example, the aquifer in sediments of Paleocene age (table 1) is not known to exist north of St. Marys and Somerset Counties and does not appear in the cross section. Consequently, the Aquia aquifer rests directly on the confining unit above the Severn aquifer in most of the study area. (The Severn aquifer is also referred to as the Monmouth aquifer by the Maryland Geological Survey.) Where the aquifer in sediments of Paleocene age does exist, it apparently rests directly on the Magothy Formation, indicating that the Severn and Matawan Formations are missing.
The presence and importance of a given aquifer unit is noted in each county section and in table 1 under the description of hydrologic characteristics. However, the term surficial aquifer is used in this report for four local aquifers commonly referred to as Quaternary, Pleistocene, Columbia, and Talbot aquifers (see footnote 2 of table 1). Where appropriate, the local term is identified parenthetically. Local terminology is used in tables and illustrations. Moreover, in this report, the Choptank aquifer and Raritan aquifer (obsolete usage) are referred to as the lower Chesapeake aquifer and Patapsco aquifer, respectively. Sediments formerly included in the Raritan Formation are now assigned to the upper part of the underlying Patapsco Formation (C. Davidson, U.S. Geological Survey, written commun., 1987). The correlation of stratigraphic divisions formally recognized by the U.S. Geological Survey to local aquifers as well as to regional hydrogeologic units used in the RASA study model are given in table 1.

\section{ACKNOWLEDGMENTS}

Numerous Federal, State, and county agencies, private corporations, and businesses furnished wateruse data for this report. Personnel of the Maryland
Water Resources Administration provided valuable assistance with the interpretation and verification of pumpage reports submitted to the agency.

\section{GROUND-WATER USE IN THE COASTAL PLAIN OF MARYLAND}

Historically, ground water has been the major source for domestic, military, water supplier, industrial/commercial, and irrigation uses in the Coastal Plain of Maryland. Ground-water withdrawals by use from 1900 through 1980 are shown in figure 3. In 1900, the amount of ground water withdrawn was approximately $25 \mathrm{Mgal} / \mathrm{d}$ compared to withdrawals of nearly $136 \mathrm{Mgal} / \mathrm{d}$ in 1980 . This represents an increase of 438 percent over the 80 -year period.

Since 1900, water use in the Coastal Plain increased in all categories. Estimated domestic water use was about $14.0 \mathrm{Mgal} / \mathrm{d}$ in 1900 , but increased to about 35.0 $\mathrm{Mgal} / \mathrm{d}$ in 1980 . Water withdrawn for use in military facilities was approximately $1.0 \mathrm{Mgal} / \mathrm{d}$ in 1900 . Withdrawals increased from about $2 \mathrm{Mgal} / \mathrm{d}$ in 1942 to nearly $6.0 \mathrm{Mgal} / \mathrm{d}$ in 1970 . By 1980 , however, military pumpage declined to about $4 \mathrm{Mgal} / \mathrm{d}$. Water withdrawn by water suppliers increased from about $3.0 \mathrm{Mgal} / \mathrm{d}$ in 1900 to approximately $56 \mathrm{Mgal} / \mathrm{d}$ in 1980 , with the largest increases occurring between 1950 and 1980. Withdrawals for the industrial/commercial category were approximately $8.0 \mathrm{Mgal} / \mathrm{d}$ in 1900 and increased over the following years to a peak of about $49.0 \mathrm{Mgal} / \mathrm{d}$ in 1942. After 1942, this pumpage began to decline and by the late 1940 's, about $31.0 \mathrm{Mgal} / \mathrm{d}$ was being withdrawn. In 1950, industrial/commercial pumpage increased again to nearly $39.0 \mathrm{Mgal} / \mathrm{d}$, and, over the next 30 years, showed a gradual decline to about $25.0 \mathrm{Mgal} / \mathrm{d}$ in 1980.

Large-scale irrigation is a relatively recent type of water use in the Maryland Coastal Plain. Until the late 1950's, most irrigation was in the central and western counties of the State. However, increased urban development in these counties caused a major shift of vegetable growing and attendant irrigation to the Eastern Shore of Maryland where land was less expensive and growing conditions were more favorable (Brodie and others, 1984). By 1969, 73 percent of the acres irrigated were located on the Eastern Shore, and by 1975 the percentage had increased to 85 percent. Figure 3 shows that, in 1960, approximately $2.0 \mathrm{Mgal} / \mathrm{d}$ were withdrawn for irrigation in the Coastal Plain. Use continued to increase so that by 1980 , withdrawals were nearly $12.0 \mathrm{Mgal} / \mathrm{d}$. Figure 4 compares percentage of ground-water withdrawals by type of use for the beginning year of each decade from 1900 through 1980. 


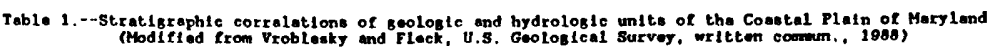

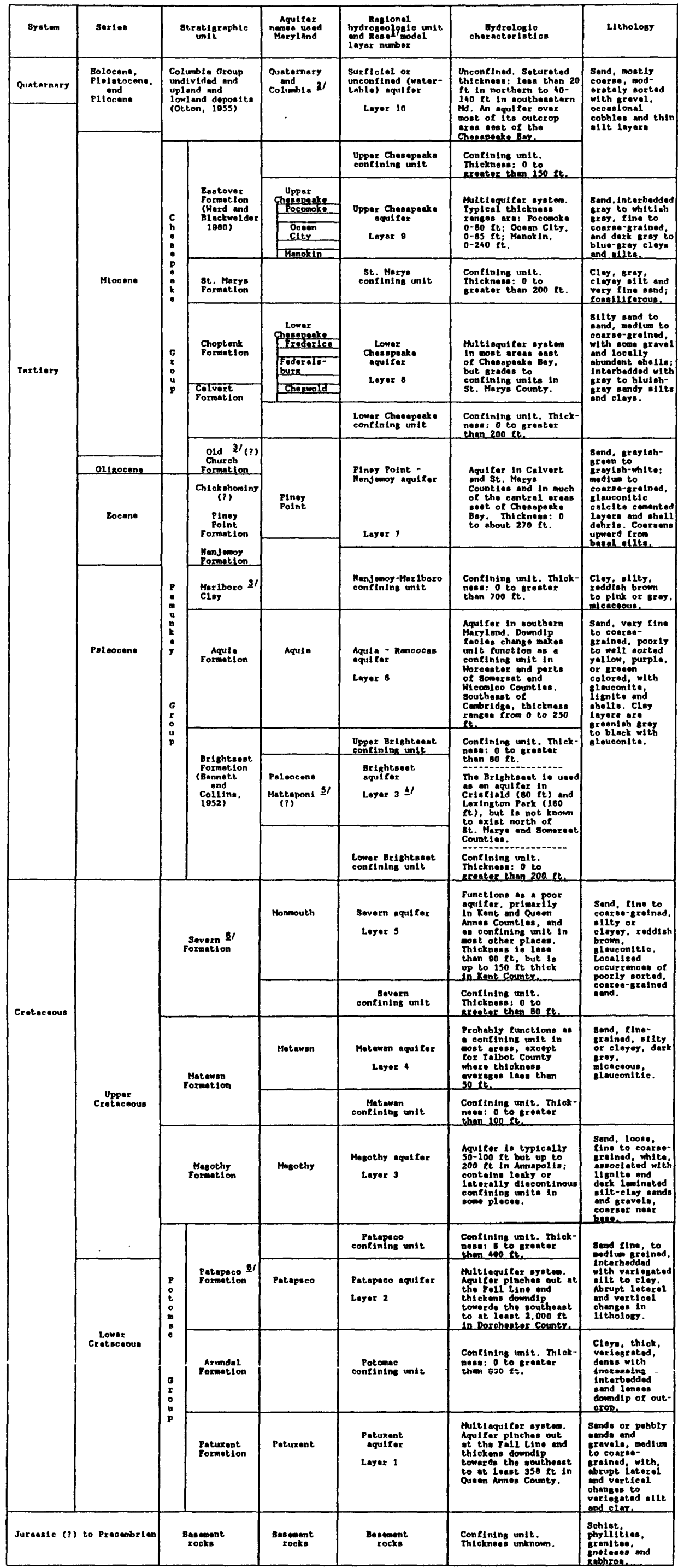

1/Roestonal Aqul for Byotoms Analysts (RASA) Btudy.

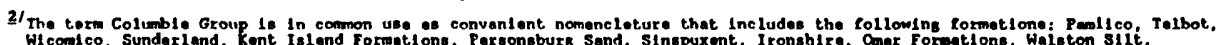
Baguardem S 18 Hard,

I/vrohleoky and Fleck, (B.S. Goologleal survay, writlan commun., 1988),

2' Manneon and wileon, 1084.

S/ Also known os the Monmouth Formation In Marylond. 


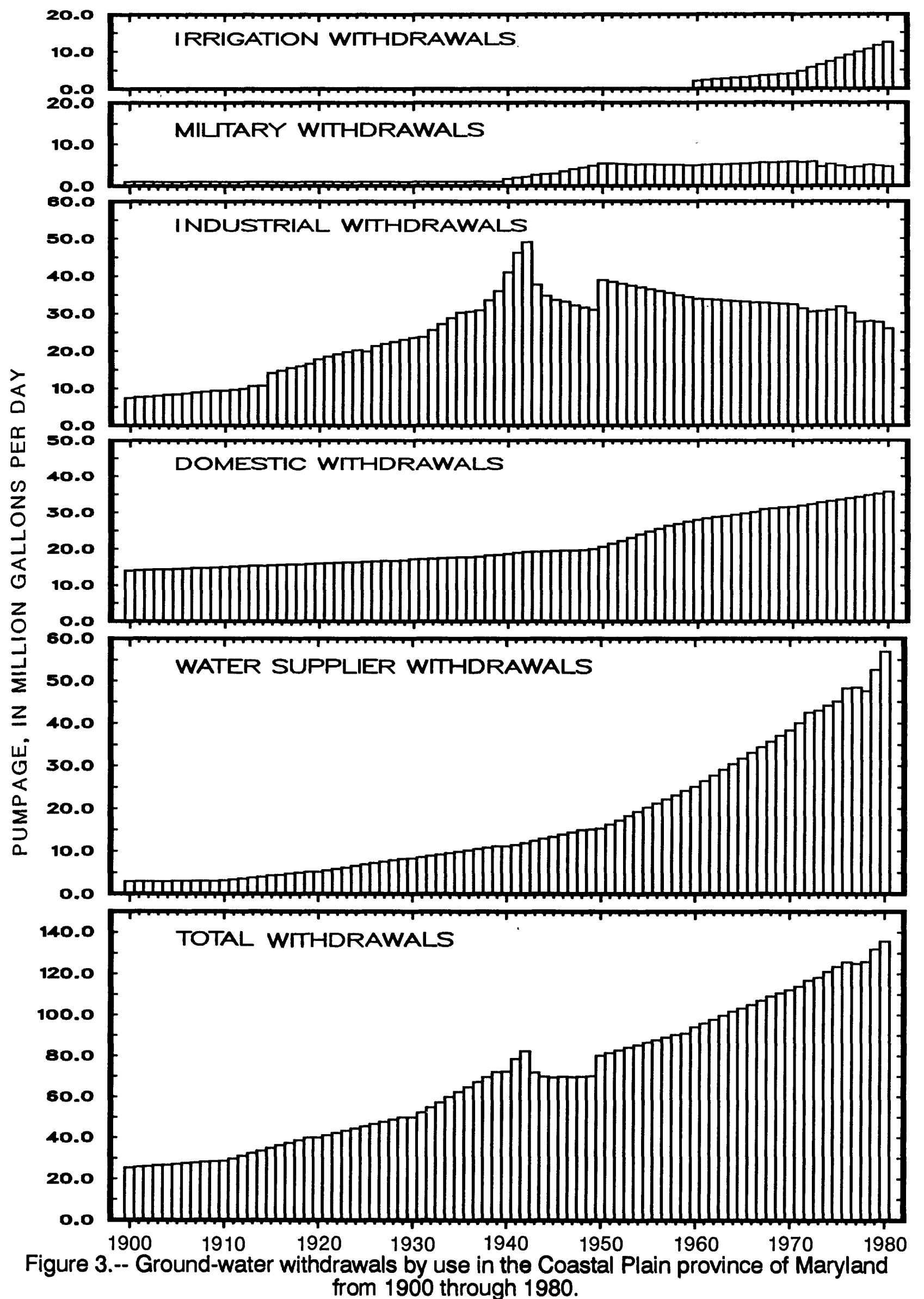




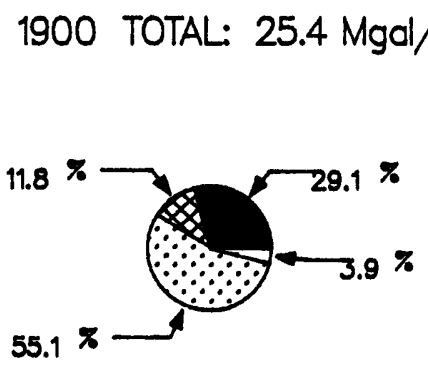

1930 TOTAL: $50.0 \mathrm{Mgal} / \mathrm{d}$

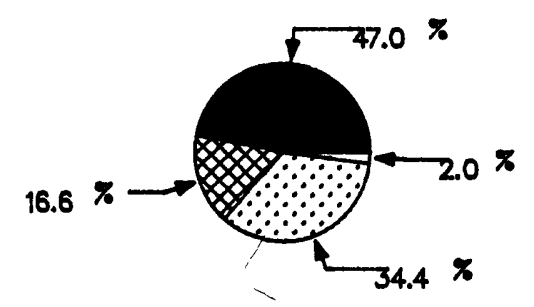

1950 TOTAL: $80.3 \mathrm{Mgal} / \mathrm{d}$

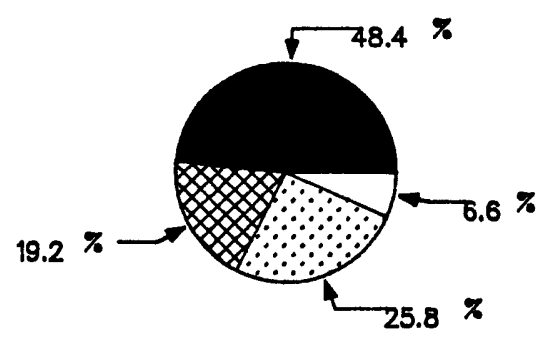

1970 TOTAL: $112.3 \mathrm{Mgal} / \mathrm{d}$

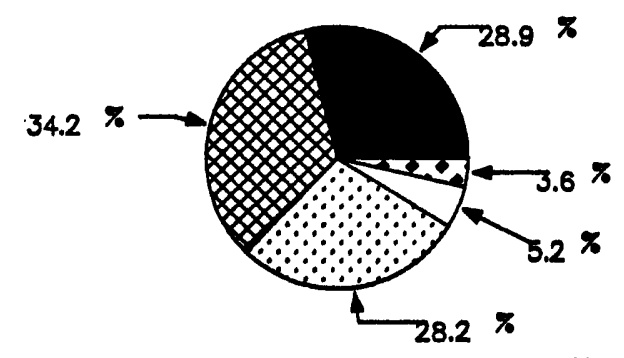

$28.2 \%$

EXPLANATION

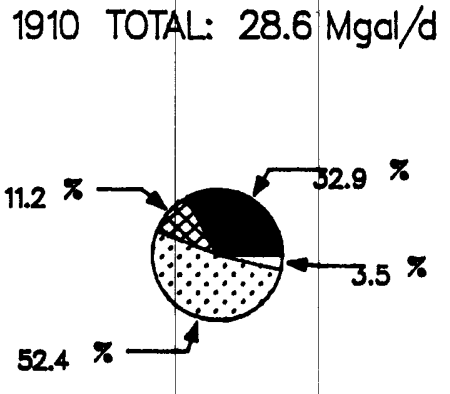

1920 TOTAL: $40.0 \mathrm{Mgal} / \mathrm{d}$

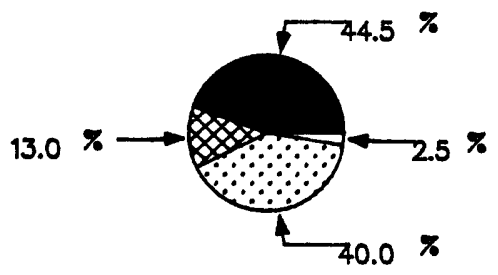

1940 TOTAL: $72.4 \mathrm{Mgal} / \mathrm{d}$

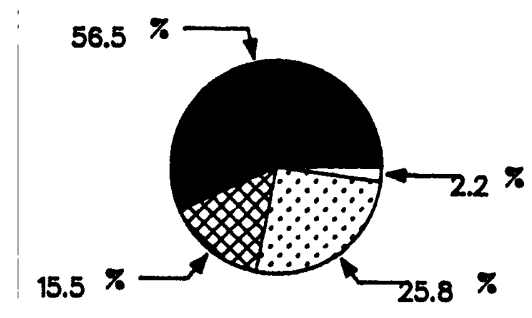

1960 TOTAL: $94.3 \mathrm{Mgal} / \mathrm{d}$

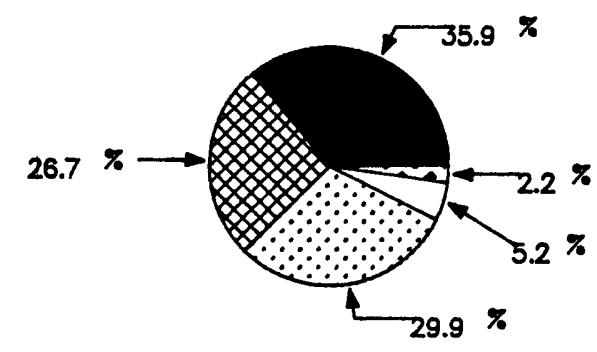

1980 TOTAL: $135.7 \mathrm{Mgal} / \mathrm{d}$

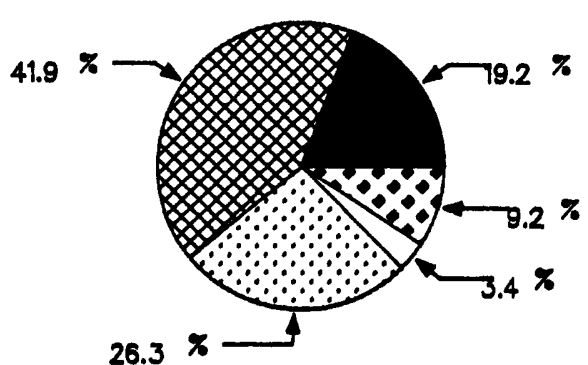

INDUSTRIAL/COMMERCIAL

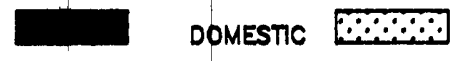

WATER SUPPUER MILTARY

IRRIGATION

0.00

Figure 4.--Ground-water use in the Maryland Coastal Plain and percentage for each type of use, for decade years 1900 through 1980. 
In 1900, much of the ground-water withdrawals in the Coastal Plain came from the surficial aquifer. This aquifer continued to supply not only the water needs of domestic use, but also the large quantities needed by several industries and water suppliers. In areas where the surficial aquifers were not available or suitable for use by large users, deeper aquifers were utilized including, in descending order, the Pocomoke and Manokin aquifers (equivalent to the upper Chesapeake aquifer), lower Chesapeake, Piney Point, Aquia, Severn, and Magothy aquifers, and the Patapsco and Patuxent aquifers in the Potomac Group undivided.

Large ground-water withdrawals from the principal aquifers of the Coastal Plain of Maryland from 1900 through 1980 are shown in figure 5.

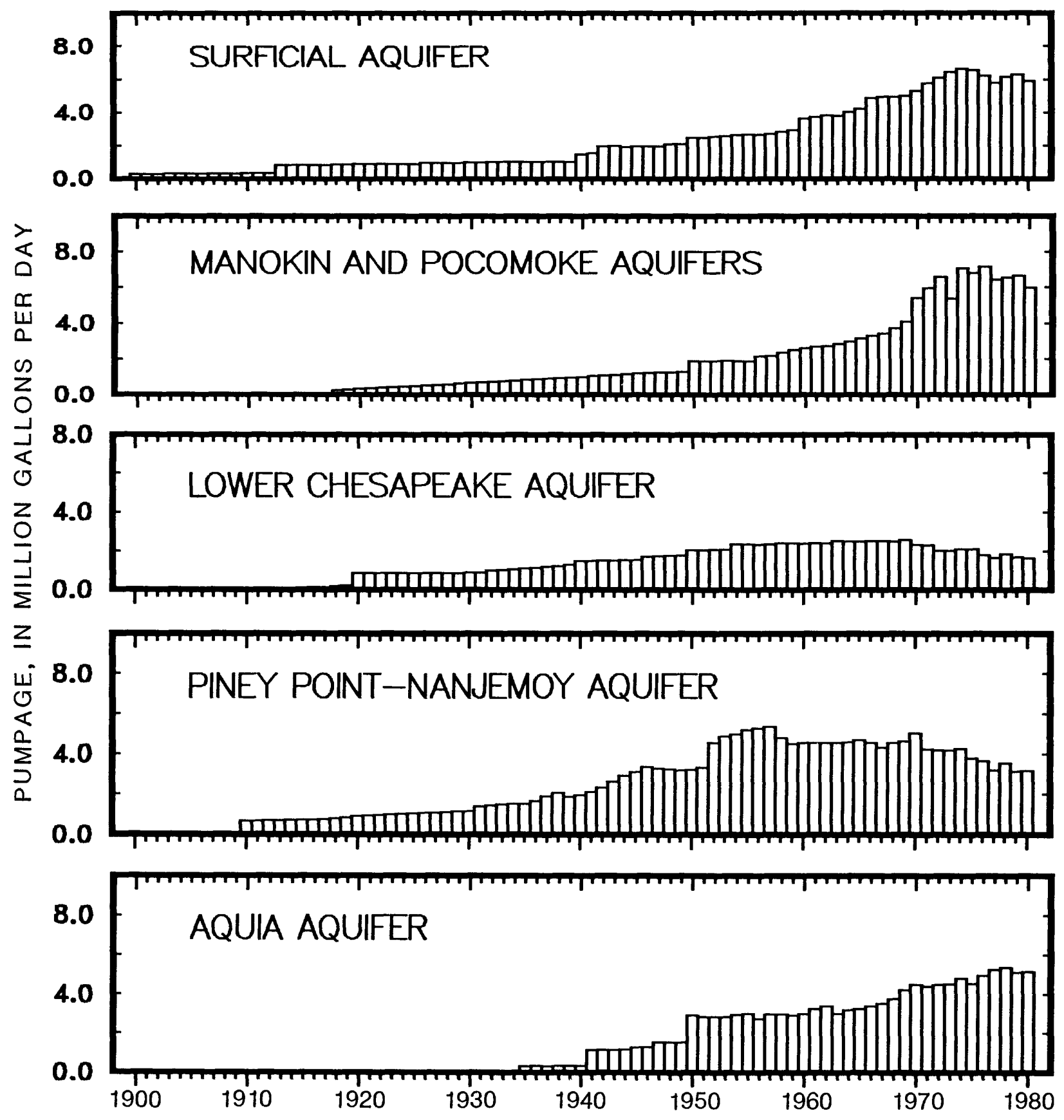

Figure 5.--Large ground-water withdrawals by aquifers in the Maryland Coastal Plain from 1900 through 1980. 


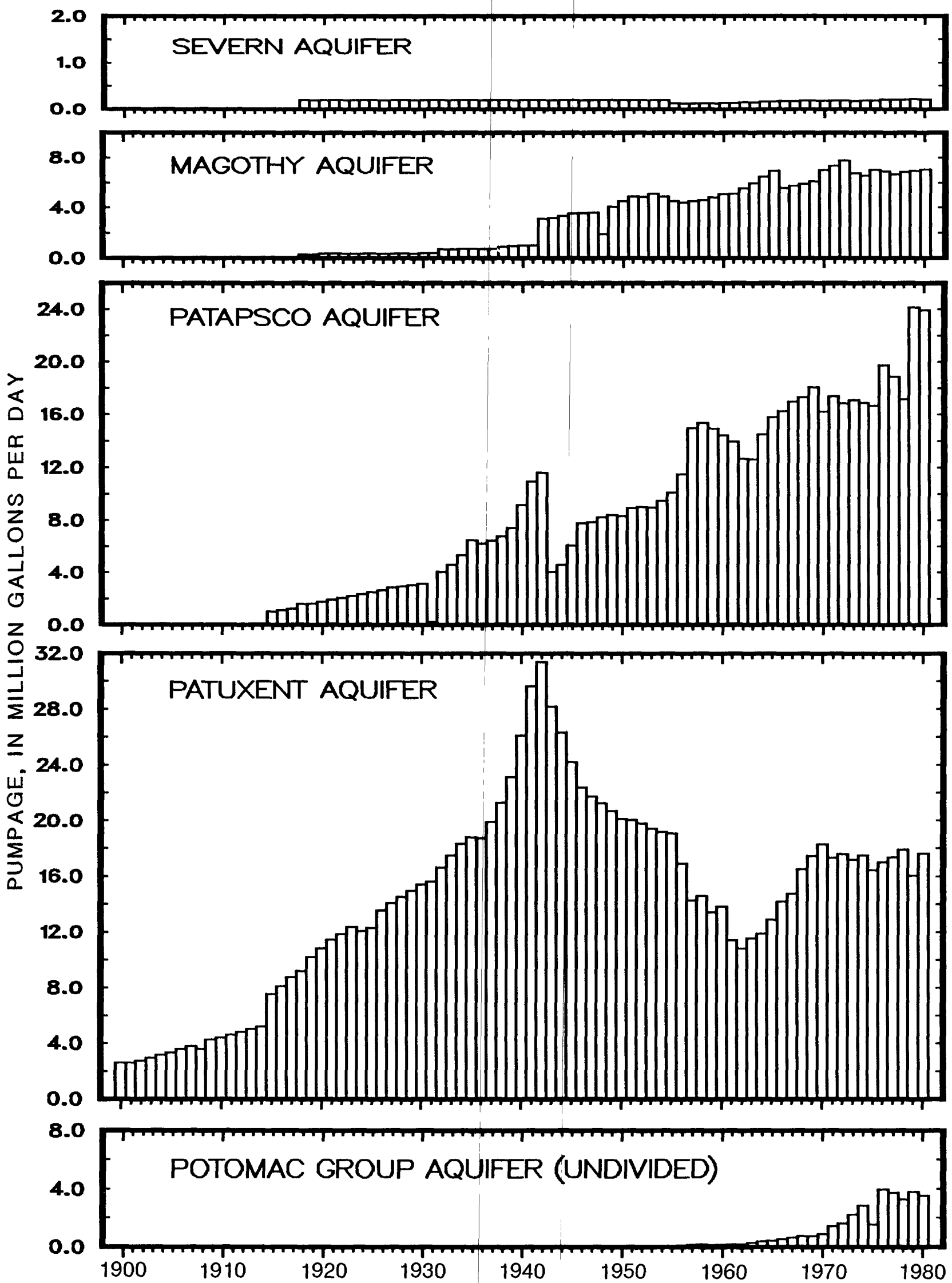

Figure 5.--Large ground-water withdrawals by aquifers in the Maryland Coastal Plain from 1900 through 1980 --Continued. 


\section{ANNE ARUNDEL COUNTY}

Ground-water use in Anne Arundel County from 1940 through 1980 is shown in figure 6. In 1940, the anount of ground water withdrawn was approximately $7.5 \mathrm{Mgal} / \mathrm{d}$ compared to withdrawals of nearly 41.0 $\mathrm{Mgal} / \mathrm{d}$ in 1980. This represents an increase of more than 400 percent in the four decades.

Since 1940, water use in Anne Arundel County has increased in all categories. Figure 6 indicates that in 1940 the largest use of ground water in the county was domestic, with withdrawals of about $3.8 \mathrm{Mgal} / \mathrm{d}$. By 1980 , this use increased to approximately $9.1 \mathrm{Mgal} / \mathrm{d}$. Withdrawals for military use were about $1.0 \mathrm{Mgal} / \mathrm{d}$ in 1940 and increased to about $2.4 \mathrm{Mgal} / \mathrm{d}$ in 1980 . Water suppliers withdrew about $2.7 \mathrm{Mgal} / \mathrm{d}$ in 1940 and continued to increase withdrawals through 1980 to nearly $25.0 \mathrm{Mgal} / \mathrm{d}$, becoming the largest users of ground water in the county. Industrial/commercial use was less than $0.05 \mathrm{Mgal} / \mathrm{d}$ in 1940 , but increased to about $4.5 \mathrm{Mgal} / \mathrm{d}$ by 1980 . See appendix for ground-water withdrawal data for each large user: User's name, appropriation permit number, the source aquifer, location on the Maryland Grid Coordinate System, average daily pumpage, and year pumping began.

The percentages of total amount of ground water withdrawn for domestic, military, water suppliers, and industrial/commercial users for 1940, 1950, 1960, 1970, and 1980 are shown in figure 7. The figure indicates a decline in the percentage for domestic use from about 50 percent in 1940 to 22 percent in 1980, and an increase in the percentage of use by water suppliers from 35.8 percent in 1940 to 61 percent in 1980. This is explained for the most part, by the increase in the percentage of the population served by central watersupply systems, either public or private, rather than by individual wells. The percentage of use for the military dropped from 13 percent in 1940 to 8 percent in 1960, and remained about the same for 1970 and 1980. The percentage for industrial/commercial use remained relatively constant for each of the years shown.

\section{Major Aquifers}

Many domestic withdrawals in Anne Arundel County were from shallow wells (from about 15 to $50 \mathrm{ft}$ deep) tapping the surficial aquifer. Deeper aquifers, including the Aquia, Magothy, Patapsco, and Patuxent, were more widely used by large users. Large user withdrawals by aquifer from 1940 to 1980 are shown in figure 8.
Pumpage from the Aquia aquifer remained relatively constant at about $0.03 \mathrm{Mgal} / \mathrm{d}$ from 1940 through 1954 , then steadily increased to about $0.3 \mathrm{Mgal} / \mathrm{d}$ in 1980. From 1940 to the early 1950's, the Magothy aquifer was the major source of water in the county. For most of the 40 years shown, withdrawals from the Magothy were between 2.0 and $4.0 \mathrm{Mgal} / \mathrm{d}$. Withdrawals from the Patapsco were about $1.1 \mathrm{Mgal} / \mathrm{d}$ in 1940; by the mid-1960's, withdrawals were close to $10.0 \mathrm{Mgal} / \mathrm{d}$. Pumpage from the Patapsco aquifer continued to increase, and by 1980 , approximately 20.0 $\mathrm{Mgal} / \mathrm{d}$ were withdrawn. Pumpage from the Patuxent aquifer began in 1951 at about $0.03 \mathrm{Mgal} / \mathrm{d}$ and increased significantly the following years. By 1980, nearly $6.0 \mathrm{Mgal} / \mathrm{d}$ were pumped from the Patuxent aquifer.

\section{Locations of Large Ground-Water Withdrawals}

The locations of withdrawals by large users in Anne Arundel County for 1940, 1950, 1960, 1970, and 1980 are shown in figure 9. Table 2 presents water-use data for the large users located within particular grid blocks for the year indicated on the map.

In 1940, the areas of heaviest pumpage were located for the most part, in the east-central portion of the county, mainly around the Annapolis area. Comparison of the maps shows a substantial increase in large user withdrawals in northern and southern Anne Arundel County from 1940 to 1980.

The locations of withdrawals from individual aquifers supplying the large users in Anne Arundel County (described in table 2 and fig. 9) are shown in figure 10. In 1940,1950, 1960, and 1970, the Aquia aquifer supplied most of the water in the southern part of the county. By 1980, the Magothy aquifer was supplying some of the water to large users in the southwestern section. The Magothy, however, was more extensively used in the central part of the county during the period of record shown in figure 10 .

The Patapsco aquifer was used mostly in the northern part of the county; the number of large users relying on it increased between 1940 and 1980. Withdrawals from the Patuxent aquifer were very limited in 1950. By 1960, however, use of the aquifer extended to a few scattered areas in the northern and north-central part of the county and continued to increase through 1980. 


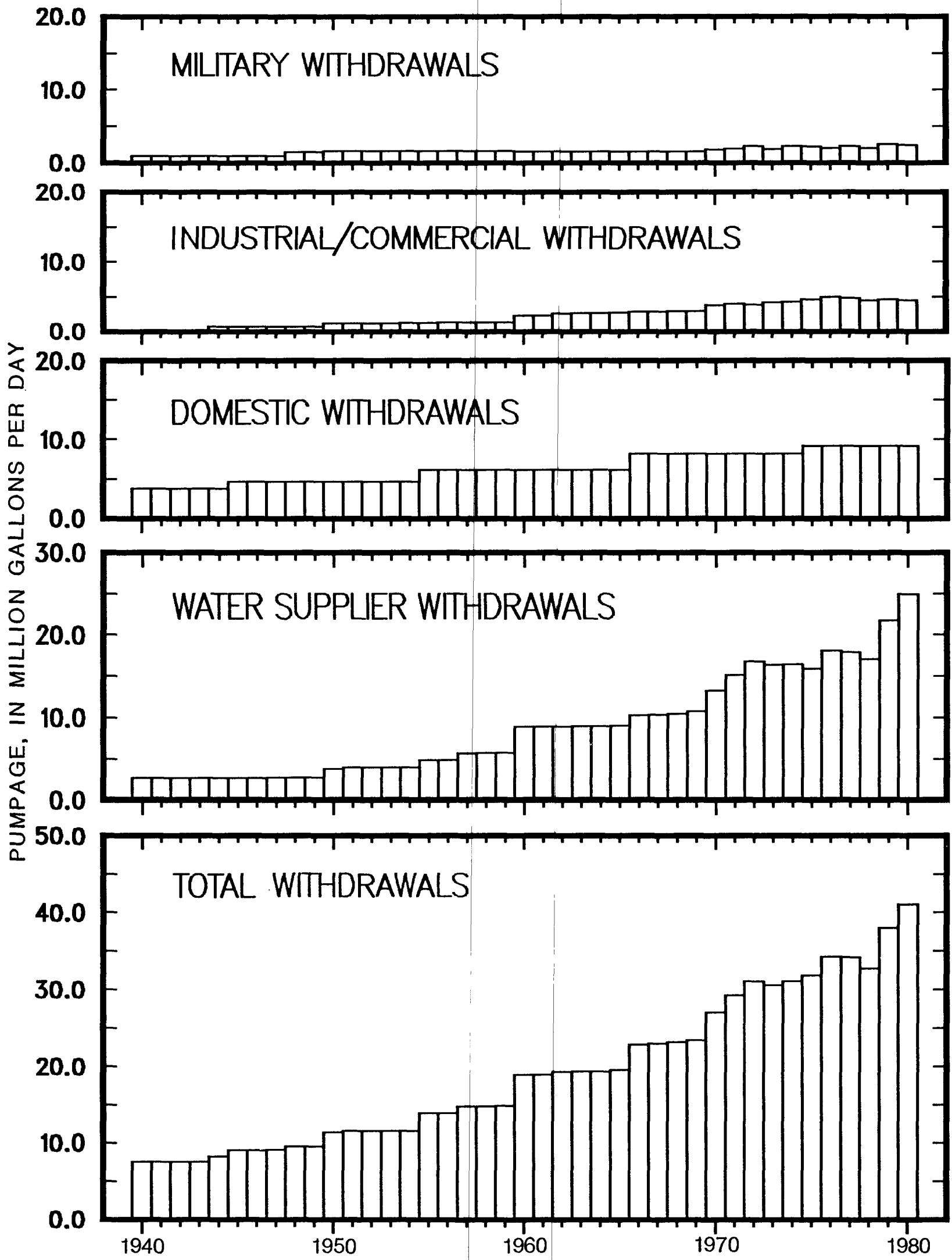

Figure 6.--Ground-water withdrawals by use in Anne Arundel County from 1940 through 1980. 

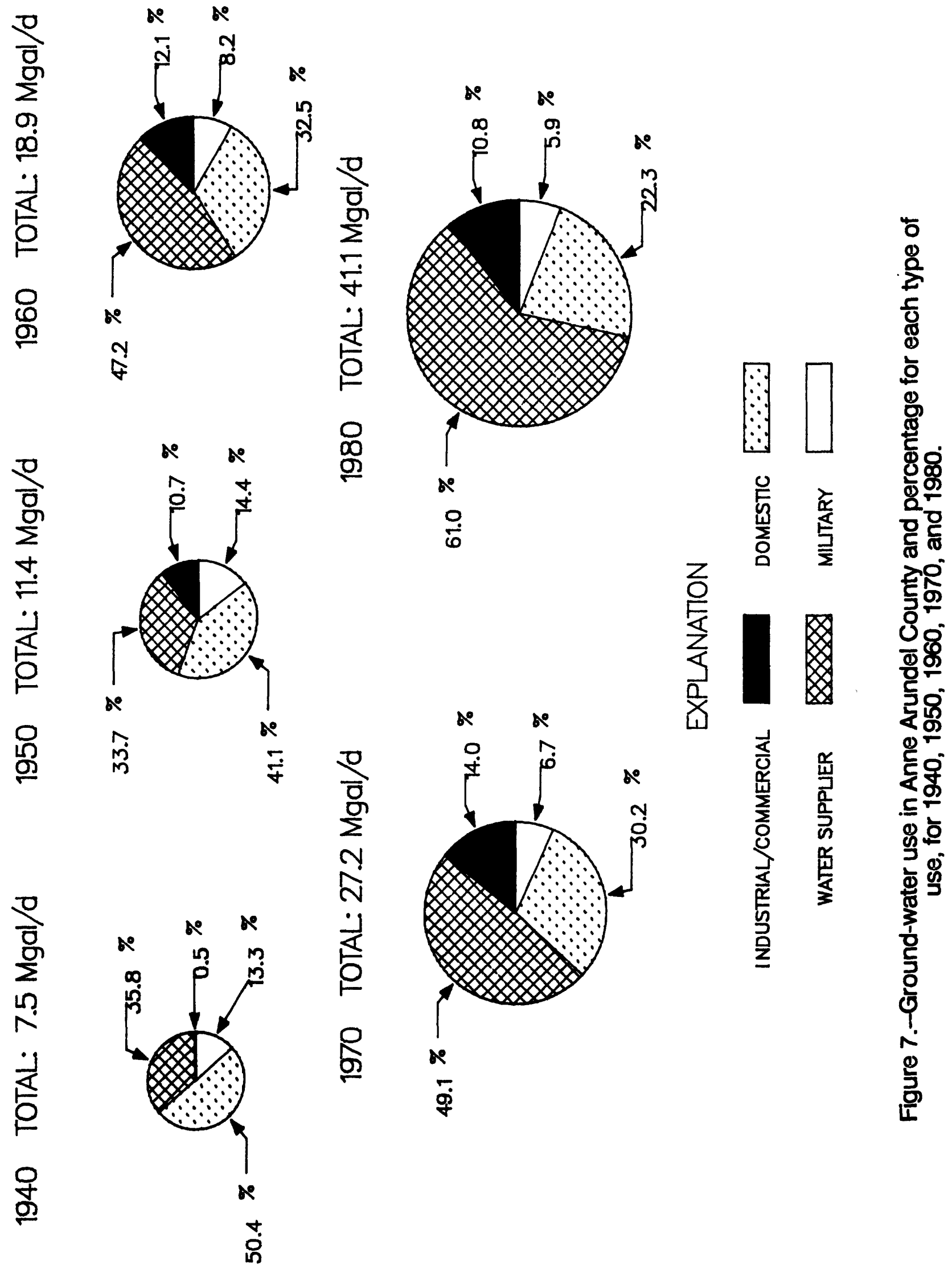


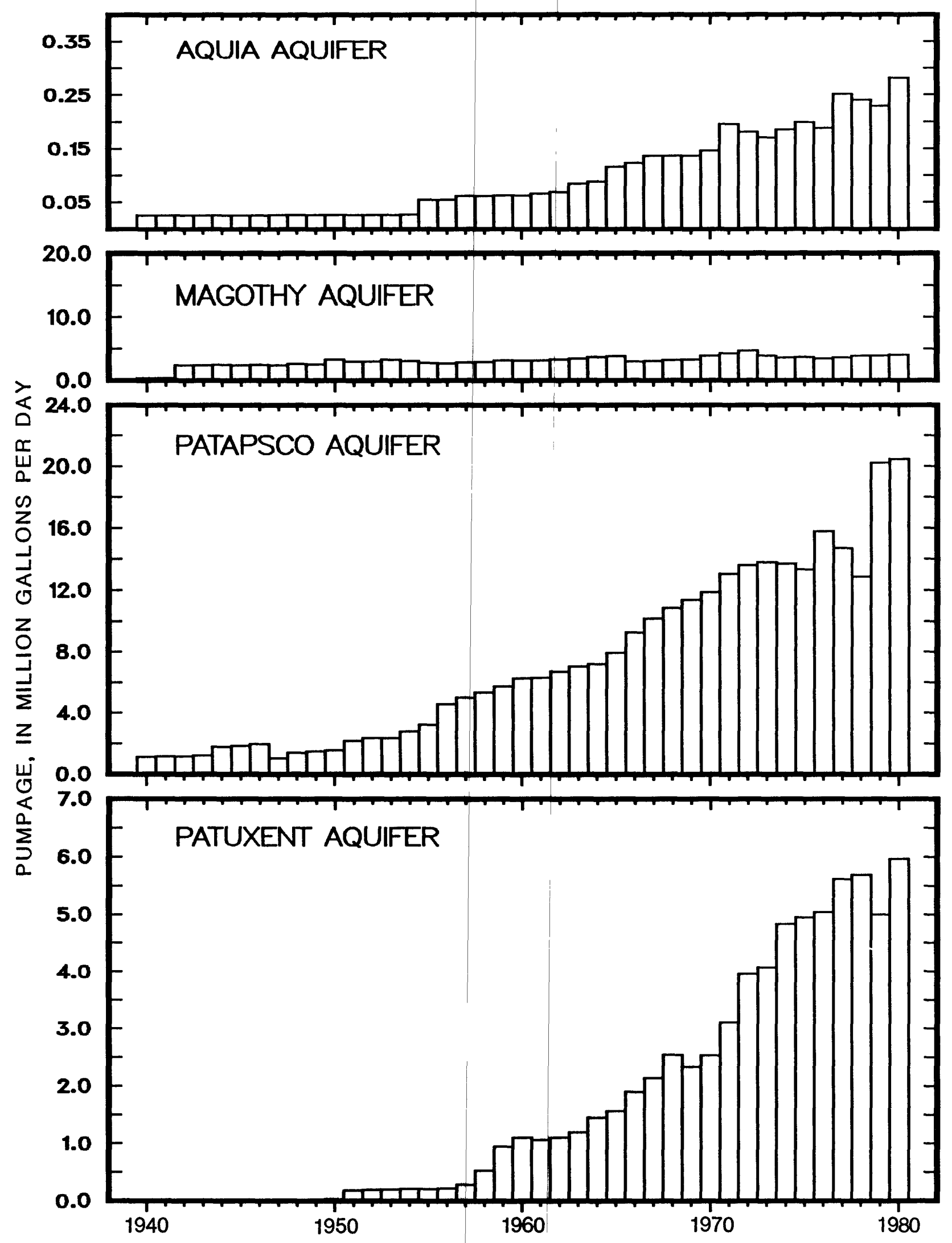

Figure 8.--Large ground-water withdrawals by aquifer in Anne Arundel County from 1940 through 1980. 

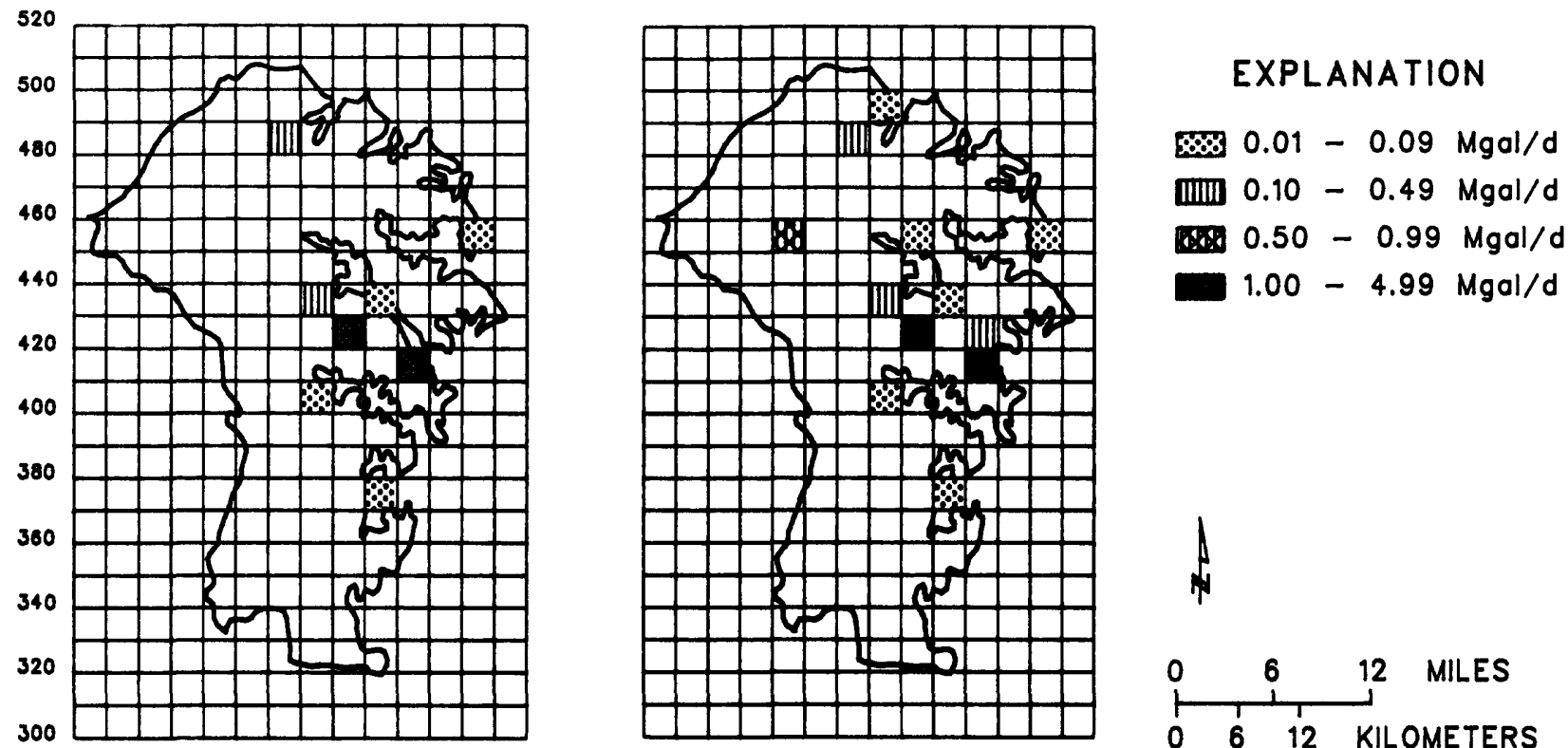

1960

1970

1980
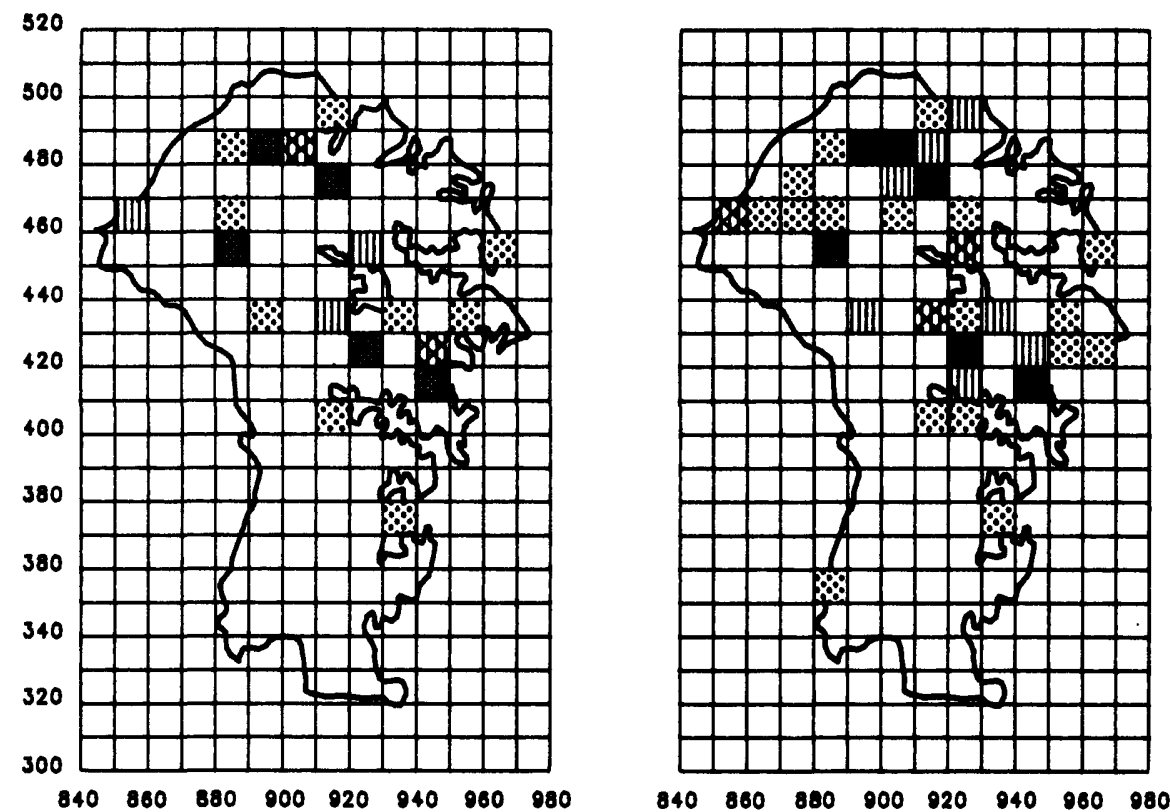

$\int_{1}$

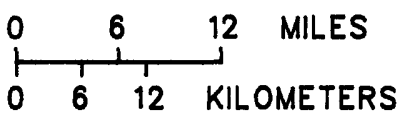

$\begin{array}{llll}0 & 6 & 12 & \text { KILOMETERS }\end{array}$

\footnotetext{
10,000-foot grid block in Maryland State Plane Coordinate

System. Grid cells are shaded to show the various pumpage in millions of gallons per day, withdrown within each block oreo. (Table 2 lists users contributing to the amount shown in a particular grid block).

480 Number times 1,000 is North coordinate.

$\frac{1}{940}$ Number times 1,000 is East coordinate.
}

Figure 9.--Locations of large ground-water withdrawals in Anne Arundel County for 1940, 1950, 1960, 1970, and 1980. 
Table 2.--Large ground-water users in Anne Arundel County in 1940, 1950, 1860, 1970, and 1880, summarized by the Maryland Grid Coordinate' System

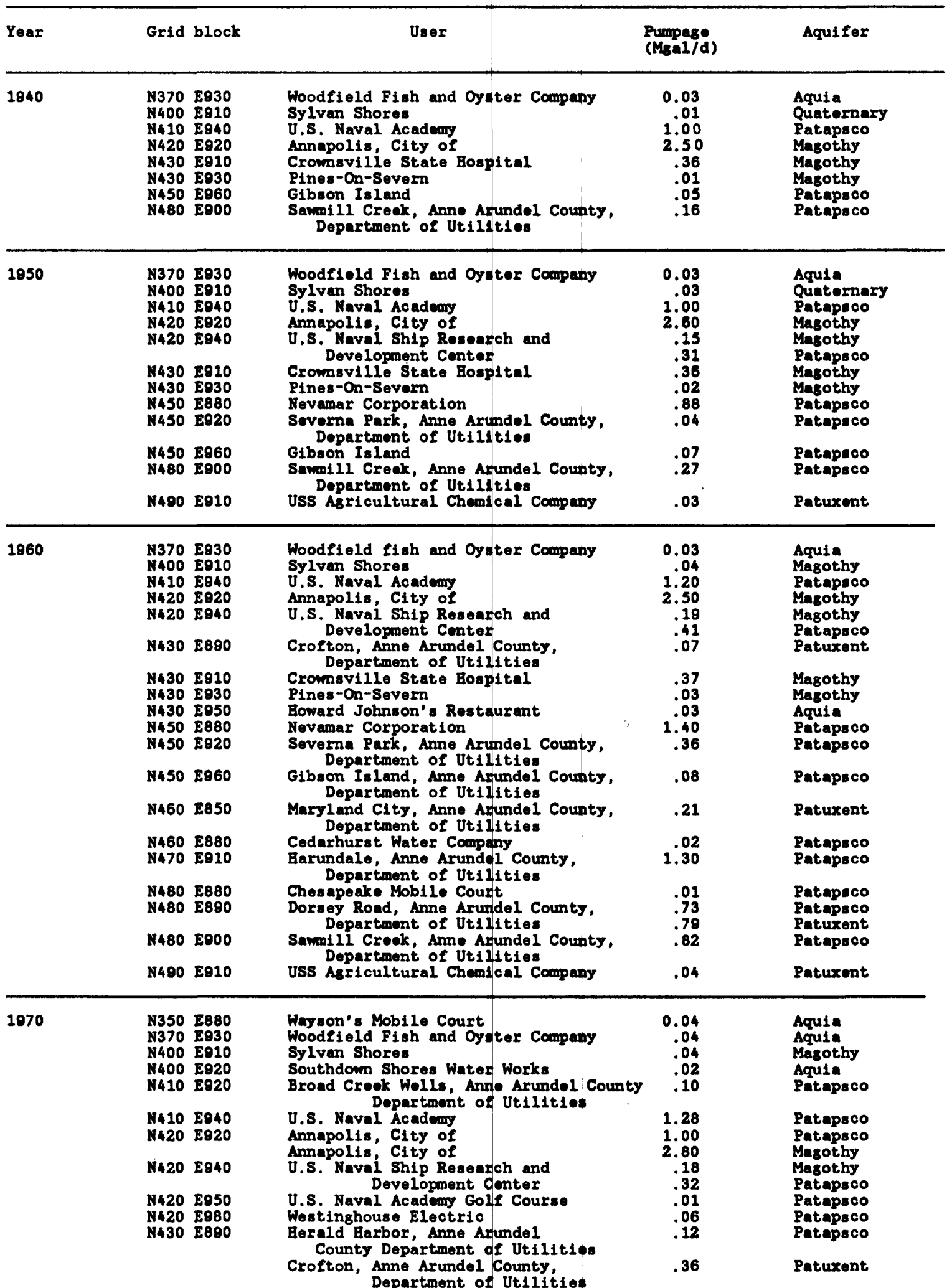


Table 2.--Large ground-water users in Anne Arundel County in 1940, 1950, 1960, 1970, and 1980, summarized by the Maryland Grid Coordinate System--Continued.

\begin{tabular}{|c|c|c|c|c|c|}
\hline Year & Grid & block & User & $\begin{array}{l}\text { Pumpage } \\
\text { (Mgal/d) }\end{array}$ & Aquifer \\
\hline$\left(1970-\right.$ Con' $\left.^{\prime} t\right)$ & $\begin{array}{l}\text { N430 } \\
N 430 \\
N 430 \\
N 430 \\
N 450 \\
N 450 \\
N 450 \\
N 460\end{array}$ & $\begin{array}{l}E 950 \\
E 880 \\
E 920 \\
E 960 \\
\text { E850 }\end{array}$ & $\begin{array}{l}\text { Crownsville State Hospital } \\
\text { Sherwood Forest Water Service } \\
\text { Pines-On-Severn, Anne Arundel County, } \\
\text { Department of Utilities } \\
\text { Epping Forest Water Works } \\
\text { Howard Johnson's Restaurant } \\
\text { Severn Mobile Home Court } \\
\text { Nevamar Corporation } \\
\text { Severna Park, Anne Arundel County, } \\
\text { Department of Utilities } \\
\text { Gibson Is land, Anne Arundel County, } \\
\text { Department of Utilities } \\
\text { Maryland City, Anne Arundel County, } \\
\text { Department of Utilities } \\
\text { Laurel Race Track } \\
\text { Holiday Inn Laurel } \\
\text { Colony Seven Motor Inn } \\
\text { Fort George Meade, U.S. Army } \\
\text { Cedarhurst Water Company } \\
\text { Transit Truck Stop } \\
\text { Pasadena Water Company } \\
\text { Holiday Mobile Estates } \\
\text { Crain Highway, Anne Arundel County, } \\
\text { Department of Utilities } \\
\text { Elvaton, Anne Arundel County, } \\
\text { Department of Utilities } \\
\text { Harundale, Anne Arundel County, } \\
\text { Department of Utilities } \\
\text { Parkway Industrial, Anne Arundel } \\
\text { County, Department of Utilities } \\
\text { Koppers Company } \\
\text { Koppers Company } \\
\text { Chesapeake Mobile Court } \\
\text { Dorsey Road, Anne Arundel County, } \\
\text { Department of Utilities } \\
\text { Two Guys Department Store } \\
\text { Sawmill Creek, Anne Arundel County, } \\
\text { Department of Utilities } \\
\text { Philiips Drive, Anne Arundel County, } \\
\text { Department of Utilities } \\
\text { Glendale, Anne Arundel County, } \\
\text { Department of Utilities } \\
\text { USS Agricultural Chemical Company } \\
\text { Chemetals }\end{array}$ & $\begin{array}{l}0.52 \\
.07 \\
.20 \\
.03 \\
.04 \\
.02 \\
2.40 \\
.76 \\
.08 \\
.51 \\
.06 \\
.01 \\
.03 \\
.04 \\
.02 \\
.02 \\
.04 \\
.04 \\
.03 \\
.14 \\
1.50 \\
.04 \\
.01 \\
.02 \\
.02 \\
1.50 \\
.98 \\
.20 \\
1.40 \\
.43 \\
.41 \\
.04 \\
.40\end{array}$ & $\begin{array}{l}\text { Magothy } \\
\text { Magothy } \\
\text { Magothy } \\
\text { Magothy } \\
\text { Aquia } \\
\text { Patapsco } \\
\text { Patapsco } \\
\text { Patapsco } \\
\text { Patapsco } \\
\text { Patuxent } \\
\text { Patuxent } \\
\text { Patuxent } \\
\text { Patuxent } \\
\text { Patuxent } \\
\text { Patapsco } \\
\text { Patapsco } \\
\text { Patapsco } \\
\text { Patuxent } \\
\text { Patapsco } \\
\text { Patapsco } \\
\text { Patapsco } \\
\text { Patuxent } \\
\text { Patapsco } \\
\text { Patuxent } \\
\text { Patapsco } \\
\text { Patapsco } \\
\text { Patuxent } \\
\text { Patapsco } \\
\text { Patapsco } \\
\text { Patapsco } \\
\text { Patapsco } \\
\text { Patuxent }\end{array}$ \\
\hline 1980 & $\begin{array}{l}\text { N340 } \\
\text { N350 } \\
\text { N350 } \\
\text { N350 } \\
\text { N370 } \\
\text { N370 } \\
\text { N370 } \\
\text { N390 } \\
\text { N390 } \\
\text { N390 } \\
\text { N400 }\end{array}$ & $\begin{array}{l}\text { E890 } \\
\text { E880 } \\
\text { E890 } \\
\text { E930 } \\
\\
\text { E890 } \\
\text { E900 } \\
\text { E930 } \\
\text { E890 } \\
\text { E900 } \\
\text { E920 } \\
\text { E910 }\end{array}$ & $\begin{array}{l}\text { Lyons Creek Mobile Homes } \\
\text { do. } \\
\text { Wayson's Mobile Court } \\
\text { Boones Mobile Estates } \\
\text { Broadwater Waste Plant, Anne Arundel } \\
\text { County, Department of Utilities } \\
\text { Maryland Manor Homes } \\
\text { Southern Senior High School } \\
\text { Woodfield Fish and Oyster Company } \\
\text { Sands Road Joint Venture } \\
\text { Homestead Gardens } \\
\text { Central Avenue School, Anne Arundel } \\
\quad \text { County, Department of Utilities } \\
\text { Sylvan Shores } \\
\text { Riva Development } \\
\text { Annapolis Landing Water Treatment Plant } \\
\text { Southdown Shores Water Works } \\
\text { Broad Creek wells, Anne Arundel County } \\
\quad \text { Department of Utilities } \\
\text { U.S. Naval Academy } \\
\text { Summer Hill Incorporated }\end{array}$ & $\begin{array}{r}0.04 \\
.04 \\
.05 \\
.02 \\
.01 \\
.07 \\
.03 \\
.04 \\
.05 \\
.01 \\
.03 \\
.04 \\
.03 \\
.03 \\
.03 \\
.38 \\
1.60 \\
.01\end{array}$ & $\begin{array}{l}\text { Magothy } \\
\text { Aquia } \\
\text { Aquia } \\
\text { Magothy } \\
\text { Aquia } \\
\text { Magothy } \\
\text { Magothy } \\
\text { Aqui a } \\
\text { Aquia } \\
\text { Aquia } \\
\text { Magothy } \\
\text { Magothy } \\
\text { Magothy } \\
\text { Magothy } \\
\text { Aqui a } \\
\text { Patapsco } \\
\text { Patapsco } \\
\text { Magothy }\end{array}$ \\
\hline
\end{tabular}


Table 2.--Large ground-water users in Anne Arundel County in 1940, 1950, 1960, 1970, and 1980, summarized by the Maryland Grid Coordinate System--Continued.

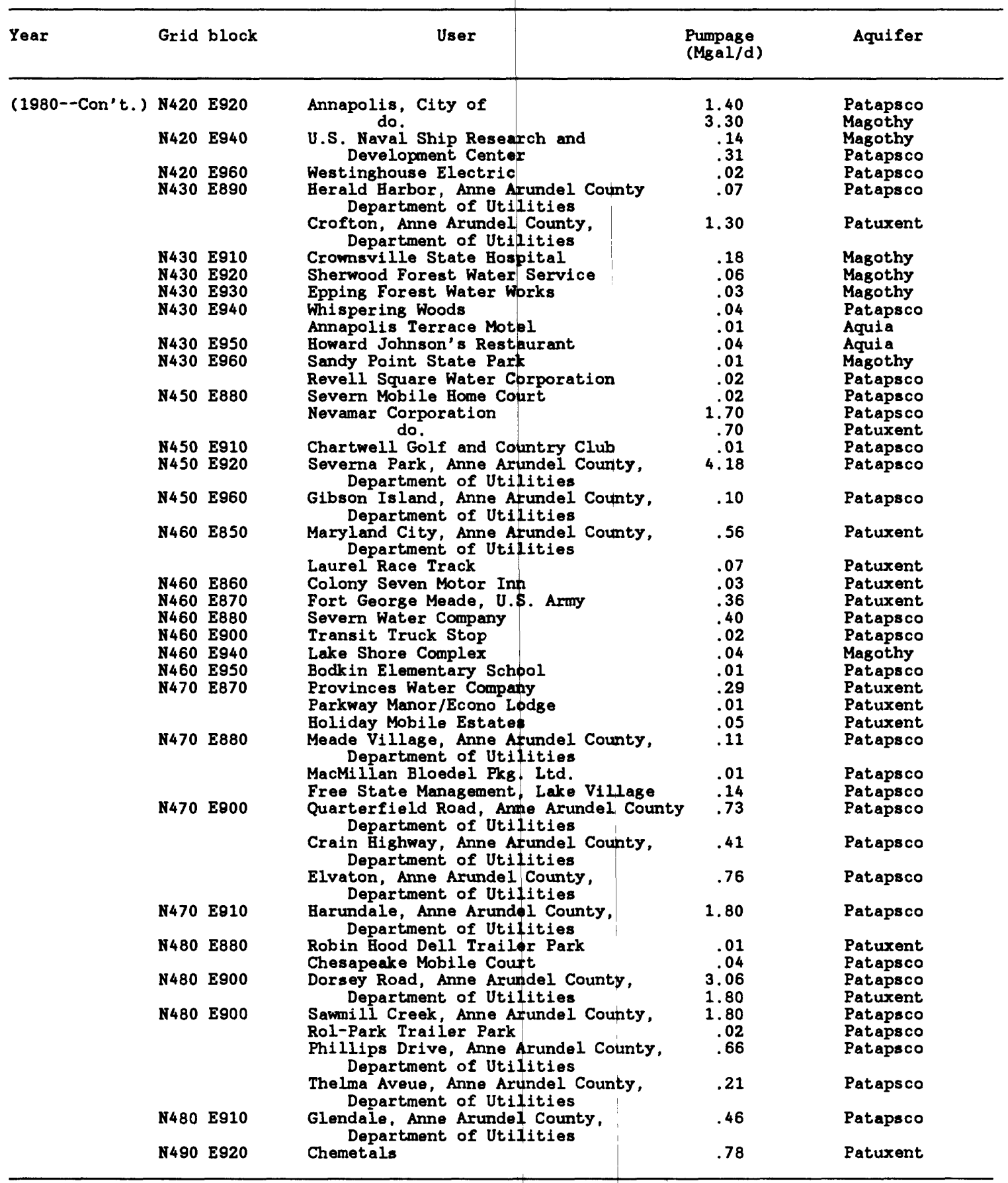



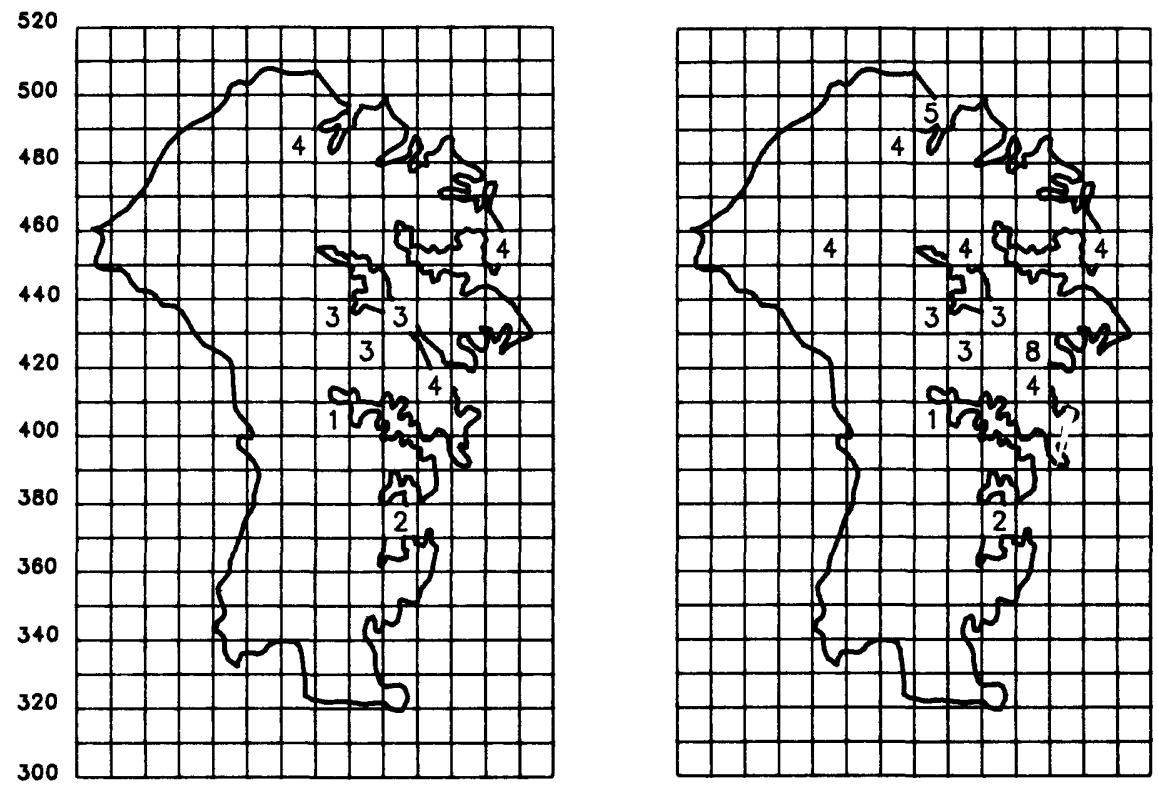

\section{EXPLANATION}

1 = Quaternary

$2=$ Aquia

3 = Magothy

4 = Patapsco

5 = Patuxent

6 = Aquia \& Magothy

7 = Aquia \& Patapsco

8 = Magothy \& Patapsco

9 = Patapsco \& Patuxent

$\mathbb{N}_{4}$

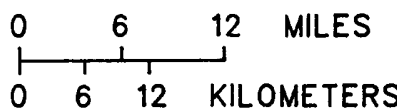

1960

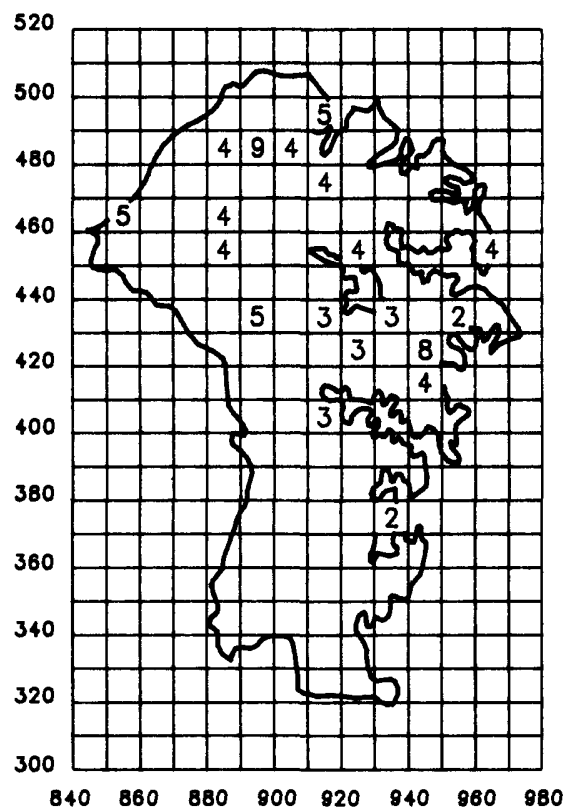

1970

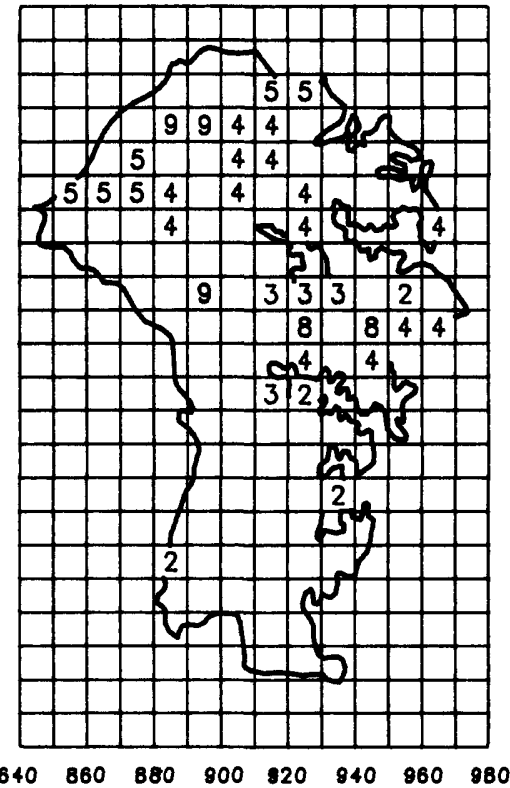

1980

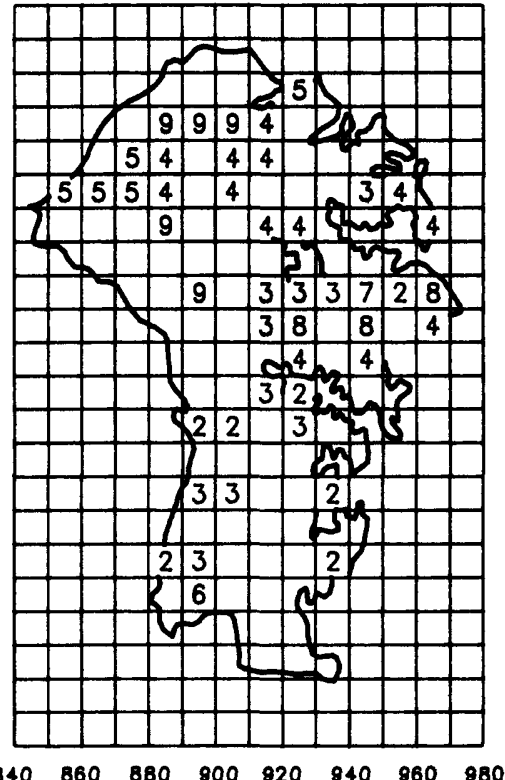

10,000-foot grid block in Maryland State Plane Coordinate

System. Numbers ore codes for the aquifer from which

water is withdrawn within a particular grid block.

480 Number times 1,000 is North coordinate.
$\frac{1}{940}$ Number times 1,000 is Eost coordinate.

Figure 10.--Locations of large ground-water withdrawals by aquifers in Anne Arundel County for 1940, 1950, 1960, 1970, and 1980. 


\section{BALTIMORE CITY}

Approximately one-half of Baltimore City lies in the Coastal Plain province. The first ground-water supplies in the Coastal Plain area of Baltimore City may have been developed as early as the 1600's (Bennett and Meyer, 1952). Most of the water was derived from shallow wells (from about 15 to $45 \mathrm{ft}$ deep). As the population grew and demands for water increased, the city turned to surface water to meet public supply needs. By 1855 , ground water was used very little, if at all, for public supply (Baltimore City Department of Public Works, 1970). By 1900, all large ground- water withdrawals in the Coastal Plain area of the city were by industries (see appendix).

Ground-water use by these industries from 1900 through 1980 is shown in figure 11 . In 1900, the amount of ground water withdrawn was approximately 7.4 $\mathrm{Mgal} / \mathrm{d}$. Pumpage increased the following years to a peak of nearly $25.1 \mathrm{Mgal} / \mathrm{d}$ in 1942 . However, in the years that followed, withdrawals declined until about 1960. Pumpage afterward remained relatively uniform, comprising approximately $3.3 \mathrm{Mgal} / \mathrm{d}$ in 1980 , which is about 4.1 Mgal/d less than it was in 1900 . See appendix for ground-water withdrawal data for each large user: User's name, appropriation permit number, source aquifer, location on the Maryland Grid Coordinate System, average daily pumpage, and year pumping began.

\section{Major Aquifers}

In the Coastal Plain area of Baltimore City, the Patapsco aquifer was used extensively during the early development of the Baltimore industrial area (prior to 1900). However, in many parts of the industrial dis- tricts of the city, saltwater intrusion from the Patapsco River contaminated the water and pumping from that aquifer was largely discontinued (Bennett and Meyer, 1952). Nevertheless, the Patapsco aquifer was used from the mid-1930's through the mid-1950's (fig. 12).

The Patuxent aquifer was the most important water-bearing formation used in the Coastal Plain area of Baltimore City. In 1900, approximately $7.4 \mathrm{Mgal} / \mathrm{d}$ were withdrawn. By 1942, pumpage from the aquifer peaked at nearly $24.0 \mathrm{Mgal} / \mathrm{d}$. Withdrawals then declined to about $3.2 \mathrm{Mgal} / \mathrm{d}$ in 1961 and remained relatively constant through 1980 .

\section{Locations of Large Ground-Water Withdrawals}

The locations of withdrawals by large users in the Coastal Plain portion of Baltimore City for 1930, 1940, $1950,1960,1970$, and 1980 are shown in figure 13. Table 3 presents water-use data for the large users located within particular grid blocks for the year indicated on the map. Areal distribution of large withdrawals remained about the same for all the years shown. However, fewer points of pumpage were noted in 1970 and 1980 than for the previous years presented.

The locations of withdrawal from individual aquifers supplying the large users in the Coastal Plain area of Baltimore City (described in table 3 and fig. 13) are shown in figure 14. Withdrawals from the Patapsco aquifer were limited to the southwestern part of the city. The Patuxent aquifer was the principal aquifer used for the years shown. It served the entire Coastal Plain portion of Baltimore City, although its use declined from 1960 to 1980. 


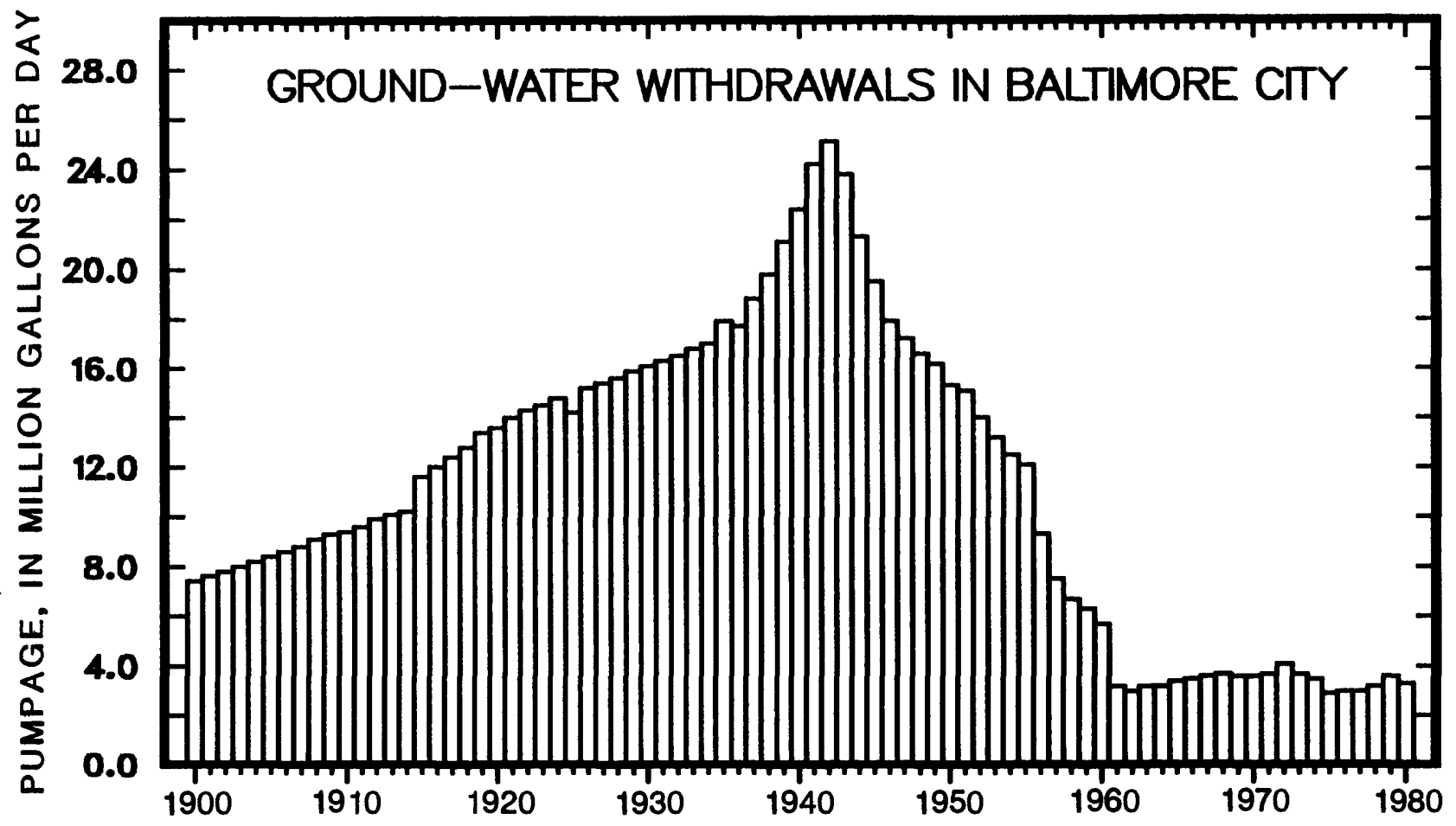

Figure 11.--Ground-water withdrawals in the Coastal Plain area of Baltimore City from 1900 through 1980.

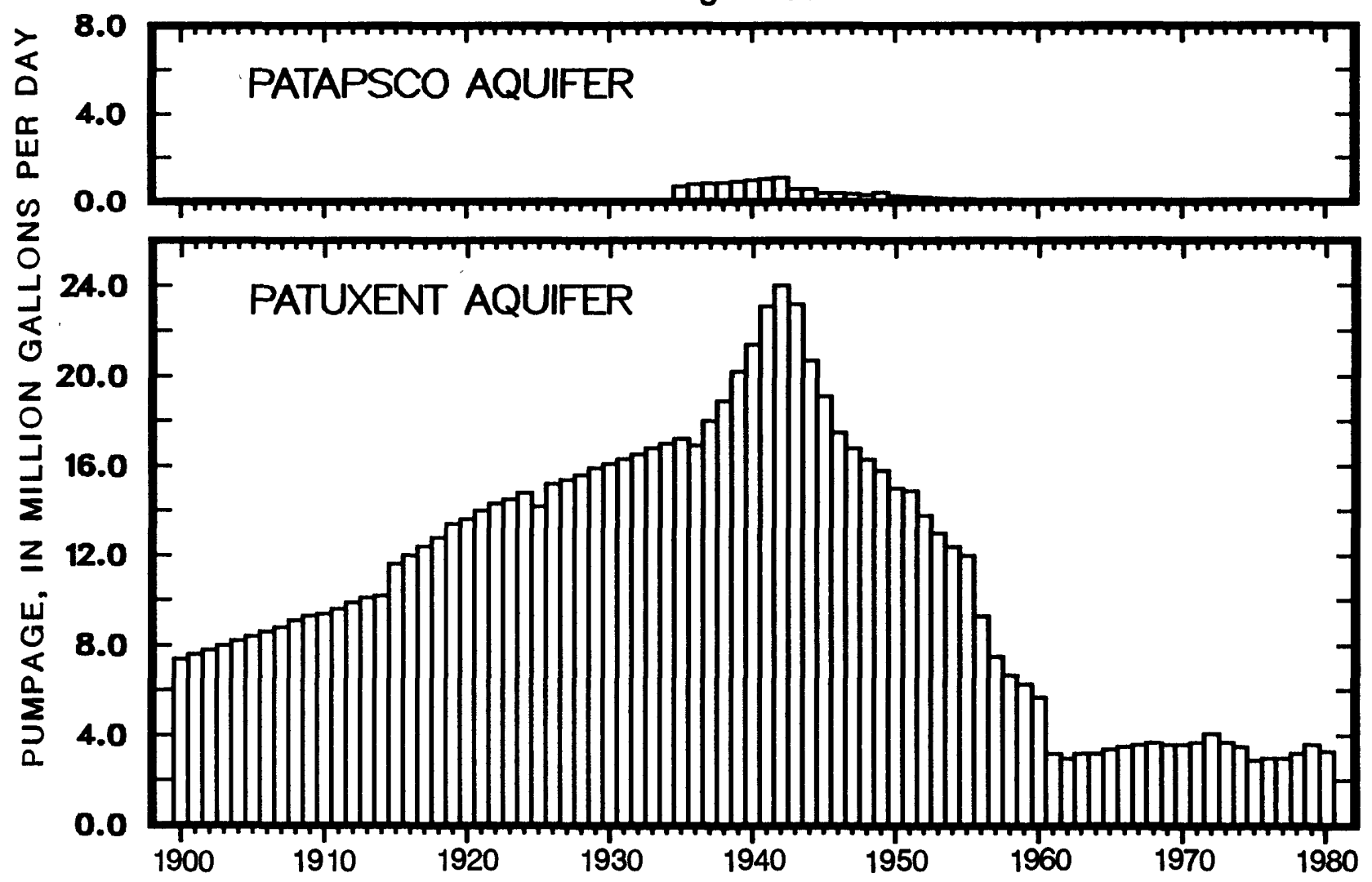

Figure 12.-- Large ground-water withdrawals by aquifers in the Coastal Plain area of Baltimore City from 1900 through 1980. 


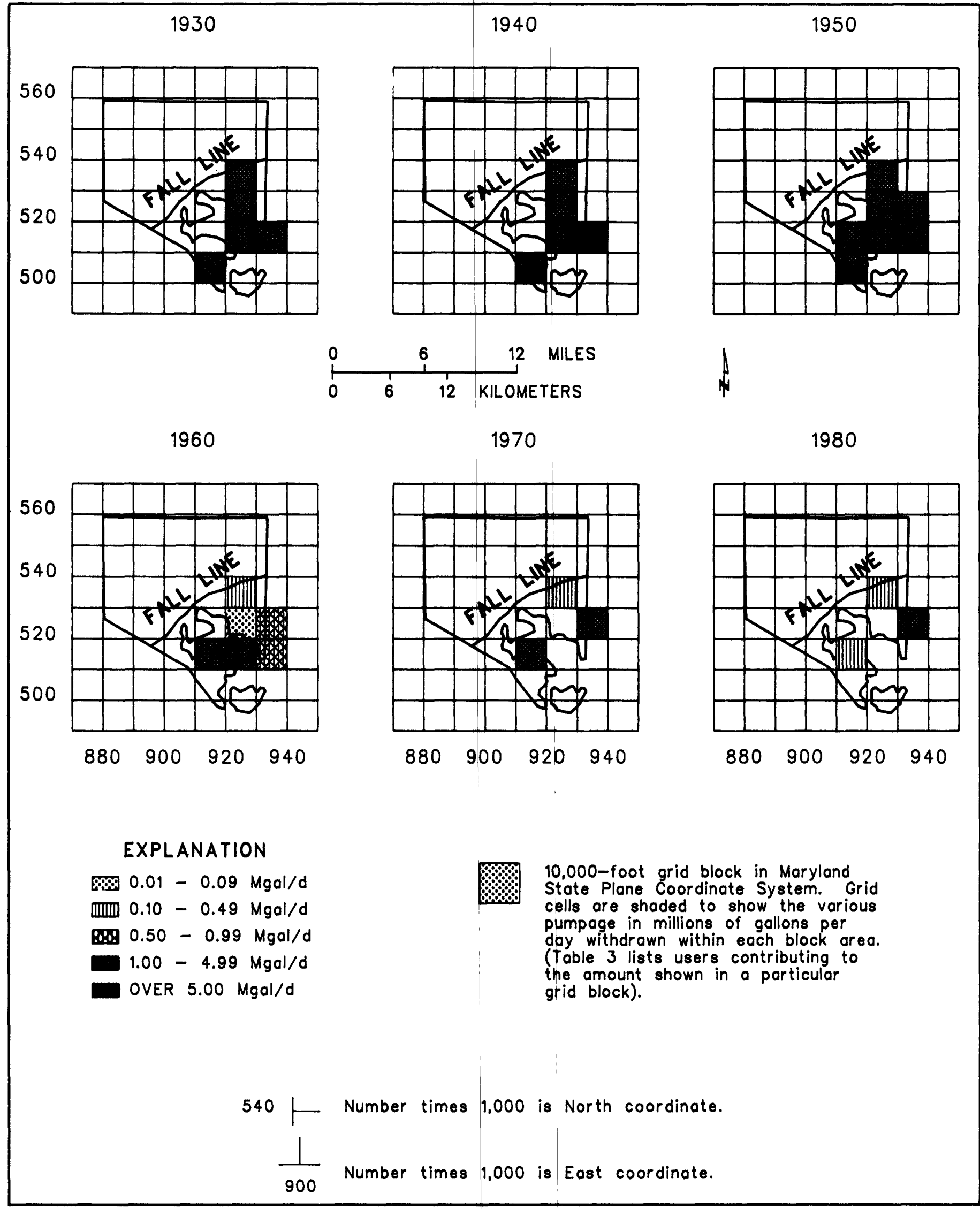

Figure 13.-- Locations of large ground-water withdrawals in the Coastal Plain area of Baltimore City for 1930, 1940, 1950, 1960, 1970, and 1980. 
Table 3.--Large ground-water users in the Coastal Plain area of Baltimore City in 1930, 1940, 1950, 1960,1970 , and 1980, summarized by the Maryland Grid Coordinate System

\begin{tabular}{|c|c|c|c|c|}
\hline Year & Grid block & User & $\begin{array}{l}\text { Pumpage } \\
\text { (Mgal/d) }\end{array}$ & Aquifer \\
\hline 1930 & $\begin{array}{ll}\text { N500 } & \mathbf{E 9 1 0} \\
\text { N510 } & \mathbf{E 9 2 0} \\
\text { N510 } & \mathbf{E 9 3 0} \\
\text { N520 } & \mathbf{E} 920 \\
& \\
\text { N530 } & \mathbf{E} 920\end{array}$ & $\begin{array}{l}\text { Curtis Bay District } \\
\text { Fairfield District } \\
\text { Dundalk District } \\
\text { Earbor District } \\
\text { do. } \\
\text { Canton District } \\
\text { Highlandtom District }\end{array}$ & $\begin{array}{l}2.70 \\
3.80 \\
3.80 \\
.27 \\
1.70 \\
2.20 \\
1.50\end{array}$ & $\begin{array}{l}\text { Patuxent } \\
\text { Patuxent } \\
\text { Patuxent } \\
\text { Quaternary } \\
\text { Patuxent } \\
\text { Patuxent } \\
\text { Patuxent }\end{array}$ \\
\hline 1940 & $\begin{array}{l}\text { N500 E910 } \\
\text { N510 E920. } \\
\text { N510 E930 } \\
\text { N520 E920 } \\
\text { N530 E920 }\end{array}$ & $\begin{array}{l}\text { Curtis Bay District } \\
\text { do. } \\
\text { Fairfield District } \\
\text { Dundalk District } \\
\text { Barbor District } \\
\text { do. } \\
\text { Canton District } \\
\text { Schluderberg-Kurdle, Incorporated } \\
\text { Paul Jones Company } \\
\text { Monarch Rubber } \\
\text { Crown Cork \& Seal }\end{array}$ & $\begin{array}{r}3.10 \\
.98 \\
4.90 \\
6.60 \\
.27 \\
2.30 \\
2.10 \\
.82 \\
.12 \\
.02 \\
1.10\end{array}$ & $\begin{array}{l}\text { Patuxent } \\
\text { Patapsco } \\
\text { Patuxent } \\
\text { Patuxent } \\
\text { Quaternary } \\
\text { Patuxent } \\
\text { Patuxent } \\
\text { Patuxent } \\
\text { Patuxent } \\
\text { Patuxent } \\
\text { Patuxent }\end{array}$ \\
\hline 1950 & $\begin{array}{ll}\text { N500 } & \mathbf{E} 910 \\
\text { N510 } & \mathbf{E} 910 \\
\text { N510 } & \mathbf{E} 920 \\
\text { N510 } & \mathbf{E 9 3 0} \\
\text { N520 } & \mathbf{E} 920 \\
& \\
\text { N520 } & \mathbf{E} 930 \\
\text { N530 } & \mathbf{E} 920\end{array}$ & $\begin{array}{l}\text { Curtis Bay District } \\
\text { do. } \\
\text { F.M.C. Corporation } \\
\text { Fairfield District } \\
\text { Dundalk District } \\
\text { Barbor District } \\
\text { do. } \\
\text { Canton District } \\
\text { Federal Yeast Corporation } \\
\text { Schluderberg-Kurdle, Incorporated } \\
\text { Paul Jones Company } \\
\text { Monarch Rubber Company } \\
\text { Crown Cork \& Seal }\end{array}$ & $\begin{array}{r}0.83 \\
.26 \\
1.60 \\
3.30 \\
3.70 \\
.08 \\
1.70 \\
.42 \\
1.00 \\
.79 \\
.11 \\
.06 \\
1.50\end{array}$ & $\begin{array}{l}\text { Patuxent } \\
\text { Patapsco } \\
\text { Patuxent } \\
\text { Patuxent } \\
\text { Patuxent } \\
\text { Quaternary } \\
\text { Patuxent } \\
\text { Patuxent } \\
\text { Patuxent } \\
\text { Patuxent } \\
\text { Patuxent } \\
\text { Patuxent } \\
\text { Patuxent }\end{array}$ \\
\hline 1960 & $\begin{array}{ll}\text { N510 } & \mathrm{E} 910 \\
\text { N510 } & \mathrm{E} 920 \\
\text { N510 } & \mathrm{E} 930 \\
\text { N520 } & \mathrm{E} 920 \\
\text { N520 } & \mathrm{E} 930 \\
\text { N530 } & \mathrm{E} 920\end{array}$ & $\begin{array}{l}\text { F.M.C. Corporation } \\
\text { Fairfield District } \\
\text { Dundalk District } \\
\text { Canton District } \\
\text { Federal Yeast Corporation } \\
\text { Schluderbers-Kurdle, Incorporated }\end{array}$ & $\begin{array}{r}1.90 \\
1.80 \\
.90 \\
.08 \\
.65 \\
.41\end{array}$ & $\begin{array}{l}\text { Patuxent } \\
\text { Patuxent } \\
\text { Patuxent } \\
\text { Patuxent } \\
\text { Patuxent } \\
\text { Patuxent }\end{array}$ \\
\hline 1970 & $\begin{array}{ll}\text { N510 } & \mathbf{E} 910 \\
\text { N520 } & \mathbf{E 9 3 0} \\
\text { N530 } & \mathbf{E} 920\end{array}$ & $\begin{array}{l}\text { F.M.C. Corporation } \\
\text { Federal Yeast Corporation } \\
\text { Schluderberg-Kurdle, Incorporated } \\
\text { Bood Vinegar Company }\end{array}$ & $\begin{array}{r}2.00 \\
1.40 \\
.16 \\
.07\end{array}$ & $\begin{array}{l}\text { Patuxent } \\
\text { Patuxent } \\
\text { Patuxent } \\
\text { Patuxent }\end{array}$ \\
\hline 1980 & $\begin{array}{ll}\text { N510 } & \mathbf{E} 910 \\
\text { N520 } & \mathbf{E} 930 \\
\text { N530 } & \mathbf{E} 920\end{array}$ & $\begin{array}{l}\text { F.M.C. Corporation } \\
\text { Federal Yeast Corporation } \\
\text { Schluderberg-Kurdle, Incorporated } \\
\text { Bood Vinegar Company }\end{array}$ & $\begin{array}{r}0.42 \\
2.60 \\
.23 \\
.08\end{array}$ & $\begin{array}{l}\text { Patuxent } \\
\text { Patuxent } \\
\text { Patuxent } \\
\text { Patuxent }\end{array}$ \\
\hline
\end{tabular}




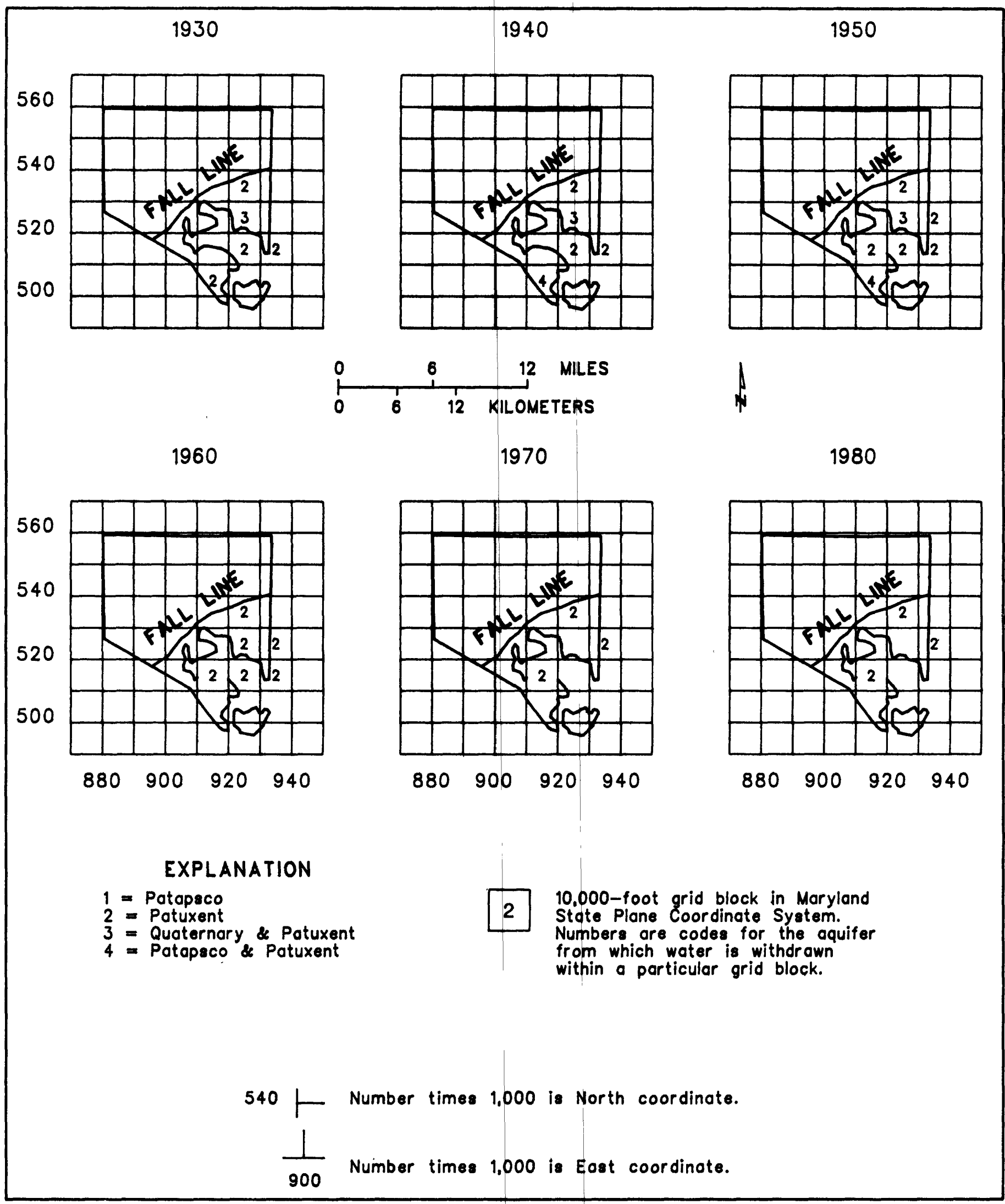

Figure 14.--Locations of large ground-water withdrawals by aquifer in the Coastal Plain area of Baltimore City for 1930, 1940, 1950, 1960, 1970, and 1980. 


\section{BALTIMORE COUNTY}

About one-fifth of Baltimore County lies within the Maryland Coastal Plain. Since the early development of this area, ground water has been a source of water supply for many users (Bennett and Meyer, 1952). Much of the early withdrawals were from shallow wells (from about 15 to $80 \mathrm{ft}$ deep) tapping the surficial aquifer. However, as a result of years of heavy pumping, some portions of this aquifer became contaminated with saline water from adjacent estuaries (Bennett and Meyer, 1952). Over time, increasing public-water supply demands were met by extending Baltimore City waterlines farther into the county (Baltimore County Department of Public Works, 1970); however, many large ground-water users, primarily industries, continued to rely on deeper aquifers, including the Patapsco and Patuxent, to meet their needs.

Ground-water use in the Coastal Plain part of the county from 1930 through 1980 is shown in figure 15. In 1930 , the amount of ground water withdrawn was approximately $6.3 \mathrm{Mgal} / \mathrm{d}$. Withdrawals increased to a peak of nearly $23.0 \mathrm{Mgal} / \mathrm{d}$ in 1942 , then declined during the next 2 years to approximately $12.4 \mathrm{Mgal} / \mathrm{d}$ in 1944 . Although pumpage increased again several times (17.2 in 1958 and 14.2 in 1969), the general trend was downward, and by 1980 withdrawals were about 6.2 $\mathrm{Mgal} / \mathrm{d}$. See appendix for ground-water withdrawal data for each large user: User's name, appropriation permit number, source aquifer, location on the Maryland Grid Coordinate System, the average daily pumpage, and year pumping began.

The percentages of the total amount of ground water withdrawn for domestic and industrial uses for $1930,1940,1950,1960,1970$, and 1980 are shown in figure 16. Nearly all ground water withdrawn was for industrial use.

\section{Major Aquifers}

The surficial (Quaternary), Patapsco, and Patuxent were the most heavily used aquifers in the Coastal Plain area of Baltimore County from 1930 through 1980 (fig. 17). Use of the surficial aquifer began in $1942(0.5$ $\mathrm{Mgal} / \mathrm{d}$ ) and withdrawals remained relatively the same through 1980.
Use of the Patapsco aquifer was extensive, although, in some areas, heavy pumping caused saltwater intrusion from the Patapsco River which contaminated the aquifer (Bennett and Meyer, 1952). In 1930, pumpage was about $2.8 \mathrm{Mgal} / \mathrm{d}$ and increased to nearly $10.0 \mathrm{Mgal} / \mathrm{d}$ in 1942 . Withdrawals then declined markedly (to approximately $2.8 \mathrm{Mgal} / \mathrm{d}$ in 1943). By 1946, pumpage from the Patapsco increased again to nearly $6.0 \mathrm{Mgal} / \mathrm{d}$. Over the next 10 years, pumpage remained at approximately this amount; then in 1957, it increased to more than $9.0 \mathrm{Mgal} / \mathrm{d}$. Withdrawals then began a general downward trend; by 1980 , pumpage was only about $0.02 \mathrm{Mgal} / \mathrm{d}$.

The Patuxent was the most heavily used aquifer supplying water to large industries in the Coastal Plain portion of the county. In 1930, approximately 3.5 $\mathrm{Mgal} / \mathrm{d}$ were withdrawn. By 1942, withdrawals had increased to more than $12.0 \mathrm{Mgal} / \mathrm{d}$. Although withdrawals declined through the early 1960's, they did reach nearly $10.0 \mathrm{Mgal} / \mathrm{d}$ in 1970 before declining again to about $5.4 \mathrm{Mgal} / \mathrm{d}$ in 1980 .

\section{Locations of Large Ground-Water Withdrawals}

The locations of withdrawals by large users in the Coastal Plain area of Baltimore County for 1930, 1940, $1950,1960,1970$, and 1980 are shown in figure 18 . Table 4 presents water-use data for the large users located within particular grid blocks for the year indicated on the map.

As shown in figure 18, the areas of heaviest pumpage in 1930 were confined to two locations, with the greatest amount being withdrawn at the steel plant at Sparrows Point. There was little change in the distribution pattern for the following years shown, except for an increase in the number of pumpage sites, especially during 1970 and 1980 .

The locations of withdrawals from individual aquifers supplying the large users in Baltimore County (described in table 4 and fig. 18) are shown in figure 19. The use of the Patapsco aquifer was limited to the Sparrows Point area. The Patuxent aquifer was the predominant source of ground water for all of the years shown. Its use was greatest in the heavily industrial section of the county--the area bordering the eastern side of Baltimore City, particularly at Sparrows Point. 


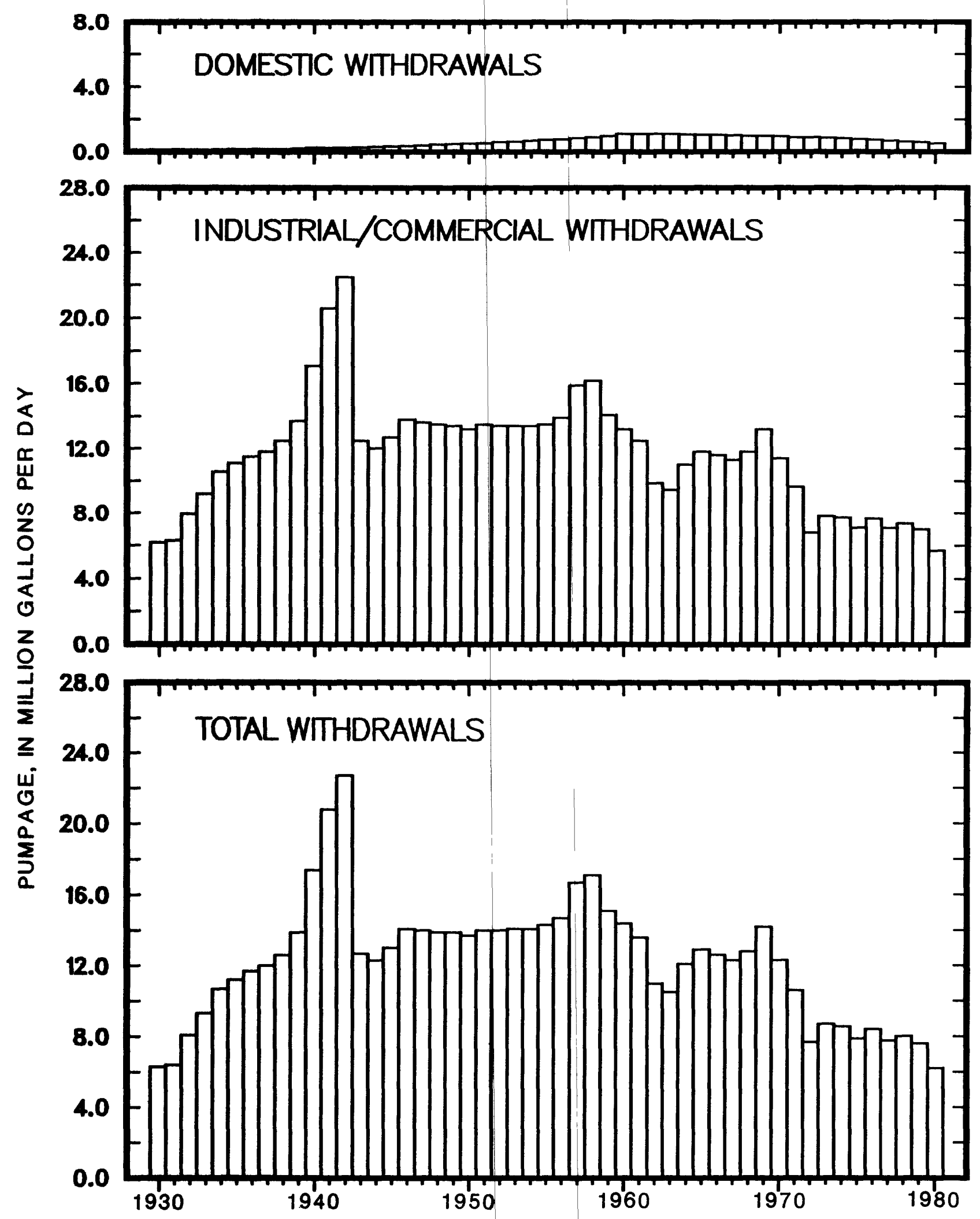

Figure 15.-- Ground-water withdrawals by use in the Coastal Plain area of Baltimore County from 1930 through 1980. 


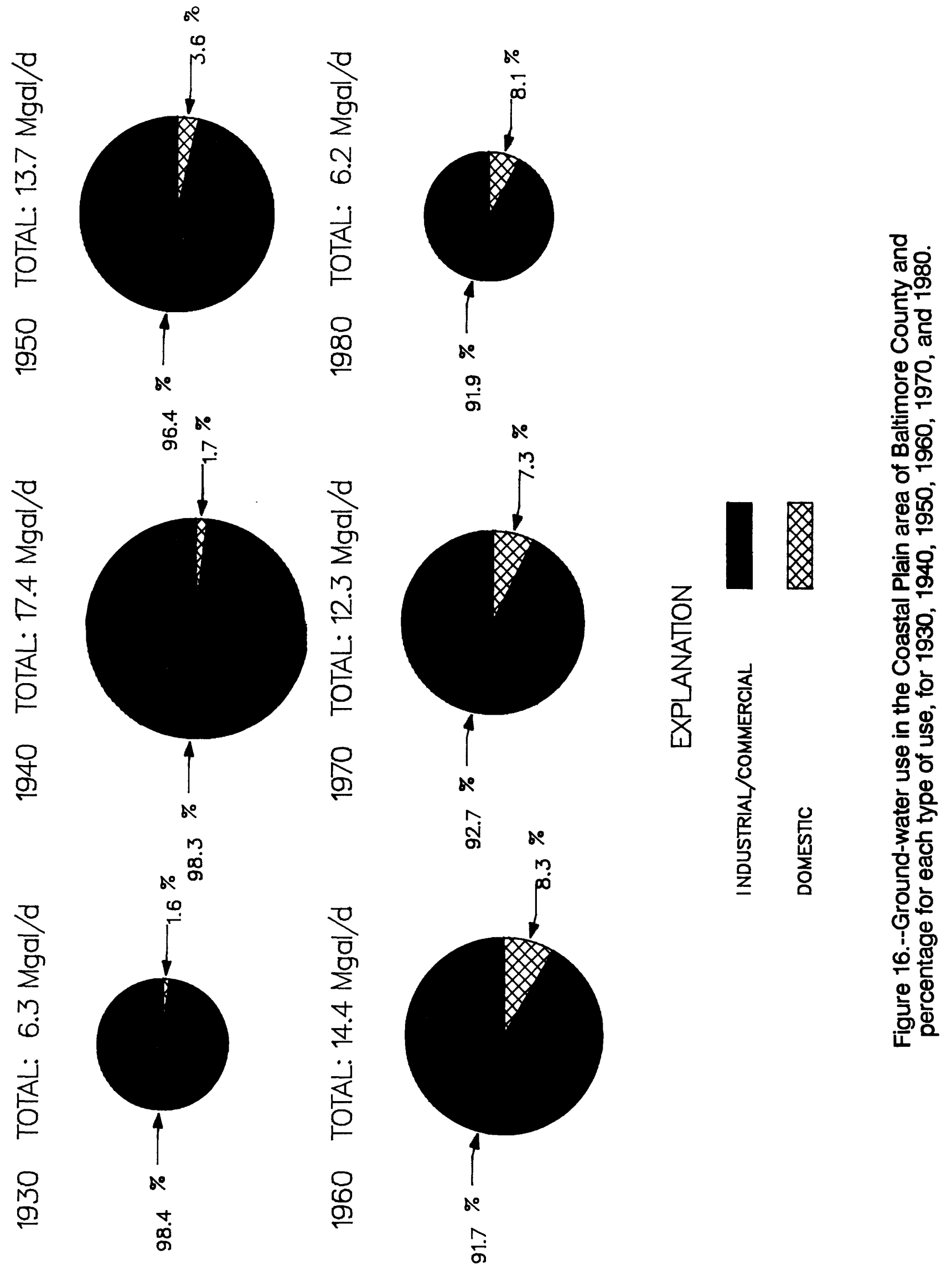




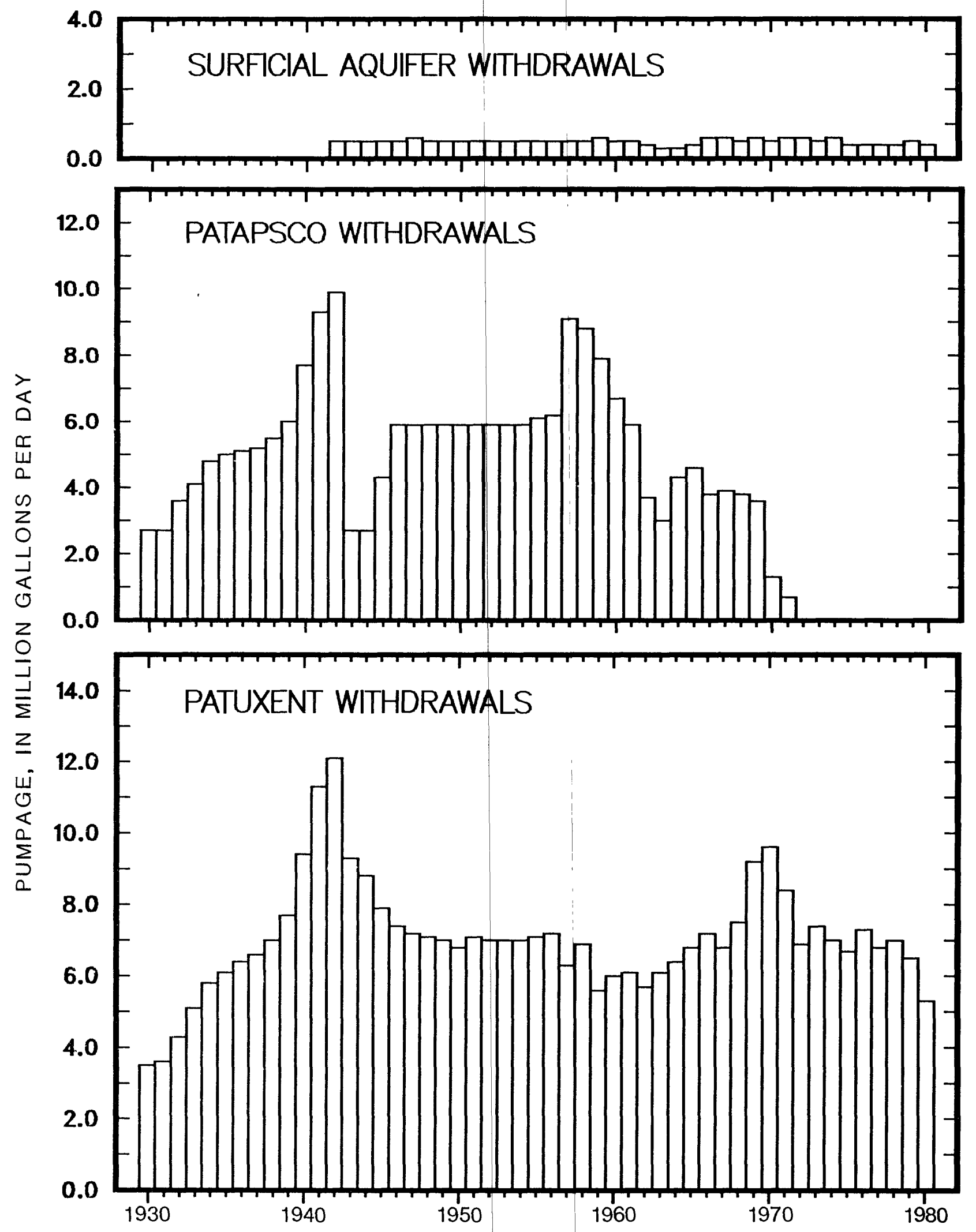

Figure 17.-- Large ground-water withdrawals by aquifers in the Coastal Plain area of Baltimore County from 1930 through 1980. 


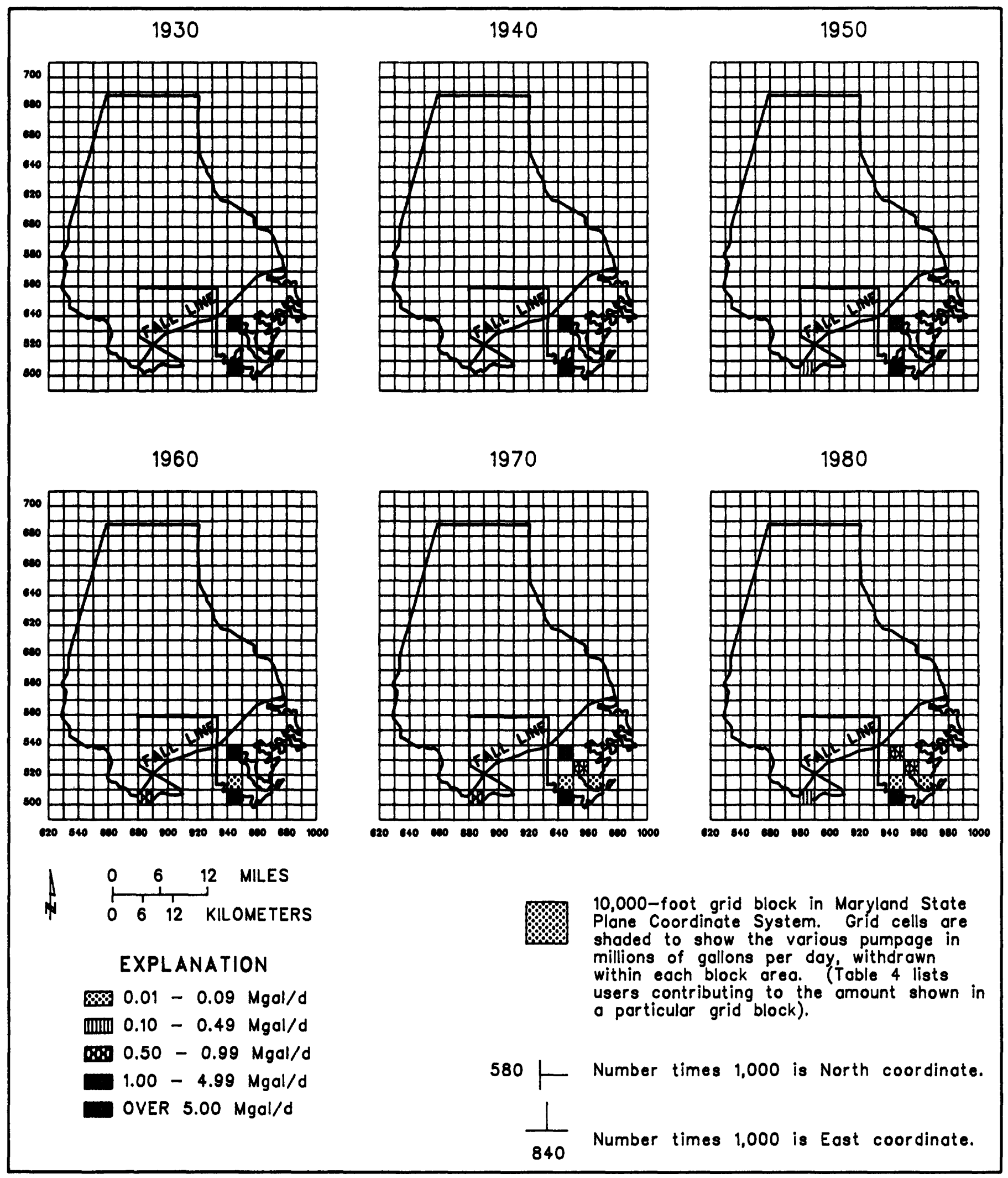

Figure 18.--Locations of large ground-water withdrawals in the Coastal Plain area of Baltimore County for 1930, 1940, 1950, 1960, 1970, and 1980. 
Table 4.--Large ground-water users in the Coastal Plain area of Baltimore County in 1930, 1940, 1950, 1960, 1970, and 1980, summarized by the Maryland Grid Coordinate System

\begin{tabular}{|c|c|c|c|c|}
\hline Year & Grid block & User & $\begin{array}{l}\text { umpage } \\
\mathrm{Mgal} / \mathrm{d} \text { ) }\end{array}$ & Aquifer \\
\hline 1930 & $\begin{array}{l}\text { N500 E940 } \\
\text { N530 E940 }\end{array}$ & $\begin{array}{l}\text { Bethlehem Steel Corp. (Sparrows Point) } \\
\text { do. } \\
\text { Eastern Stainless Steel Corporation }\end{array}$ & $\begin{array}{r}2.70 \\
2.70 \\
.82\end{array}$ & $\begin{array}{l}\text { Patuxent } \\
\text { Patapsco } \\
\text { Patuxent }\end{array}$ \\
\hline 1940 & $\begin{array}{l}\mathbf{N 5 0 0} \mathbf{E 9 4 0} \\
\mathbf{N 5 3 0} \mathbf{E 9 4 0}\end{array}$ & $\begin{array}{l}\text { Bethlehem Steel Corp. (Sparrow Point) } \\
\text { do. } \\
\text { Eastern Stailess Steel Corporation }\end{array}$ & $\begin{array}{l}7.70 \\
7.70 \\
1.80\end{array}$ & $\begin{array}{l}\text { Patuxent } \\
\text { Patapsco } \\
\text { Patuxent }\end{array}$ \\
\hline 1850 & $\begin{array}{l}\text { N500 } \mathbf{E 8 8 0} \\
\mathbf{N 5 0 0} \mathbf{E 9 4 0} \\
\text { N530 } \mathbf{E 9 4 0}\end{array}$ & $\begin{array}{l}\text { Jos. E. Seagram \& Son } \\
\text { (Calvert Distillery) } \\
\text { Bethlehem Steel Corp. (Sparrow Point) } \\
\text { do. } \\
\text { Eastern Stainless Stepl Corporation }\end{array}$ & $\begin{array}{l}0.47 \\
5.50 \\
5.80 \\
1.40\end{array}$ & $\begin{array}{l}\text { Quaternary } \\
\text { Patuxent } \\
\text { Patapsco } \\
\text { Patuxent }\end{array}$ \\
\hline 1960 & $\begin{array}{l}\text { N500 } \mathbf{E 8 8 0} \\
\text { N500 } \mathbf{E 9 4 0} \\
\text { N510 } \\
\text { R530 } \\
\mathbf{E} 940\end{array}$ & $\begin{array}{l}\text { Jos. E. Seagram \& Sons } \\
\text { (Calvert Dist1llery) } \\
\text { Bethlehem Steel Corp. (Sparrow Point) } \\
\text { do. } \\
\text { Joseph S. Merritt, Incorporated } \\
\text { Eastern Stainless Steol Corporation }\end{array}$ & $\begin{array}{r}0.54 \\
4.90 \\
6.70 \\
.01 \\
1.10\end{array}$ & $\begin{array}{l}\text { Quaternary } \\
\text { Patuxent } \\
\text { Patapsco } \\
\text { Patapsco } \\
\text { Patuxent }\end{array}$ \\
\hline 1870 & $\begin{array}{ll}\text { N500 } & \mathbf{E} 880 \\
\text { N500 } & \mathbf{E} 940 \\
\text { N510 } & \mathbf{E} 940 \\
\text { N510 } & \mathbf{E} 960 \\
\text { N520 } & \mathbf{E} 950 \\
\text { N530 } & \mathbf{E} 940\end{array}$ & $\begin{array}{l}\text { Jos. E. Seagram a Sons } \\
\text { (Calvert Distillery) } \\
\text { Bethlehem Steel Corp. (Sparrow Point) } \\
\text { do. } \\
\text { Joseph S. Merritt, Incorporated } \\
\text { Rocky Point Gole Courge } \\
\text { American Yeast Corporation } \\
\text { Eastern Stainless stebl Corporation }\end{array}$ & $\begin{array}{r}0.53 \\
7.80 \\
1.20 \\
.02 \\
.02 \\
.70 \\
1.10\end{array}$ & $\begin{array}{l}\text { Quaternary } \\
\text { Patuxent } \\
\text { Patapsco } \\
\text { Patapsco } \\
\text { Patuxent } \\
\text { Patuxent } \\
\text { Patuxent }\end{array}$ \\
\hline 1980 & $\begin{array}{ll}\text { N500 } & \mathbf{E} 880 \\
\text { N500 } & \mathbf{E} 940 \\
\text { N510 } & \mathbf{E} 940 \\
\text { N510 } & \mathbf{E} 960 \\
\text { N520 } & \mathbf{E} 950 \\
\text { M530 } & \mathbf{E} 940\end{array}$ & $\begin{array}{l}\text { Jos. E. Seagram \& Sons } \\
\text { (Calvert Distillery) } \\
\text { Bethlehem Steel Corp. (Sparrows Point) } \\
\text { Joseph S. Merritt, Incorporated } \\
\text { Rocky Point Golf Course } \\
\text { American Yeast Corporation } \\
\text { Eastern Stainless Steol Corporation }\end{array}$ & $\begin{array}{l}0.42 \\
3.60 \\
.02 \\
.04 \\
.70 \\
.86\end{array}$ & $\begin{array}{l}\text { Quaternary } \\
\text { Patuxent } \\
\text { Patapsco } \\
\text { Patuxent } \\
\text { Patuxent } \\
\text { Patuxent }\end{array}$ \\
\hline
\end{tabular}




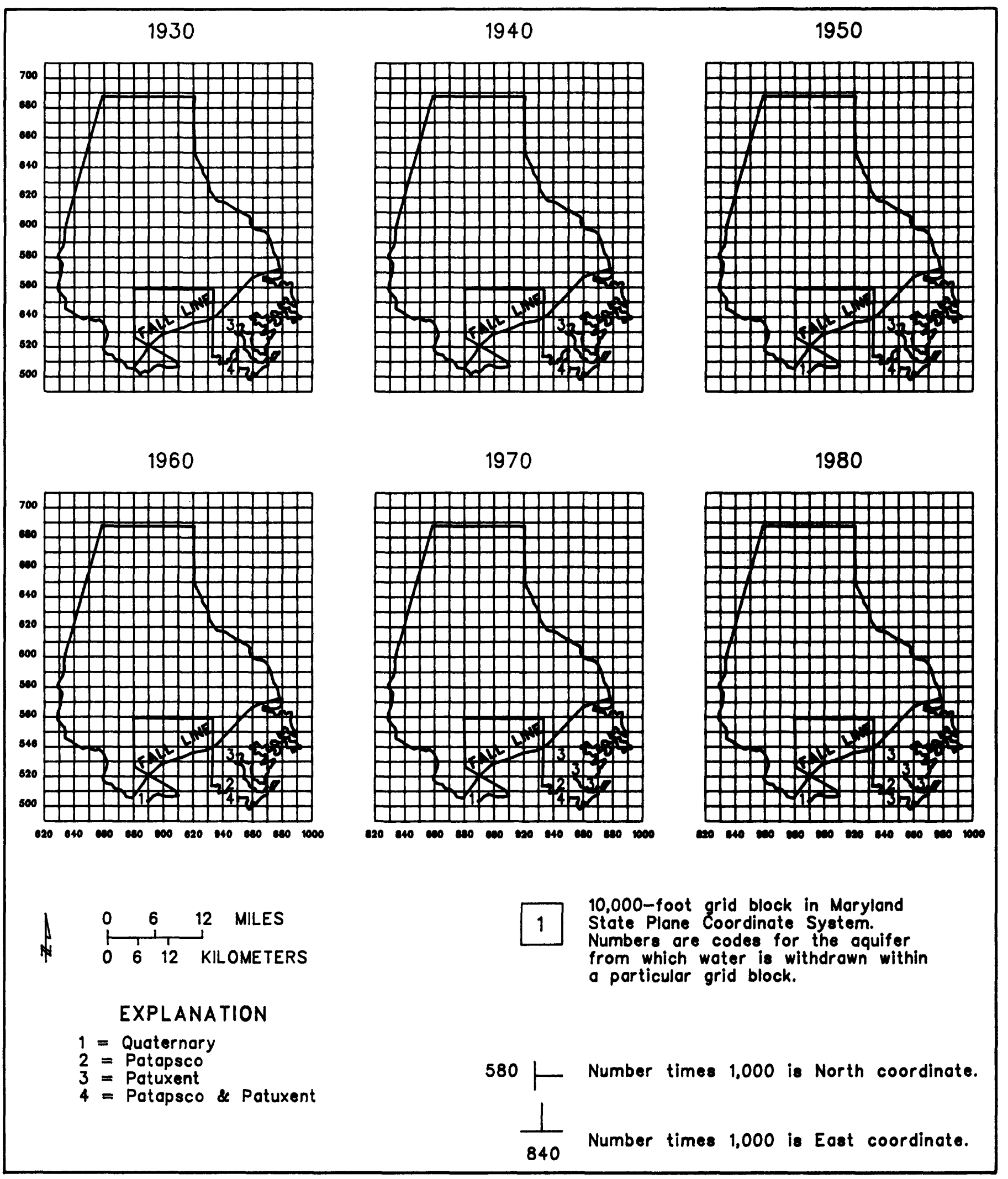

Figure 19.--Locations of large ground-water withdrawals by aquifers in the Coastal Plain area of Baltimore County for 1930, 1940, 1950, 1960, 1970, and 1980. 


\section{CALVERT COUNTY}

Ground-water use in Calvert County from 1940 through 1980 is shown in figure 20. In 1940, the amount of ground water withdrawn was approximately 0.8 $\mathrm{Mgal} / \mathrm{d}$ compared to withdrawals of about $2.8 \mathrm{Mgal} / \mathrm{d}$ in 1980. This represents an increase of 250 percent for the four decades. The figure also indicates that for most of the period, the largest withdrawals of ground water were for domestic use. Military use was greatest during the period 1941 (0.8 Mgal/d) through 1949 (0.6 Mgal/d). By 1980, however, military withdrawals had declined to about $0.1 \mathrm{Mgal} / \mathrm{d}$. Large withdrawals for industrial/commercial use began about 1970 and increased from about $0.1 \mathrm{Mgal} / \mathrm{d}$ in 1971 to nearly 0.3 $\mathrm{Mgal} / \mathrm{d}$ in 1979, before declining to about $0.1 \mathrm{Mgal} / \mathrm{d}$ in 1980. See appendix for ground-water withdrawal data for each large user: User's name, appropriation permit number, source aquifer, location on the Maryland Grid Coordinate System, average daily pumpage, and year pumping began.

The percentages of the total amount of ground water withdrawn for domestic, military, water supplier, and industrial/commercial uses for 1950, 1960, 1970, and 1980 are shown in figure 21. Domestic use comprised a significant portion of the total pumpage for all the years shown. Military use accounted for 42 percent of total ground water withdrawn in 1950, but by 1980 the percentage had dropped to only 4.6 percent. Withdrawals for industrial/commercial use began in the early 1970's and, by 1980, comprised about 5 percent of the total.

\section{Major Aquifers}

Many domestic withdrawals in Calvert County were from shallow wells (from about 15 to $45 \mathrm{ft}$ deep) tapping the surficial aquifer. Deeper aquifers, including the Piney Point, Aquia, and Magothy, were more widely used by large users. Large user withdrawals by aquifer from 1940 through 1980 are shown in figure 22.
Pumpage from the Piney Point began in 1947, with users withdrawing less than $0.01 \mathrm{Mgal} / \mathrm{d}$. However, during the following years, withdrawals increased and by 1980 were about $0.17 \mathrm{Mgal} / \mathrm{d}$. Large withdrawals from the Aquia aquifer, the greatest supplier of ground water in the county, began in 1941 and averaged about 0.80 Mgal/d through 1950, declining to just more than 0.2 $\mathrm{Mgal} / \mathrm{d}$ in 1960 . By 1980 , however, withdrawals had increased again to about $0.6 \mathrm{Mgal} / \mathrm{d}$. The Magothy aquifer was not used as a source of water supply by large users until 1971. Withdrawals at that time were about $0.04 \mathrm{Mgal} / \mathrm{d}$ and increased to more than $0.10 \mathrm{Mgal} / \mathrm{d}$ by 1980.

\section{Locations of Large Ground-Water Withdrawals}

The locations of large ground-water withdrawals in Calvert County for 1950,1960,1970, and 1980 are shown in figure 23. Table 5 presents water-use data for the large users located within a particular grid block for the year indicated on the map. In 1950, heaviest pumpage by large users was located in the northeastern and extreme southern parts of the county. The maps for 1960 and 1970 show several new locations of large withdrawals, particularly in the central and southeastern areas. By 1980, the distribution was widely scattered throughout the county.

The locations of withdrawals from the aquifers supplying large users in Calvert County (described in table 5 and fig. 23) are shown in figure 24. Use of the Piney Point aquifer by large users began in the 1950's and was located mainly in the east-central and southeastern parts of the county. The Aquia was the only aquifer that supplied large users in 1950. Increased use of the aquifer as a source for large quantities of water is shown on the maps for 1960,1970, and 1980. The Magothy was the deepest aquifer used as of 1980 , and withdrawals from it remained solely in the northernmost part of the county. 


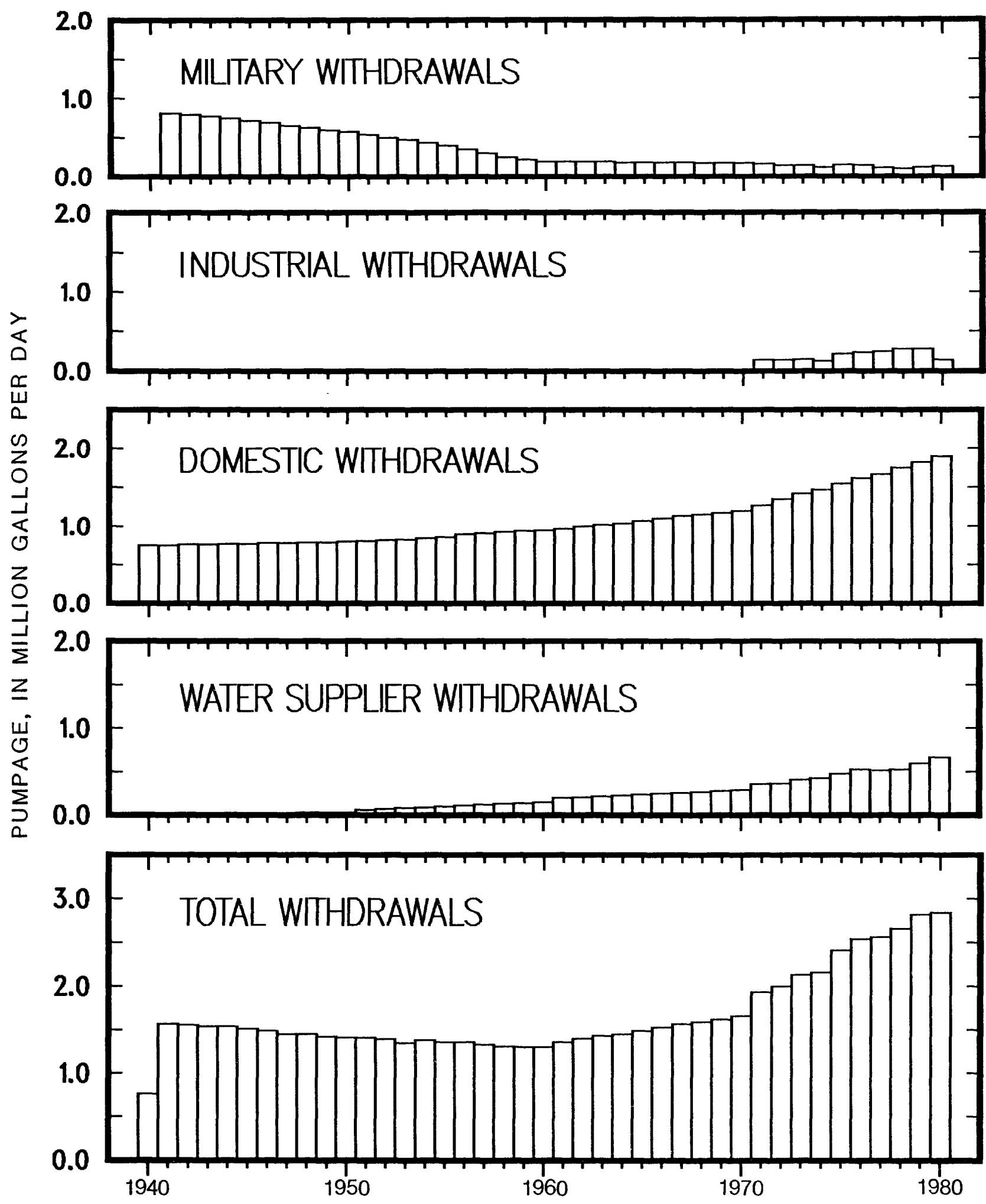

Figure 20.-- Ground-water withdrawals by use in Calvert County from 1940 through 1980. 


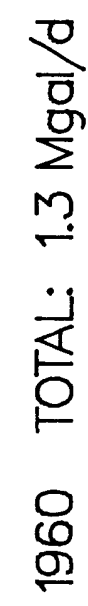

윰

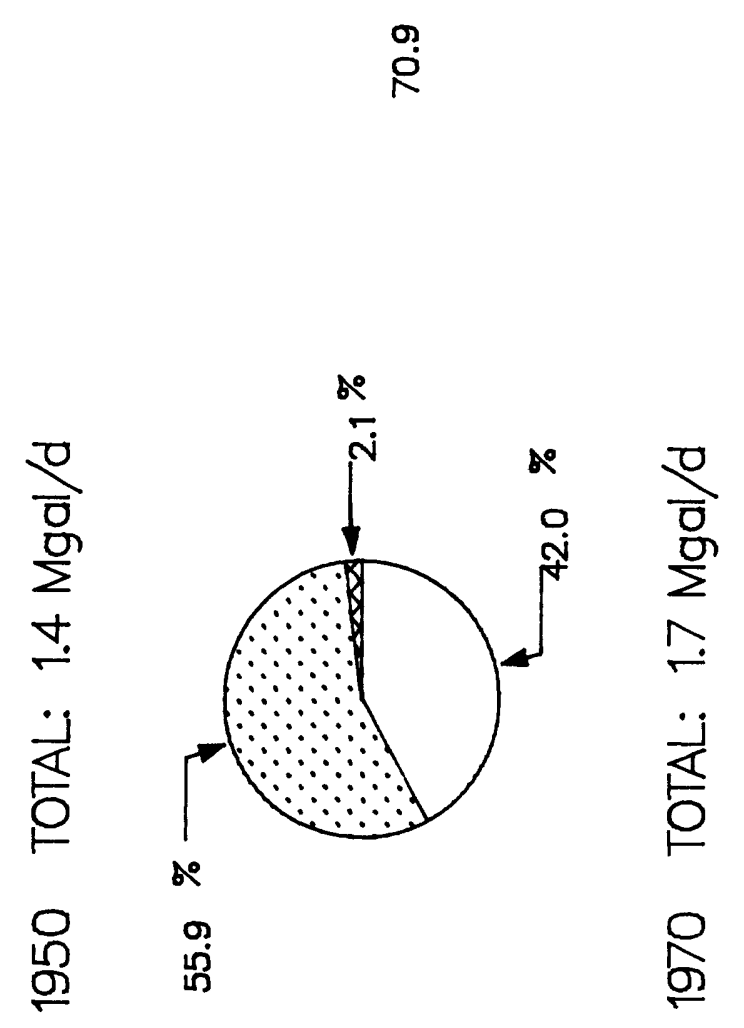

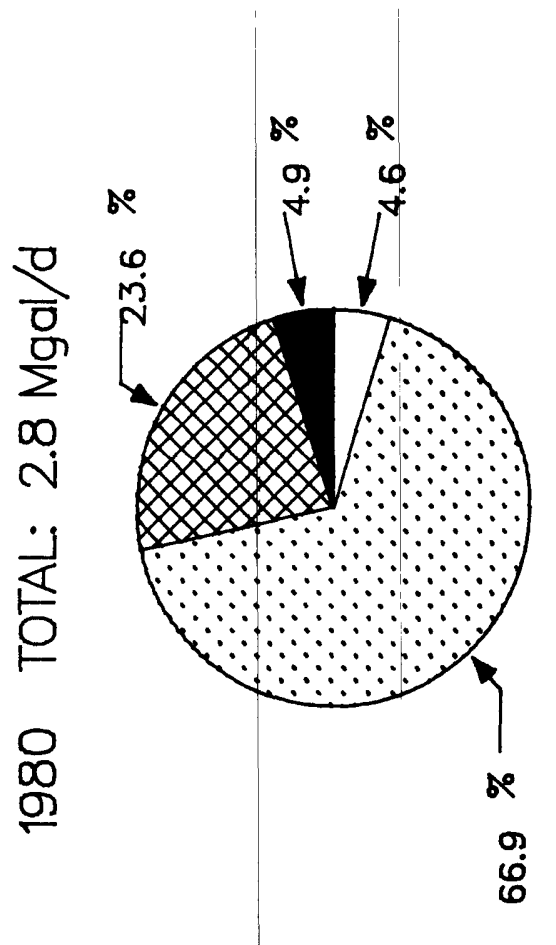

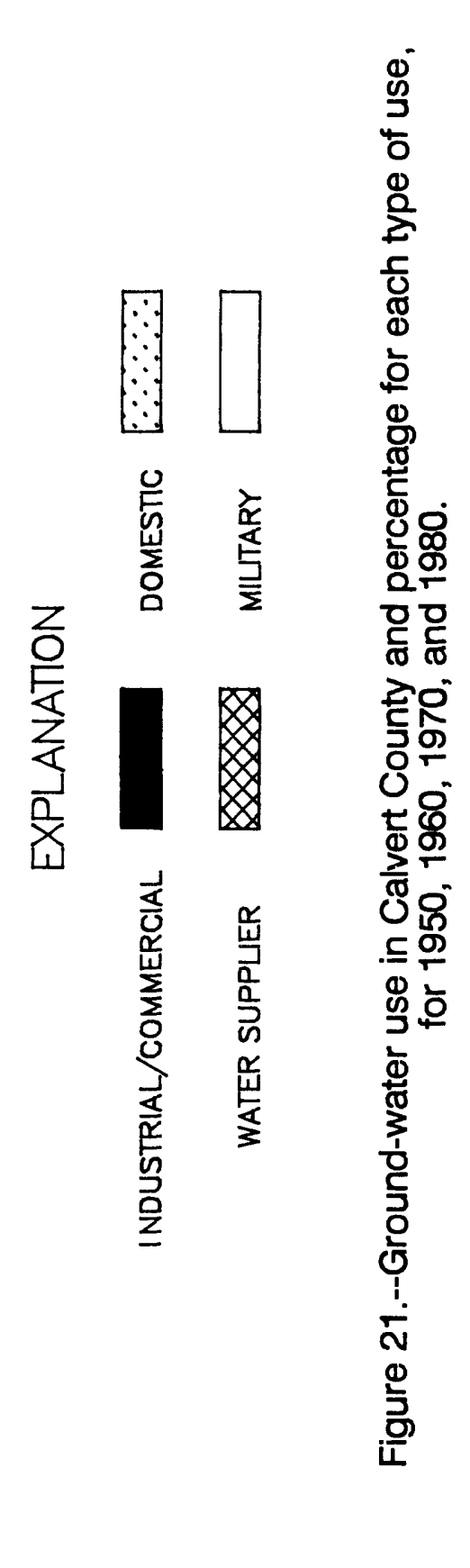




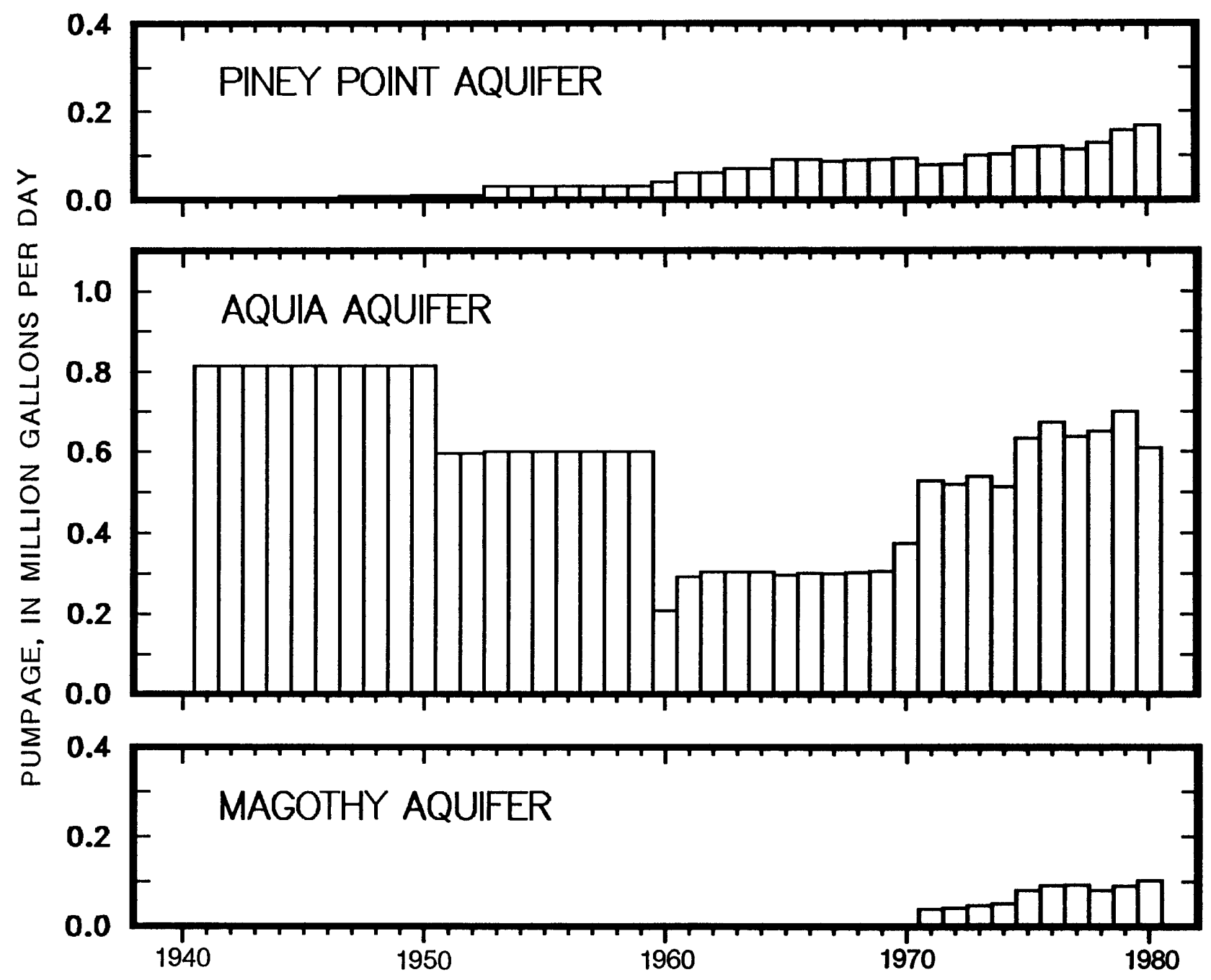

Figure 22.--Large ground-water withdrawals by aquifers in Calvert County from 1940 through 1980. 


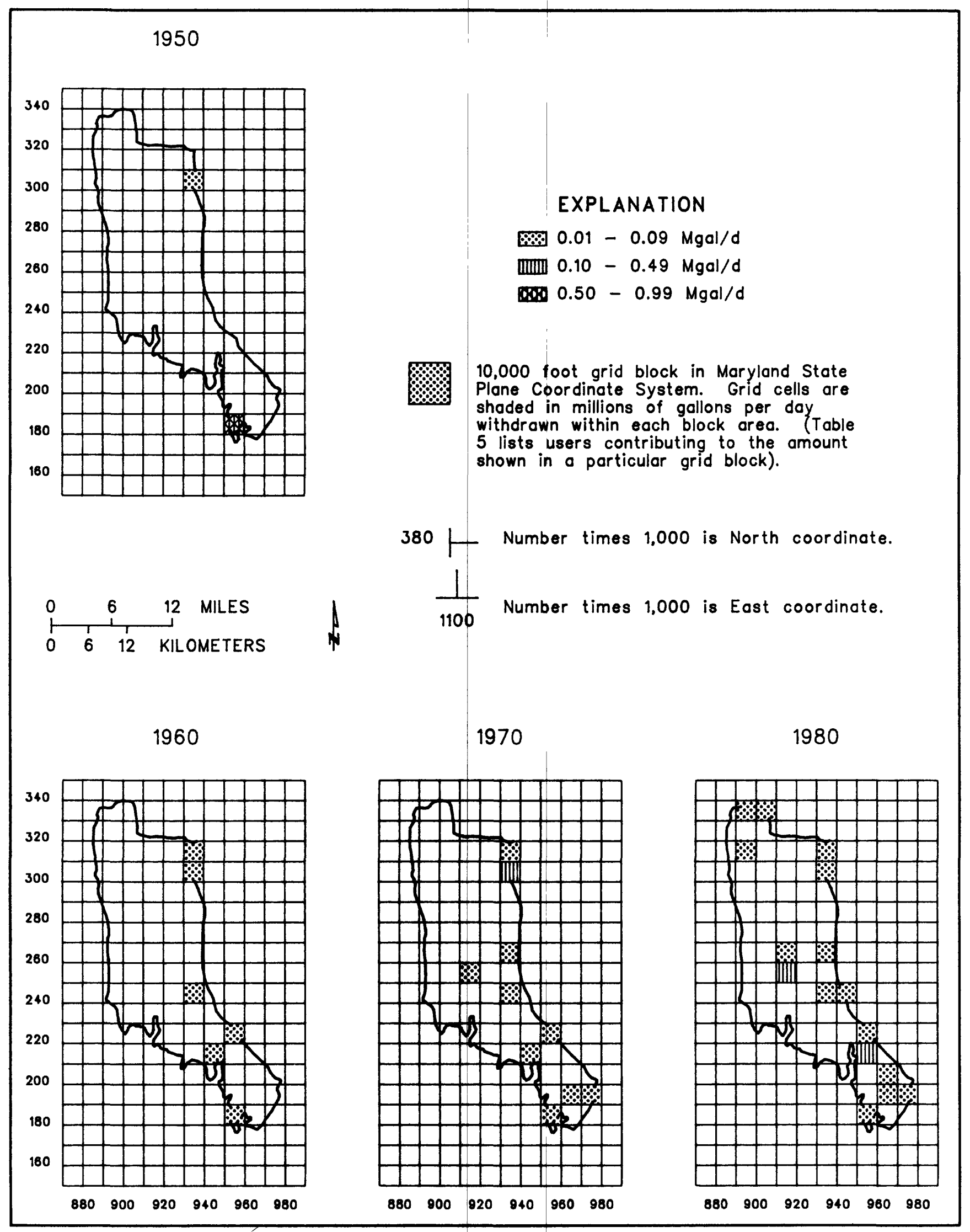

Figure 23.--Locations of large ground-water withdrawals in Calvert County for 1950, 1960, 1970, and 1980. 
Table 5.--Large ground-water users in Calvert County in 1950, 1960, 1970, and 1980, sumnarized by the Marylend Grid Coordinate Syatem

\begin{tabular}{|c|c|c|c|c|}
\hline Year & Grid block & User & $\begin{array}{l}\text { umpage } \\
\text { (sal/d) }\end{array}$ & Aquil fer \\
\hline 1950 & $\begin{array}{ll}\text { N180 } & \mathbf{E} 950 \\
\text { N300 } & \mathbf{E} 930\end{array}$ & $\begin{array}{l}\text { U.s. Navy, Solomons } \\
\text { U.S. Navy, Randle Clifes }\end{array}$ & $\begin{array}{r}0.75 \\
.06\end{array}$ & $\begin{array}{l}\text { Aquila } \\
\text { Aqquia }\end{array}$ \\
\hline 1980 & $\begin{array}{ll}\text { N180 } & E 950 \\
N 210 & \mathrm{E940} \\
\text { N220 } & \mathrm{E} 950 \\
\text { N240 } & \mathrm{E} 930 \\
\text { N300 } & \mathrm{E} 930 \\
\text { N310 } & \mathrm{E} 930\end{array}$ & $\begin{array}{l}\text { U.S. Navy, Solomons } \\
\text { White Sands Corporation } \\
\text { Lons Beach Water, Calvert water ayatem } \\
\text { Scientist Cliffs Service Company } \\
\text { U.S. Navy, Randle Cliffs } \\
\text { Ches apeake Beach water system }\end{array}$ & $\begin{array}{l}0.09 \\
.01 \\
.02 \\
.02 \\
.06 \\
.01\end{array}$ & $\begin{array}{l}\text { Aquia } \\
\text { Pinoy Point } \\
\text { Aquia } \\
\text { Pinoy Point } \\
\text { Aquia } \\
\text { Aquia }\end{array}$ \\
\hline 1870 & $\begin{array}{ll}N 180 & E 950 \\
N 190 & E 960 \\
N 190 & E 970 \\
N 210 & E 940 \\
N 220 & E 950 \\
N 240 & E 930 \\
N 250 & E 910 \\
N 260 & E 930 \\
N 300 & E 930 \\
N 310 & E 930\end{array}$ & $\begin{array}{l}\text { U.S. Navy, Solomons } \\
\text { Chesapeake Ranch Water Company } \\
\text { do. } \\
\text { White Sands Corporation } \\
\text { Lons Beach Water, Calvert water system } \\
\text { do. } \\
\text { Scientist Ciffs Service Company } \\
\text { Prince Frederick wator system } \\
\text { A.I.Cassoll Utillty Corporation } \\
\text { U.S. Navy, Randle Cliffs } \\
\text { Chesapeake Beach water system }\end{array}$ & $\begin{array}{l}0.08 \\
.02 \\
.03 \\
.01 \\
.02 \\
.03 \\
.02 \\
.09 \\
.01 \\
.10 \\
.03\end{array}$ & $\begin{array}{l}\text { Aquia } \\
\text { Piney Point } \\
\text { Aquia } \\
\text { Piney Point } \\
\text { Aquia Point } \\
\text { Piney Point } \\
\text { Piney Point } \\
\text { Aquia } \\
\text { Aquia } \\
\text { Aquia } \\
\text { Aquia }\end{array}$ \\
\hline 1980 & $\begin{array}{ll}\text { N180 } & E 950 \\
\text { N190 } & E 960 \\
\text { N190 } & E 970 \\
\text { N200 } & E 960 \\
\text { N210 } & E 950 \\
\text { N220 } & E 950 \\
\text { N240 } & E 930 \\
\text { N240 } & E 940 \\
\text { N250 } & E 910 \\
\text { N260 } & E 910 \\
\text { N260 } & E 930 \\
\text { N300 } & E 930 \\
\text { N310 } & E 890 \\
\text { N310 } & E 930 \\
\text { N330 } & E 890 \\
\text { N330 } & E 900\end{array}$ & 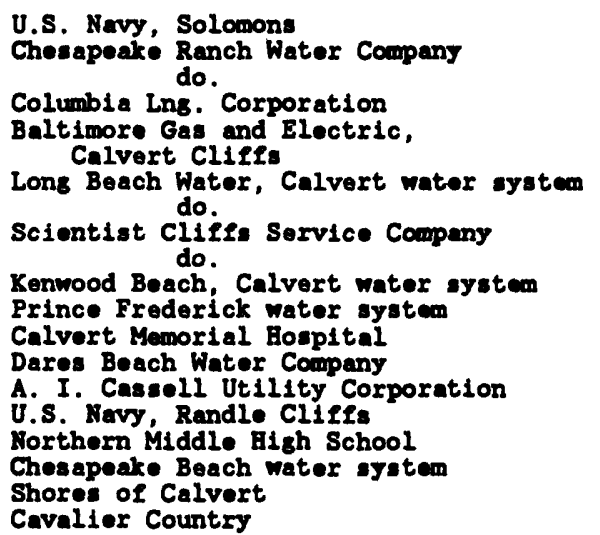 & $\begin{array}{l}0.09 \\
.03 \\
.09 \\
.01 \\
.12 \\
.02 \\
.06 \\
.03 \\
.01 \\
.02 \\
.10 \\
.03 \\
.03 \\
.04 \\
.04 \\
.02 \\
.05 \\
.04 \\
.05\end{array}$ & $\begin{array}{l}\text { Aquia } \\
\text { Piney Point } \\
\text { Aquia } \\
\text { Aquia } \\
\text { Aquia } \\
\text { Aquia } \\
\text { Piney Point } \\
\text { Piney Point } \\
\text { Aquia } \\
\text { Piney Point } \\
\text { Aquia } \\
\text { Aquia } \\
\text { Piney Point } \\
\text { Aquia } \\
\text { Aquia } \\
\text { Magothy } \\
\text { Aquia } \\
\text { Magothy } \\
\text { Magothy }\end{array}$ \\
\hline
\end{tabular}




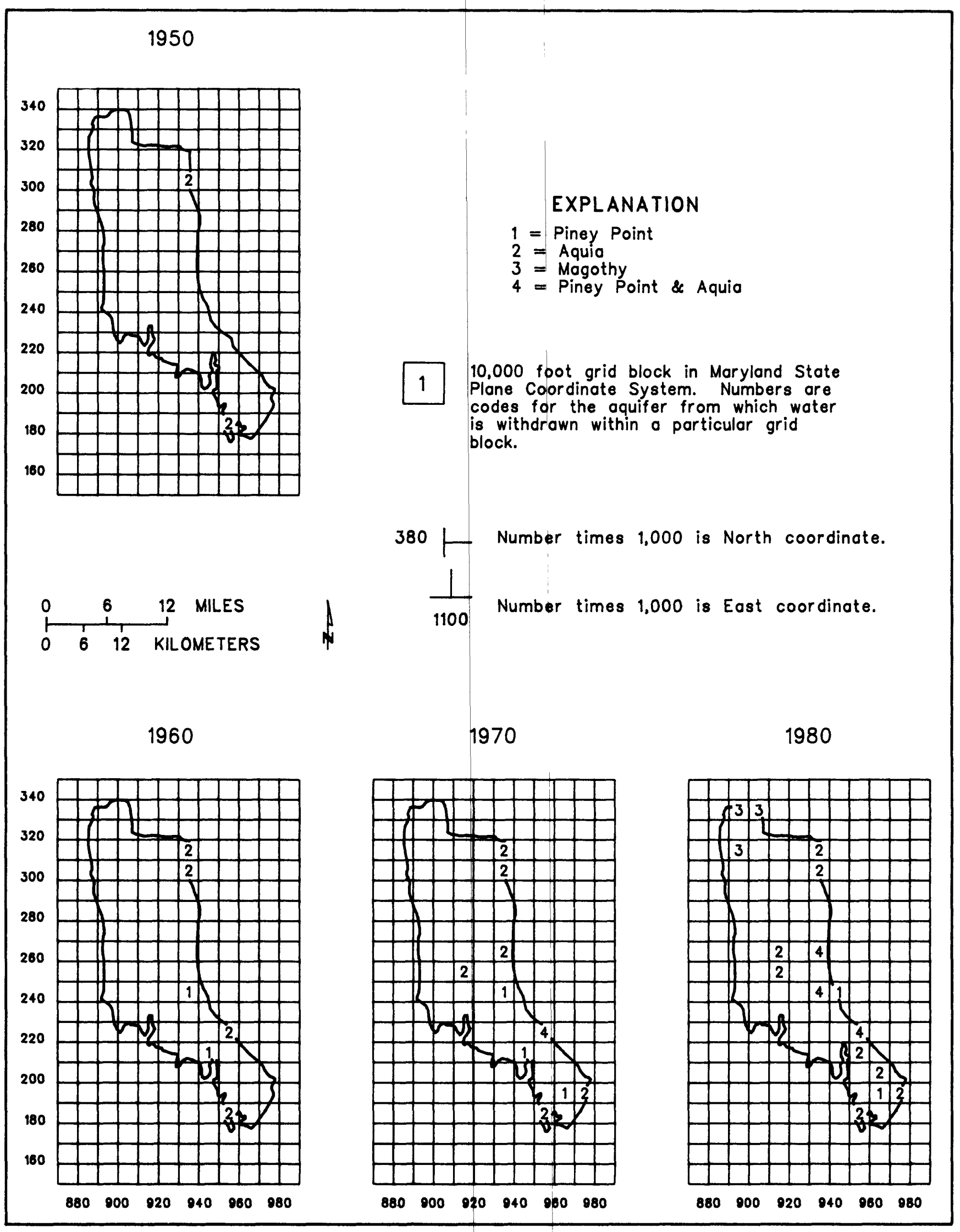

Figure 24.--Locations of large ground-water withdrawals by aquifers in Calvert County for $1950,1960,1970$, and 1980. 


\section{CAROLINE COUNTY}

Ground-water use in Caroline County from 1950 through 1980 is shown in figure 25 . In 1950, the amount of ground water withdrawn was approximately 3.3 $\mathrm{Mgal} / \mathrm{d}$ compared to withdrawals of nearly $7.1 \mathrm{Mgal} / \mathrm{d}$ in 1980. This represents an increase of 116 percent for the three decades. During that time, the amount of water withdrawn for domestic and water supplier uses remained relatively constant. However, a decline is indicated in the amount of water withdrawn for industrial/commercial use (from about $1.7 \mathrm{Mgal} / \mathrm{d}$ in 1950 to $0.4 \mathrm{Mgal} / \mathrm{d}$ in 1980). This decline is due largely to the closing of several canneries in the early 1970's (see appendix). An increase in the amount of ground water used for irrigation (from about $0.06 \mathrm{Mgal} / \mathrm{d}$ in 1954 to more than $3.5 \mathrm{Mgal} / \mathrm{d}$ in 1980) is also shown. The use of ground water for irrigation by large users in the county began in the mid-1950's. Although there have been no precise measurements of the amounts of water withdrawn by individual irrigators, methods of collecting and reporting these data have improved since that time; however, the most reliable data are from 1970 to 1980. See appendix for ground-water withdrawal data for each large user: User's name, appropriation permit number, source aquifer, location on the Maryland Grid Coordinate System, average daily pumpage, and year pumping began.

The percentages of the total amount of ground water withdrawn for domestic, water supplier, industrial/commercial, and irrigation uses for 1950, 1960, 1970 , and 1980 are shown in figure 26. It is interesting to note that in 1950, industrial/commercial use comprised about 50 percent of the total ground water withdrawn; in 1980, however, this category of use dropped to only 6 percent. Withdrawals for water supplier and domestic use remained fairly constant for the 4 years shown. Irrigation use increased from about 6 percent in 1960 to 50 percent in 1980.

\section{Major Aquifers}

The surficial (Quaternary and Columbia), lower Chesapeake, and Piney Point aquifers were most heavi- ly pumped by large users from 1950 through 1980 in Caroline County (fig. 27). Withdrawals from the surficial aquifer were less than $0.1 \mathrm{Mgal} / \mathrm{d}$ from 1950 through 1975 , increasing to about $0.5 \mathrm{Mgal} / \mathrm{d}$ in 1976 . In 1980 , pumpage from these aquifers reached about $0.6 \mathrm{Mgal} / \mathrm{d}$.

The lower Chesapeake aquifer in the lower Chesapeake Group includes several water-bearing units which were used extensively in the county. These include the Frederica (and equivalent Choptank), Federalsburg, and Cheswold aquifers. As figure 27 shows, this group of aquifers supplied the greatest amount of water to large users. In 1969, withdrawals peaked at approximately $2.0 \mathrm{Mgal} / \mathrm{d}$. However, beginning in 1970, use of the aquifers declined primarily due to the closing of several canneries which pumped water from these sands (see appendix). By 1980, withdrawals had been reduced to about $0.8 \mathrm{Mgal} / \mathrm{d}$. Pumpage from the Piney Point increased gradually from about 0.3 $\mathrm{Mgal} / \mathrm{d}$ in 1950 to just more than $0.5 \mathrm{Mgal} / \mathrm{d}$ in 1980.

\section{Locations of Large Ground-Water Withdrawals}

The lecations of withdrawals by large users in Caroline County for 1950, 1960, 1970, and 1980 are shown in figure 28. Table 6 presents water-use data for the large users located within particular grid blocks for the year indicated on the map. The figure shows that the locations of large withdrawals did not change or increase significantly for any of the years presented.

The locations of withdrawals from individual aquifers supplying the large users in Caroline County (described in table 6 and fig. 28) are shown in figure 29. Withdrawals from the surficial aquifer remained solely in the southernmost part of the county. The use of the water-bearing units of the lower Chesapeake Group was distributed throughout the county. Use of the Piney Point aquifer was limited to the central and northcentral part of the county in 1950, but extended to the south-central part in 1960, 1970, and 1980. 


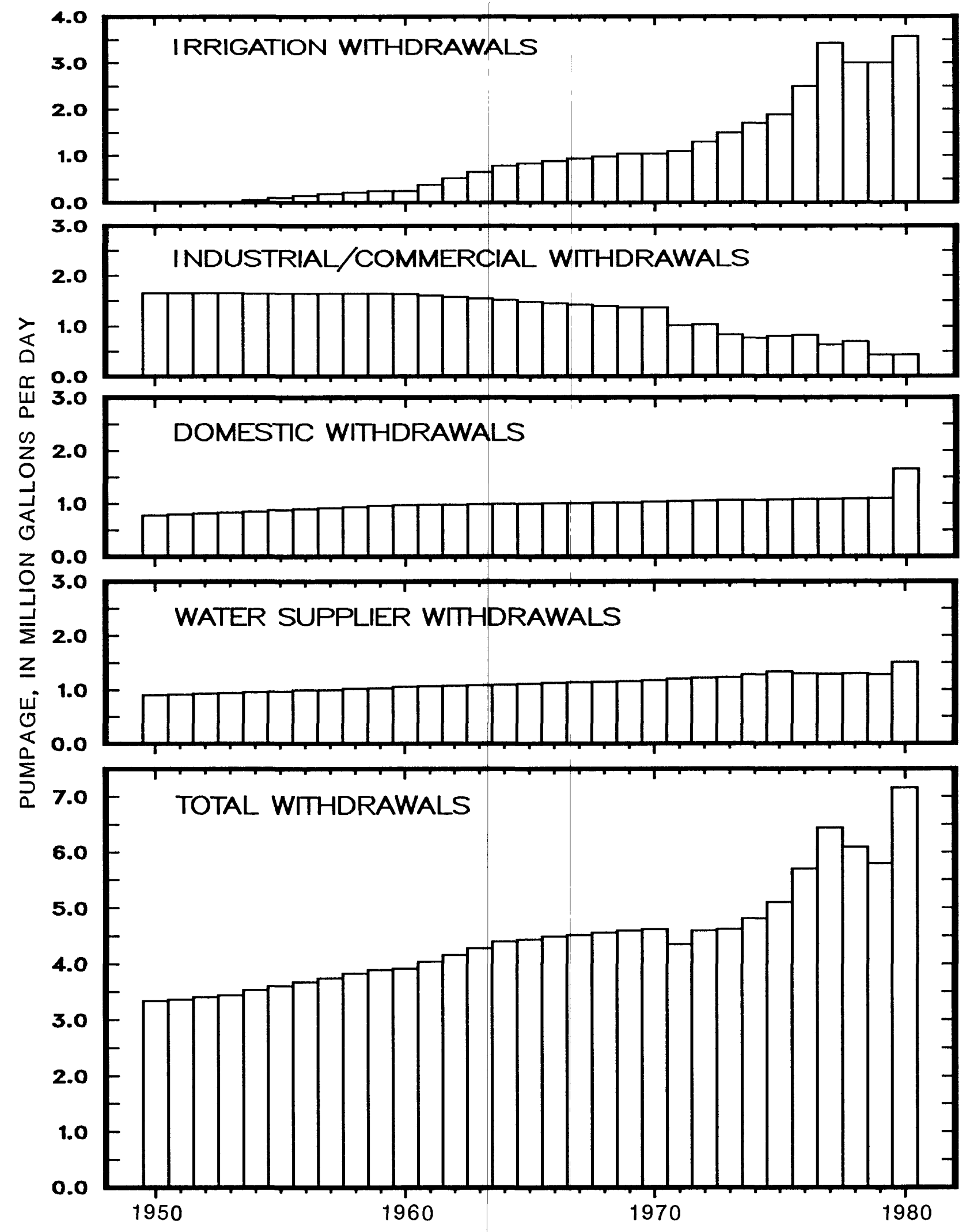

Figure 25.--Ground-water withdrawals by use in Caroline County from 1950 through 1980. 


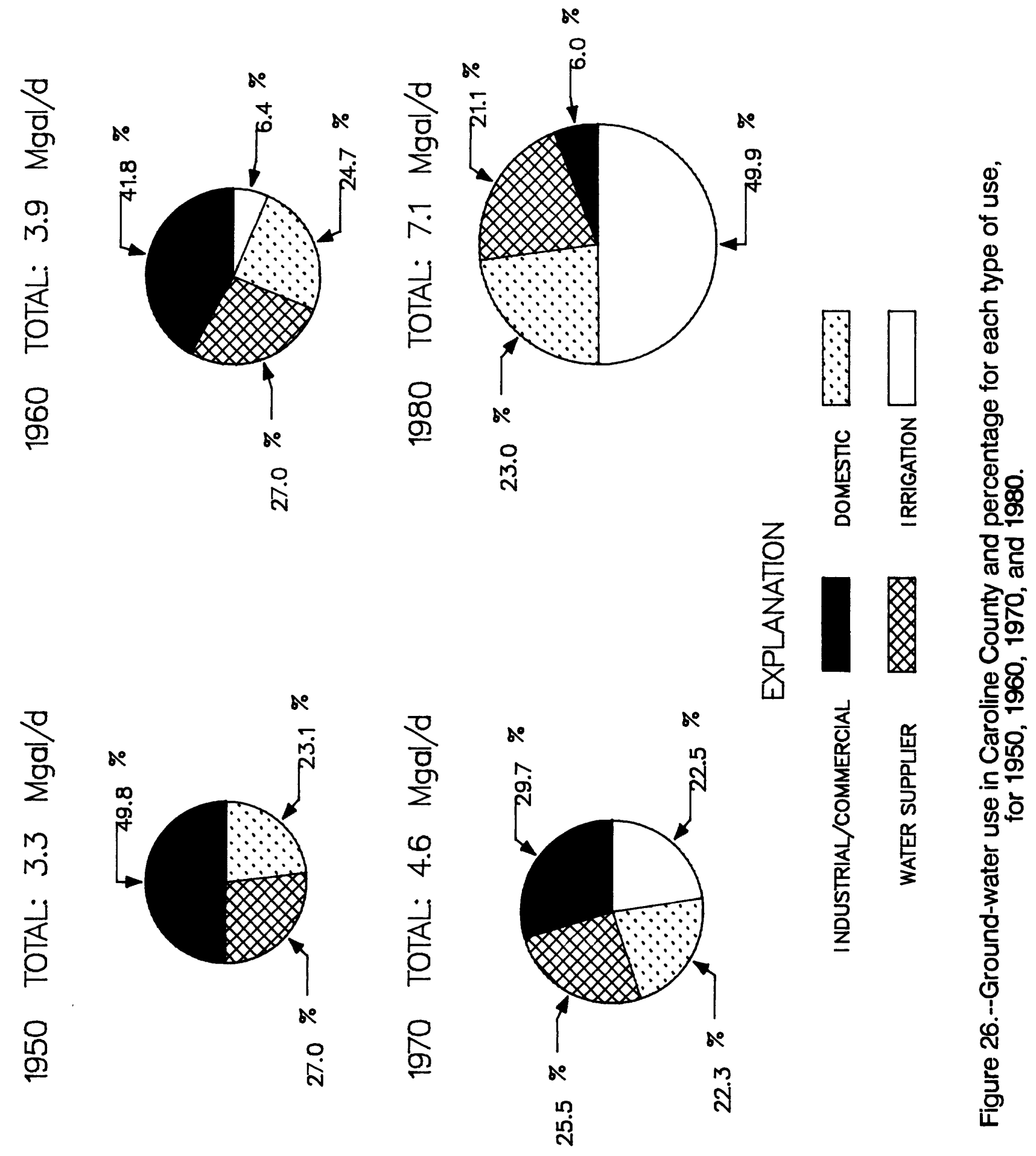




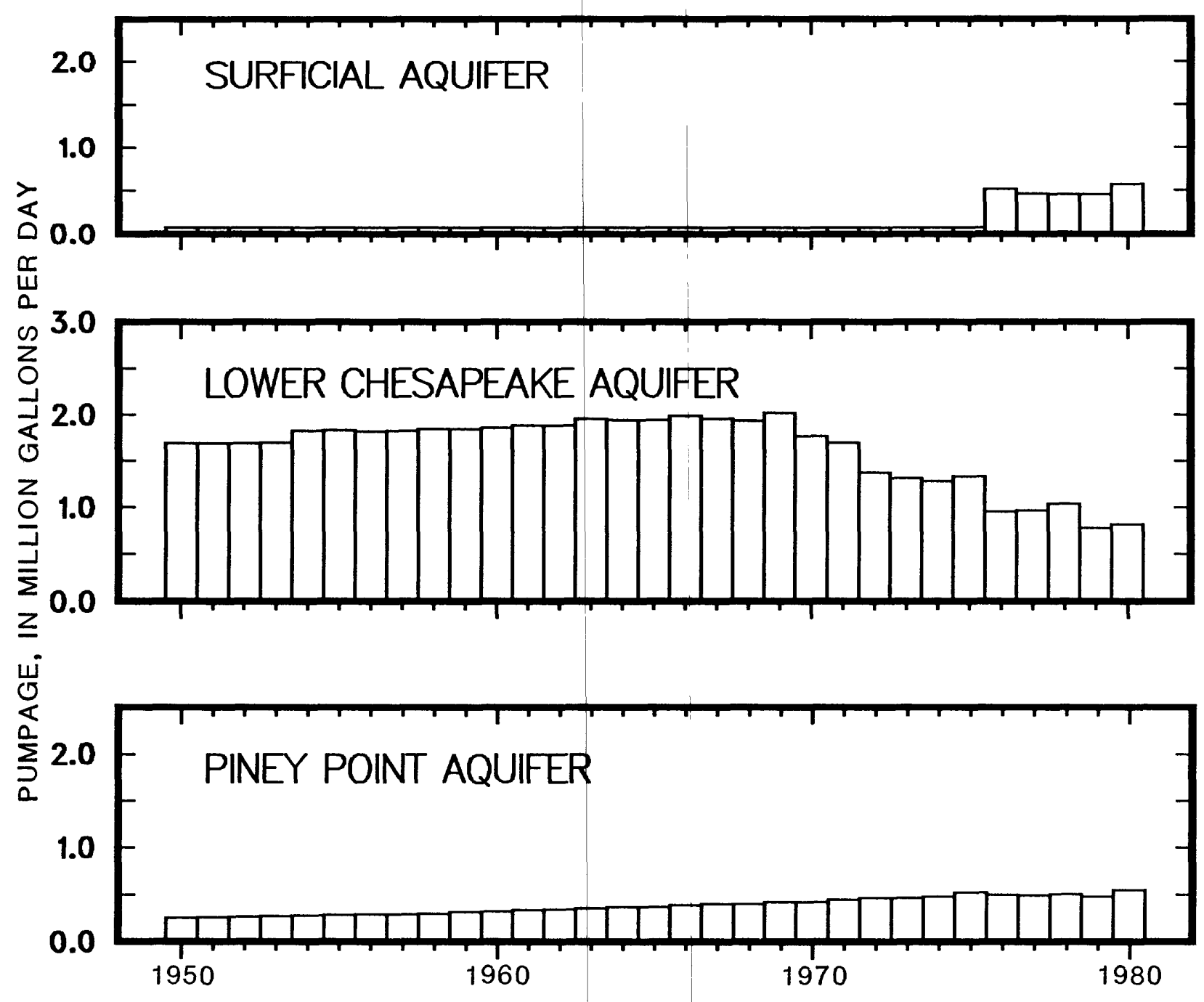

Figure 27.--Large ground-water withdrawals by aquifers in Caroline County from 1950 through 1980. 
1950

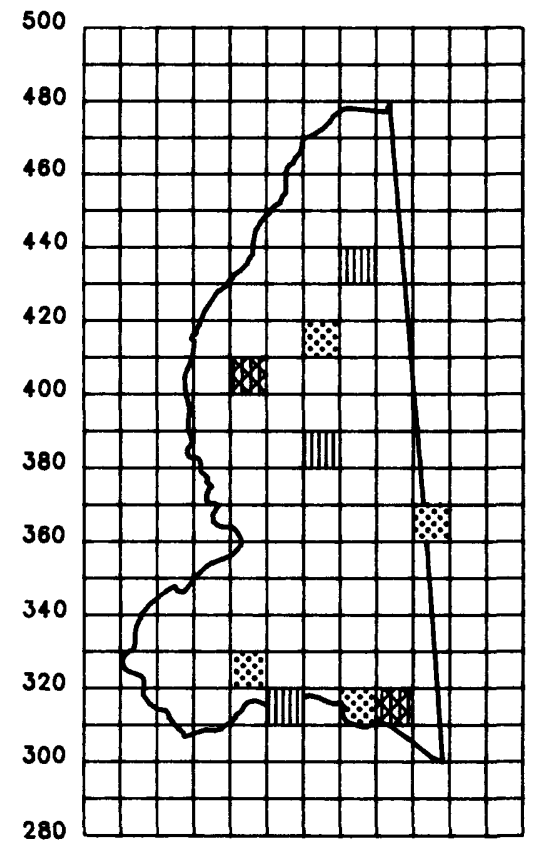

\begin{tabular}{lllll|}
0 & & 6 & 12 & MILES \\
1 & 1 & 1 & 12 & KILOMETERS
\end{tabular}

1960

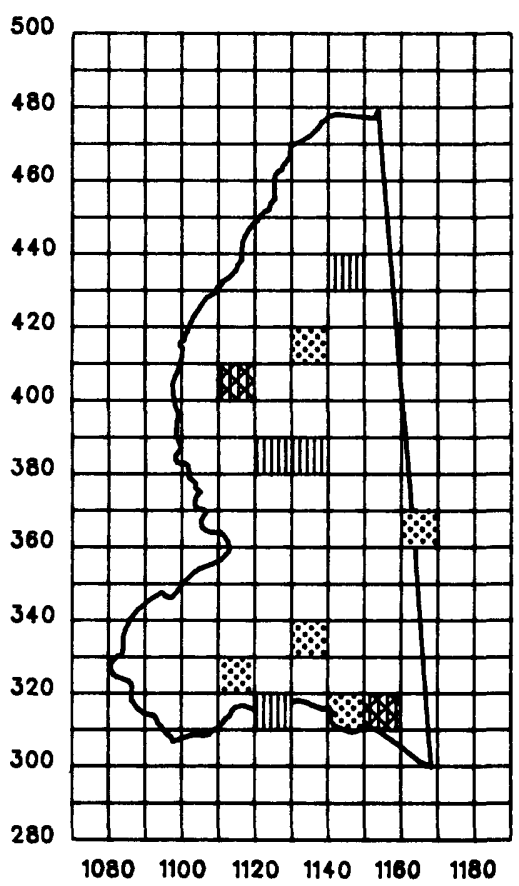

\section{EXPLANATION}

$0.01-0.09 \mathrm{Mgal} / \mathrm{d}$

而而 $0.10-0.49 \mathrm{Mgal} / \mathrm{d}$

$0.50-0.99 \mathrm{Mgal} / \mathrm{d}$ 10,000-foot grid block in Maryland State Plane Coordinate System. Grid cells ore shaded in millions of gallons per day withdrawn within each block orea. (Table 6 lists users contributing to the amount shown in a particular grid block).

380 Number times 1,000 is North coordinate.

Number times 1,000 is East coordinate.
1970

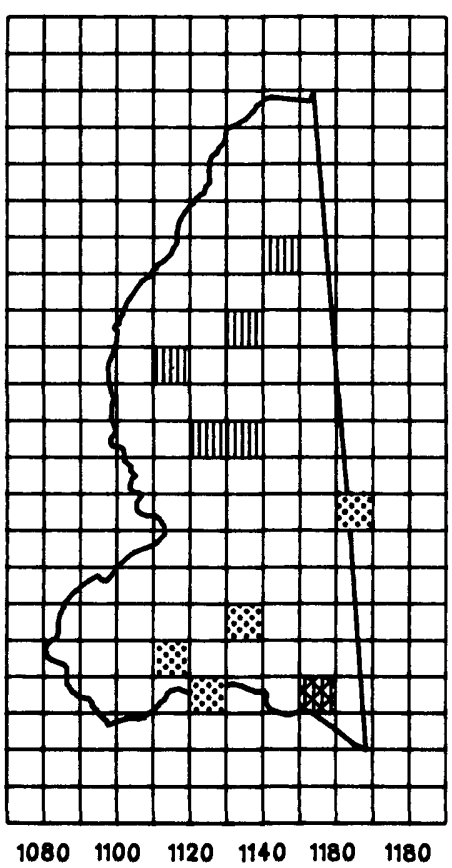

1980

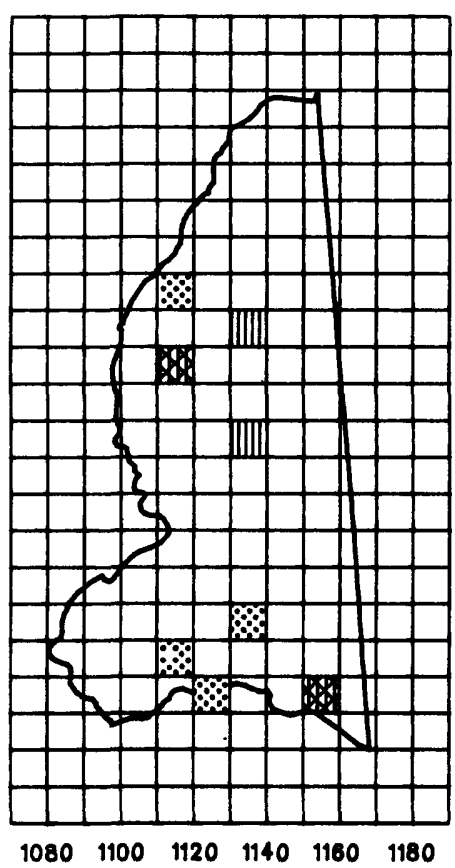

Figure 28.--Locations of large ground-water withdrawals in Caroline County for 1950, 1960, 1970, and 1980. 
Table 6.--Large ground-water users in Caroline County in 1950, 1960, 1970, and 1980, summarized by the Maryland Grid Coordinate System

\begin{tabular}{|c|c|c|c|c|}
\hline Year & Grid block & User & $\begin{array}{l}\text { Pumpage } \\
\text { (Msal/d) }\end{array}$ & Aquifer \\
\hline 1950 & $\begin{array}{ll}N 310 & E 1120 \\
N 310 & E 1140 \\
N 310 & E 1150 \\
N 320 & E 1110 \\
N 360 & E 1160 \\
N 380 & E 1130 \\
N 400 & E 1110 \\
N 410 & E 1130 \\
N 430 & E 1140\end{array}$ & $\begin{array}{l}\text { John N. Wright, Jr. } \\
\text { John N. Wright, Jr., Incorporated } \\
\text { Wheatley Canning Company } \\
\text { Federalsburg, Tom of } \\
\text { Maryland Plastics } \\
\text { Preaton, Town of } \\
\text { Nuttle Canning Company } \\
\text { Denton, Town of } \\
\text { Ridgely, Town of } \\
\text { Saulsbury Brothers, Incorporated } \\
\text { Greensboro, Town of } \\
\text { T. Noble Jarrell Canning coupany } \\
\text { Cooklyn Dairies }\end{array}$ & $\begin{array}{l}0.11 \\
.03 \\
.15 \\
.48 \\
.09 \\
.07 \\
.04 \\
.18 \\
.05 \\
.50 \\
.07 \\
.14 \\
.09\end{array}$ & $\begin{array}{l}\text { Federalsburg } \\
\text { Calvert } \\
\text { Calvert } \\
\text { Federalsburg } \\
\text { Calvert } \\
\text { Pleistocene } \\
\text { Federalsburg } \\
\text { Plney Point } \\
\text { Frederica } \\
\text { Quaternary } \\
\text { Piney Point } \\
\text { Quaternary } \\
\text { Choptank }\end{array}$ \\
\hline 1960 & $\begin{array}{ll}\text { N310 } & E 1120 \\
N 310 & E 1140 \\
N 310 & E 1150 \\
& \\
N 320 & E 1110 \\
N 330 & E 1130 \\
N 360 & E 1160 \\
N 380 & E 1120 \\
N 380 & E 1130 \\
N 400 & E 1110 \\
N 410 & E 1130 \\
N 430 & E 1140\end{array}$ & $\begin{array}{l}\text { John N. Wright, Jr. } \\
\text { John N. Wright, Jr., Incorporated } \\
\text { Wheatley Canning Company } \\
\text { Federalsburg, town of } \\
\text { Maryland Plastics } \\
\text { Preston, Town of } \\
\text { Northern and Denton Bigh Schoals } \\
\text { Nuttle Canning Company } \\
\text { Wilson Laurel Farms, Incorporated } \\
\text { Denton, Town of } \\
\text { Ridgely, Town of } \\
\text { Saulsbury Brothers, Incorporated } \\
\text { Greensboro, Town of } \\
\text { T. Noble Jarrell Canping Company } \\
\text { Cooklyn Dairies }\end{array}$ & $\begin{array}{l}0.11 \\
.03 \\
.15 \\
.49 \\
.09 \\
.07 \\
.01 \\
.04 \\
.12 \\
.21 \\
.09 \\
.50 \\
.10 \\
.14 \\
.09\end{array}$ & $\begin{array}{l}\text { Federalsburg } \\
\text { Calvert } \\
\text { Calvert } \\
\text { Federalsburg } \\
\text { Calvert } \\
\text { Pleistocene } \\
\text { Piney Point } \\
\text { Federalsburg } \\
\text { Choptank } \\
\text { Piney Point } \\
\text { Frederica } \\
\text { Quaternary } \\
\text { Piney Point } \\
\text { Quaternary } \\
\text { Choptank }\end{array}$ \\
\hline 1970 & $\begin{array}{ll}\text { N310 } & E 1120 \\
N 310 & E 1150 \\
N 320 & E 1110 \\
N 330 & E 1130 \\
N 360 & E 1160 \\
N 380 & E 1120 \\
N 380 & E 1130 \\
N 400 & E 1110 \\
& \\
N 410 & E 1130 \\
N 430 & E 1140\end{array}$ & $\begin{array}{l}\text { John N. Wright, Jr. } \\
\text { Wheatley Canning Company } \\
\text { Federalsburg, Town of } \\
\text { Maryland Plastics } \\
\text { Preston, Town of } \\
\text { Northern and Denton High Schools } \\
\text { do. } \\
\text { Nuttle Canning Company } \\
\text { Wilson Laurel Farms, Incorporated } \\
\text { Denton, Town of } \\
\text { Ridgely, Town of } \\
\text { Saulsbury Brothers, Incorporated } \\
\text { Grasonville Fisheries, Incorporated } \\
\text { Greensboro, town of } \\
\text { T. Noble Jarrell Canming Company } \\
\text { David M. King Cannins Company } \\
\text { Cooklyn Dairies }\end{array}$ & $\begin{array}{l}0.08 \\
.15 \\
.52 \\
.09 \\
.07 \\
.02 \\
.01 \\
.04 \\
.12 \\
.26 \\
.14 \\
.22 \\
.11 \\
.15 \\
.14 \\
.04 \\
.09\end{array}$ & $\begin{array}{l}\text { Federalsburs } \\
\text { Calvert } \\
\text { Federalsburs } \\
\text { Calvert } \\
\text { Pleistocene } \\
\text { Cheswold } \\
\text { Plney Point } \\
\text { Federalsburg } \\
\text { Choptank } \\
\text { Piney Point } \\
\text { Frederica } \\
\text { Quaternary } \\
\text { Frederica } \\
\text { Piney Polnt } \\
\text { Quaternary } \\
\text { Quaternary } \\
\text { Choptank }\end{array}$ \\
\hline 1980 & $\begin{array}{ll}N 310 & E 1120 \\
N 310 & \mathrm{E} 1150 \\
& \\
N 320 & \mathrm{E} 1110 \\
N 330 & \mathrm{E} 1130 \\
N 380 & \mathrm{E} 1130 \\
N 400 & \mathrm{E} 1110 \\
& \\
N 410 & \mathrm{E} 1130 \\
N 420 & \mathrm{E} 1110\end{array}$ & $\begin{array}{l}\text { John N, Wright, Jr. } \\
\text { Federalsburg, Town of } \\
\text { do. } \\
\text { Preston, Town of } \\
\text { Northern and Denton \#igh Schools } \\
\text { do. } \\
\text { Denton, Town of } \\
\text { Ridgely, Town of } \\
\text { Saulsbury Brothers, Incorporated } \\
\text { Grasonville Fisheries, Incorporated } \\
\text { Greensboro, Town of } \\
\text { The Benedictine School }\end{array}$ & $\begin{array}{l}0.06 \\
.17 \\
.50 \\
.07 \\
.02 \\
.02 \\
.36 \\
.19 \\
.24 \\
.13 \\
.17 \\
.02\end{array}$ & $\begin{array}{l}\text { Federalsburg } \\
\text { Federalsburg } \\
\text { Columbia } \\
\text { Pleistocene } \\
\text { Cheswold } \\
\text { Piney Point } \\
\text { Piney Point } \\
\text { Frederica } \\
\text { Quaternary } \\
\text { Frederica } \\
\text { Piney Point } \\
\text { Frederica }\end{array}$ \\
\hline
\end{tabular}




\section{0}
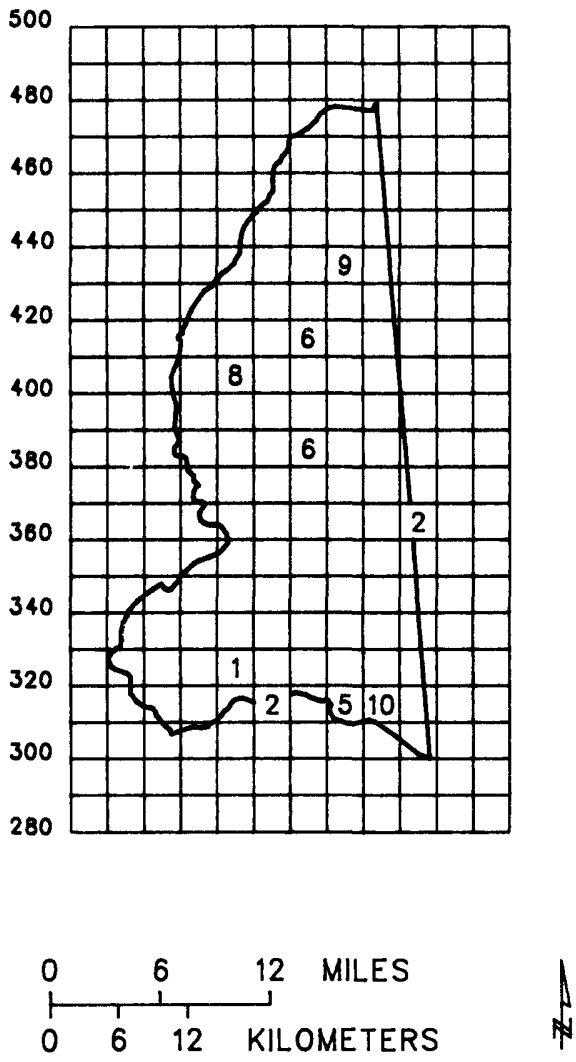

1960

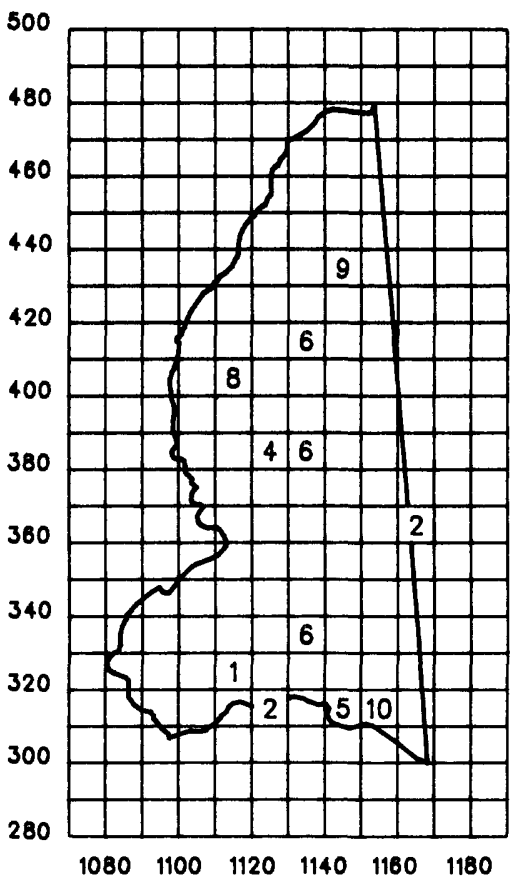

EXPLANATION

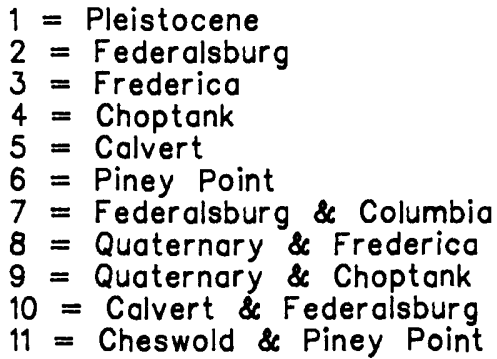

10,000-foot grid block in Maryland State Plane Coordinate System. Numbers are codes for the aquifer from which water is withdrawn within a particular grid block.

380 Number times 1,000 is North coordinate.

Number times 1,000 is East coordinate.
1970

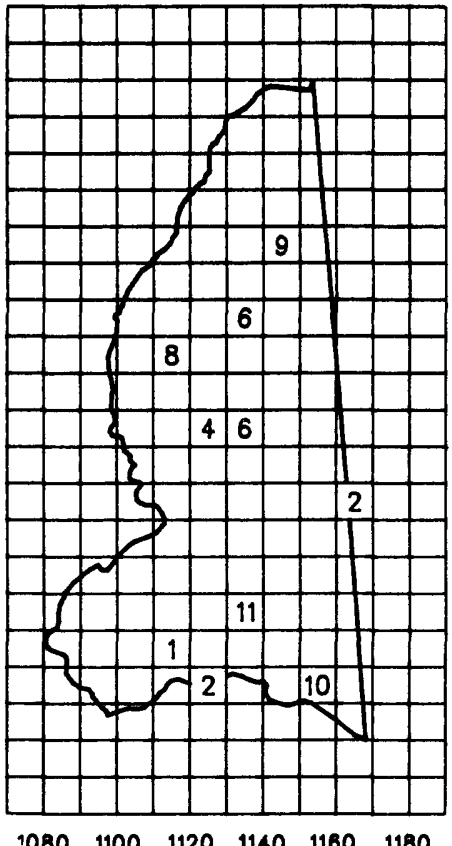

1980

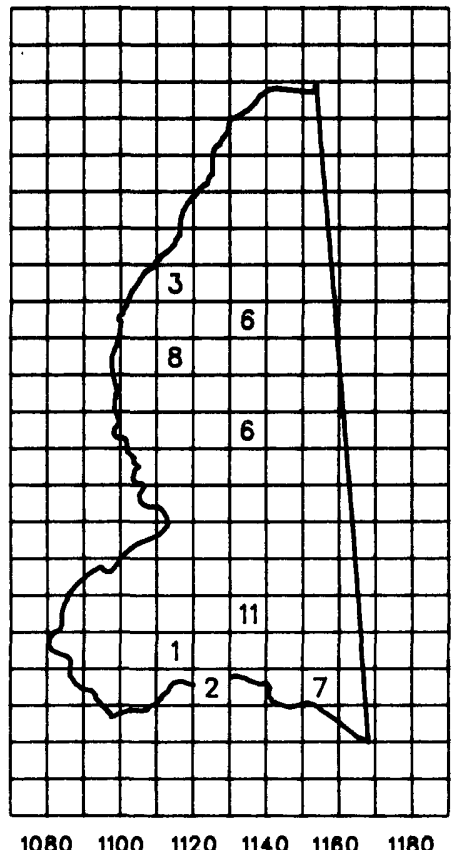

Figure 29.--Locations of large ground-water withdrawals by aquifers in Caroline County for 1950, 1960, 1970, and 1980. 


\section{CECIL COUNTY}

About one-half of Cecil County lies within the Coastal Plain. Ground- water use in the Coastal Plain area of Cecil County from 1950 through 1980 is shown in figure 30. In 1950, the amount of ground water withdrawn was approximately $0.7 \mathrm{Mgal} / \mathrm{d}$ compared to withdrawals of more than $2.0 \mathrm{Mgal} / \mathrm{d}$ in 1980 . This represents an increase of 186 percent for the three decades.

Since 1950 , water use increased in nearly every category. The largest use of ground water was for domestic use, increasing from about $0.6 \mathrm{Mgal} / \mathrm{d}$ in 1950 to nearly $1.3 \mathrm{Mgal} / \mathrm{d}$ in 1980 . Withdrawals for use by water suppliers showed an increase from about 0.1 $\mathrm{Mgal} / \mathrm{d}$ in 1950 to nearly $0.6 \mathrm{Mgal} / \mathrm{d}$ in 1980 ; water withdrawn for industrial/commercial use increased from less than $0.01 \mathrm{Mgal} / \mathrm{d}$ in 1950 to just more than 0.1 $\mathrm{Mgal} / \mathrm{d}$ in 1980. Water used for irrigation was estimated from available data and averaged about 0.02 Mgal/d from 1970 to 1980 . See appendix for groundwater withdrawal data for each user: User's name, appropriation permit number, source aquifer, location on the Maryland Grid Coordinate System, average daily pumpage, and year pumping began.

The percentages of the total amount of ground water withdrawn for domestic, water supplier, industrial/commercial, and irrigation users for 1950, 1960,1970 , and 1980 are shown in figure 31.

\section{Major Aquifers}

Many domestic withdrawals in the Coastal Plain area of Cecil County were from shallow wells (from about 15 to $45 \mathrm{ft}$ deep) tapping the surficial aquifer. Deeper aquifers, including the Magothy and the aquifers of the Potomac Group, were more widely used by large users. Large user withdrawals by aquifer from 1950 through 1980 are shown in figure 32. The use of the Magothy aquifer began about 1968 and, as of 1980, large-user withdrawals were limited to one water sup- plier (see appendix).

The water-yielding sand and gravel of the Patapsco and Patuxent Formations in the Cretaceous Potomac Group form the Patapsco and Patuxent aquifers (table 1). Where the aquifers are poorly differentiated in Cecil County, they are designated the Potomac aquifers. Figure 32 shows that the Potomac aquifers were the most important source of ground water for large users in the Coastal Plain part of the county, with withdrawals increasing from about $0.12 \mathrm{Mgal} / \mathrm{d}$ in 1950 to nearly $0.7 \mathrm{Mgal} / \mathrm{d}$ in 1980 .

\section{Locations of Large Ground-Water Withdrawals}

The locations of withdrawals by large users in the Coastal Plain area of Cecil County for 1950, 1960, 1970, and 1980 are shown in figure 33. Table 7 presents water-use data for the large users located within particular grid blocks for the year indicated on the map.

In 1950, the areas of greatest pumpage were located near the Fall Line and in the south-central part of the county. The successive maps show the increase of the areal distribution of large pumpage, and that by 1980, withdrawals were fairly evenly scattered throughout the Coastal Plain portion of the county.

The locations of withdrawals from individual aquifers supplying the large users in the Coastal Plain area of Cecil County (described in table 7 and fig. 33) are shown in figure 34. The Magothy aquifer was not used as a source of water for large users until after 1960 (see appendix). Its use remained limited to a water supplier located in the southern part of the county. The Potomac aquifers were the principal sources of ground water for large users as shown on each of the maps. A comparison of the maps for 1950 and 1980 shows that the areal distribution of use of the Potomac aquifers increased significantly. 


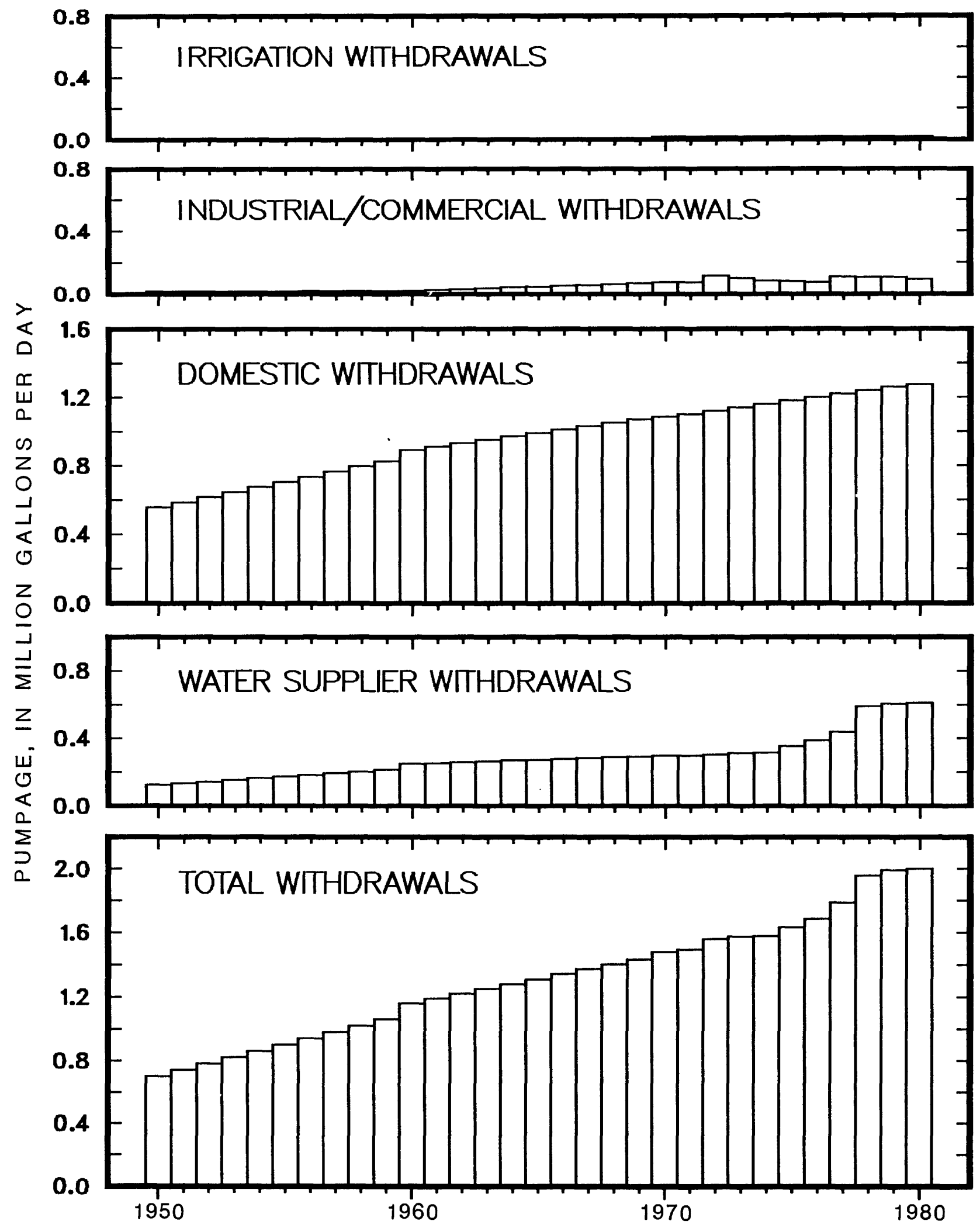

Figure 30.-- Ground-water withdrawals by use in the Coastal Plain area of Cecil County from 1950 through 1980. 


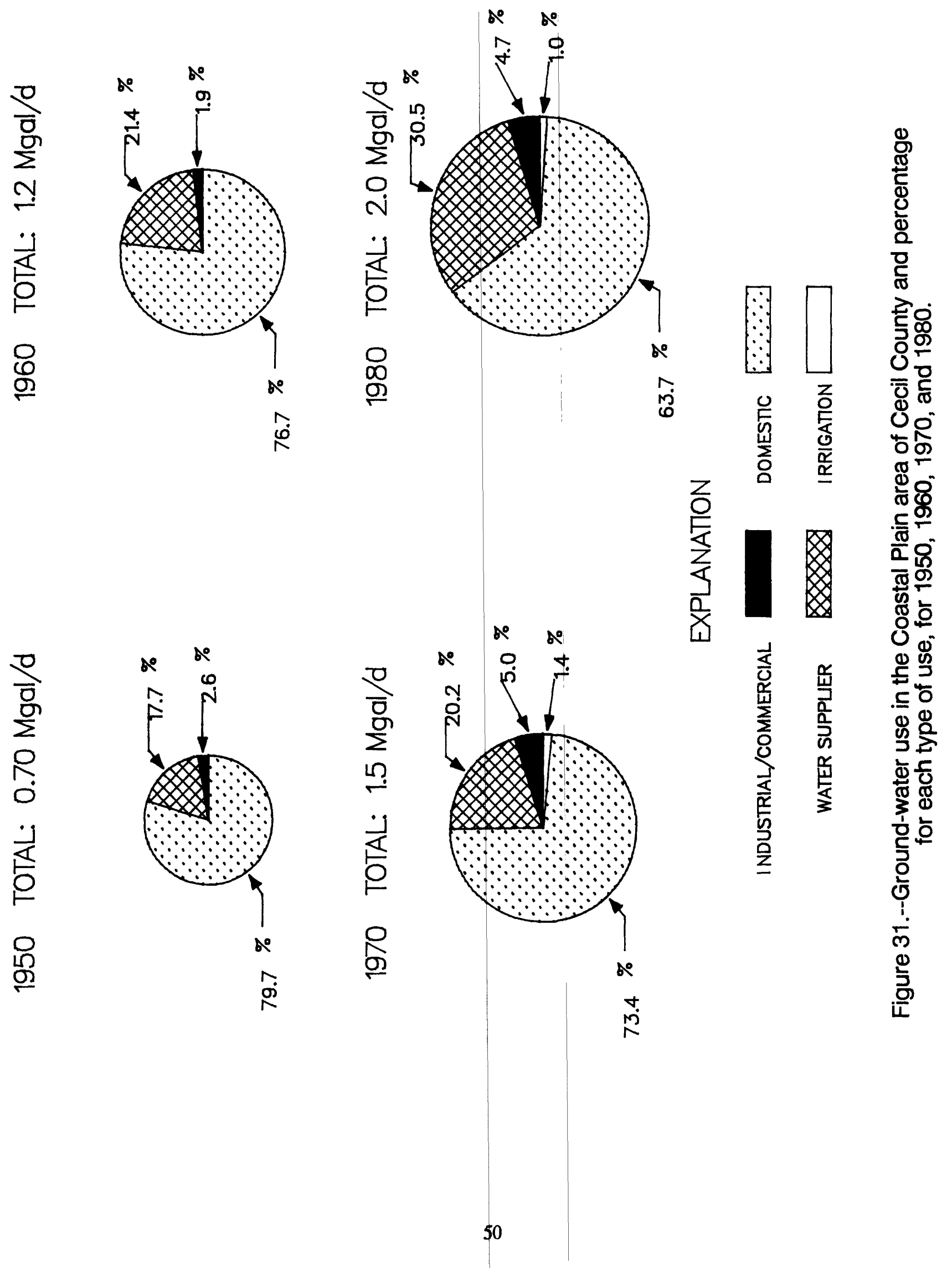



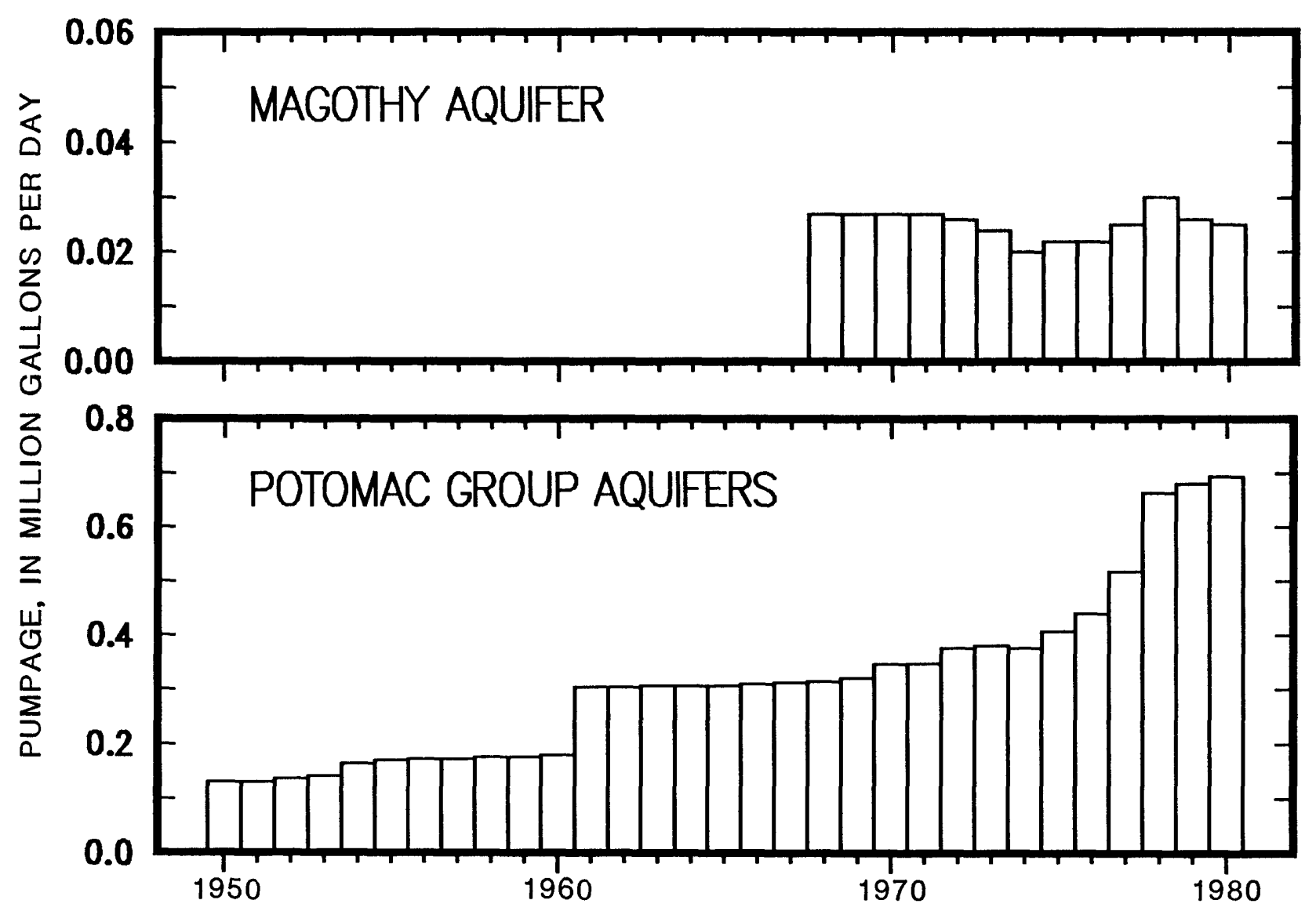

Figure 32.-- Large ground-water withdrawals by aquifers in the Coastal Plain area of Cecil County from 1950 through 1980. 


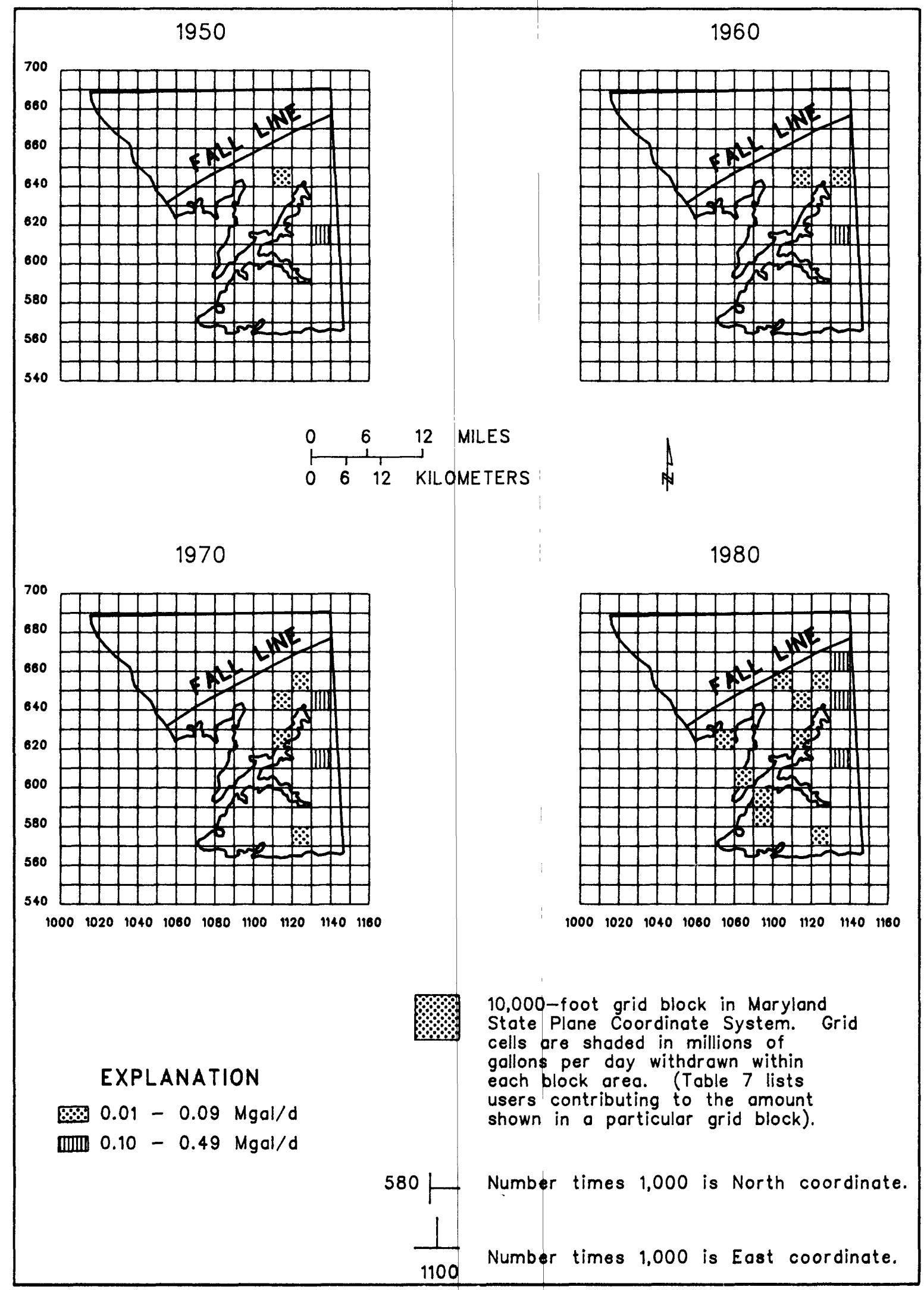

Figure 33.--Locations of large ground-water withdrawals in the Coastal Plain area of Cecil County for 1950, 1960, 1970, and 1980. 
Table 7.-- Large ground-water users in the Coastal Plain area of Cecil County in 1950, 1960, 1970, and 1980, summarized by the Maryland Grid Coordinate System

\begin{tabular}{|c|c|c|c|c|c|}
\hline Year & Grid block & User & $\begin{array}{l}\text { Pumpage } \\
\text { (Mgal/d) }\end{array}$ & Aquifer & \\
\hline 1950 & $\begin{array}{ll}\text { N610 } & \text { E1130 } \\
\text { N640 } & \text { E1110 }\end{array}$ & $\begin{array}{l}\text { Chesapeake City } \\
\text { Thiokol Chemical Company }\end{array}$ & $\begin{array}{r}0.12 \\
.02\end{array}$ & $\begin{array}{l}\text { Potomac } \\
\text { Potomac }\end{array}$ & $\begin{array}{l}\text { Group } \\
\text { Group }\end{array}$ \\
\hline 1960 & $\begin{array}{ll}\text { N610 } & \text { E1130 } \\
\text { N640 } & \text { E1110 } \\
\text { N640 } & \text { E1130 }\end{array}$ & $\begin{array}{l}\text { Chesapeake City } \\
\text { Thiokol Chemical Company } \\
\text { Holly Hall Terrace Utility Corporation }\end{array}$ & $\begin{array}{r}0.14 \\
.02 \\
.03\end{array}$ & $\begin{array}{l}\text { Potomac } \\
\text { Potomac } \\
\text { Potomac }\end{array}$ & $\begin{array}{l}\text { Group } \\
\text { Group } \\
\text { Group }\end{array}$ \\
\hline 1970 & $\begin{array}{ll}\text { N570 } & \text { E1120 } \\
\text { N610 } & \text { E1130 } \\
\text { N620 } & \text { E1110 } \\
\text { N640 } & \text { E1110 } \\
\text { N640 } & \text { E1130 } \\
\text { N650 } & \text { E1120 }\end{array}$ & $\begin{array}{l}\text { Cecilton, Town of } \\
\text { Chesapeake City } \\
\text { Pine Hills Subdivision } \\
\text { Thiokol Chemical Company } \\
\text { Holly Hall Terrace Utility Corporation } \\
\text { Pirelli Cable Corporation }\end{array}$ & $\begin{array}{r}0.03 \\
.15 \\
.01 \\
.04 \\
.11 \\
.04\end{array}$ & $\begin{array}{l}\text { Magothy } \\
\text { Potomac } \\
\text { Potomac } \\
\text { Potomac } \\
\text { Potomac } \\
\text { Potomac }\end{array}$ & $\begin{array}{l}\text { Group } \\
\text { Group } \\
\text { Group } \\
\text { Group } \\
\text { Group }\end{array}$ \\
\hline 1980 & $\begin{array}{ll}\text { N570 } & \text { E1120 } \\
\text { N580 } & \text { E1090 } \\
\text { N590 } & \text { E1090 } \\
\text { N600 } & \text { E1080 } \\
\text { N610 } & \text { E1130 } \\
\text { N620 } & \text { E1070 } \\
\text { N620 } & \text { E1110 } \\
\text { N640 } & \text { E1110 } \\
\text { N640 } & \text { E1130 } \\
\text { N650 } & \text { E1100 } \\
\text { N650 } & \text { E1120 } \\
\text { N660 } & \text { E1130 }\end{array}$ & $\begin{array}{l}\text { Cecilton, Town of } \\
\text { Crystal Beach } \\
\text { Buttonwood Beach } \\
\text { Elk Neck State Park } \\
\text { Chesapeake City } \\
\text { Carpenters Point water system } \\
\text { Pine Hills Subdivision } \\
\text { Thiokol Chemical Company } \\
\text { Elkton: Holly Hall water system } \\
\text { Town and Country Mobile Home Park } \\
\text { Pirelli Cable Corporation } \\
\text { Meadowview Utilities, Incorporated }\end{array}$ & $\begin{array}{l}0.03 \\
.02 \\
.03 \\
.02 \\
.17 \\
.01 \\
.02 \\
.02 \\
.21 \\
.03 \\
.04 \\
.11\end{array}$ & $\begin{array}{l}\text { Magothy } \\
\text { Potomac } \\
\text { Potomac } \\
\text { Potomac } \\
\text { Potomac } \\
\text { Potomac } \\
\text { Potomac } \\
\text { Potomac } \\
\text { Potomac } \\
\text { Potomac } \\
\text { Potomac } \\
\text { Potomac }\end{array}$ & $\begin{array}{l}\text { Group } \\
\text { Group } \\
\text { Group } \\
\text { Group } \\
\text { Group } \\
\text { Group } \\
\text { Group } \\
\text { Group } \\
\text { Group } \\
\text { Group } \\
\text { Group }\end{array}$ \\
\hline
\end{tabular}




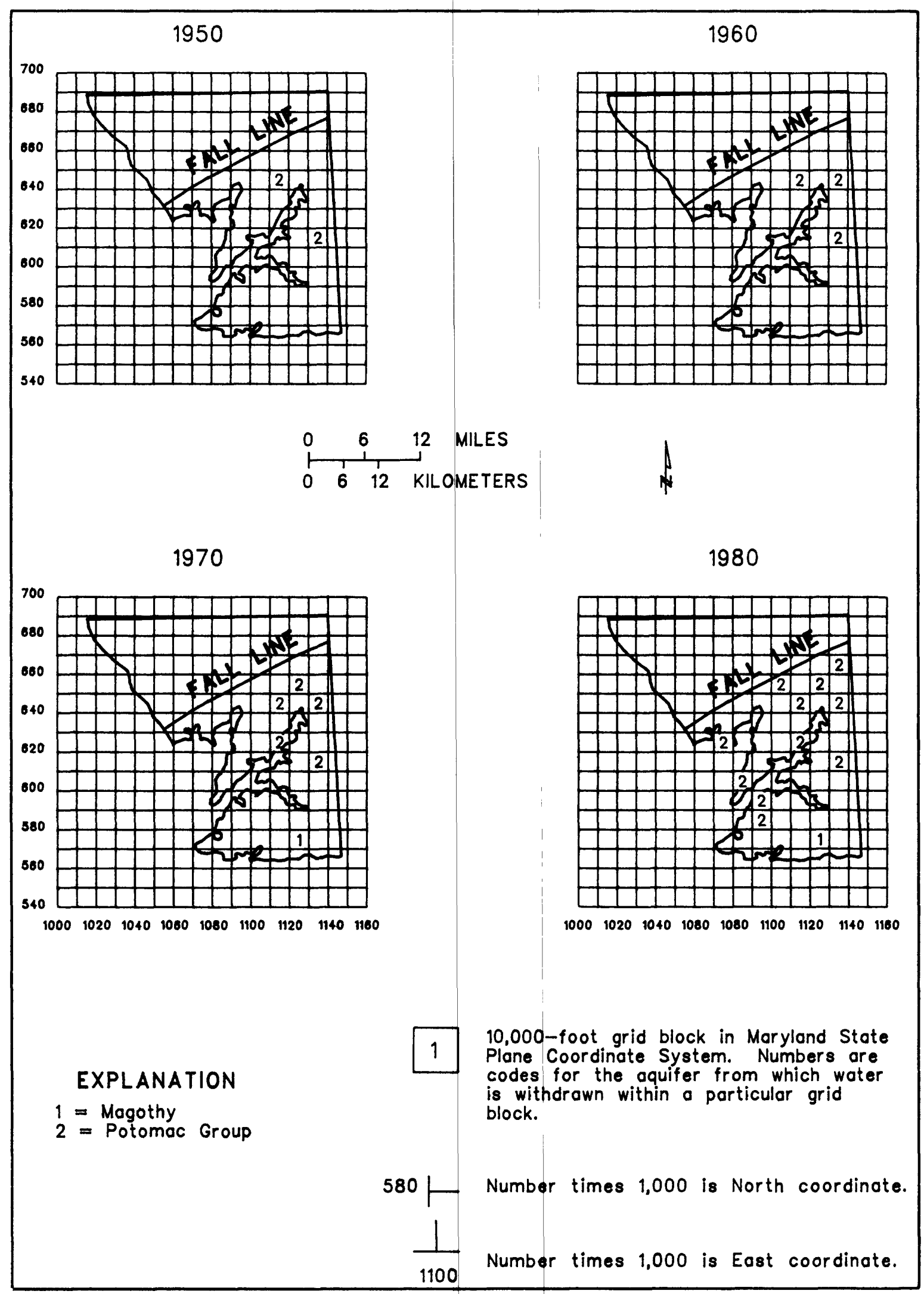

Figure 34.--Locations of large ground-water withdrawals by aquifers in the Coastal Plain area of Cecil County for 1950, 1960, 1970, and 1980. 


\section{CHARLES COUNTY}

Ground-water use in Charles County from 1950 through 1980 is shown in figure 35 . In 1950, the amount of ground water withdrawn was approximately 2.3 $\mathrm{Mgal} / \mathrm{d}$ compared to withdrawals of nearly $9.4 \mathrm{Mgal} / \mathrm{d}$ in 1980. This represents an increase of 292 percent for the three decades.

Since 1950, water use in the county increased in all categories. The greatest amount of water withdrawn was for domestic use, increasing from about $1.0 \mathrm{Mgal} / \mathrm{d}$ in 1950 to $3.7 \mathrm{Mgal} / \mathrm{d}$ in 1980 . Withdrawals by water suppliers increased from about $0.2 \mathrm{Mgal} / \mathrm{d}$ in 1950 to over $3.0 \mathrm{Mgal} / \mathrm{d}$ in 1980 . The greatest magnitude of these withdrawals occurred from the mid-1960's through 1980. Industrial/commercial pumpage showed a similar trend during the same period, increasing from less than $0.01 \mathrm{Mgal} / \mathrm{d}$ in 1950 to nearly $1.4 \mathrm{Mgal} / \mathrm{d}$ in 1980; water withdrawn for military use increased from about $1.0 \mathrm{Mgal} / \mathrm{d}$ in 1950 to nearly $2.2 \mathrm{Mgal} / \mathrm{d}$ in 1970 , gradually declining to about $1.0 \mathrm{Mgal} / \mathrm{d}$ again in 1980 . See appendix for ground-water withdrawal data for each large user: User's name, appropriation permit number, source aquifer, location on the Maryland Grid Coordinate System, average daily pumpage, and year pumping began

The percentages of total amount of ground water withdrawn for domestic, military, water supplier, and industrial/commercial uses for 1950,1960, 1970, and 1980 are shown in figure 36 . In 1950, domestic and military usage comprised 90 percent of the total pumpage, with only a small percentage each for water supplier and industrial/commercial uses. By 1960, the trend in water use had started to change. There were decreases in the percentage of water pumped for domestic and military uses and a significant increase in water withdrawn by water suppliers. A small increase in industrial/commercial use also was indicated. This trend continued through 1980 . However, the percentage of water withdrawn for domestic use remained relatively the same in 1960, 1970, and 1980.

\section{Major Aquifers}

Many domestic withdrawals in Charles County were from shallow wells (from about 15 to $80 \mathrm{ft}$ deep) tapping the surficial aquifer. Deeper aquifers including the Aquia, Magothy, Patapsco, and Patuxent were more widely used by large users. Large user withdrawals by aquifer from 1950 through 1980 are shown in figure 37. The Aquia aquifer was not used by large users until about 1970. Although there was an initial increase in its use, since about 1972 through 1980, withdrawals remained between $0.05 \mathrm{Mgal} / \mathrm{d}$ and $0.09 \mathrm{Mgal} / \mathrm{d}$. The use of the Magothy aquifer by large users began in 1962 and grew considerably from approximately $0.01 \mathrm{Mgal} / \mathrm{d}$ in 1960 to about $2.2 \mathrm{Mgal} / \mathrm{d}$ in 1980 . Withdrawals from the Patapsco aquifer were about $0.6 \mathrm{Mgal} / \mathrm{d}$ in 1950 and gradually increased to about $1.8 \mathrm{Mgal} / \mathrm{d}$ in 1969 . From 1970 to 1980 , greater amounts of water were withdrawn from the Patapsco aquifer with nearly $2.4 \mathrm{Mgal} / \mathrm{d}$ pumped in 1980. The Patuxent aquifer provided about $0.3 \mathrm{Mgal} / \mathrm{d}$ in 1950 . Withdrawals from this aquifer increased through 1971 to nearly $1.0 \mathrm{Mgal} / \mathrm{d}$, then declined to about half that amount $(0.5 \mathrm{Mgal} / \mathrm{d})$ in 1973 , and remained relatively constant through 1980 .

\section{Locations of Large Ground-Water Withdrawals}

The locations of withdrawals by large users in Charles County for 1950, 1960, 1970, and 1980 are shown in figure 38 . Table 8 presents water-use data for the large users located within particular grid blocks for the year indicated on the map. For the years shown, the areas of greatest withdrawals were located in the northwestern, central, and north-central part (Waldorf area) of the county.

The withdrawals from individual aquifers supplying the large users in Charles County (described in table 8 and fig. 38) are shown in figure 39. Withdrawals from the Aquia aquifer for 1980 were limited to a single location in the central part of the county. Withdrawals from the Magothy aquifer began in 1960 in the northcentral area. Its use by large users grew substantially from that time, although its areal distribution remained the same.

The Patuxent and Patapsco were the principal aquifers supplying large users in 1950 . Their distribution of use centered mostly in the northwestern part of the county, with only one site located in the central section. The pattern of use of the aquifers remained essentially the same through 1960 and 1970 . However, by 1980 , a noticeable increase in the number of withdrawal sites from the Patuxent and Patapsco aquifers was evident, especially in the north-central area of the county. 


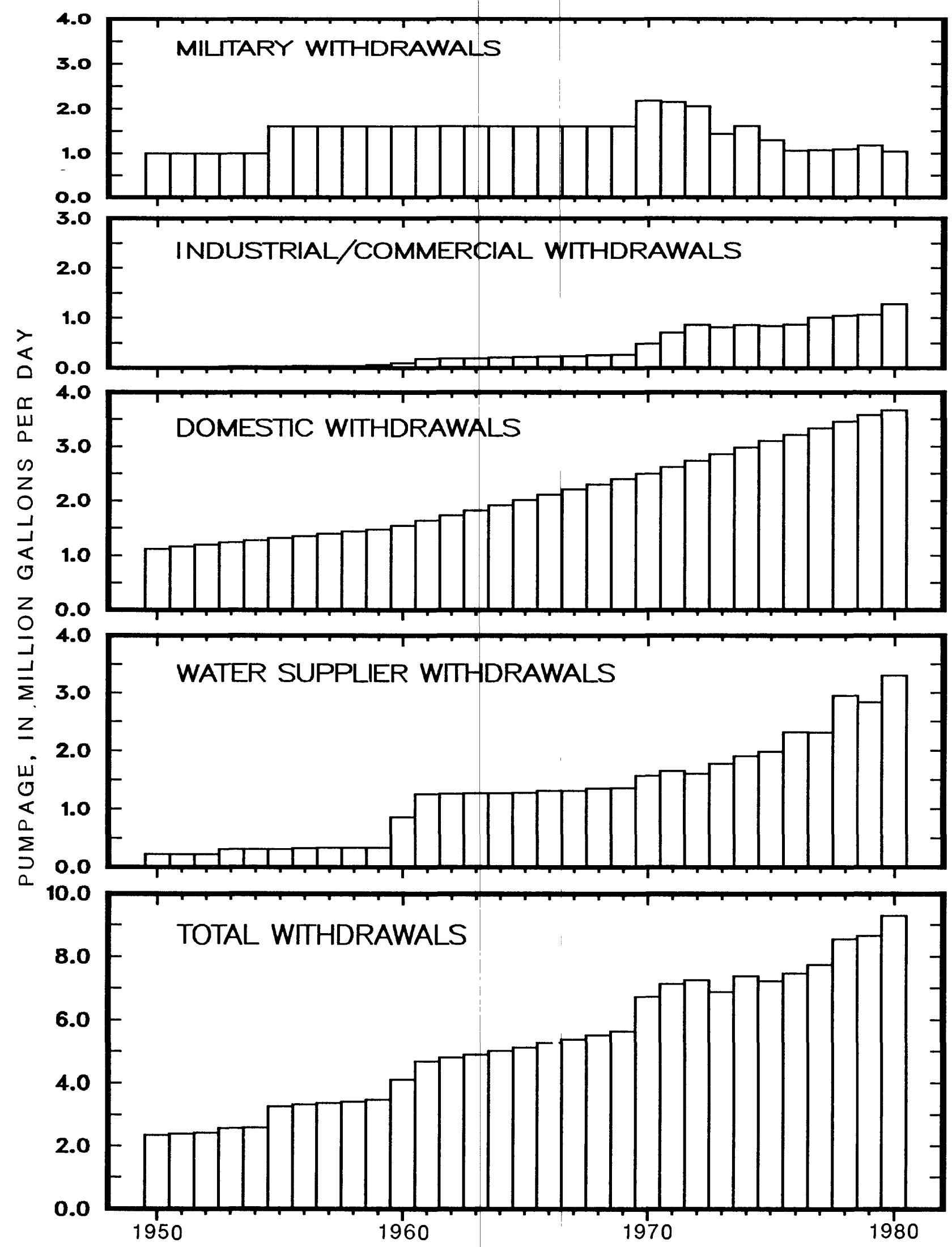

Figure 35.-- Ground-water withdrawals by use in Charles County from 1950 through 1980. 

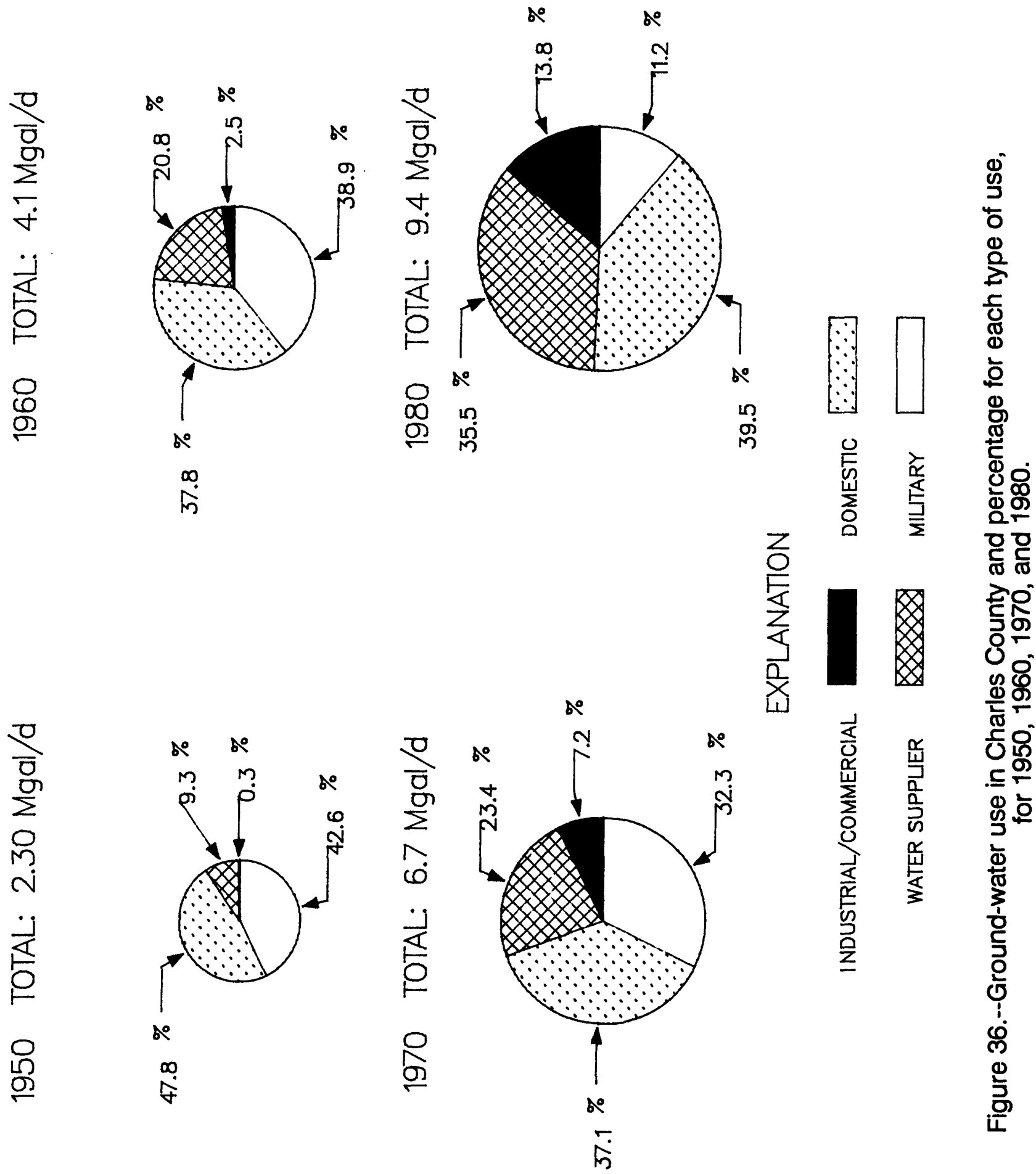


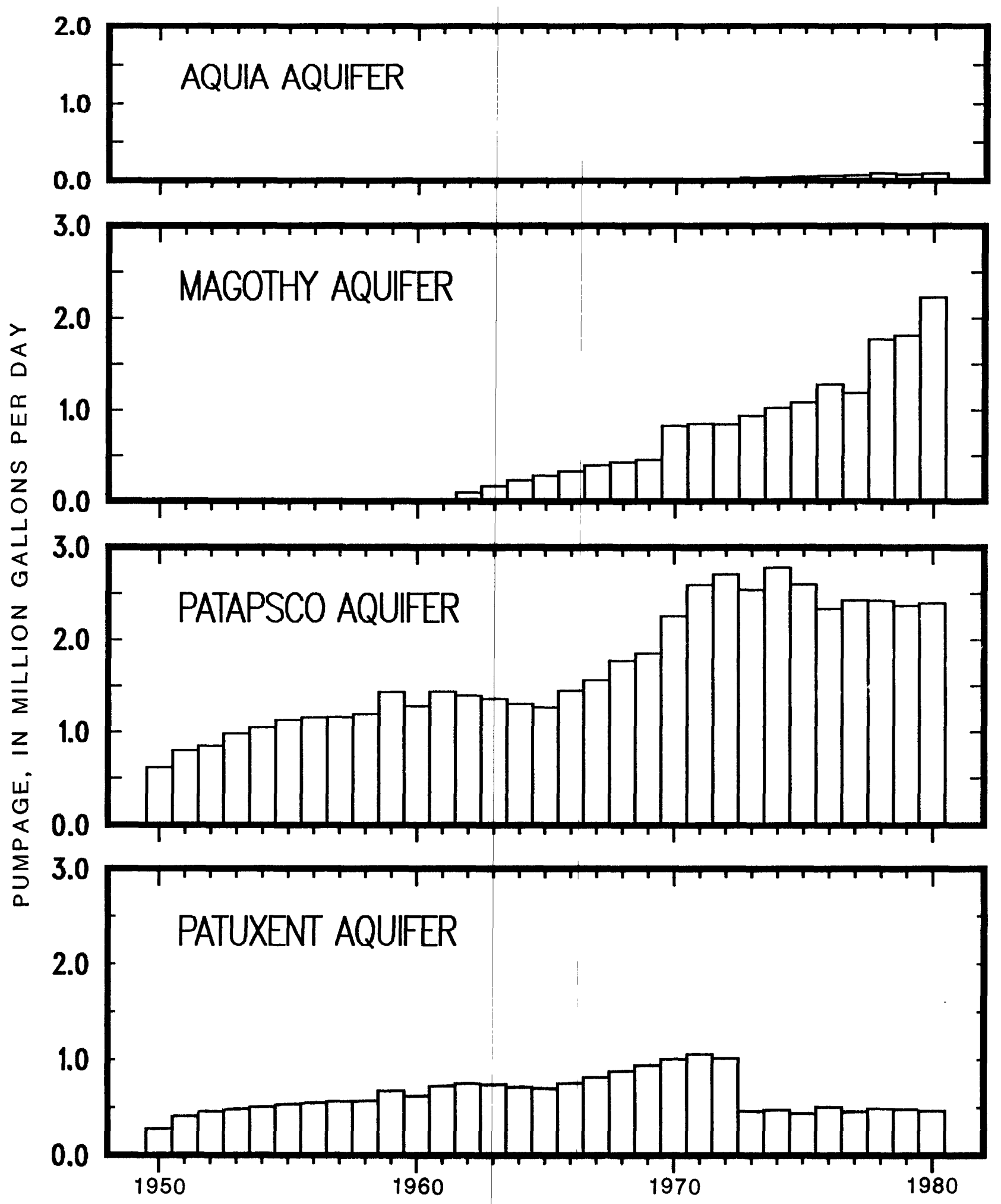

Figure 37.--Large ground-water withdrawals by aquifers in Charles County from 1950 through 1980. 


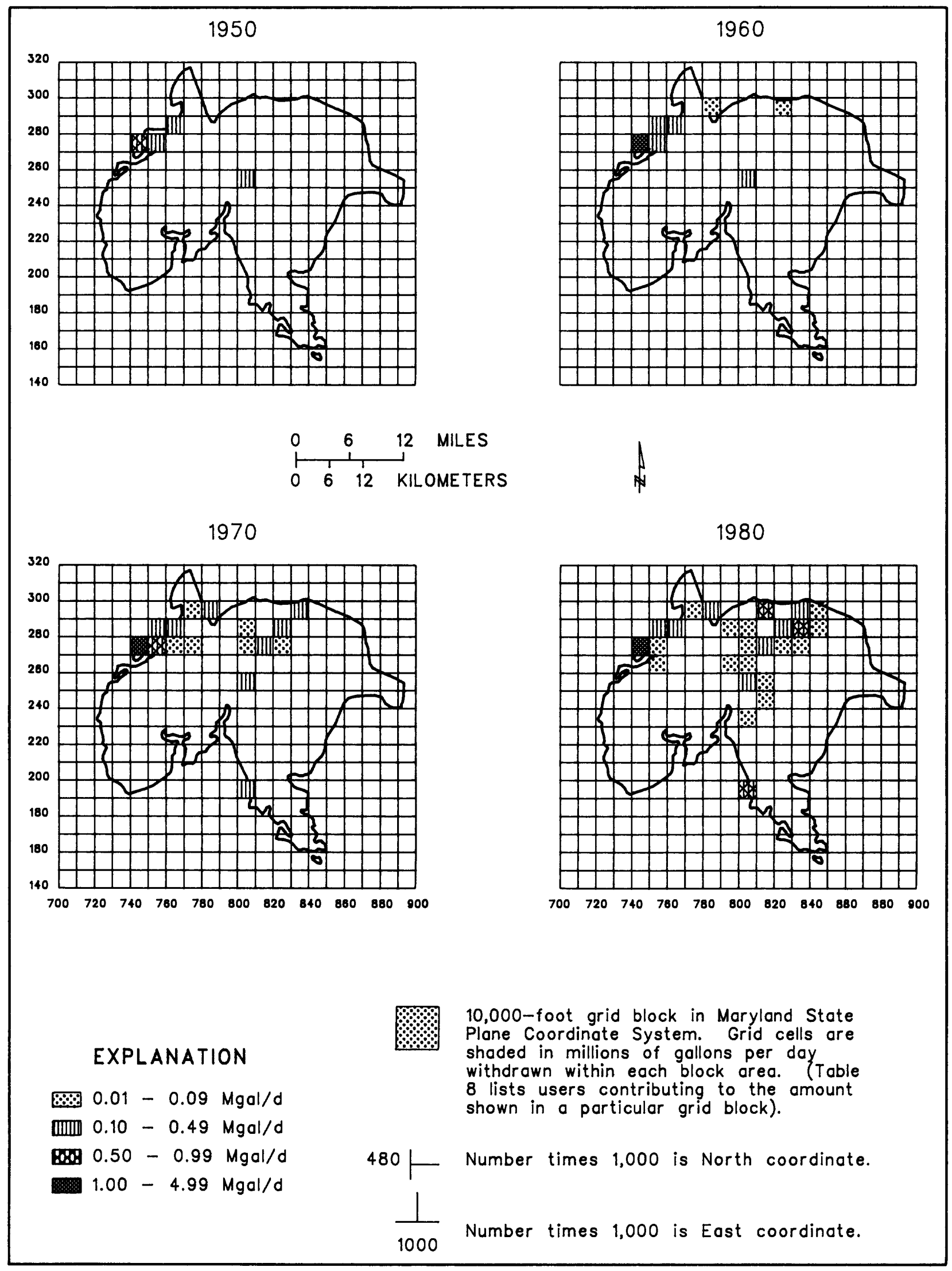

Figure 38.--Locations of large ground-water withdrawals in Charles County for 1950, 1960, 1970, and 1980. 
Table 8.--Large ground-water users in Charles County in 1950, 1960, 1970, and 1980, summarized by the Maryland Grid Coordinate System

\begin{tabular}{|c|c|c|c|c|c|}
\hline Year & Grid & block & User & $\begin{array}{l}\text { umpage } \\
\text { Mal/d) }\end{array}$ & Aquifer \\
\hline 1950 & $\begin{array}{l}\text { N250 } \\
\text { N270 } \\
\text { N270 } \\
\text { N280 }\end{array}$ & $\begin{array}{l}\text { E800 } \\
\text { E740 } \\
\text { E750 } \\
\text { E760 }\end{array}$ & $\begin{array}{l}\text { LaPlata, Town of } \\
\text { U.S. Naval Ordnance Station } \\
\text { do. } \\
\text { Potomac Heights Home Omers As\$ociation }\end{array}$ & $\begin{array}{r}0.10 \\
.52 \\
.22 \\
.10\end{array}$ & $\begin{array}{l}\text { Patapsco } \\
\text { Patapsco } \\
\text { Patuxent } \\
\text { Patuxent }\end{array}$ \\
\hline 1960 & $\begin{array}{l}\text { N250 } \\
\text { N270 } \\
\text { N270 } \\
\text { N280 } \\
\text { N280 } \\
\text { N290 } \\
\text { N290 }\end{array}$ & $\begin{array}{l}\text { E800 } \\
\text { E740 } \\
\text { E750 } \\
\text { E750 } \\
\text { E760 } \\
\text { E780 } \\
\text { E820 }\end{array}$ & $\begin{array}{l}\text { LaPlata, Town of } \\
\text { U.S. Naval Ordnance Station } \\
\text { do. } \\
\text { Woodland Village } \\
\text { Indian Head, Town of } \\
\text { Potomac Heights Home Omars Association } \\
\text { Charles Utilities Commission, Inc. } \\
\text { Stardust Motel }\end{array}$ & $\begin{array}{r}0.14 \\
1.00 \\
.44 \\
.02 \\
.11 \\
.10 \\
.04 \\
.01\end{array}$ & $\begin{array}{l}\text { Patapsco } \\
\text { Patapsco } \\
\text { Patuxent } \\
\text { Patuxent } \\
\text { Patapsco } \\
\text { Patuxent } \\
\text { Patuxent } \\
\text { Magothy }\end{array}$ \\
\hline 1970 & $\begin{array}{l}N 190 \\
N 250 \\
N 280 \\
N 270 \\
N 270 \\
N 270 \\
N 270 \\
N 270 \\
N 270 \\
N 270 \\
N 280 \\
N 280 \\
N 280 \\
N 290 \\
N 290 \\
\text { N290 } \\
\text { N290 }\end{array}$ & $\begin{array}{l}\text { E800 } \\
\text { E800 } \\
E 800 \\
\text { E740 } \\
\text { E750 } \\
\text { E760 } \\
\text { E770 } \\
\text { E800 } \\
\text { E810 } \\
\text { E820 } \\
\text { E750 } \\
\text { E760 } \\
\text { E820 } \\
\text { E770 } \\
\text { E780 } \\
\text { E830 }\end{array}$ & $\begin{array}{l}\text { PEPCO, Morgantown } \\
\text { LaPlata, Town of } \\
\text { Brookwood Utilities } \\
\text { U.S. Naval Ordnance Station } \\
\text { do. } \\
\text { Woodland Village } \\
\text { Lackey High School } \\
\text { Pomonkey Water Commission, Inc. } \\
\text { Oak Hill Estates } \\
\text { South well - Waldorf system, } \\
\quad \text { Charles County } \\
\text { White Plains Park } \\
\text { Indian Head, Town of } \\
\text { Potomac Heights Home Omers Association } \\
\text { St. Charles City - Waldorf system, } \\
\text { Charles County DFW } \\
\text { Potomac Utilities Corporation } \\
\text { Inman Utilities Company } \\
\text { Charles Utilities Commission, Inc. } \\
\text { North well - Waldorf system, } \\
\text { Charles County, DPW }\end{array}$ & $\begin{array}{r}0.27 \\
.17 \\
.03 \\
1.52 \\
.65 \\
.02 \\
.01 \\
.01 \\
.01 \\
.21 \\
.02 \\
.19 \\
.12 \\
.37 \\
.03 \\
.01 \\
.11 \\
.21\end{array}$ & $\begin{array}{l}\text { Patapsco } \\
\text { Patapsco } \\
\text { Magothy } \\
\text { Patapsco } \\
\text { Patuxent } \\
\text { Patuxent } \\
\text { Patapsco } \\
\text { Patuxent } \\
\text { Patapsco } \\
\text { Magothy } \\
\text { Patapsco } \\
\text { Patapsco } \\
\text { Patuxent } \\
\text { Magothy } \\
\text { Patapsco } \\
\text { Patapsco } \\
\text { Patuxent } \\
\text { Magothy }\end{array}$ \\
\hline 1980 & $\begin{array}{l}N 270 \\
N 270 \\
N 280 \\
N 280 \\
N 280 \\
N 280 \\
N 280 \\
N 280 \\
N 290 \\
N 290 \\
N 290 \\
N 290 \\
N 290\end{array}$ & $\begin{array}{l}\text { E820 } \\
\text { E830 } \\
\text { E750 } \\
\text { E760 } \\
\text { E790 } \\
\text { E820 } \\
\text { E830 } \\
\text { E840 } \\
\text { E770 } \\
\text { E780 } \\
\text { E810 } \\
\text { E830 } \\
\text { E840 }\end{array}$ & 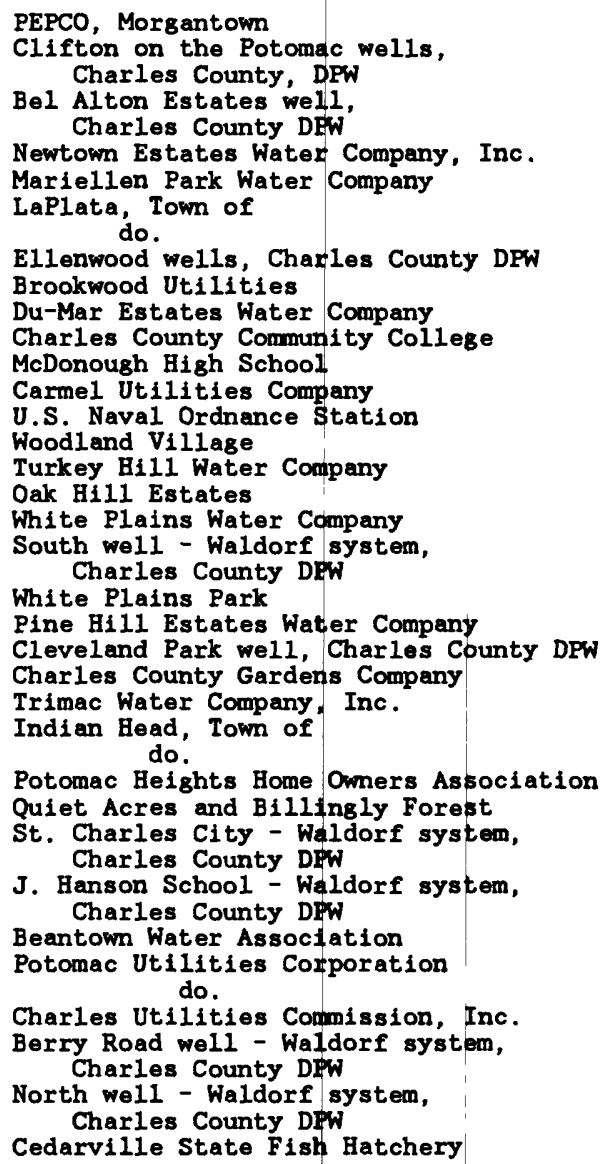 & $\begin{array}{l}0.76 \\
.04 \\
.01 \\
.02 \\
.02 \\
.01 \\
.28 \\
.02 \\
.04 \\
.01 \\
.01 \\
.01 \\
.02 \\
1.04 \\
.03 \\
.01 \\
.01 \\
.02 \\
.27 \\
.07 \\
.01 \\
.01 \\
.03 \\
.02 \\
.10 \\
.11 \\
.14 \\
.01 \\
.28 \\
.65 \\
.01 \\
.01 \\
.05 \\
.12 \\
.62 \\
.19 \\
.09\end{array}$ & $\begin{array}{l}\text { Patapsco } \\
\text { Aquia } \\
\text { Patapsco } \\
\text { Aquia } \\
\text { Aquia } \\
\text { Aquia } \\
\text { Patapsco } \\
\text { Patapsco } \\
\text { Magothy } \\
\text { Patuxent } \\
\text { Patapsco } \\
\text { Patapsco } \\
\text { Patapsco } \\
\text { Patapsco } \\
\text { Patuxent } \\
\text { Patapsco } \\
\text { Patapsco } \\
\text { Magothy } \\
\text { Magothy } \\
\text { Patapsco } \\
\text { Magothy } \\
\text { Magothy } \\
\text { Magothy } \\
\text { Patapsco } \\
\text { Patapsco } \\
\text { Patuxent } \\
\text { Patuxent } \\
\text { Patuxent } \\
\text { Magothy } \\
\text { Magothy } \\
\text { Magothy } \\
\text { Patapsco } \\
\text { Patuxent } \\
\text { Patuxent } \\
\text { Magothy } \\
\text { Magothy } \\
\text { Magothy }\end{array}$ \\
\hline
\end{tabular}




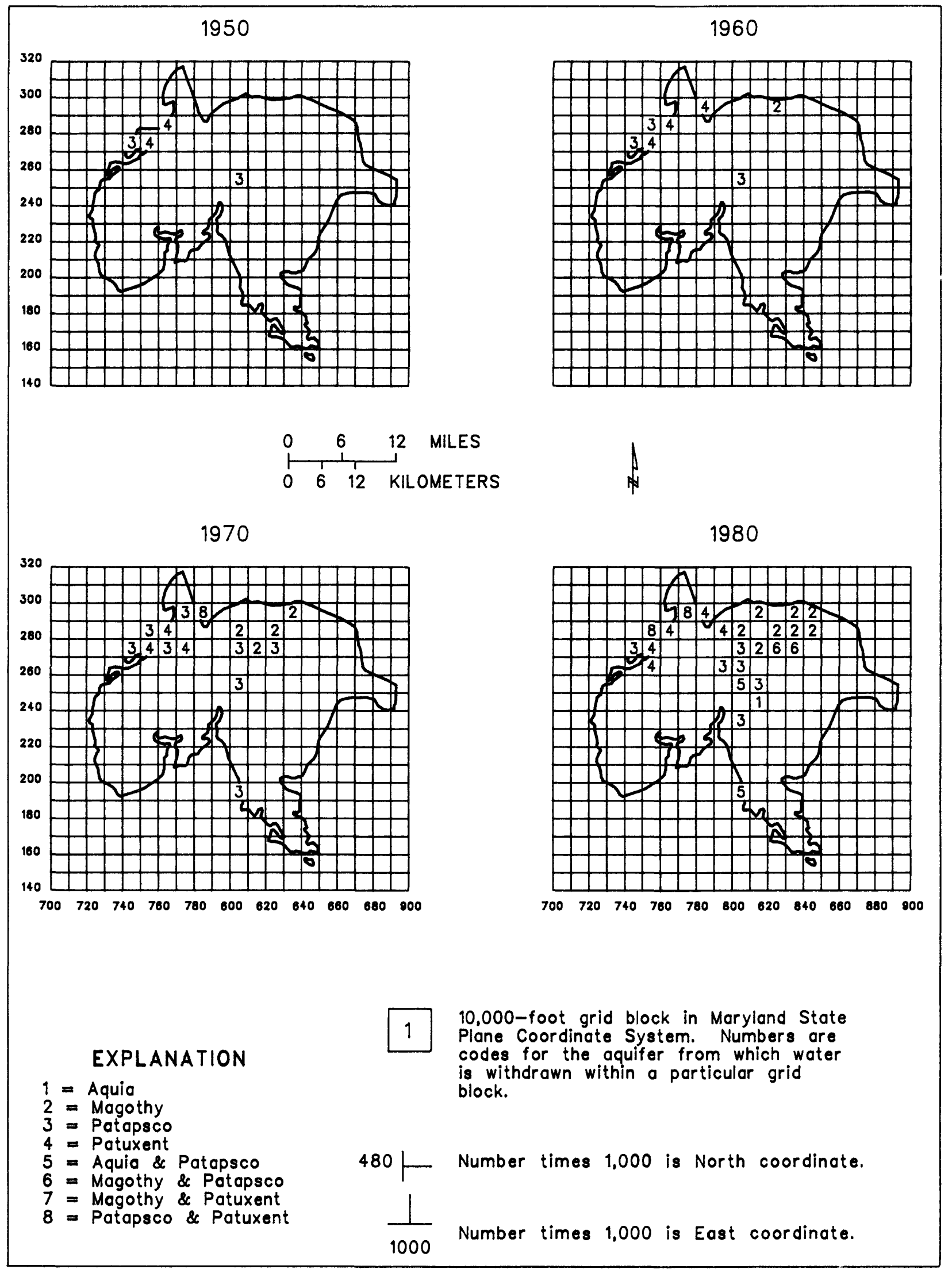

Figure 39.--Locations of large ground-water withdrawals by aquifers in Charles County for 1950, 1960, 1970, and 1980. 


\section{DORCHESTER COUNTY}

Ground-water use in Dorchester County from 1950 through 1980 is shown in figure 40 . In 1950, the amount of ground water withdrawn was approximately 4.2 $\mathrm{Mgal} / \mathrm{d}$ compared to withdrawals of nearly $9.2 \mathrm{Mgal} / \mathrm{d}$ in 1980. This represents an increase of 119 percent for the three decades.

The largest use of ground water in the county was by water suppliers who withdrew nearly $3.0 \mathrm{Mgal} / \mathrm{d}$ in 1950 , increasing to about $3.4 \mathrm{Mgal} / \mathrm{d}$ in 1980 . Irrigation use increased considerably from about $0.6 \mathrm{Mgal} / \mathrm{d}$ in 1960 to about $3.4 \mathrm{Mgal} / \mathrm{d}$ in 1980 . Irrigation was an important water use in the county since about the early 1960's. Although there were no precise measurements of the amounts of water withdrawn by individual irrigators, methods of collecting and reporting these data have improved since the 1960's. The most reliable data were for 1970 to 1980 . See appendix for ground-water withdrawal data for each large user: User's name, appropriation permit number, source aquifer, location on the Maryland Grid Coordinate System, average daily pumpage, and year pumping began.

The percentages of the total amount of ground water withdrawn for domestic, water supplier, industrial/commercial, and irrigation uses for 1950, 1960, 1970 , and 1980 are shown in figure 41 . It is evident that water suppliers comprised a significant portion of the total pumpage for 1950, 1960, and 1970 . The figure also illustrates that the percentage of water used for irrigation has increased considerably, from 9 percent in 1960 to 37 percent in 1980 .

\section{Major Aquifers}

The earliest ground-water pumpage in Dorchester County probably came from the surficial (Quaternary) aquifer. Although these shallow sands continued to supply much of the low-yield water needs, chiefly for domestic use, a few large users were able to withdraw sufficient quantities of water. As the demand for water increased, the use of deeper aquifers, including the lower Chesapeake, Piney Point, Magothy, and Patapsco aquifers, increased. Large-user withdrawals by aquifer from 1950 through 1980 are shown in figure 42.

The Piney Point aquifer served as the major source of water for the 30-year period. In 1950, approximately 2.7 Mgal/d was withdrawn from the aquifer by large users. Pumpage increased to nearly $4.5 \mathrm{Mgal} / \mathrm{d}$ in 1956 , but then began a declining trend over the next 20 years. By 1980 , withdrawals had dropped to just more than 1.8 $\mathrm{Mgal} / \mathrm{d}$. For most of the 30 years, withdrawals from the other aquifers remained less than $0.9 \mathrm{Mgal} / \mathrm{d}$ (withdrawals from the Patapsco aquifer reached about $1.0 \mathrm{Mgal} / \mathrm{d}$ in 1980).

\section{Locations of Large Ground-Water Withdrawals}

The locations of withdrawals by large users in Dorchester County for 1950,1960,1970, and 1980 are shown in figure 43. Table 9 presents water- use data for the large users located within particular grid blocks for the year indicated on the map. In 1950, the areas of heaviest pumpage were located mostly along the northern border of the county. Distribution patterns remained relatively the same for the other years shown, with only a few sites added by 1980 .

The locations of withdrawals from individual aquifers supplying the large users in Dorchester County (described in table 9 and fig. 43) are shown in figure 44. The maps indicate little change in development or use of the aquifers in the county, with distribution remaining centered along the northern and eastern borders. 


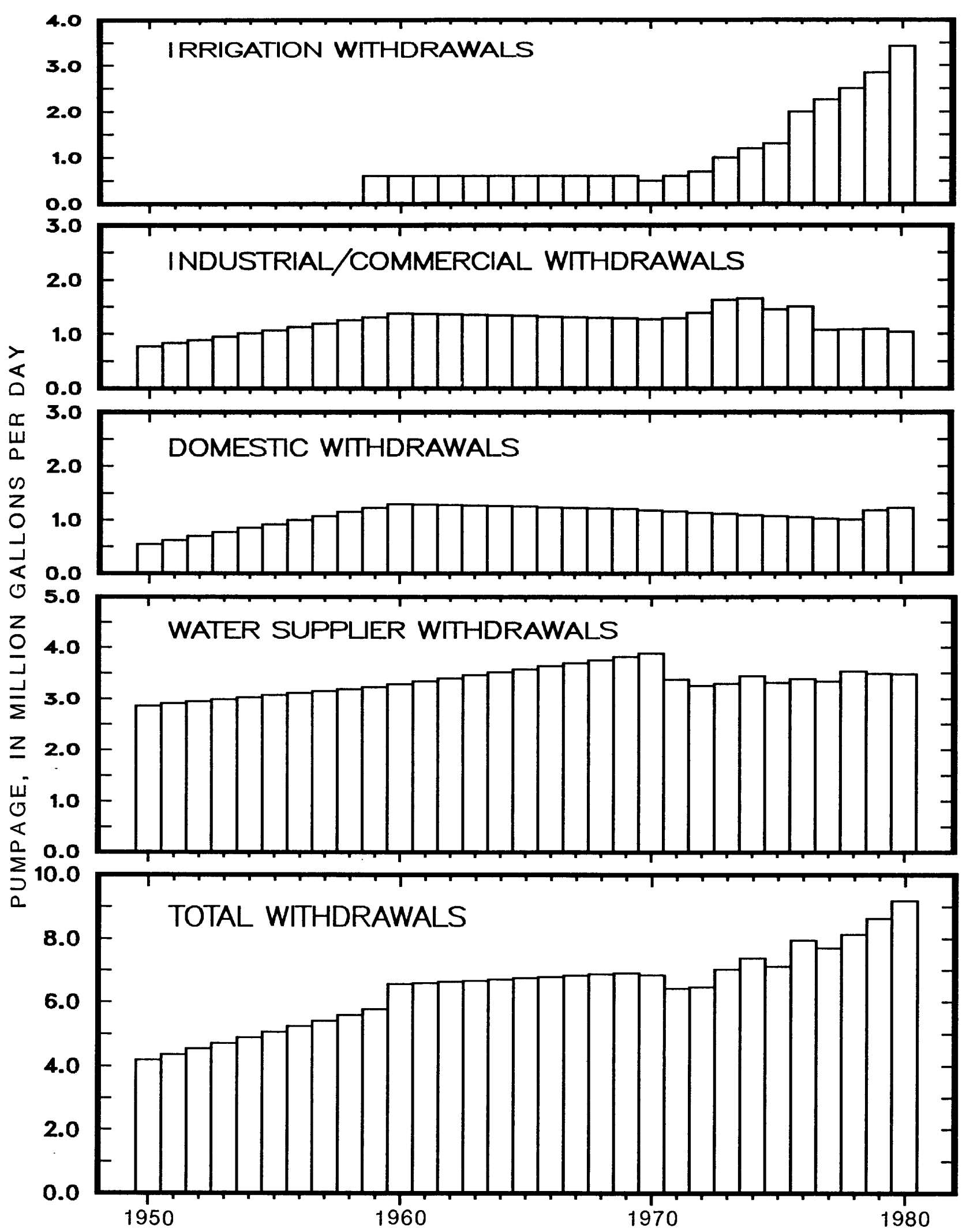

Figure 40.--Ground-water withdrawals by use in Dorchester County from 1950 through 1980. 


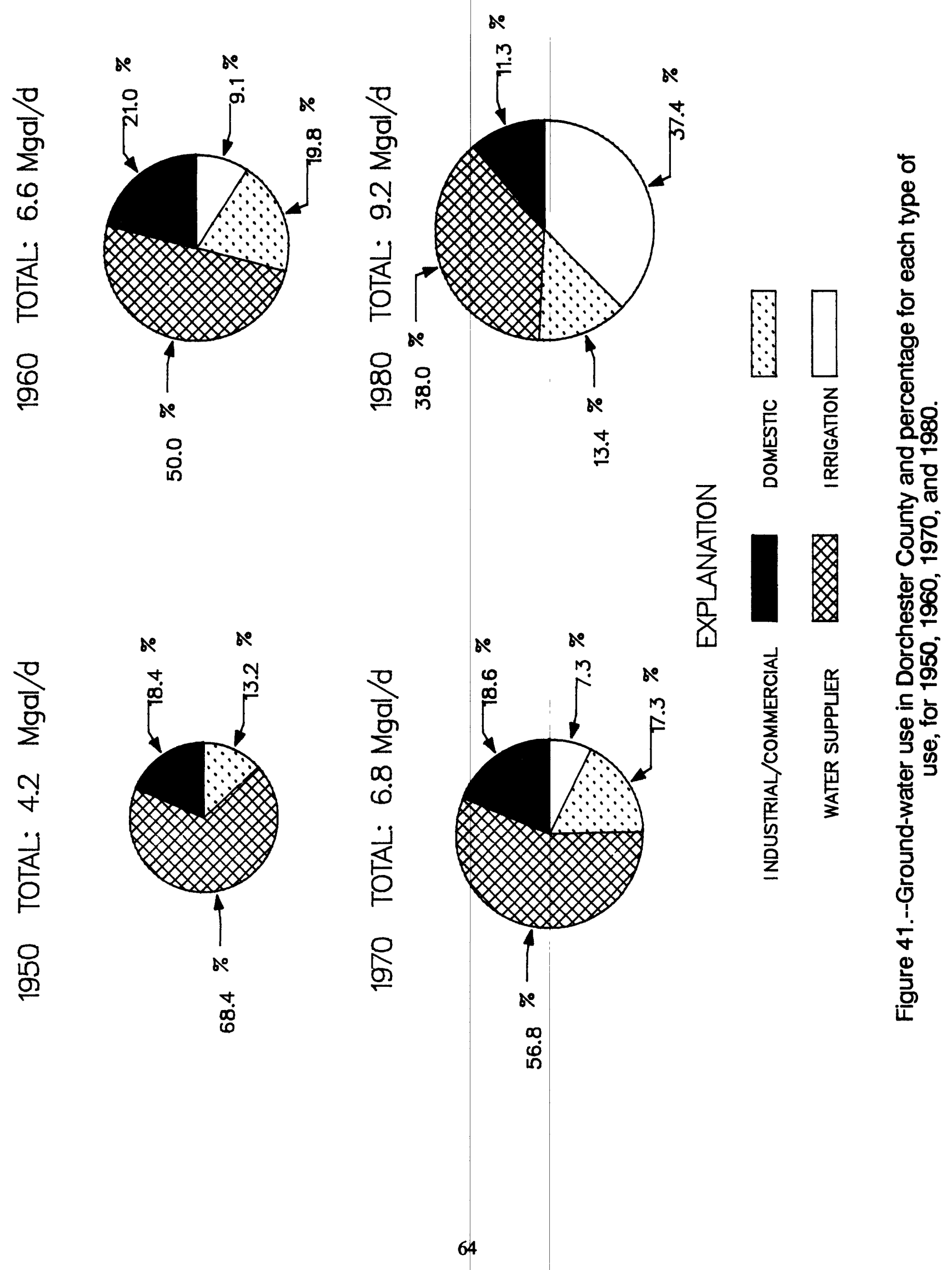




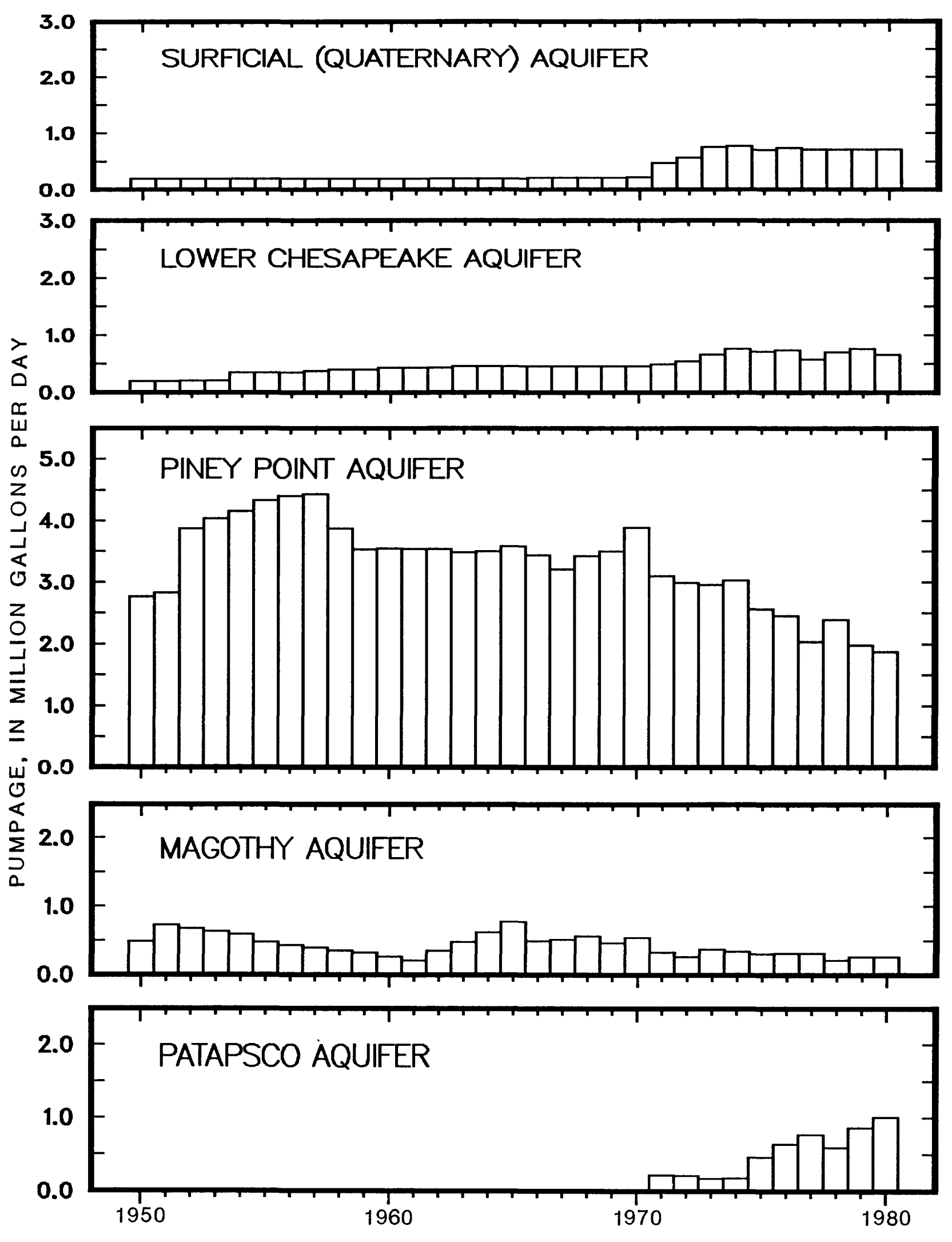

Figure 42.--Large ground-water withdrawals by aquifers in Dorchester County from 1950 through 1980. 

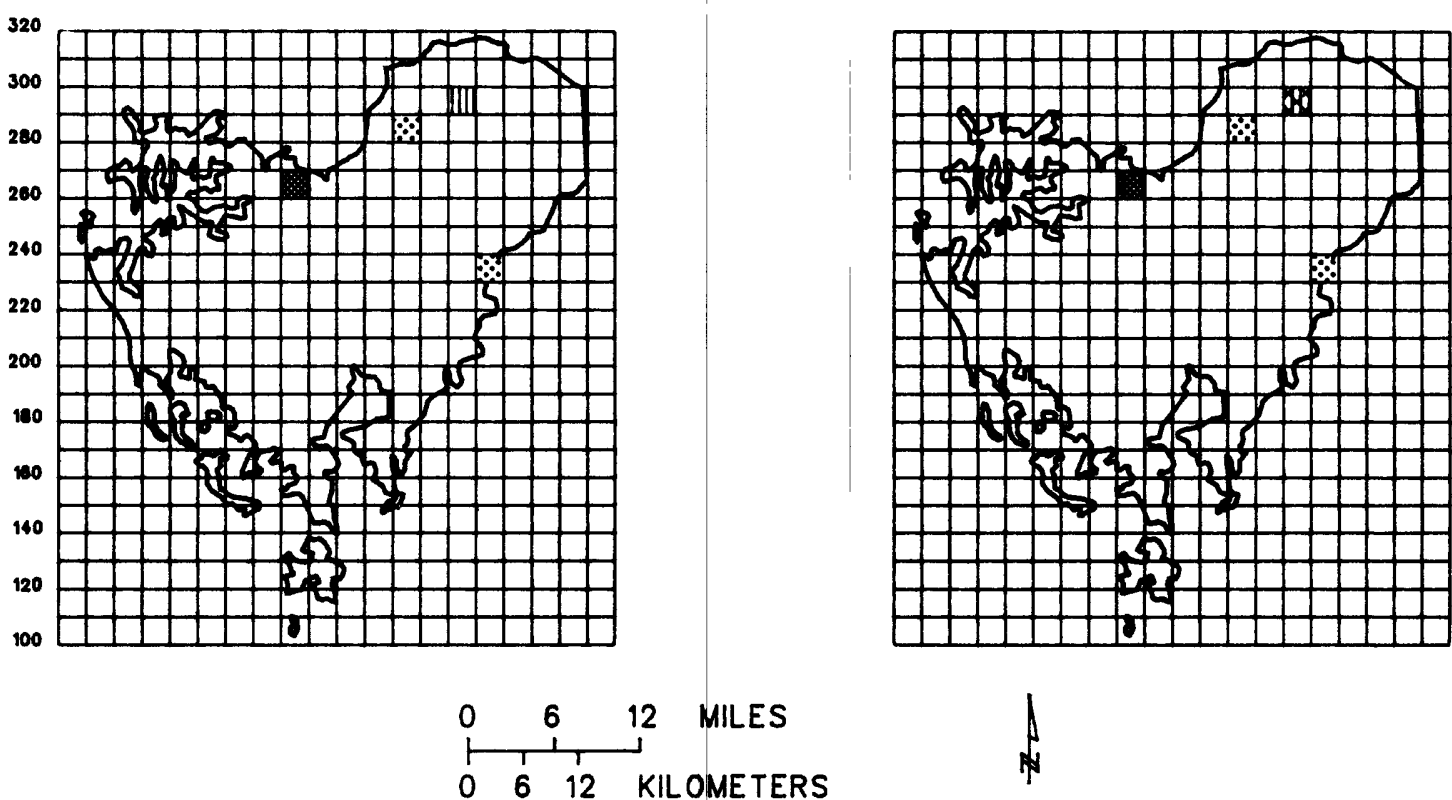

1970

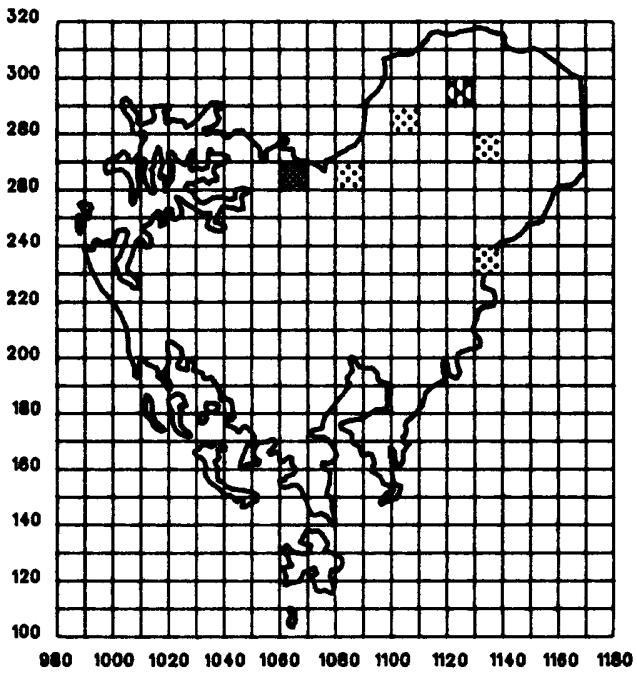

\section{EXPLANATION}

$0.01-0.09 \mathrm{Mgal} / \mathrm{d}$

而 $0.10-0.49 \mathrm{Mgal} / \mathrm{d}$

$0.50-0.99 \mathrm{Mgal} / \mathrm{d}$

$1.00-4.99 \mathrm{Mgal} / \mathrm{d}$
1980

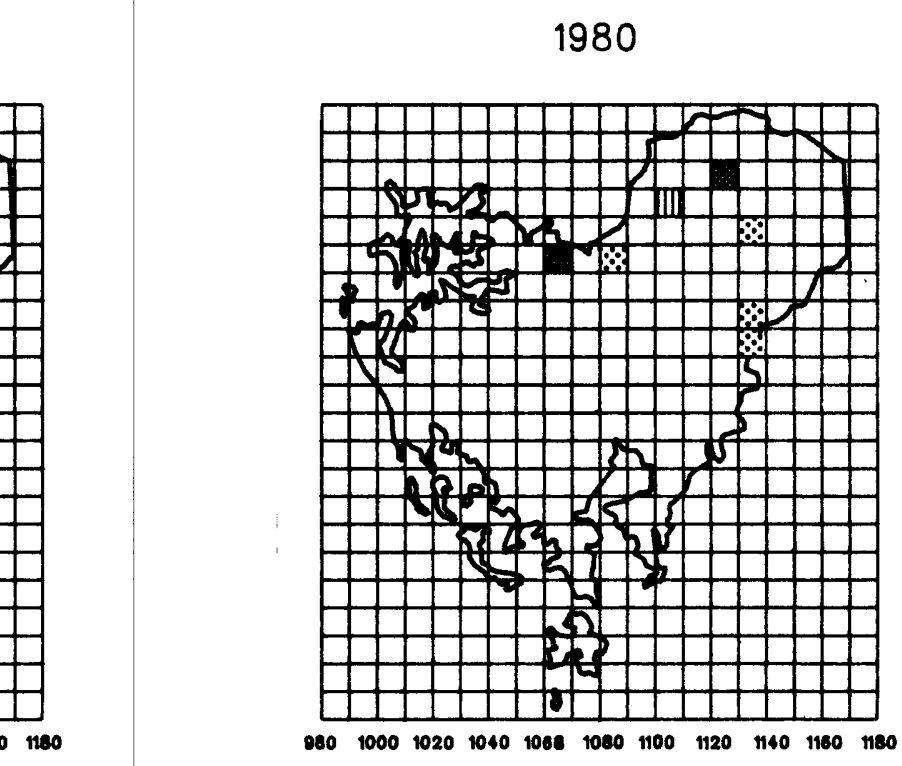

$980100010201040108010801100 \quad 1120 \quad 1140 \quad 1180 \quad$ nso

10,000-foot grid block in Maryland State Plane Coordinate System. Grid cells are shaded in millions of gallons per day withdrawn within each block area. (Table 9 lists users contributing to the amount shown in a particular grid block).

Number times 1,000 is North coordinate.

Number times 1,000 is East coordinate.

Figure 43.--Locations of large ground-water withdrawals in Dorchester County for 1950 , 1960, 1970, and 1980. 
Table 9.--Large ground-water users in Dorchester County in 1950, 1960, 1970, and 1980, sumarized by the Maryland Grid Coordinate System

\begin{tabular}{|c|c|c|c|c|}
\hline Year & Grid block & User & $\begin{array}{l}\text { Pumpage } \\
\text { (Msa1/d) }\end{array}$ & Aquifer \\
\hline 1950 & $\begin{array}{ll}\text { N230 } & \text { E1130 } \\
\text { N260 } & \text { E1060 } \\
& \\
\text { N280 } & E 1100 \\
\text { N290 } & E 1120\end{array}$ & $\begin{array}{l}\text { Vienna, Tom of } \\
\text { East Coast Cold Storage } \\
\text { Cambridge, City of } \\
\text { do. } \\
\text { Crystal Ice \& Cold Storage } \\
\text { do. } \\
\text { Secretary, Town of } \\
\text { East New Market, Town of } \\
\text { Burlock, Town of } \\
\text { Bloch \& Gugsenhelmer, Inc. }\end{array}$ & $\begin{array}{r}0.05 \\
.22 \\
2.40 \\
.41 \\
.08 \\
.06 \\
.04 \\
.03 \\
.12 \\
.18\end{array}$ & $\begin{array}{l}\text { Calvert } \\
\text { Piney Point } \\
\text { Piney Point } \\
\text { Magothy } \\
\text { Piney Point } \\
\text { Magothy } \\
\text { Piney Point } \\
\text { Calvert } \\
\text { Frederica } \\
\text { Quaternary }\end{array}$ \\
\hline 1860 & $\begin{array}{l}\text { N280 E1100 } \\
\text { N290 E1120 }\end{array}$ & $\begin{array}{l}\text { Vienna, Town of } \\
\text { Banover Brands } \\
\text { East Coast Cold Storage } \\
\text { Cambridge, City of } \\
\text { do. } \\
\text { Bumble Bee Corporation } \\
\text { Crystal Ice \& Cold Storage } \\
\text { do. } \\
\text { Secretary, Town of } \\
\text { East New Market, Town of } \\
\text { Burlock, Town of } \\
\text { ACME Markets, Inc. } \\
\text { Bloch \& Guggenheimer, Inc. } \\
\text { Burlock Plckling Company }\end{array}$ & $\begin{array}{r}0.05 \\
.32 \\
.22 \\
2.50 \\
.18 \\
.44 \\
.08 \\
.08 \\
.04 \\
.03 \\
.13 \\
.22 \\
.19 \\
.05\end{array}$ & $\begin{array}{l}\text { Calvert } \\
\text { Piney Point } \\
\text { Piney Point } \\
\text { Piney Point } \\
\text { Magothy } \\
\text { Piney Point } \\
\text { Piney Point } \\
\text { Magothy } \\
\text { Piney Point } \\
\text { Calvert } \\
\text { Frederica } \\
\text { Frederica } \\
\text { Quaternary } \\
\text { Frederica }\end{array}$ \\
\hline 1970 & $\begin{array}{ll}\text { N260 } & \text { E1080 } \\
\text { N270 } & \text { E1130 } \\
\text { N280 } & \text { E1100 } \\
\text { N290 } & \text { E1120 }\end{array}$ & $\begin{array}{l}\text { Vienna, Town of } \\
\text { Banover Brands } \\
\text { East Coast Cold Storage } \\
\text { Cambridge, C1ty of } \\
\text { Bumble Bee Corporation } \\
\text { Crystal Ice \& Cold Storage } \\
\text { Bonnle Brook, Dorchester County } \\
\text { Dececco Corporation } \\
\text { Secretary, Tom of } \\
\text { East New Market, Town of } \\
\text { Burlock, Town of } \\
\text { ACME Markets, Inc. } \\
\text { Bloch \& Guggenhelmer, Inc. } \\
\text { Burlock Plckling Company }\end{array}$ & $\begin{array}{r}0.04 \\
.25 \\
.20 \\
3.16 \\
.47 \\
.14 \\
.08 \\
.08 \\
.02 \\
.02 \\
.03 \\
.04 \\
.13 \\
.25 \\
.19 \\
.05\end{array}$ & $\begin{array}{l}\text { Calvert } \\
\text { Piney Point } \\
\text { Piney Point } \\
\text { Piney Point } \\
\text { Magothy } \\
\text { Piney Point } \\
\text { Piney Point } \\
\text { Magothy } \\
\text { Piney Point } \\
\text { Quaternary } \\
\text { Piney Point } \\
\text { Calvert } \\
\text { Frederica } \\
\text { Frederica } \\
\text { Quaternary } \\
\text { Frederica }\end{array}$ \\
\hline 1980 & $\begin{array}{ll}\text { N260 } & \text { E1080 } \\
\text { N270 } & \text { E1130 } \\
\text { N280 } & \text { E1100 } \\
& \\
\text { N290 } & \text { E1120 }\end{array}$ & $\begin{array}{l}\text { Vienna, Town of } \\
\text { Delmarva Power \& Light Company } \\
\text { East Coast Cold Storage } \\
\text { Cambridge, City of } \\
\text { do. } \\
\text { do. } \\
\text { Bonnie Brook, Dorchester County } \\
\text { Dececco Corporation } \\
\text { Secretary, Town of } \\
\text { East New Market, Town of } \\
\text { Burlock, Town of } \\
\text { Country Pride Foods, Inc. } \\
\text { ACME Markets, Inc. } \\
\text { Bloch \& Gugsenhimer, Inc. }\end{array}$ & $\begin{array}{r}0.07 \\
.03 \\
.05 \\
1.00 \\
1.73 \\
.26 \\
.02 \\
.03 \\
.08 \\
.03 \\
.29 \\
.46 \\
.26 \\
.19\end{array}$ & $\begin{array}{l}\text { Calvert } \\
\text { Quaternary } \\
\text { Piney Polnt } \\
\text { Patapsco } \\
\text { Piney Point } \\
\text { Magothy } \\
\text { Piney Point } \\
\text { Quaternary } \\
\text { Piney Point } \\
\text { Calvert } \\
\text { Frederica } \\
\text { Quaternary } \\
\text { Frederica } \\
\text { Quaternary }\end{array}$ \\
\hline
\end{tabular}




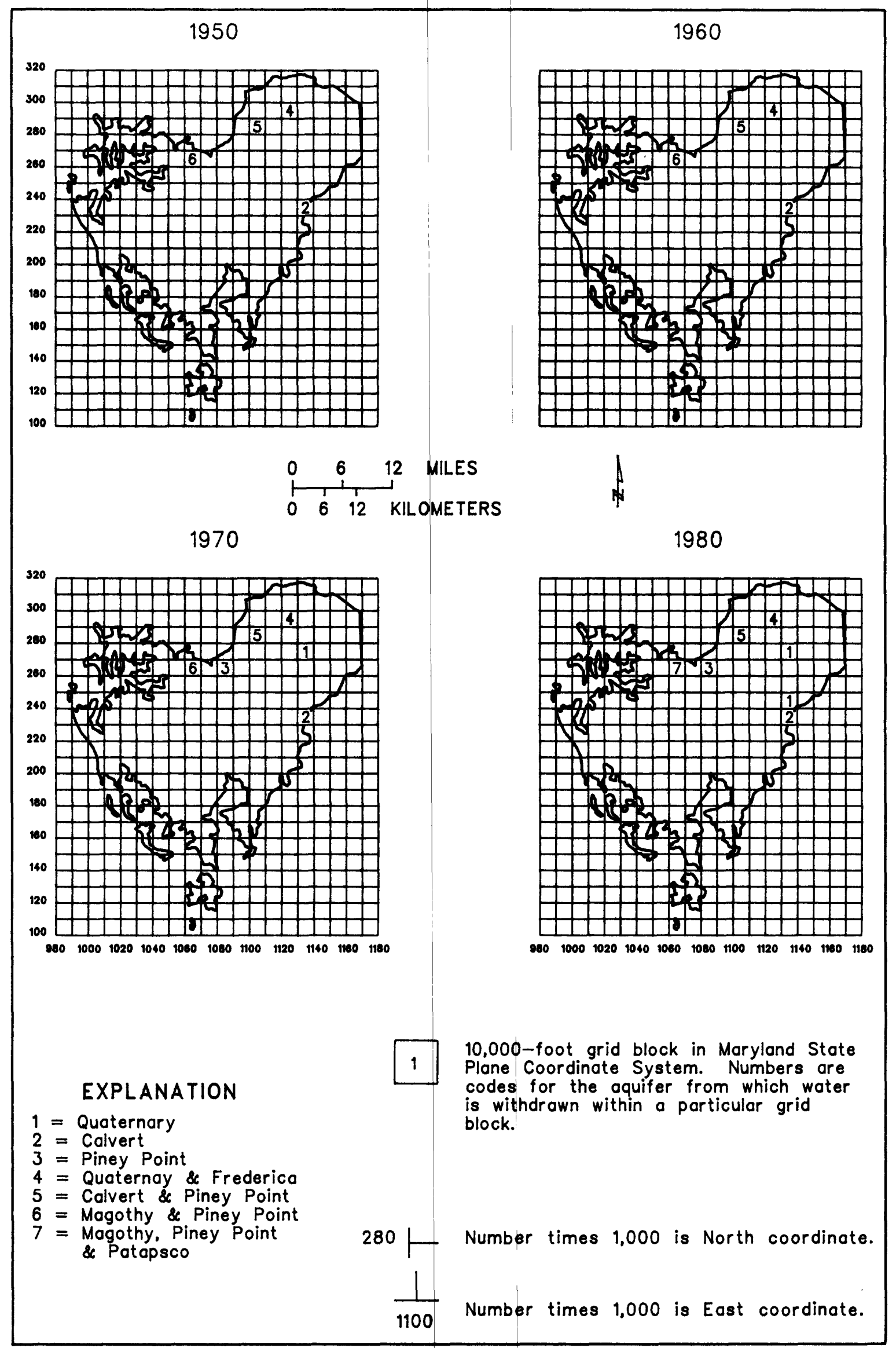

Figure 44.--Locations of large ground-water withdrawals by aquifers in Dorchester County for 1950, 1960, 1970, and 1980. 


\section{HARFORD COUNTY}

The Coastal Plain comprises only about one-fifth of Harford County. Ground-water use in the Coastal Plain area of Harford County from 1950 through 1980 is shown in figure 45. In 1950, the amount of ground water withdrawn was approximately $1.1 \mathrm{Mgal} / \mathrm{d}$ compared to withdrawals of nearly $6.2 \mathrm{Mgal} / \mathrm{d}$ in 1980 . This represents an increase of 464 percent for the three decades.

Since 1950, ground-water use increased in all categories except for military, which declined from approximately $0.3 \mathrm{Mgal} / \mathrm{d}$ in 1950 to less than $0.05 \mathrm{Mgal} / \mathrm{d}$ in 1980. From the mid-1950's, the largest use of ground water was by water suppliers, whose use increased from about $0.3 \mathrm{Mgal} / \mathrm{d}$ in 1950 to $4.3 \mathrm{Mgal} / \mathrm{d}$ in 1980 . See appendix for ground-water withdrawal data for each large user: User's name, appropriation permit number, source aquifer, location on the Maryland Grid Coordinate System, the average daily pumpage, and year pumping began.

The percentages of the total amount of ground water withdrawn for domestic, military, water supplier, and industrial/commercial uses for 1950, 1960, 1970, and 1980 are shown in figure 46 . Military use comprised about 27 percent of the total water withdrawn in 1950, then decreased to only 0.5 percent by 1980 . Withdrawals for water suppliers comprised only 26 percent of the total in 1950 . However, by 1980, this use comprised 69 percent.

\section{Major Aquifers}

Earliest ground-water withdrawals in the Coastal Plain area of Harford County probably came from the surficial (Quaternary) aquifer, primarily the Talbot Formation of the Columbia Group. These shallow sands continued to supply some low-yield water needs, chiefly for domestic use. A few large users were also able to withdraw sufficient quantities of water from the surficial aquifer. As the demand for water by large users increased, the use of deeper aquifers including those of the Potomac Group increased.
Withdrawals from the surficial (Talbot and Quaternary) and Potomac aquifers from 1950 through 1980 are shown in figure 47. From 1950 through 1959, withdrawals from the surficial aquifer averaged about $0.7 \mathrm{Mgal} / \mathrm{d}$. In 1960, pumpage from these aquifers increased to $1.4 \mathrm{Mgal} / \mathrm{d}$, primarily due to increases in withdrawals by the town of Aberdeen (see appendix). By 1980, pumpage had declined to about $1.2 \mathrm{Mgal} / \mathrm{d}$.

Withdrawals from the Potomac aquifers began in 1954 at less than $0.1 \mathrm{Mgal} / \mathrm{d}$ and increased to almost 4.0 $\mathrm{Mgal} / \mathrm{d}$ in 1976. The drop in pumpage in 1975 and the rise in 1976 are probably due to variations in withdrawals by the Harford County Department of Public Works (see appendix). By 1980, withdrawals were about $3.4 \mathrm{Mgal} / \mathrm{d}$.

\section{Locations of Large Ground-Water Withdrawals}

The locations of withdrawals by large users in the Coastal Plain area of Harford County for 1950, 1960, 1970 , and 1980 are shown in figure 48. Table 10 presents water-use data for the large users located within particular grid blocks for the year indicated on the map. In 1950 , the areas of greatest pumpage were located along the Fall Line. Although the number of sites of large withdrawals increased, there was little change in the distribution pattern shown on the maps for 1960, 1970, and 1980.

The locations of withdrawals from individual aquifers supplying the large users in the Coastal Plain area of Harford County (described in table 10 and fig. 48) are shown in figure 49. The distribution of use of the surficial aquifer remained virtually the same for the years shown. Use of the Potomac aquifers did not begin until 1954 (fig. 47) and was limited to areas in the county along the Fall Line. 


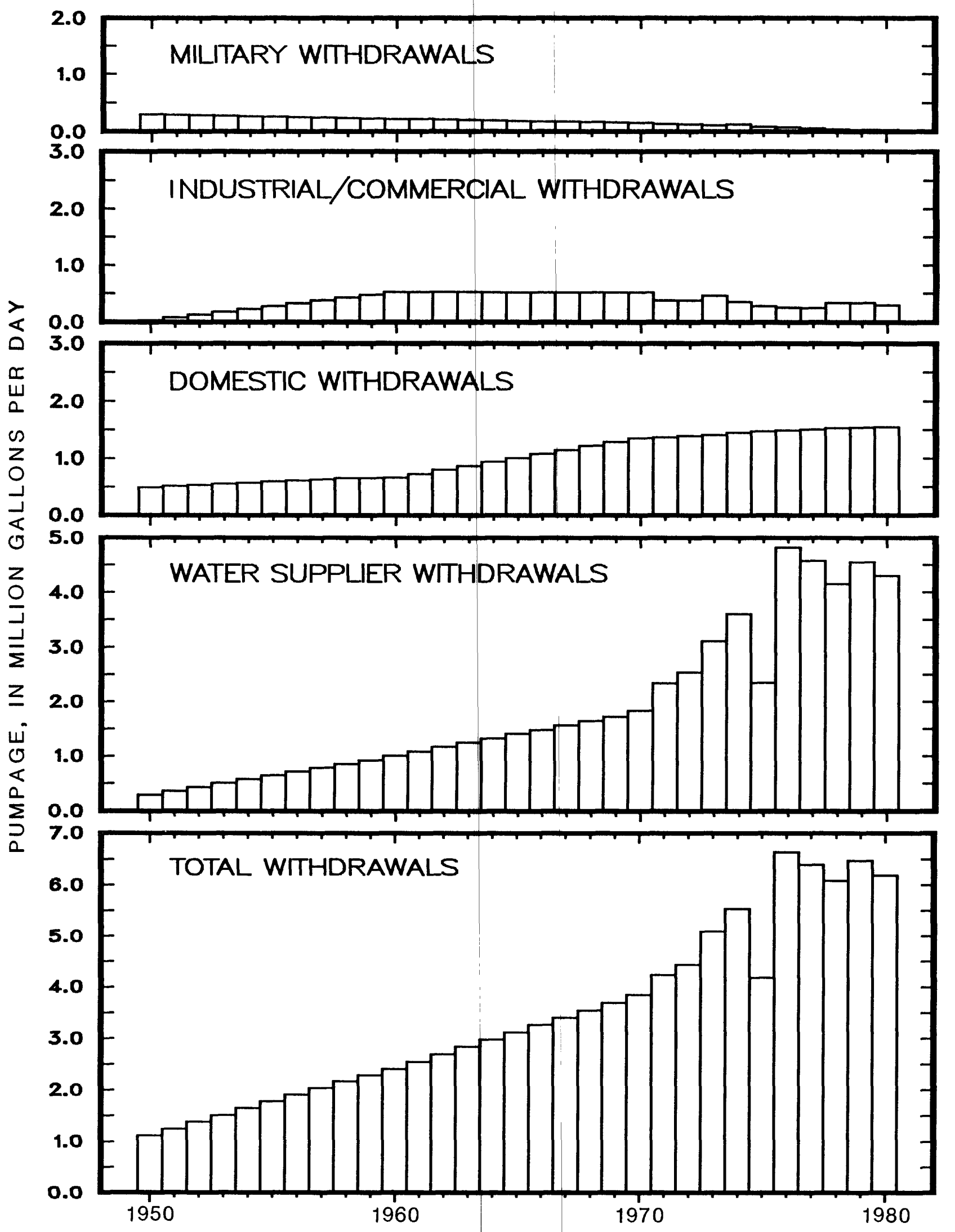

Figure 45.--Ground-water withdrawals by use in the Coastal Plain area of Harford County from 1950 through 1980. 


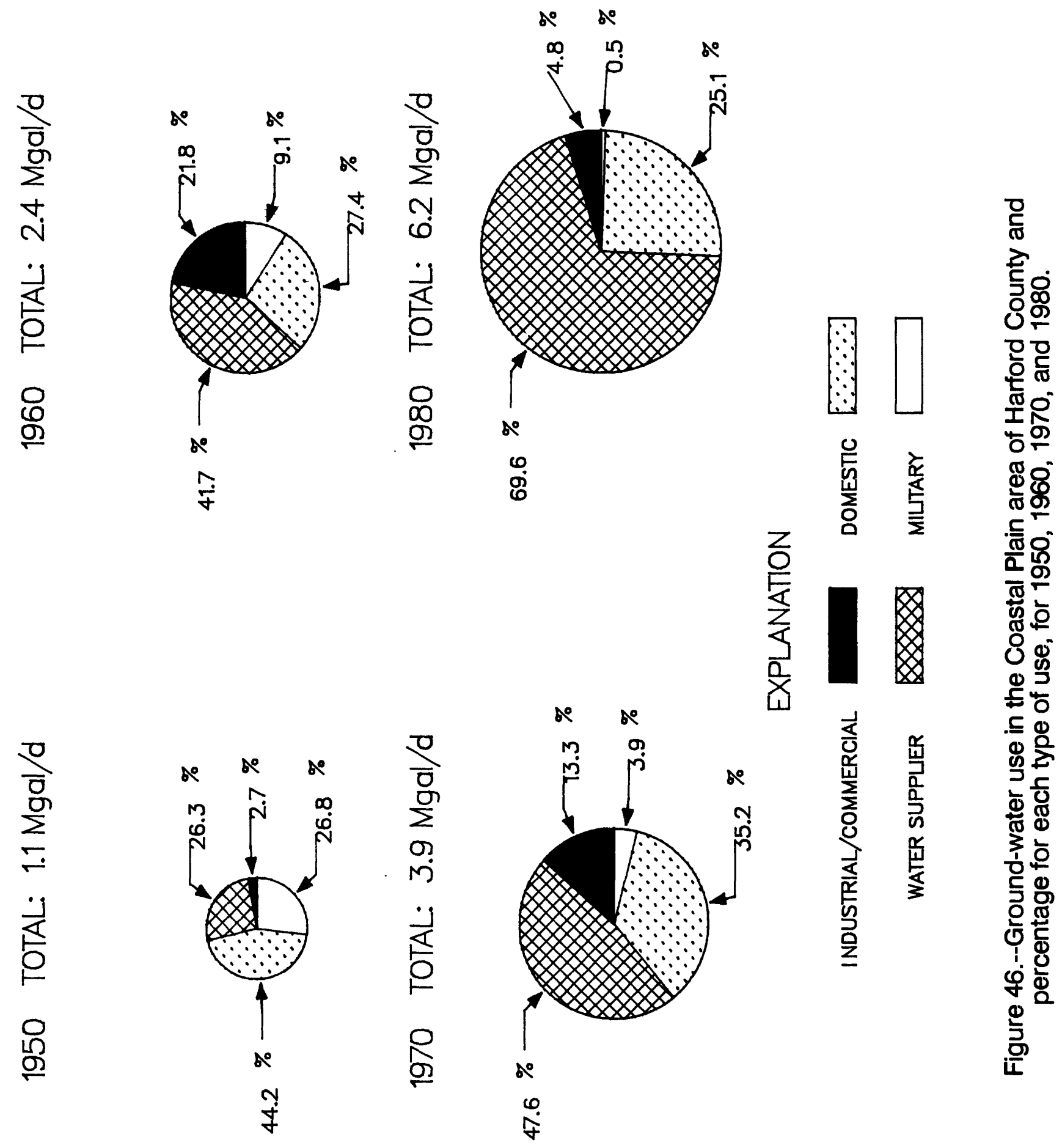



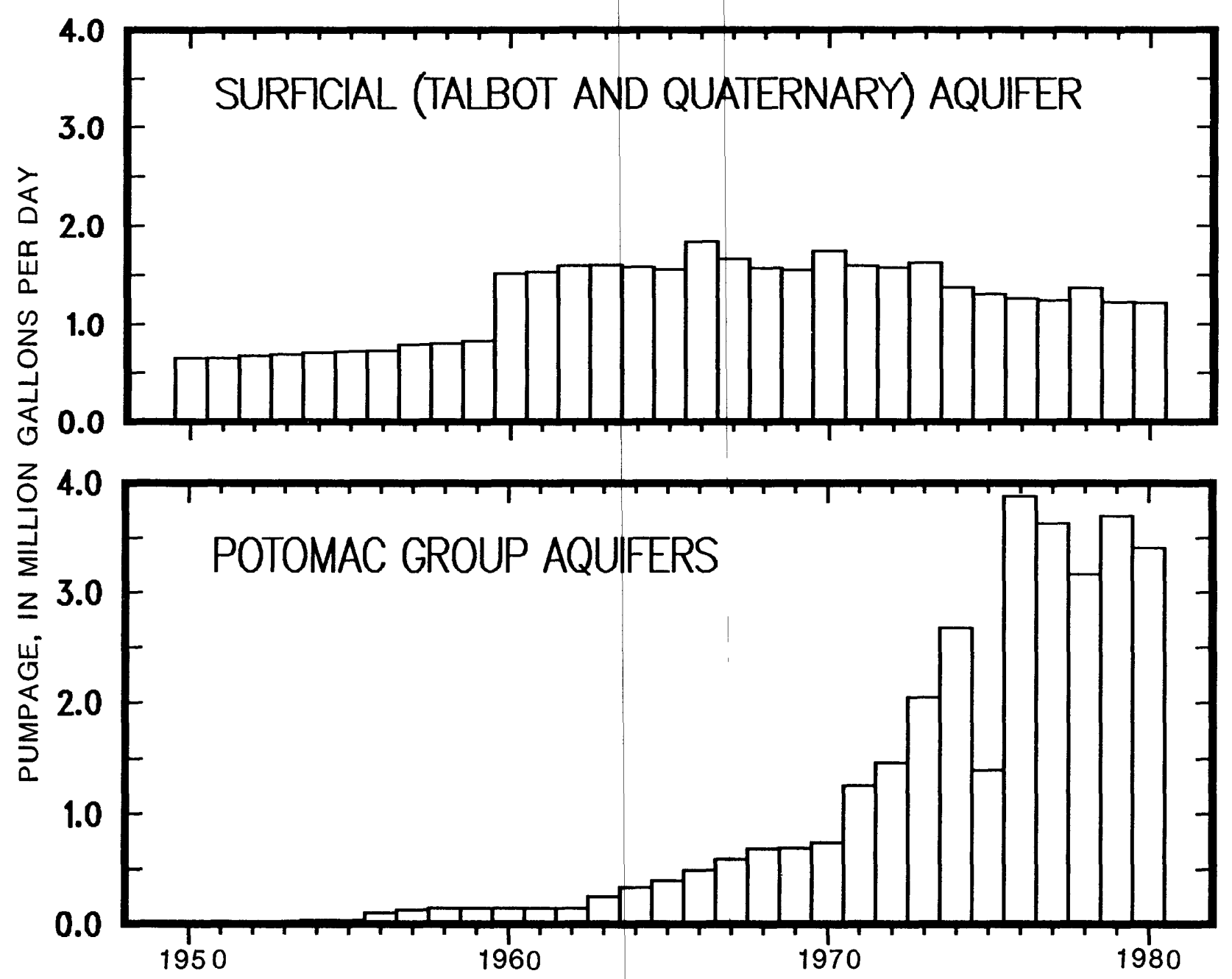

Figure 47.--Large ground-water withdrawals by aquifers in the Coastal Plain area of Harford County from 1950 through 1980. 


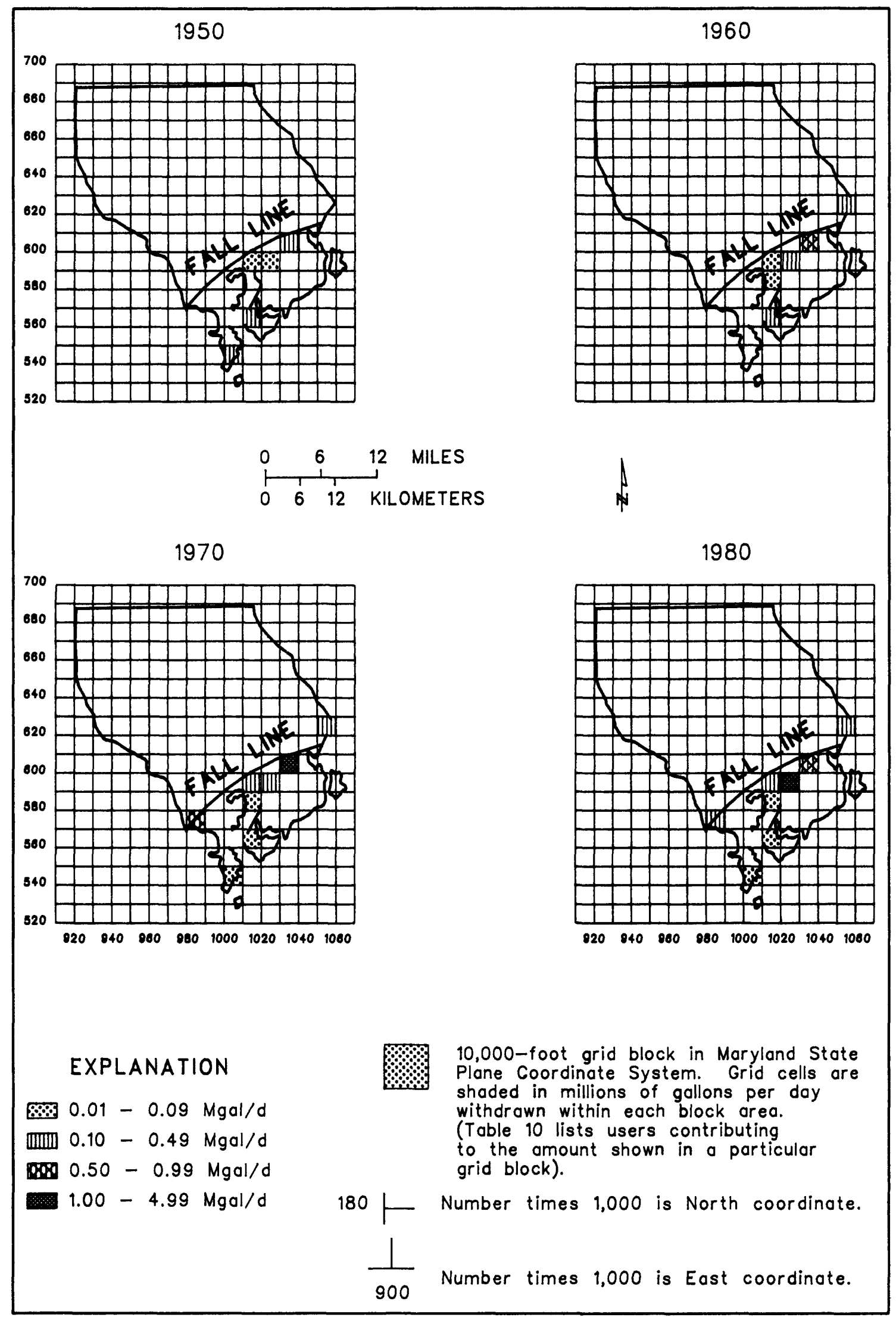

Figure 48.--Locations of large ground-water withdrawals in the Coastal Plain area of Harford County for 1950, 1960, 1970, and 1980. 
Table 10.--Large ground-water users in the Coastal Plain area of Harford County in 1950, 1960, 1970, and 1980 , summarized by the Maryland Grid Coordinate System

\begin{tabular}{|c|c|c|c|c|c|}
\hline Year & Grid & block & User & $\begin{array}{l}\text { Pumpage } \\
\text { (Mgal/d) }\end{array}$ & Aquifer \\
\hline 1950 & $\begin{array}{l}\text { N540 } \\
\text { N560 } \\
\text { N590 } \\
\text { N590 } \\
\text { N600 }\end{array}$ & $\begin{array}{l}\text { E1000 } \\
\text { E1010 } \\
\text { E1010 } \\
\text { E1020 } \\
\text { E1030 }\end{array}$ & $\begin{array}{l}\text { Aberdeen Proving Ground } \\
\text { (Edgewood wells) } \\
\text { Aberdeen Proving Ground } \\
\text { (Aberdeen wells) } \\
\text { Bata Shoe Company, Inc. } \\
\text { F.O. Mitchell \& Bros. Canning Inc. } \\
\text { Aberdeen, Town of }\end{array}$ & $\begin{array}{r}0.16 \\
.14 \\
.02 \\
.04 \\
.29\end{array}$ & $\begin{array}{l}\text { Talbot } \\
\text { Talbot } \\
\text { Talbot } \\
\text { Talbot } \\
\text { Quaternary }\end{array}$ \\
\hline 1960 & $\begin{array}{l}\text { N540 } \\
\text { N560 } \\
\text { N580 } \\
\text { N590 } \\
\text { N590 } \\
\text { N600 } \\
\text { N620 }\end{array}$ & $\begin{array}{l}\text { E1000 } \\
\text { E1010 } \\
\text { E1010 } \\
\text { E1010 } \\
\text { E1020 } \\
\text { E1030 } \\
\text { E1050 }\end{array}$ & $\begin{array}{l}\text { Aberdeen Proving Ground, } \\
\text { (Edgewood wells) } \\
\text { Aberdeen Proving Ground, } \\
\text { (Aberdeen wells) } \\
\text { Willoughby Beach Water Company } \\
\text { Bata Shoe Company, Inc. } \\
\text { Interpace Corporation } \\
\text { F.O. Mitchell \& Bros. Canning Inc. } \\
\text { Aberdeen, Town of } \\
\text { J.M. Huber Corporation }\end{array}$ & $\begin{array}{r}0.15 \\
.13 \\
.04 \\
.04 \\
.11 \\
.04 \\
.97 \\
.20\end{array}$ & $\begin{array}{l}\text { Talbot } \\
\text { Talbot } \\
\text { Potomac Group } \\
\text { Talbot } \\
\text { Potomac Group } \\
\text { Talbot } \\
\text { Quaternary } \\
\text { Talbot }\end{array}$ \\
\hline 1970 & $\begin{array}{l}\text { N540 } \\
\text { N560 } \\
\text { N570 } \\
\text { N580 } \\
\text { N590 } \\
\text { N590 } \\
\text { N600 } \\
\text { N620 }\end{array}$ & $\begin{array}{l}\text { E1000 } \\
\text { E1010 } \\
\text { E980 } \\
\text { E1010 } \\
\text { E1010 } \\
\text { E1020 } \\
\text { E1030 } \\
\text { E1050 }\end{array}$ & $\begin{array}{l}\text { Aberdeen Proving Ground, } \\
\text { (Edgewood wells) } \\
\text { Aberdeen Proving Ground, } \\
\text { (Aberdeen wells) } \\
\text { Joppatowne Utilities } \\
\text { Willoughby Beach Water Company } \\
\text { Long Bar Harbor, } \\
\text { Harford Co. Metro. Comm. } \\
\text { Bata Shoa Company, Inc. } \\
\text { Interpace Corporation } \\
\text { F.O. Mitchell \& Bros. Canning Inc. } \\
\text { Aberdeen, Town of } \\
\text { J.M. Huber Corporation }\end{array}$ & $\begin{array}{r}0.08 \\
.07 \\
.54 \\
.04 \\
.05 \\
.05 \\
.12 \\
.02 \\
1.20 \\
.33\end{array}$ & $\begin{array}{l}\text { Talbot } \\
\text { Talbot } \\
\text { Potomac Group } \\
\text { Potomac Group } \\
\text { Potomac Group } \\
\text { Talbot } \\
\text { Potomac Group } \\
\text { Talbot } \\
\text { Quaternary } \\
\text { Talbot }\end{array}$ \\
\hline 1980 & $\begin{array}{l}\text { N540 } \\
\text { N560 } \\
\text { N570 } \\
\text { N580 } \\
\text { N590 } \\
\text { N590 }\end{array}$ & $\begin{array}{l}\text { E1000 } \\
\text { E1010 } \\
\text { E980 } \\
\text { E1010 } \\
\text { E1010 } \\
\text { E1020 }\end{array}$ & $\begin{array}{l}\text { Aberdeen Proving Ground, } \\
\text { (Edgewood wells) } \\
\text { Aberdeen Proving Ground, } \\
\text { (Aberdeen wells) } \\
\text { Joppatowne Ut1lities } \\
\text { Willoughby Beach Water Company } \\
\text { Long Bar Harbor, } \\
\text { Harford Co., Metro. Comm. } \\
\text { Bata Shoe Company, Inc. } \\
\text { Short Lane, } \\
\text { Harford Co., Metro. Comm. } \\
\text { Perryman, } \\
\text { Harford Co. Dept. of Public Works } \\
\text { Interpace Corporation } \\
\text { Aberdeen, Town of } \\
\text { J.M. Huber Corporation }\end{array}$ & $\begin{array}{r}0.02 \\
.02 \\
.26 \\
.04 \\
.11 \\
.02 \\
1.78 \\
1.13 \\
.10 \\
.98 \\
.18\end{array}$ & $\begin{array}{l}\text { Talbot } \\
\text { Talbot } \\
\text { Potomac Group } \\
\text { Potomac Group } \\
\text { Potomac Group } \\
\text { Talbot } \\
\text { Potomac Group } \\
\text { Potomac Group } \\
\text { Potomac Group } \\
\text { Quaternary } \\
\text { Talbot }\end{array}$ \\
\hline
\end{tabular}




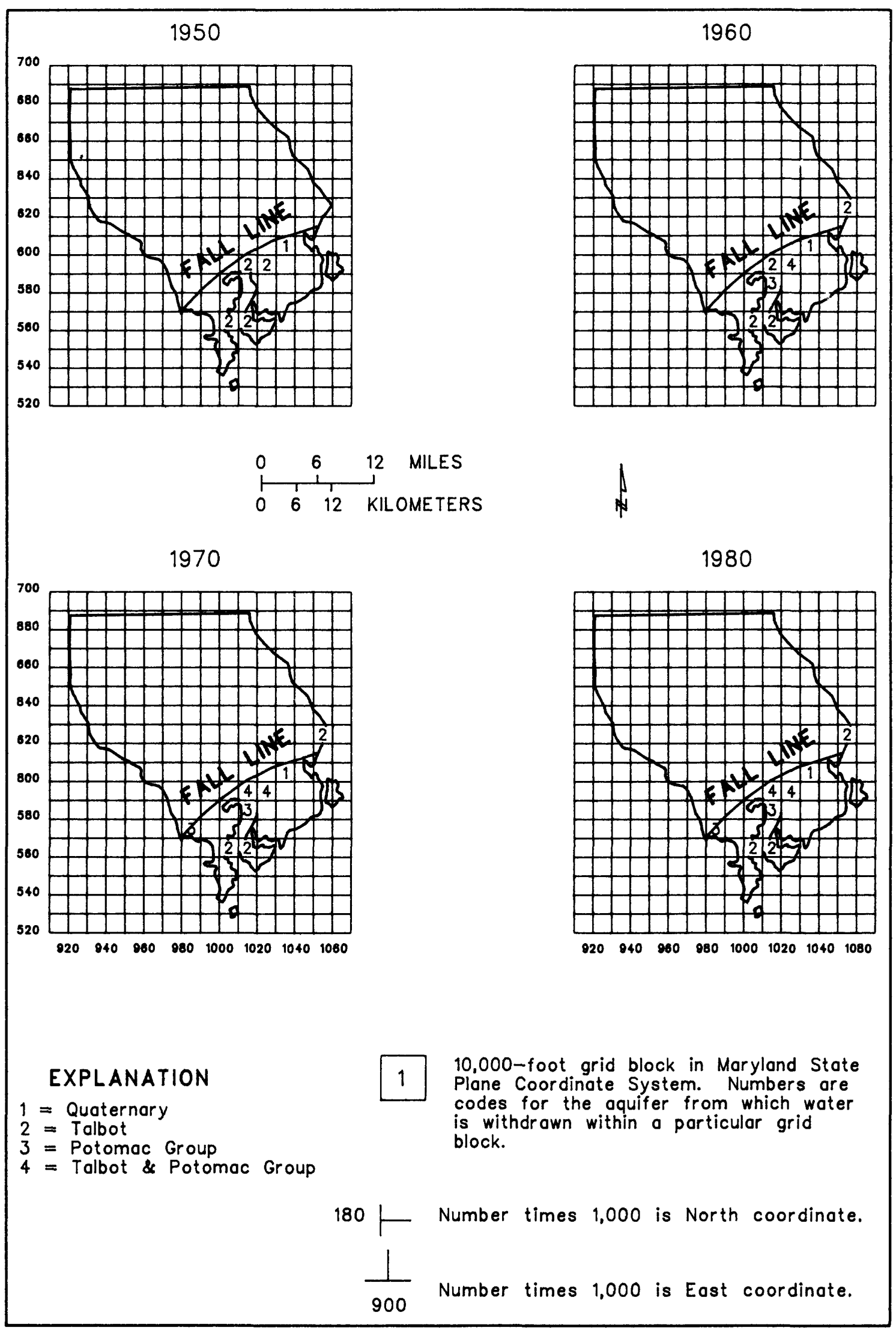

Figure 49.--Locations of large ground-water withdrawals by aquifers in the Coastal Plain area of Harford County for 1950, 1960, 1970, and 1980. 


\section{KENT COUNTY}

Ground-water use in Kent County from 1950 through 1980 is shown in figure 50. In 1950, the amount of ground water withdrawn was approximately 1.4 $\mathrm{Mgal} / \mathrm{d}$ compared to withdrawals of nearly $3.5 \mathrm{Mgal} / \mathrm{d}$ in 1980. This represents an increase of 150 percent for the three decades.

Since 1950, water use in Kent County has increased in nearly all categories. Figure 50 shows that during the early 1950's, the largest use of ground water was domestic (approximately $0.7 \mathrm{Mgal} / \mathrm{d}$ ). Withdrawals for this use remained relatively the same until 1980 . Pumpage by water suppliers also remained about the same $(0.4$ $\mathrm{Mgal} / \mathrm{d}$ ) to 1970 . However, increases in withdrawals for this use occurred over the next 10 years, and, by 1980 , about $0.8 \mathrm{Mgal} / \mathrm{d}$ was being pumped.

From the mid-1950's until 1971, the largest withdrawals were for industrial/commercial use. Following the closing of several canneries and processing plants during the early 1970's, however, withdrawals declined from about $1.0 \mathrm{Mgal} / \mathrm{d}$ in 1963 to about 0.6 $\mathrm{Mgal} / \mathrm{d}$ in 1980.

Water withdrawn for irrigation was greatest during the period $1964(0.3 \mathrm{Mgal} / \mathrm{d})$ to $1980(1.1 \mathrm{Mgal} / \mathrm{d})$. Although there have been no precise measurements of the amounts of water withdrawn by individual irrigators, methods of collecting and reporting these data have improved since the early 1950's. However, the most reliable data are from 1970 to 1980 . See appendix for ground-water withdrawal data for each large user: User's name, appropriation permit number, source aquifer, location on the Maryland Grid Coordinate System, average daily pumpage, and year pumping began.

The percentages of the total amount of ground water withdrawn for domestic, water supplier, industrial/commercial, and irrigation uses are shown in figure 51 . In 1950, 50 percent of the total water pumped was for domestic use. However, this percentage dropped the following years to about 28 percent by 1980. The percentage of water used for irrigation, on the other hand, increased from 10 percent in 1960 to about 31 percent in 1980.

\section{Major Aquifers}

Many domestic withdrawals in Kent County were from shallow wells (from about 15 to $45 \mathrm{ft}$ deep) tapping the surficial aquifer. Deeper aquifers including the
Aquia, Severn, Magothy, and Patapsco were more widely used by large users. Large user withdrawals by aquifer from 1950 through 1980 are shown in figure 52.

The Aquia aquifer was a major source of water for large users for the 30 years shown. The amount of its use remained relatively the same during the decade 1950 to 1960 (around $0.4 \mathrm{Mgal} / \mathrm{d}$ ), then increased in 1960 to about $0.7 \mathrm{Mgal} / \mathrm{d}$, and continued to increase through 1980 to about $1.1 \mathrm{Mgal} / \mathrm{d}$. Withdrawals from the Severn aquifer were less than $0.01 \mathrm{Mgal} / \mathrm{d}$ until 1978 ; from then to 1980 , pumpage averaged about 0.01 $\mathrm{Mgal} / \mathrm{d}$.

Use of the Magothy aquifer stayed virtually the same from 1950 through 1970 (at approximately 0.3 $\mathrm{Mgal} / \mathrm{d}$ ), when its use declined. From 1971 through 1980 , withdrawals averaged about $0.15 \mathrm{Mgal} / \mathrm{d}$.

Pumpage from the Patapsco aquifer was relatively constant (approximately $0.1 \mathrm{Mgal} / \mathrm{d}$ ) for most of the 30-year period. However, withdrawals did increase to nearly $0.2 \mathrm{Mgal} / \mathrm{d}$ during the last few years of record.

\section{Locations of Large Ground-Water Withdrawals}

The locations of withdrawals by large users in Kent County for 1950, 1960,1970, and 1980 are shown in figure 53. Table 11 presents water-use data for the large users located within particular grid blocks for the year indicated on the map.

In 1950, the locations of large withdrawals were near the northern border of the county, along the southwestern border near the Chesapeake Bay, and along the east-central border. This distribution pattern remained relatively the same until 1970 . However, the maps for 1970 and 1980 show increases in withdrawal sites in the central part of the county.

The locations of withdrawals from individual aquifers supplying the large users in Kent County (described in table 11 and fig. 53) are shown in figure 54. For the 4 years shown, the Aquia aquifer was used primarily in the central and southern parts of the county. Large withdrawals from the Severn aquifer appear only on the map for 1980, and at a single location in the central part of the county. The Magothy aquifer had the widest distribution of use, whereas the Patapsco aquifer was used in only one location in the southwestern part of the county. 


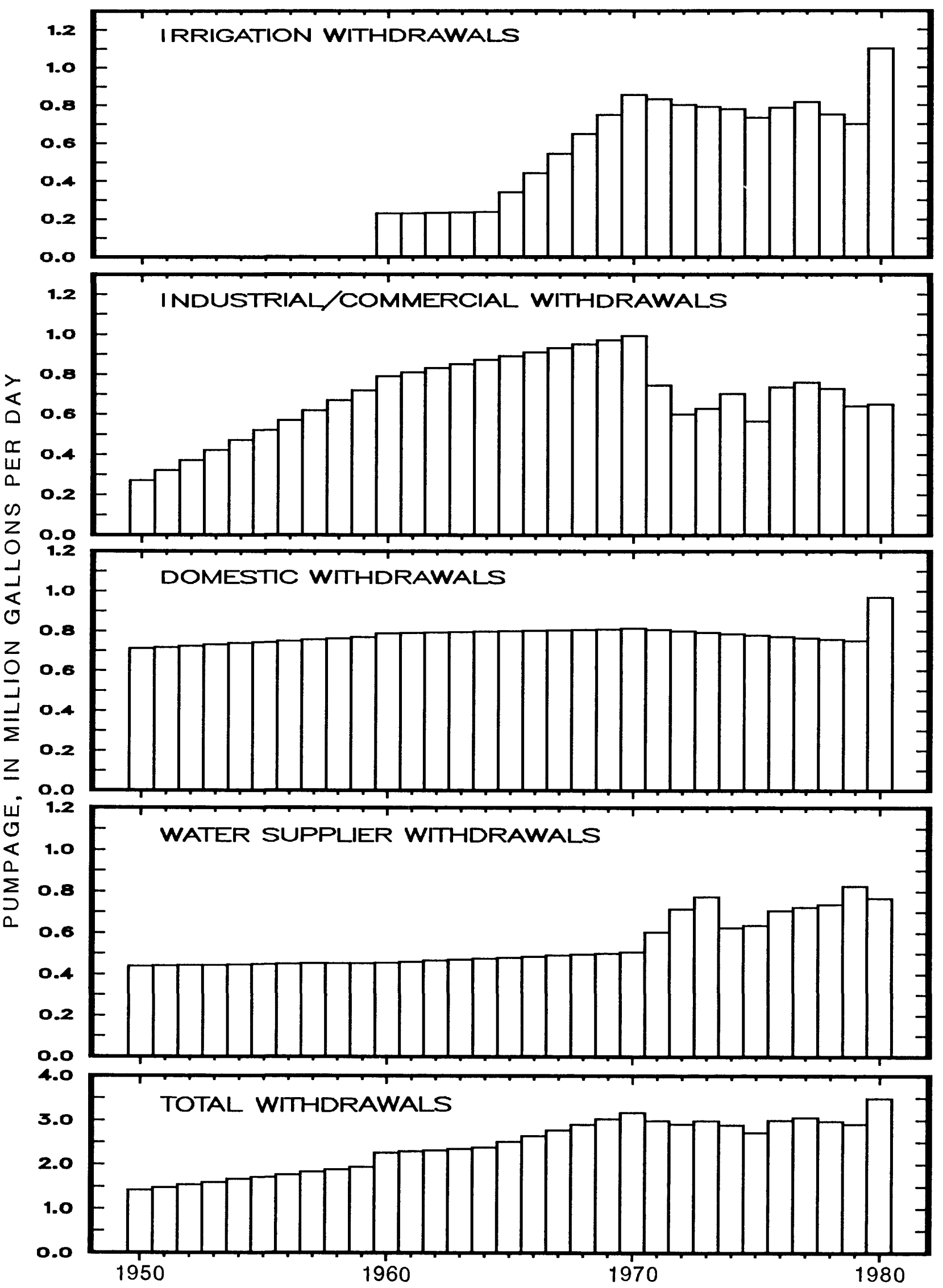

Figure 50.--Ground-water withdrawals by use in Kent County from 1950 through 1980. 


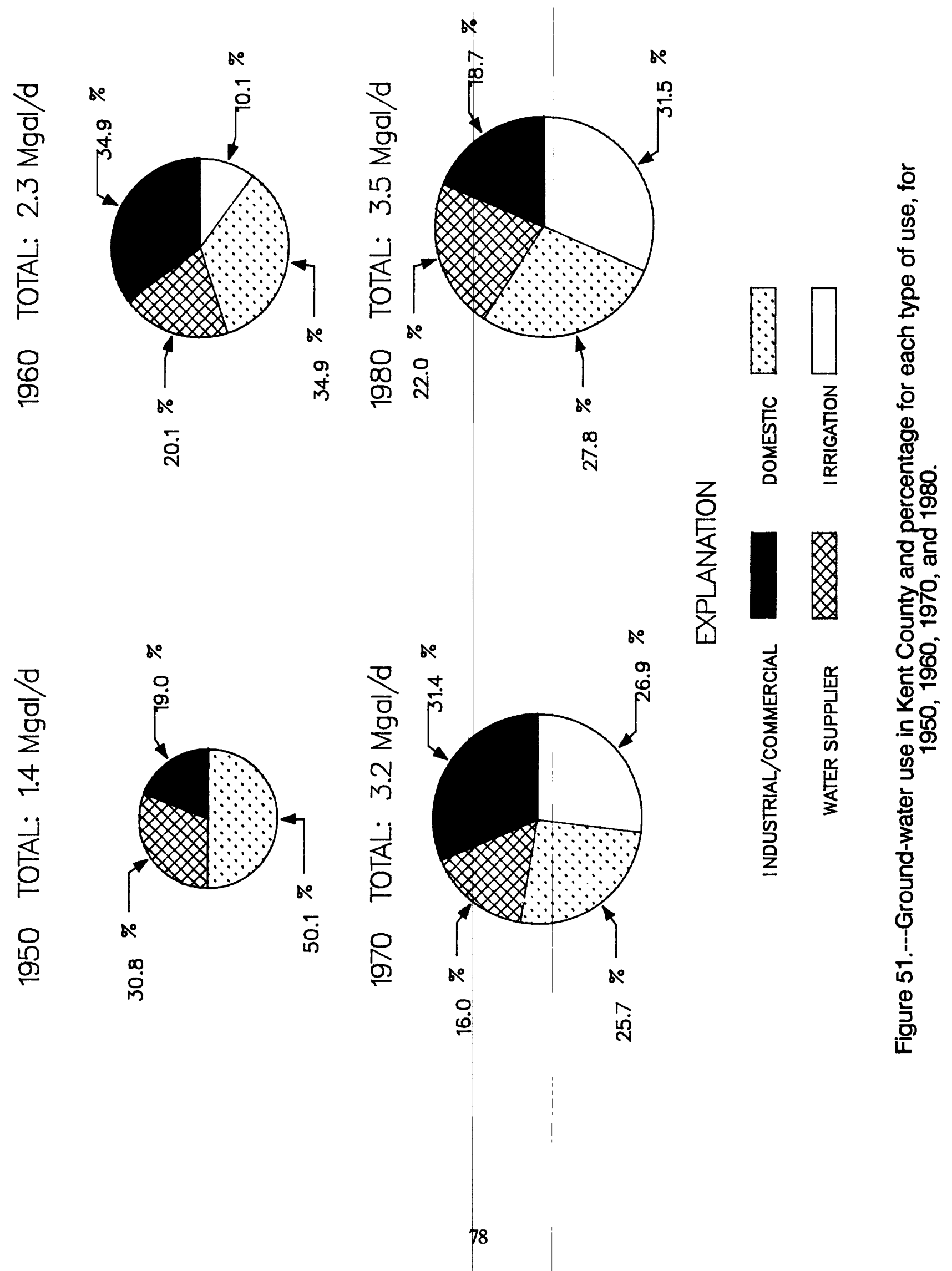




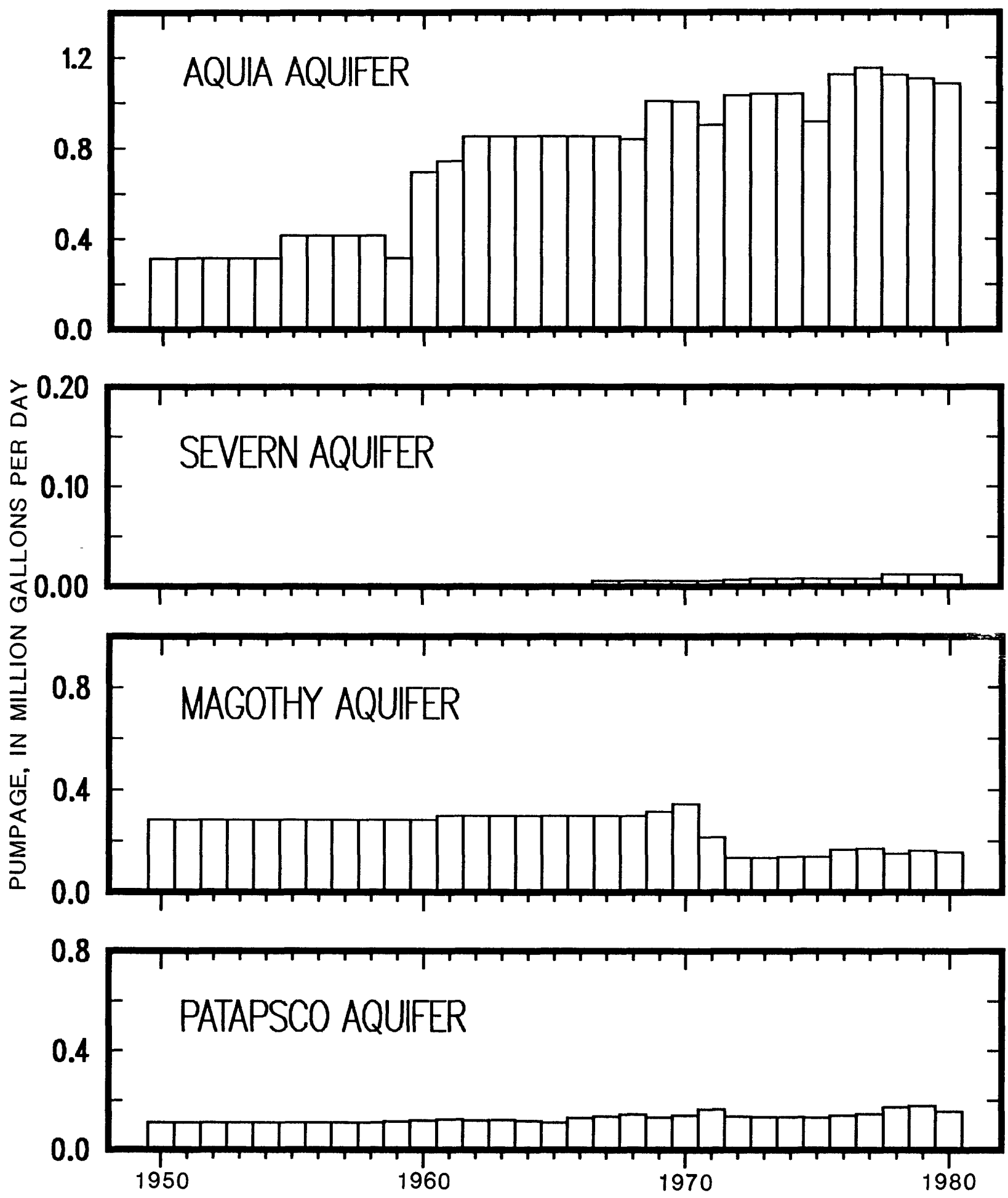

Figure 52.--Large ground-water withdrawals by aquifers in Kent County from 1950 through 1980. 


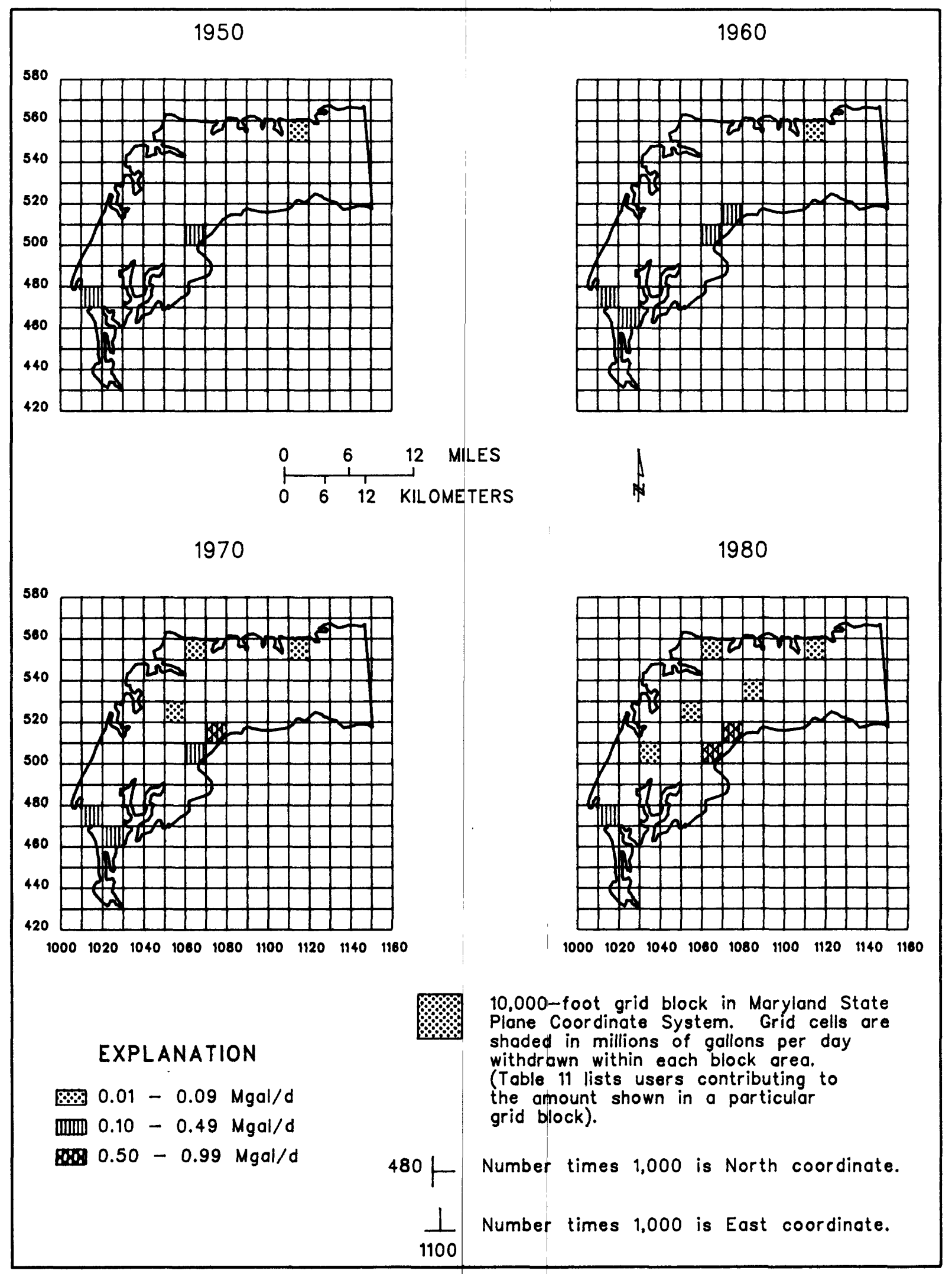

Figure 53.--Locations of large ground-water withdrawals in Kent County for 1950, 1960, 1970, and 1980. 
Table 11.--Large ground-water users in Kent County in 1950, 1960, 1970, and 1980, summarized by the Maryland Grid Coordinate System

\begin{tabular}{|c|c|c|c|c|}
\hline Year & Grıd block & User & $\begin{array}{l}\text { Pumpage } \\
\text { (Mgal/d) }\end{array}$ & Aquifer \\
\hline 1950 & $\begin{array}{l}\text { N470 E1010 } \\
\text { N500 E1060 } \\
\text { N550 E1110 }\end{array}$ & $\begin{array}{l}\text { Rock Hall, Town of } \\
\text { Kent Packing Company } \\
\text { Ivens \& Eudson Oyster Company } \\
\text { Vita Food Products, Incorporated } \\
\text { Chestertown Utilities Commission } \\
\text { Galena, Town of }\end{array}$ & $\begin{array}{r}0.11 \\
.15 \\
.02 \\
.10 \\
.32 \\
.01\end{array}$ & $\begin{array}{l}\text { Patapsco } \\
\text { Magothy } \\
\text { Magothy } \\
\text { Magothy } \\
\text { Aquia } \\
\text { Magothy }\end{array}$ \\
\hline 1960 & $\begin{array}{l}\text { N460 } \\
\text { N470 } \\
\text { E1010 } \\
\text { N500 } \\
\text { N1060 } \\
\text { N510 } \\
\text { N550 } \\
\text { E11070 }\end{array}$ & $\begin{array}{l}\text { C.H. Ashley \& Son Oyster Company } \\
\text { Rock Hall, Town of } \\
\text { Kent Packing Companay } \\
\text { Ivens \& Hudson Oyster Company } \\
\text { Vita Food Products, Incorporated } \\
\text { Chestertown Utilities Commission } \\
\text { Campbell Soup Company } \\
\text { Galena, Town of }\end{array}$ & $\begin{array}{r}0.16 \\
.12 \\
.15 \\
.02 \\
.10 \\
.32 \\
.22 \\
.01\end{array}$ & $\begin{array}{l}\text { Aquia } \\
\text { Patapsco } \\
\text { Magothy } \\
\text { Magothy } \\
\text { Magothy } \\
\text { Aqui a } \\
\text { Aquia } \\
\text { Magothy }\end{array}$ \\
\hline 1970 & $\begin{array}{ll}\text { N460 } & E 1020 \\
\text { N470 } & \mathrm{E} 1010 \\
\text { N500 } & \mathrm{E} 1060 \\
\text { N510 } & \mathrm{E} 1070 \\
\text { N520 } & \mathrm{E} 1050 \\
\text { N550 } & \mathrm{E} 1110 \\
\text { N560 } & \mathrm{E} 1060\end{array}$ & $\begin{array}{l}\text { C.H. Ashley \& Son Oyster Company } \\
\text { Rock Hall, Town of } \\
\text { Kent Packing Company } \\
\text { Ivens \& Hudson Oyster Company } \\
\text { Vita Food Products, Incorporated } \\
\text { Chestertown Utilities Commission } \\
\text { Campbell Soup Company } \\
\text { Tenneco Chemi cals, Incorporated } \\
\text { Galena, Town of } \\
\text { Betterton, Town of }\end{array}$ & $\begin{array}{l}0.10 \\
.14 \\
.15 \\
.02 \\
.10 \\
.32 \\
.59 \\
.03 \\
.03 \\
.02\end{array}$ & $\begin{array}{l}\text { Aquia } \\
\text { Patapsco } \\
\text { Magothy } \\
\text { Magothy } \\
\text { Magothy } \\
\text { Aquia } \\
\text { Aquia } \\
\text { Magothy } \\
\text { Magothy } \\
\text { Magothy }\end{array}$ \\
\hline 1980 & $\begin{array}{ll}\text { N470 } & \mathrm{E} 1010 \\
\text { N500 } & \mathrm{E} 1030 \\
& \\
\text { N500 } & \mathrm{E} 1060 \\
\text { N510 } & \mathrm{E} 1070 \\
\text { N520 } & \mathrm{E} 1050 \\
\text { N530 } & \mathrm{E} 1080 \\
\text { N550 } & \mathrm{E} 1110 \\
\text { N560 } & \mathrm{E} 1060\end{array}$ & $\begin{array}{l}\text { Rock Hall, Town of } \\
\text { Fairlee District, } \\
\text { Kent County Sanitary District } \\
\text { Chestertown Ut1lities Commission } \\
\text { Campbell Soup Company } \\
\text { Tenneco Chemicals, Incorporated } \\
\text { Kennedyville, } \\
\text { Kent County Sanitary District } \\
\text { Galena, Town of } \\
\text { Betterton, Town of }\end{array}$ & $\begin{array}{r}0.15 \\
.04 \\
.50 \\
.58 \\
.07 \\
.01 \\
.04 \\
.02\end{array}$ & $\begin{array}{l}\text { Patapsco } \\
\text { Magothy } \\
\text { Aquia } \\
\text { Aquia } \\
\text { Magothy } \\
\text { Severm } \\
\text { Magothy } \\
\text { Magothy }\end{array}$ \\
\hline
\end{tabular}




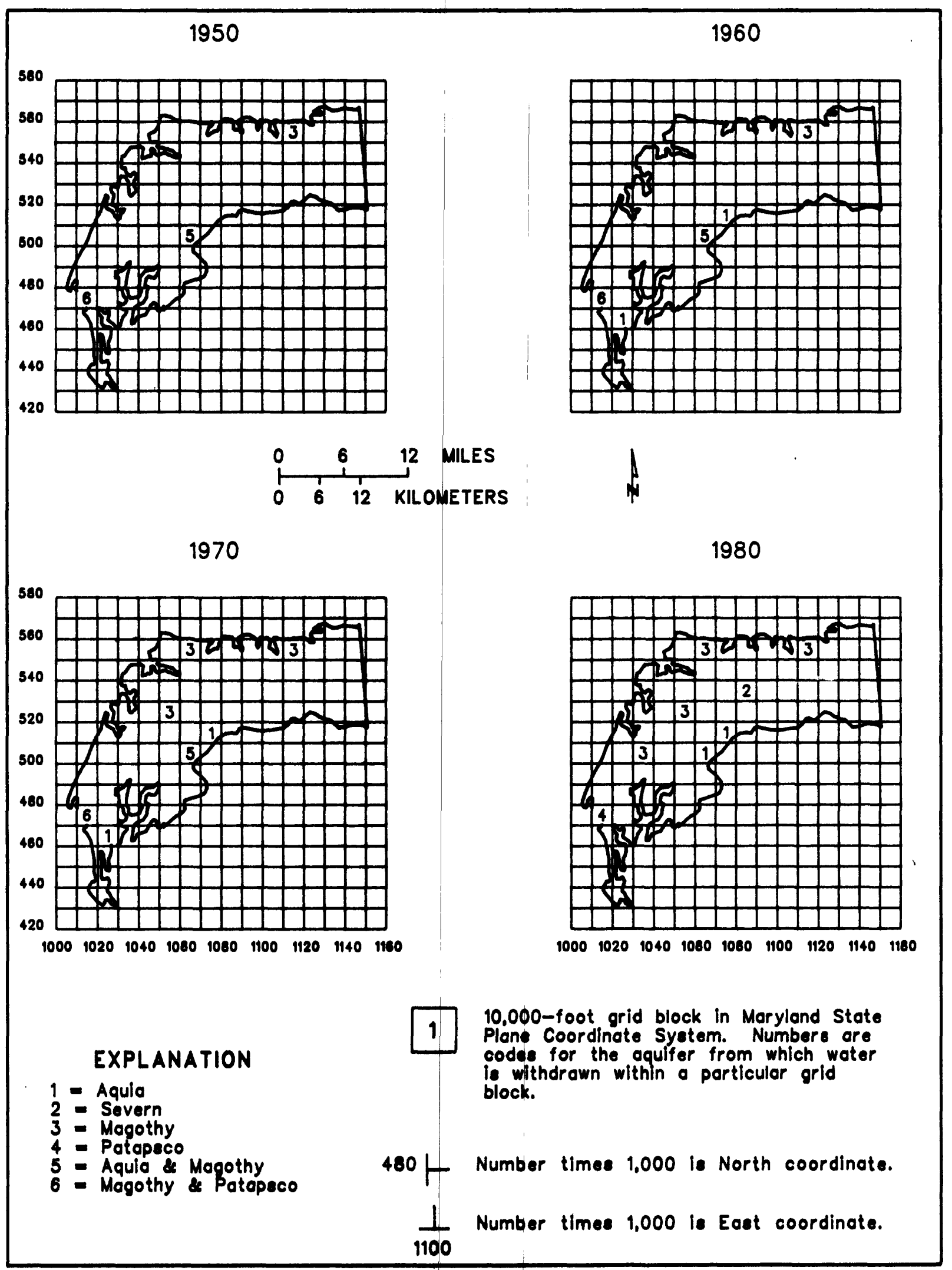

Figure 54.--Locations of large ground-water withdrawals by aquifers in Kent County for $1950,1960,1970$, and 1980. 


\section{PRINCE GEORGES COUNTY}

In the early development of Prince Georges County, ground water supplied most of the needs of the inhabitants. However, as the population grew, particularly around the Washington, D.C. area, and demand for water increased, the Maryland General Assembly in 1918 established the Washington Suburban Sanitary Commission (WSSC) to be responsible for supplying water (surface water from the Potomac and Patapsco Rivers) to the suburban areas of Prince Georges and Montgomery Counties (Mack, 1966). Since that time, WSSC has extended waterlines throughout most of Prince Georges County, which, as of 1980, served about 80 percent of the population. Nevertheless, ground water continued to supply some large users and individual houses and farms. Much of the punipage for domestic use was from shallow wells (from about 15 to $45 \mathrm{ft}$ deep) tapping the surficial aquifer. Deeper aquifers including the Patuxent, Patapsco, and Magothy were more widely used by large ground-water users.

Ground-water use in the Coastal Plain area of Prince Georges County from 1950 through 1980 is shown in figure 55 . In 1950, the amount of ground water withdrawn was approximately $6.0 \mathrm{Mgal} / \mathrm{d}$. By 1970 , withdrawals had increased to nearly $10.0 \mathrm{Mgal} / \mathrm{d}$. After that year, pumpage started to decline so that by 1980 it had fallen to about $7.2 \mathrm{Mgal} / \mathrm{d}$, or just more than 1.0 $\mathrm{Mgal} / \mathrm{d}$ greater than it had been in 1950. A major factor in this decline was the expansion of water service by WSSC to many areas that previously had been supplied by individual wells or by wells of public and private water compamies.

Pumpage by water suppliers was about $0.7 \mathrm{Mgal} / \mathrm{d}$ in 1950. There was little change in withdrawals until around 1960, at which time a central water supply was put into service at Bowie (see appendix). Pumpage then increased considerably over the next decade so that by 1970 , approximately $4.1 \mathrm{Mgal} / \mathrm{d}$ was withdrawn by public suppliers, most of which was from the Bowie supply. See appendix for ground-water withdrawal data for each large user: User's name, appropriation permit number, source aquifer, location on the Maryland Grid Coordinate System, average daily punipage, and year pumping began.

The percentages of the total amount of ground water withdrawn for domestic, military, water supplier, and industrial/commercial uses for years 1950 to 1980 are shown in figure 56. As shown, domestic use comprised about 74 percent of the total water withdrawn in 1950. By 1980 , however, the fraction was only about 35 percent, whereas the percentage for water suppliers increased from 12 percent in 1950 to 40 percent in 1980.

\section{Major Aquifers}

Many domestic withdrawals in Prince Georges County were from shallow wells (from about 15 to $45 \mathrm{ft}$ deep) tapping the surficial aquifer. Deeper aquifers including the Magothy, Patapsco, and Patuxent were more widely used by large users not supplied by WSSC. Large user withdrawals by aquifer from 1940 through 1980 are shown in figure 57.

Punpage from the Magothy aquifer showed little change from 1940 to 1959 . After that time, withdrawals increased from about $0.5 \mathrm{Mgal} / \mathrm{d}$ in 1959 to nearly 1.5 $\mathrm{Mgal} / \mathrm{d}$ in 1980, with a peak punpage of about 1.7 $\mathrm{Mgal} / \mathrm{d}$ in 1976.

Continuous use of the Patapsco aquifer by large users began about 1958. By the early 1970's, punipage had increased to almost $2 \mathrm{Mgal} / \mathrm{d}$. Withdrawals remained more than $1 \mathrm{Mgal} / \mathrm{d}$ through the 1970 's. However, in 1980 there was a significant drop in pumpage to about $0.5 \mathrm{Mgal} / \mathrm{d}$. This was due to a decline in pumpage from the Patapsco aquifer at Bowie (see appendix).

Pumpage from the Patuxent aquifer began about 1946 and gradually increased until 1960. From 1960 to 1970, significant increases are shown, especially after 1965. During that year, the city of Bowie began using the Patuxent aquifer.

\section{Locations of Large Ground-Water Withdrawals}

The locations of withdrawals by large users in Prince Georges County for 1950, 1960, 1970, and 1980 are shown in figure 58. Table 12 presents water-use data for the large users located within particular grid blocks for the year indicated on the map. The maps show that the pattern of distribution of pumpage developed around the perimeter areas of the county which are generally not served by WSSC.

The locations of withdrawals from individual aquifers supplying the large users in Prince Georges County (described in table 12 and fig. 58) are shown in figure 59. The Magothy aquifer was used mostly in the south-central to southeastern part of the county. Locations of withdrawals from the Patapsco aquifer were primarily in the Bowie area and the southwestern part of the county. For the most part, the Patuxent aquifer was used in the northern part of the county. 


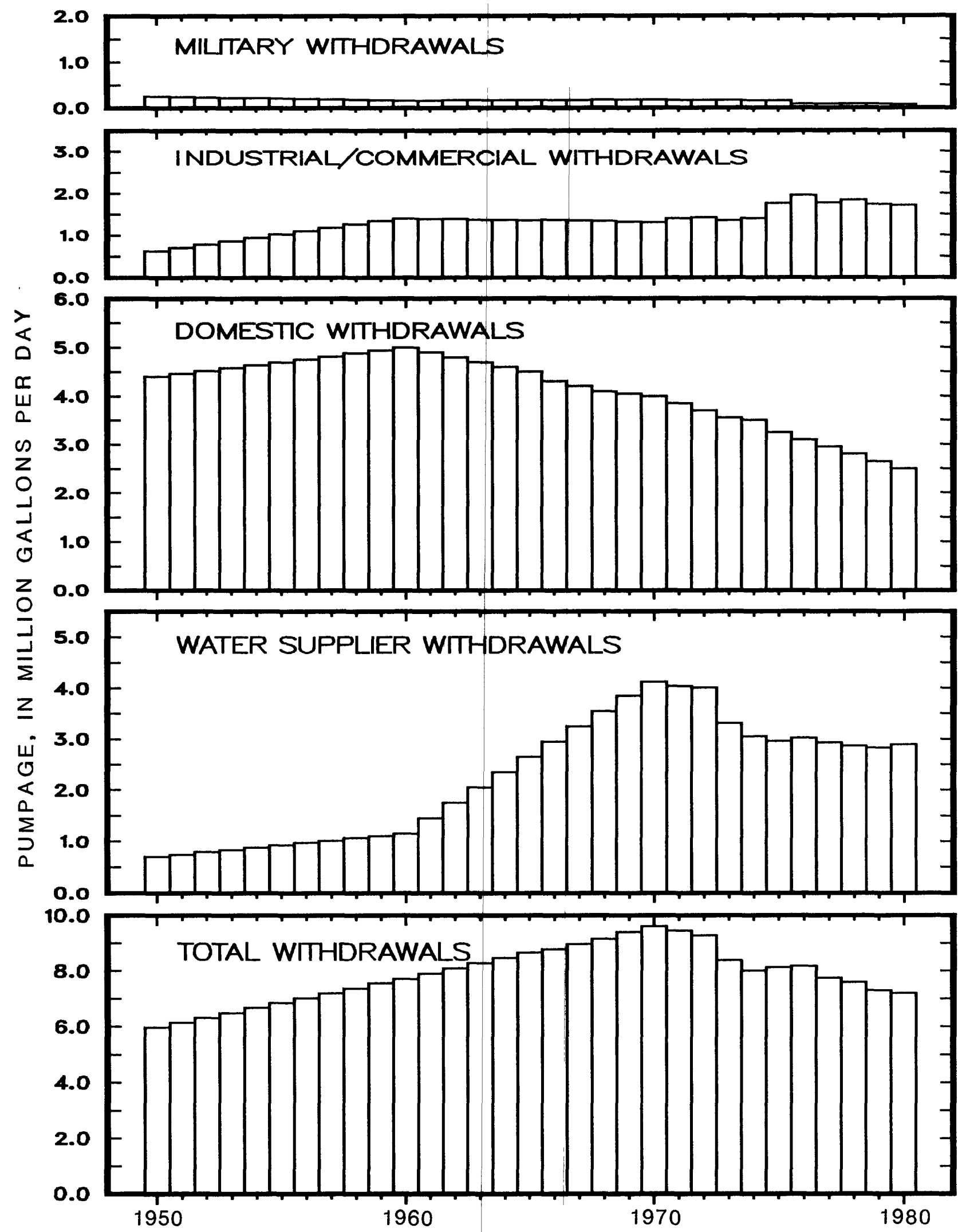

Figure 55.--Ground-water withdrawals by use in the Coastal Plain area of Prince Georges County from 1950 through 1980. 

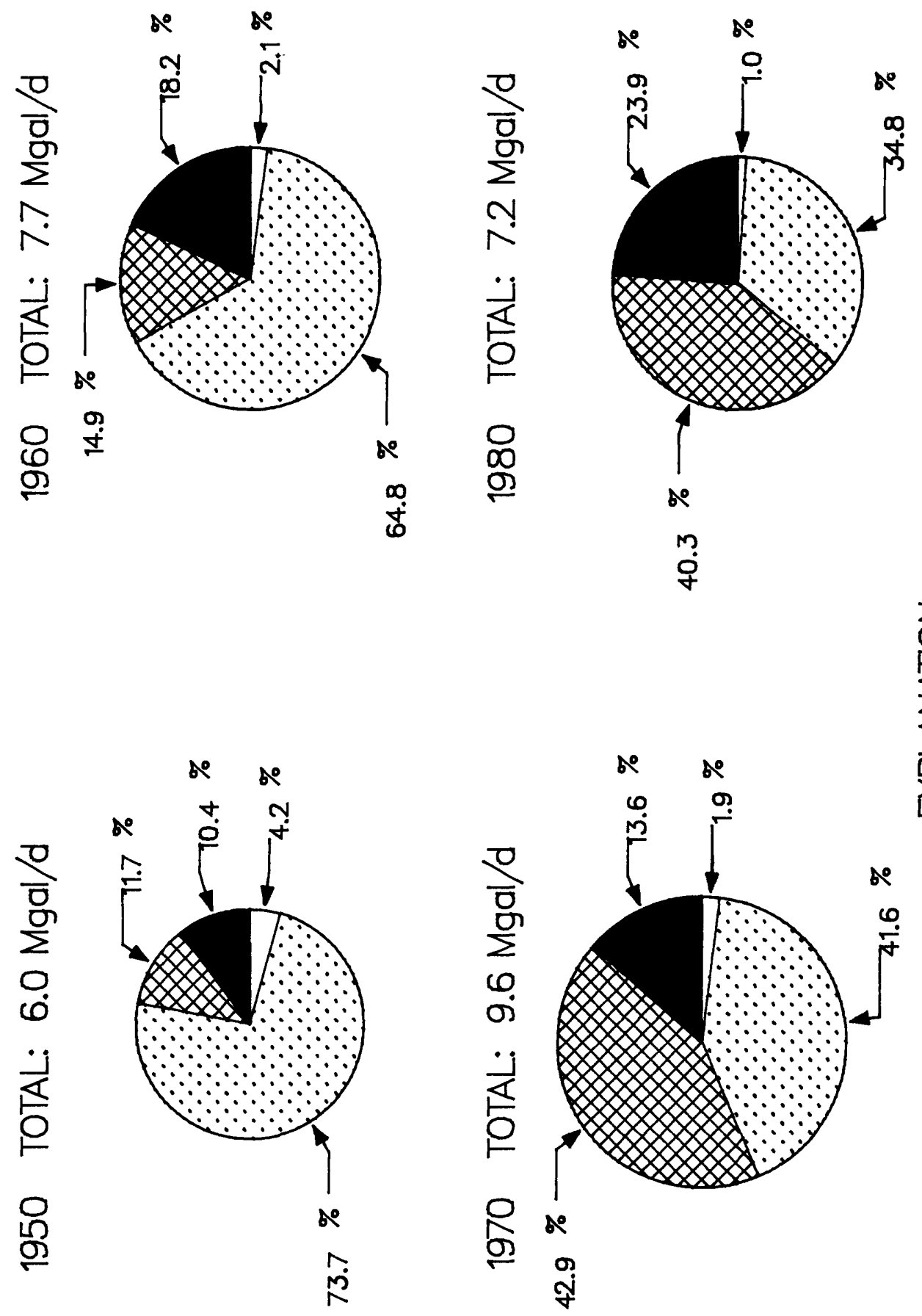

을
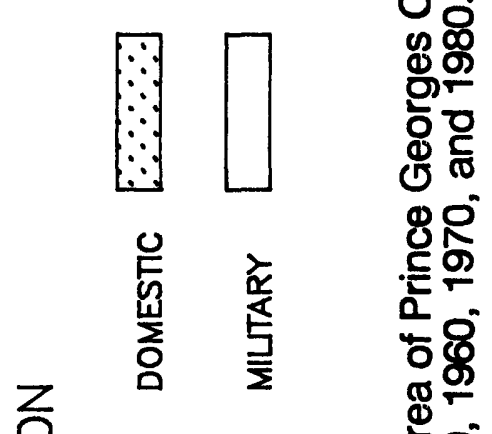

$z$
$\frac{1}{4}$
$\frac{1}{4}$
$\frac{1}{6}$

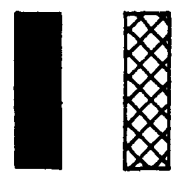

สิ

동은

믄

ब

\%

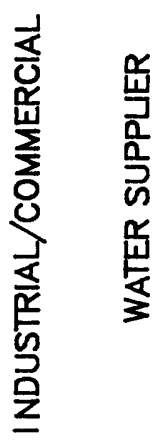

उั

일

당

동

$3 \%$

혼

0

응

동ํㅀ

ঠัঁ \$

ஸी

인 


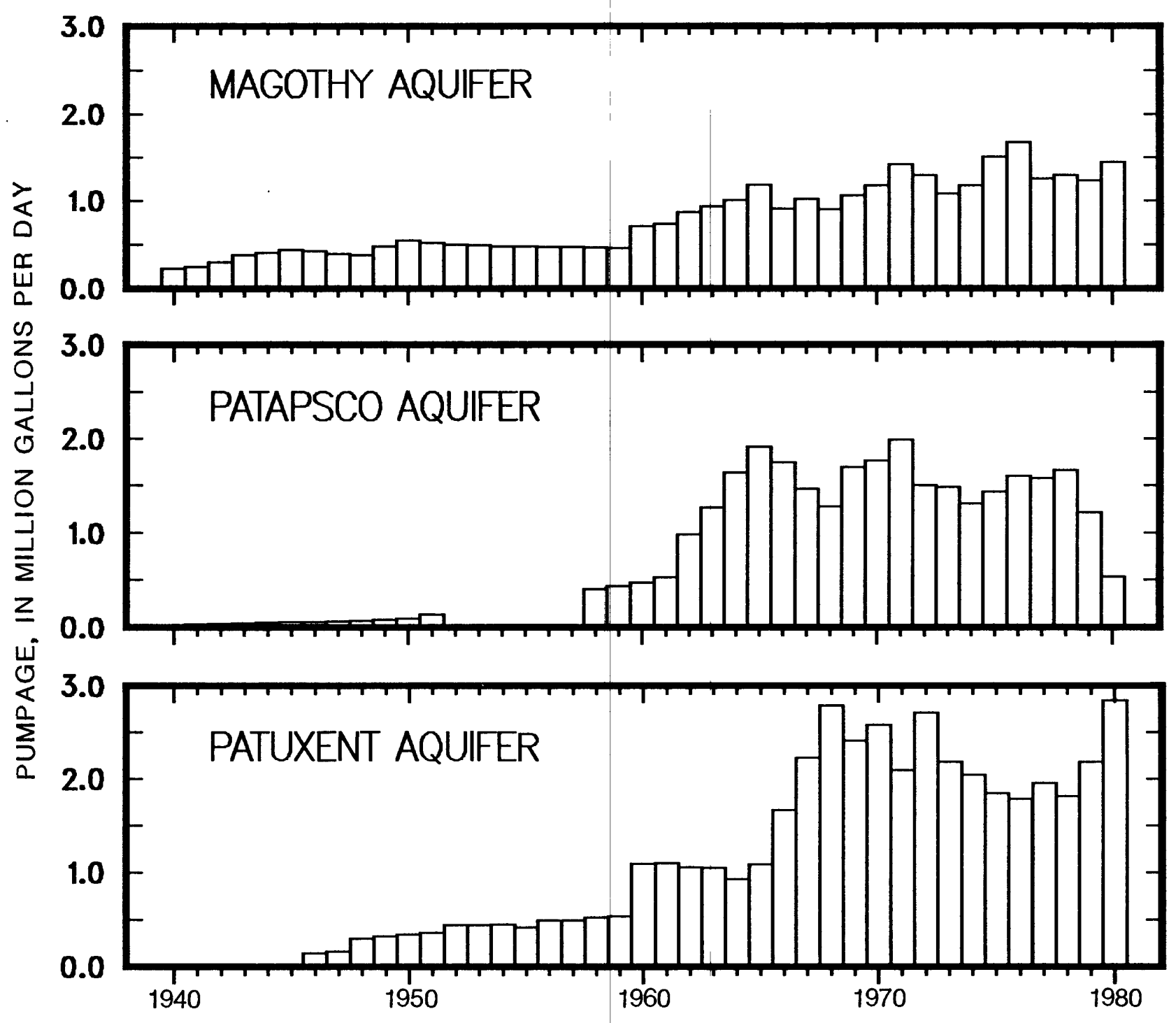

Figure 57.--Large ground-water withdrawals by aquifers in the Coastal Plain area of Prince Georges County from 1940 through 1980. 


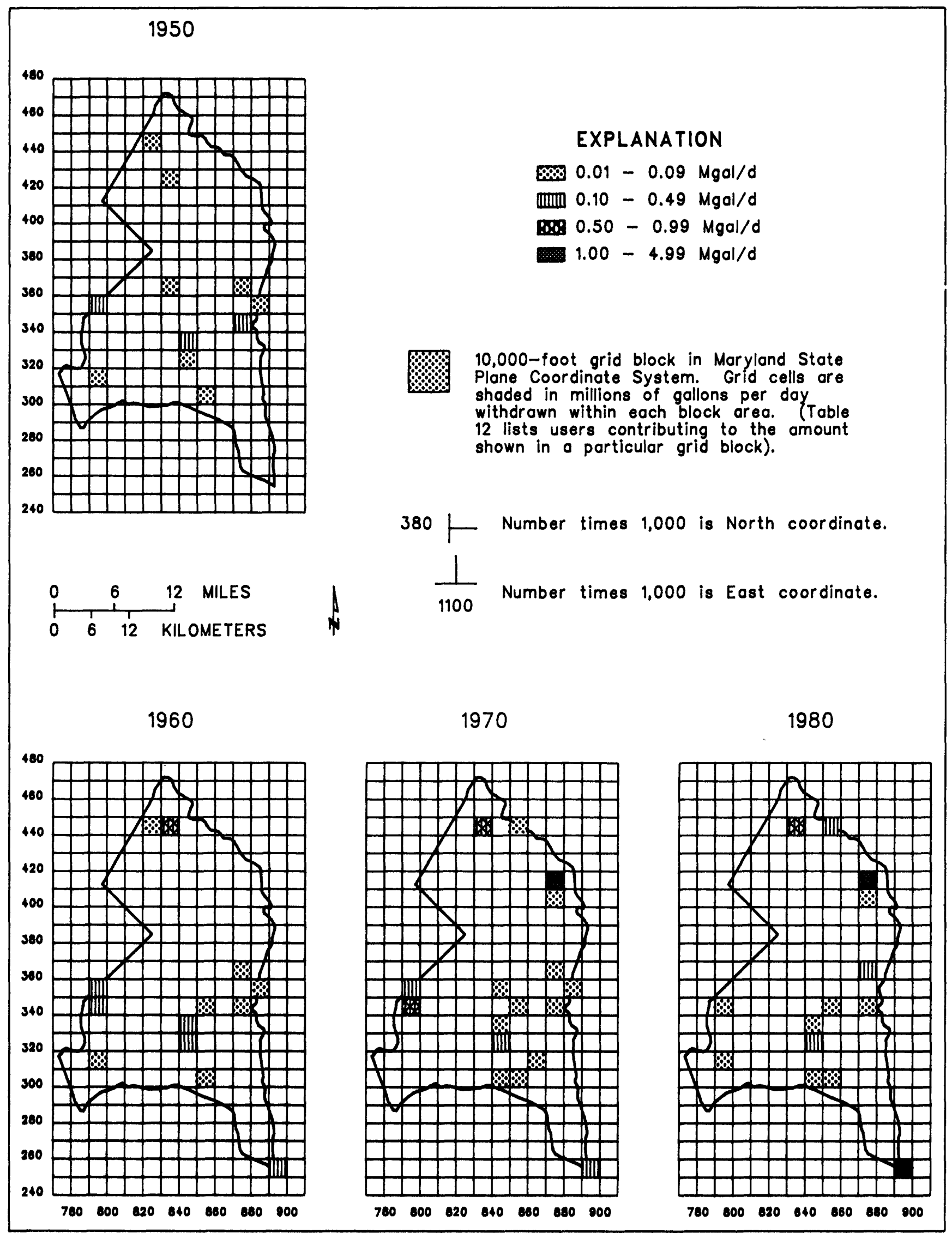

Figure 58.--Locations of large ground-water withdrawals in the Coastal Plain area of Prince Georges County for 1950, 1960, 1970, and 1980. 
Table 12.--Large ground-water users in the Coastal Flain area of Prince Georges County in 1950 , 1960, 1970, and 1980, summarized by the Maryland Grid Coordinate System

\begin{tabular}{|c|c|c|c|c|}
\hline Year & Grid block & User & $\begin{array}{l}\text { Pumpage } \\
\text { (Msal/d) }\end{array}$ & Aquifer \\
\hline 1950 & $\begin{array}{ll}\text { N300 } & \text { E850 } \\
\text { N310 } & \text { E790 } \\
& \\
\text { N320 } & E 840 \\
\text { N330 } & E 840 \\
\text { N340 } & E 870 \\
\text { N350 } & E 790 \\
\text { N350 } & \mathbf{E} 880 \\
\text { N360 } & E 830 \\
\text { N360 } & E 870 \\
\text { N420 } & \text { E830 } \\
\text { N440 } & \mathbf{E} 820\end{array}$ & $\begin{array}{l}\text { Cedarville Park, Incorporated } \\
\text { Fort Washington } \\
\text { do. } \\
\text { Boys' Village } \\
\text { U.S. Navy, Cheltenhem } \\
\text { Upper Mariboro, WssC } \\
\text { Forest Beights, WsSC } \\
\text { Willie G. Sauerwein } \\
\text { Morningside Village } \\
\text { Northeast Marlboro Water System } \\
\text { Greenbelt Consumer Service } \\
\text { Mineral Pigments Corporation }\end{array}$ & $\begin{array}{l}0.05 \\
.01 \\
.01 \\
.03 \\
.32 \\
.12 \\
.19 \\
.01 \\
.08 \\
.01 \\
.10 \\
.04\end{array}$ & $\begin{array}{l}\text { Magothy } \\
\text { Patuxent } \\
\text { Patapsco } \\
\text { Magothy } \\
\text { Magothy } \\
\text { Magothy } \\
\text { Patuxent } \\
\text { Magothy } \\
\text { Patapsco } \\
\text { Magothy } \\
\text { Patuxent } \\
\text { Patuxent }\end{array}$ \\
\hline 1960 & 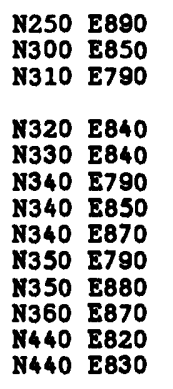 & $\begin{array}{l}\text { PEPCo, Chalk Point } \\
\text { Cedarville Park, Inc. } \\
\text { Fort Washington } \\
\text { do. } \\
\text { Boys' Village } \\
\text { U.s. Navy, Cheltenhem } \\
\text { Fort Foote, Wssc } \\
\text { Safeway Stores, Inc. } \\
\text { Upper Marlboro, WssC } \\
\text { Forest Beights, Wssc } \\
\text { Willie G. Sauerwein } \\
\text { Northeast Marlboro water systcm } \\
\text { Mineral Pigments Corporation } \\
\text { U.s. Dept. of Asriculture, Beltsville }\end{array}$ & $\begin{array}{l}0.24 \\
.06 \\
.03 \\
.02 \\
.14 \\
.18 \\
.45 \\
.01 \\
.06 \\
.46 \\
.01 \\
.01 \\
.07 \\
.53\end{array}$ & $\begin{array}{l}\text { Magothy } \\
\text { Magothy } \\
\text { Patuxent } \\
\text { Patapsco } \\
\text { Magothy } \\
\text { Magothy } \\
\text { Patapsco } \\
\text { Magothy } \\
\text { Magothy } \\
\text { Patuxent } \\
\text { Magothy } \\
\text { Magothy } \\
\text { Patuxent } \\
\text { Patuxent }\end{array}$ \\
\hline 1970 & $\begin{array}{ll}\text { N250 } & \mathbf{E} 890 \\
\text { N300 } & \mathbf{E} 840 \\
\text { N300 } & \mathbf{E} 850 \\
\text { N310 } & \mathbf{E 8 6 0} \\
\text { N320 } & \mathbf{E} 840 \\
\text { N330 } & \mathbf{E} 840 \\
\text { N340 } & \mathbf{E 7 9 0} \\
\text { N340 } & \mathbf{E 8 5 0} \\
\text { N340 } & \mathbf{E} 870 \\
\text { N350 } & \mathbf{E 7 9 0} \\
\text { N350 } & \mathbf{E} 840 \\
\text { N350 } & \mathbf{E 8 8 0} \\
\text { N360 } & \mathbf{E 8 7 0} \\
\text { N400 } & \mathbf{E 8 7 0} \\
\text { N410 } & \mathbf{E 8 7 0} \\
& \\
\text { N440 } & \mathbf{E} 830 \\
\text { N440 } & \mathbf{E} 850\end{array}$ & $\begin{array}{l}\text { PEPCo, Chalk Point } \\
\text { U.S. Neval Research Ldboratory, } \\
\text { Brandywine } \\
\text { Cedarville Park, Inc. } \\
\text { BFW Fabrication Company } \\
\text { U.S. Alr Force Country Club } \\
\text { Boys Village } \\
\text { U.S. Navy, Cheltenhem } \\
\text { Fort Foote, WsSC } \\
\text { Safeway Stores, Inc, } \\
\text { Upper Marlboro, WssC } \\
\text { Forest Beights, WssC } \\
\text { Lone Star Industries, Inc. } \\
\text { Willie G. Sauerwein } \\
\text { Northeast Marlboro water system } \\
\text { First Maryland Utilities, Inc. } \\
\text { Simpson Land Company, Inc. } \\
\text { Bowie, City of } \\
\text { do. } \\
\text { U.S. Dept. of Agriculture, Belteville } \\
\text { Patuxent Wildlife Res erch Center }\end{array}$ & $\begin{array}{r}0.48 \\
.03 \\
.06 \\
.01 \\
.07 \\
.11 \\
.08 \\
.67 \\
.01 \\
.05 \\
.47 \\
.02 \\
.01 \\
.01 \\
.06 \\
.01 \\
1.42 \\
.99 \\
.27 \\
.70 \\
.07\end{array}$ & $\begin{array}{l}\text { Magothy } \\
\text { Patapsco } \\
\text { Magothy } \\
\text { Magothy } \\
\text { Potomac Group } \\
\text { Magothy } \\
\text { Magothy } \\
\text { Patapsco } \\
\text { Magothy } \\
\text { Magothy } \\
\text { Patuxent } \\
\text { Magothy } \\
\text { Magothy } \\
\text { Magothy } \\
\text { Magothy } \\
\text { Magothy } \\
\text { Patuxent } \\
\text { Patapsco } \\
\text { Magothy } \\
\text { Patuxent } \\
\text { Patapsco }\end{array}$ \\
\hline 1980 & 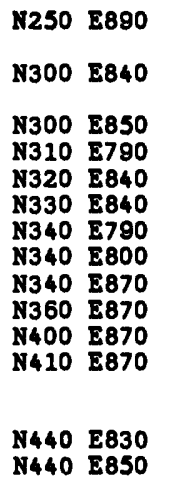 & $\begin{array}{l}\text { PEPCo, Chalk Point } \\
\text { do. } \\
\text { U.s. Naval Research Laboratory, } \\
\text { at Brandywine } \\
\text { Cedarville Park, Inc. } \\
\text { Calvert Manor Corporation } \\
\text { Boys' Village } \\
\text { U.S. Navy, Cheltenhem } \\
\text { Potomac Vista Corporation } \\
\text { Cedar Ridge Compeny } \\
\text { Upper Marlboro, Wssc } \\
\text { First Maryland Utilities, Inc. } \\
\text { Simpson Land Company, Inc. } \\
\text { Bowie, City of } \\
\text { do. } \\
\text { U.s. Dept. of Agriculture, Beltsville } \\
\text { Patuxent Wildlife Research Center }\end{array}$ & $\begin{array}{r}0.30 \\
.78 \\
.01 \\
.04 \\
.02 \\
.11 \\
.06 \\
.02 \\
.02 \\
.02 \\
.18 \\
.01 \\
2.08 \\
.16 \\
.24 \\
.61 \\
.16\end{array}$ & $\begin{array}{l}\text { Patapsco } \\
\text { Magothy } \\
\text { Patapsco } \\
\text { Magothy } \\
\text { Patapsco } \\
\text { Magothy } \\
\text { Magothy } \\
\text { Patapsco } \\
\text { Patapsco } \\
\text { Magothy } \\
\text { Magothy } \\
\text { Magothy } \\
\text { Patuxent } \\
\text { Patapsco } \\
\text { Magothy } \\
\text { Patuxent } \\
\text { Patuxent }\end{array}$ \\
\hline
\end{tabular}


1950

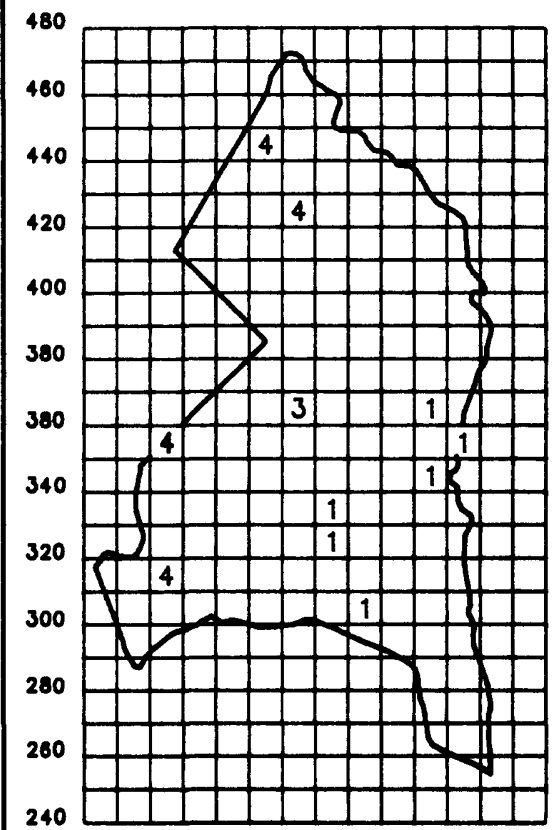

\begin{tabular}{lllll|}
0 & & 6 & 12 & MILES \\
0 & 1 & 12 & 12 & KILOMETERS
\end{tabular}

\section{EXPLANATION}

$1=$ Mogothy

2 = Potomac Group

$3=$ Patapsco

4 = Patuxent

5 = Magothy \& Patapsco

6 = Patapsco \& Patuxent

7 = Magothy, Patapsco \&

Patuxent

10,000-foot grid block in Maryland State

1 Plane Coordinate System. Numbers are codes for the aquifer from which water is withdrawn within a particular grid block.
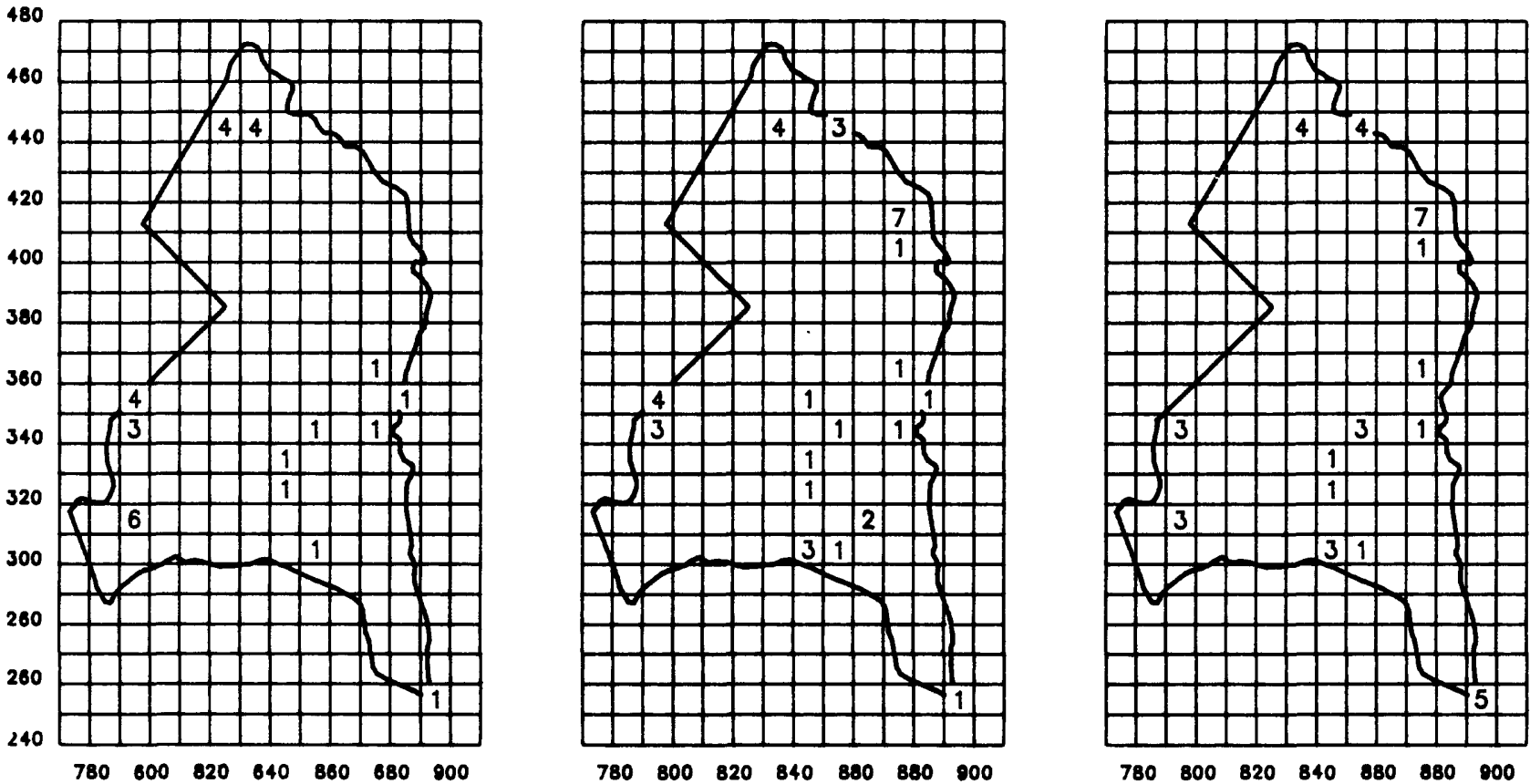

Figure 59.--Locations of large ground-water withdrawals by aquifers in the Coastal Plain area of Prince Georges County for 1950, 1960, 1970, and 1980. 


\section{QUEEN ANNES COUNTY}

Ground-water use in Queen Annes County from 1950 through 1980 is shown in figure 60. In 1950, the amount of ground water withdrawn was approximately $1.2 \mathrm{Mgal} / \mathrm{d}$ compared to withdrawals of $4.0 \mathrm{Mgal} / \mathrm{d}$ in 1980. This represents an increase of 233 percent for the three decades.

Since 1950, ground-water use in the county has increased in all categories. The largest withdrawals were for domestic use. In 1950 , about $1.0 \mathrm{Mgal} / \mathrm{d}$ was withdrawn compared to nearly $1.77 \mathrm{Mgal} / \mathrm{d}$ in 1980 . Withdrawals by water suppliers remained fairly constant for most of the 30-year period (approximately 0.3 $\mathrm{Mgal} / \mathrm{d}$ ), with an increase to about $0.4 \mathrm{Mgal} / \mathrm{d}$ in 1980. Industrial/commercial water use increased from about $0.06 \mathrm{Mgal} / \mathrm{d}$ in 1950 to about $0.5 \mathrm{Mgal} / \mathrm{d}$ in 1980 .

Water withdrawn for irrigation was the second greatest use, increasing from less than $0.01 \mathrm{Mgal} / \mathrm{d}$ in 1950 to about $1.5 \mathrm{Mgal} / \mathrm{d}$ in 1980 . Although irrigation was an important water use in the county, there were no precise measurements of the amounts of water withdrawn by individual irrigators. Methods of collecting and reporting these data have improved since the early 1950's. The most reliable data are from 1970 to 1980. See appendix for ground-water withdrawal data for each large user: User's name, appropriation permit number, source aquifer, location on the Maryland Grid Coordinate System, average pumpage, and year pumping began.

The percentages of the total amount of ground water withdrawn for domestic, water supplier, industrial/commercial, and irrigation uses are shown in figure 61. Domestic use comprised a significant portion of the total pumpage for 1950,1960 , and 1970 . The figure also shows that the percentage of water used for irrigation has increased considerably from 4 percent in 1950 to 37 percent in 1980.

\section{Major Aquifers}

Many domestic withdrawals in Queen Annes County were from shallow wells (from about 15 to 45 $\mathrm{ft}$ deep) tapping the surficial aquifer. Deeper aquifers including the Aquia, Severn, and Magothy were more widely used by large users. Large user withdrawals by aquifer from 1950 through 1980 are shown in figure 62.
From 1900 through 1980, the Aquia Formation was a major source for low- yield water needs for Kent Island and several areas on the mainland of the county. During the 1940's, large users began withdrawing water from the Aquia aquifer. Since that time, it has been the most important source of water for large users in the county (see appendix). In 1950, about $0.05 \mathrm{Mgal} / \mathrm{d}$ were withdrawn from the aquifer compared to nearly 0.3 $\mathrm{Mgal} / \mathrm{d}$ in 1980.

The greatest withdrawals were from the Severn aquifer. It has served as a source of water for the town of Centreville since about 1900 (see appendix). Pumpage steadily increased from about $0.2 \mathrm{Mgal} / \mathrm{d}$ in 1900 to $0.3 \mathrm{Mgal} / \mathrm{d}$ in 1980 . As of 1980 , the Centreville water supply was the only large user withdrawing water from the Severn aquifer.

The use of the Magothy Formation as a source of water for large users was limited to the U.S. Army Corps of Engineers' Chesapeake Bay Model facility located at Matapeake on Kent Island. Pumping from the aquifer began in 1976 and increased from 0.05 to $0.07 \mathrm{Mgal} / \mathrm{d}$ in 1979 . However, withdrawals declined by 1980 to $0.04 \mathrm{Mgal} / \mathrm{d}$.

\section{Locations of Large Ground-Water Withdrawals}

The locations of withdrawals by large users in Queen Annes County for 1950, 1960, 1970, and 1980 are shown in figure 63. Table 13 presents water- use data for the large users located within particular grid blocks for the year indicated on the map. In 1950, the areas of greatest pumpage were located at Centreville and in the south-central part of the county. By 1980 , several more large users were withdrawing ground water, mostly in the western and southern parts of the county.

The locations of withdrawals from individual aquifers supplying the large users in Queen Annes County (described in table 13 and fig. 63) are shown in figure 64. The Aquia and Severn aquifers were the principal sources of ground water for large users for the years shown. Withdrawals from both aquifers were located primarily in the central and south-central part of the county. The Magothy aquifer was not used as a source of water until 1976 (see appendix). It was the deepest aquifer used in 1980, and the only withdrawals were from wells located at Matapeake. 


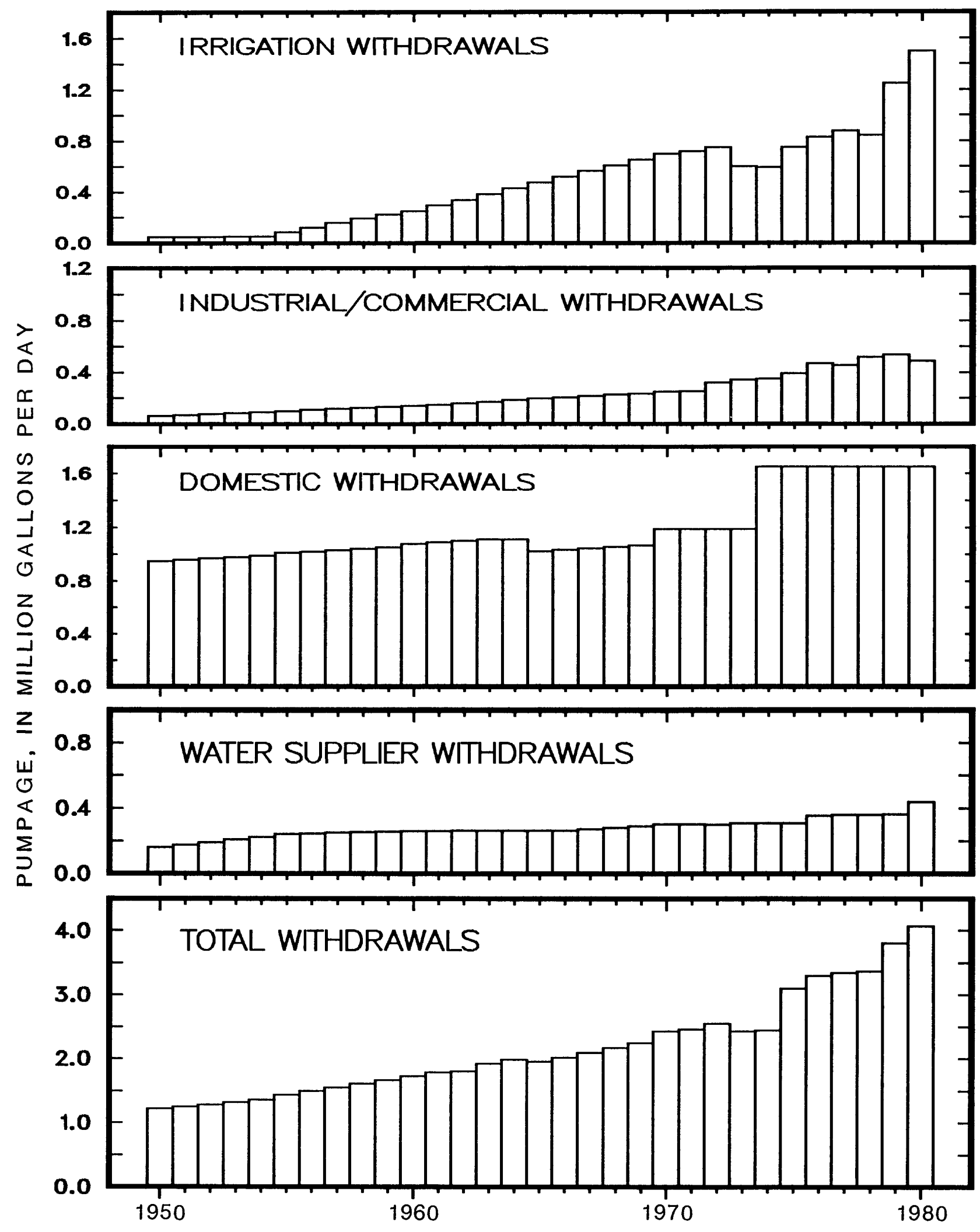

Figure 60.--Ground-water withdrawals by use in Queen Annes County from 1950 through 1980. 


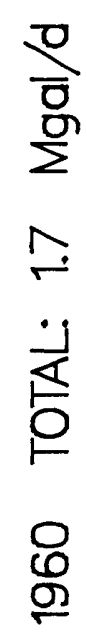

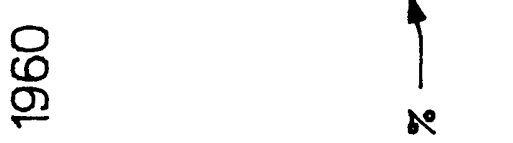

$\frac{\text { po }}{\frac{0}{2}}$

ำ

定

웅
ชู่
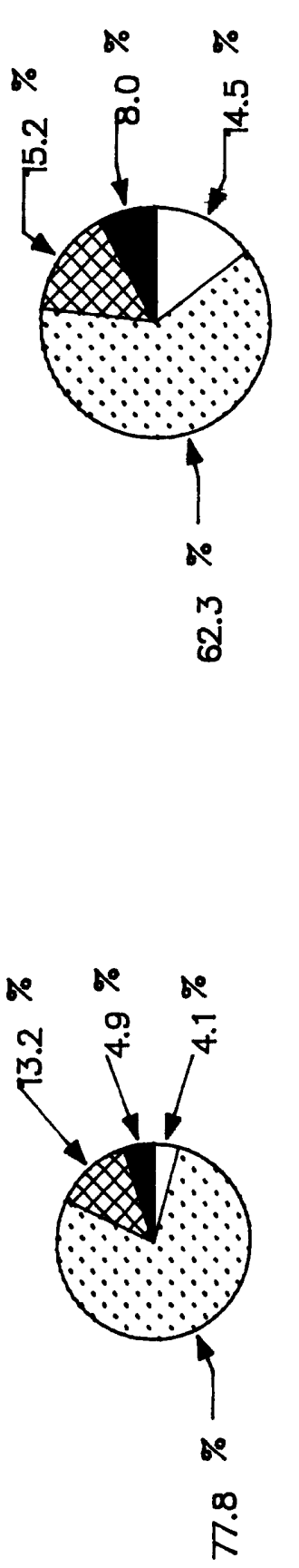

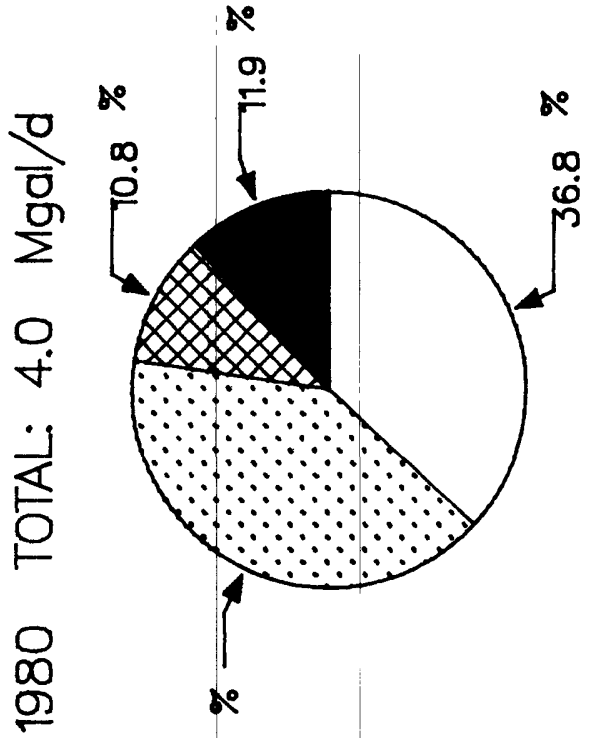

เุ

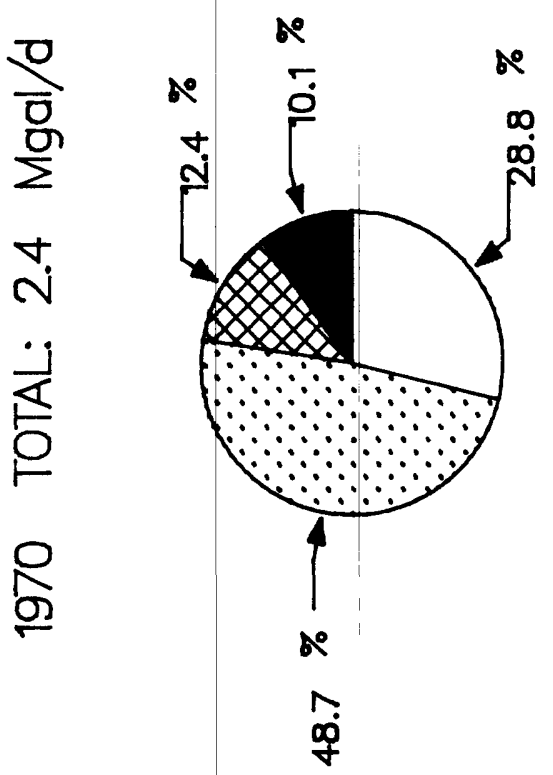

ธ

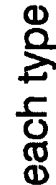

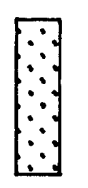

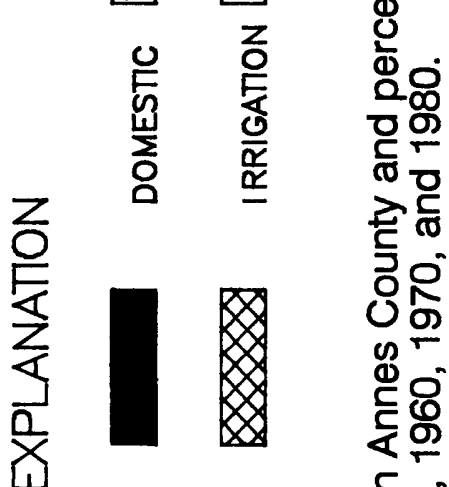

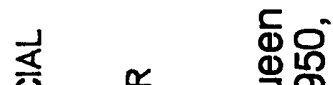

造 㟒宁

帟苛

告

总

离 

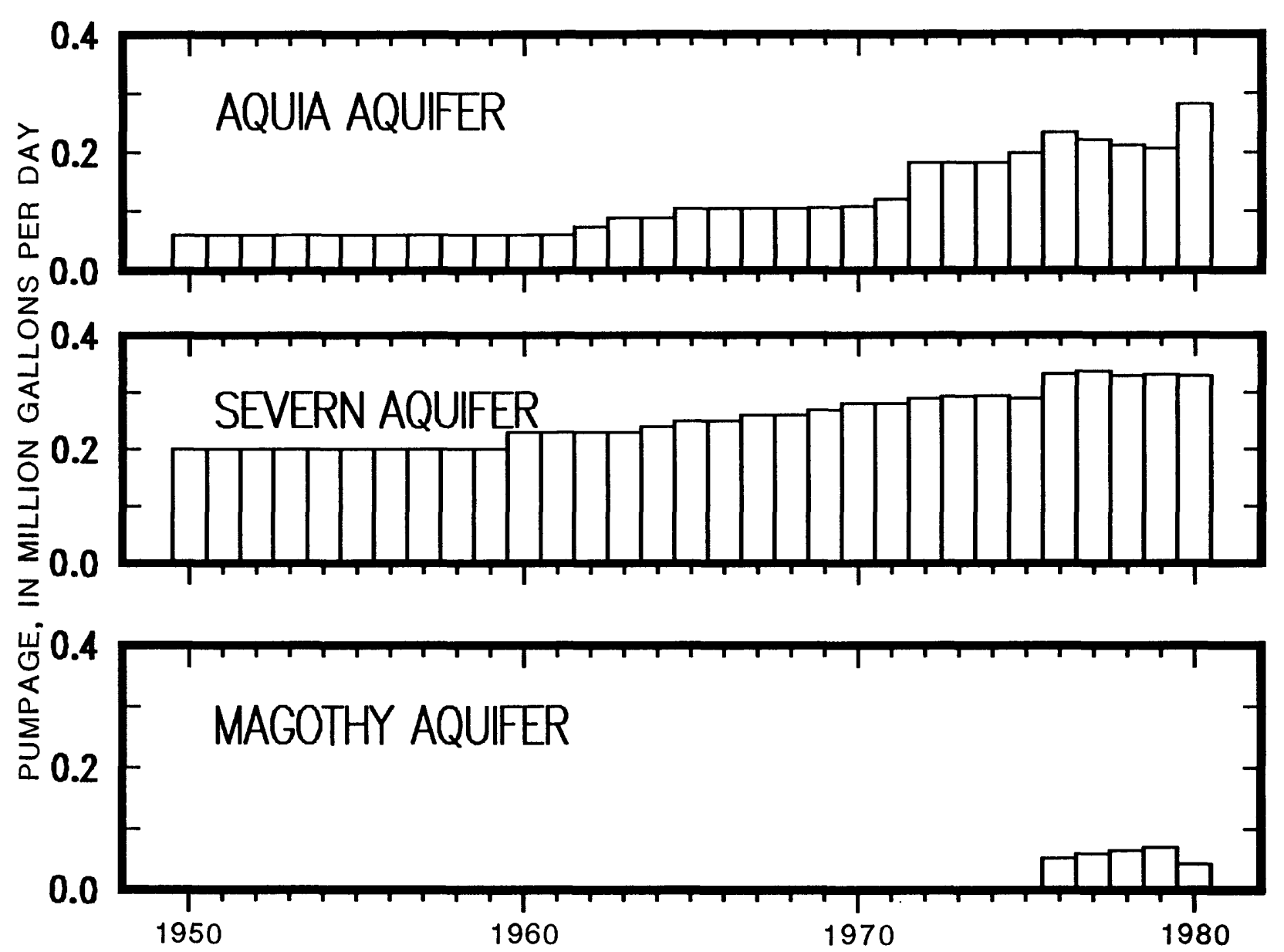

Figure 62.--Large ground-water withdrawals by aquifers in Queen Annes County from 1950 through 1980. 


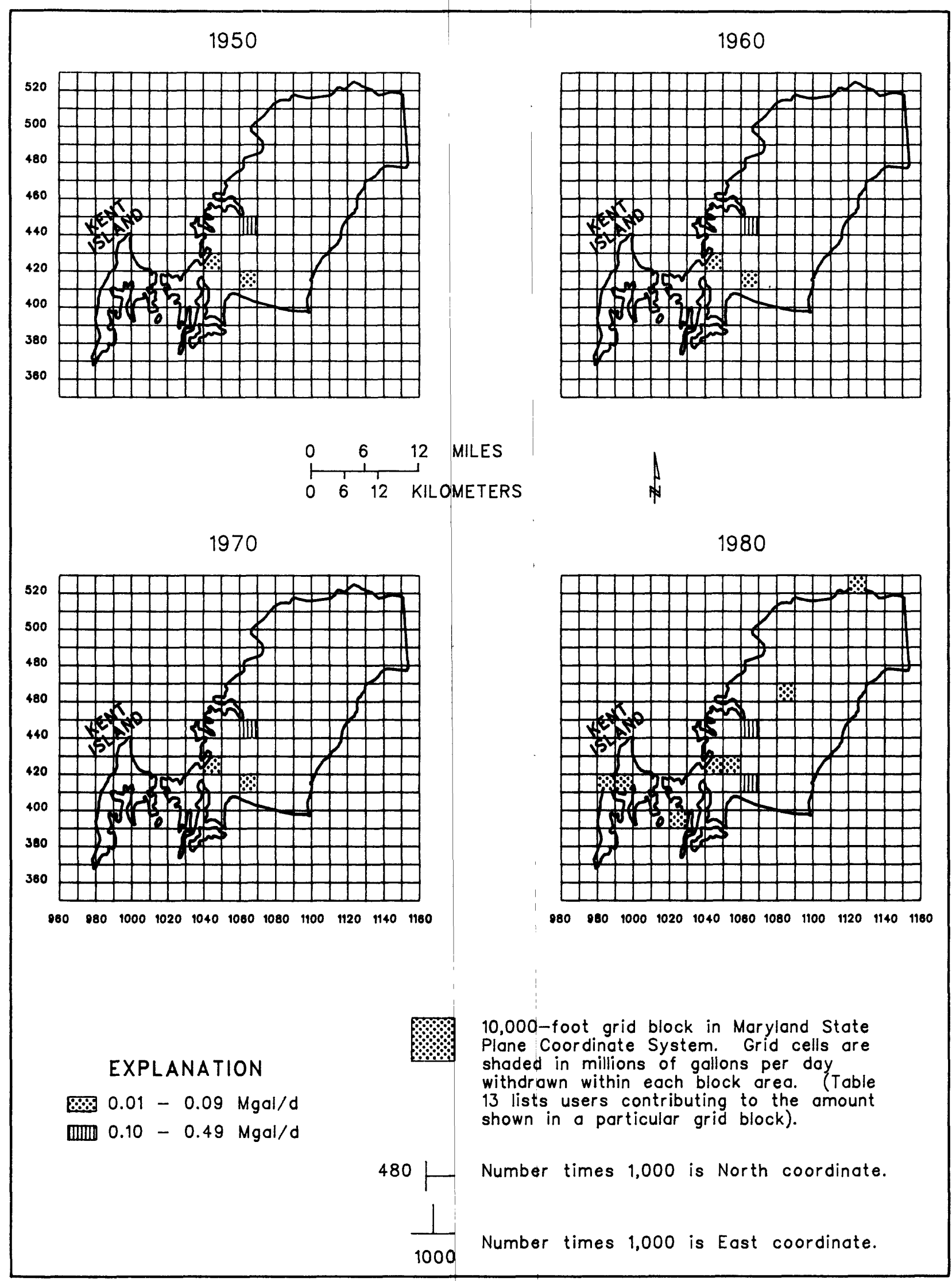

Figure 63.--Locations of large ground-water withdrawals in Queen Annes County for 1950, 1960, 1970, and 1980. 
Table 13.--Large ground-water users in Queen Ames County in 1950, 1960, 1970, and 1880, sumarized by the Marylend Orid Coordinate Syatem

\begin{tabular}{|c|c|c|c|c|}
\hline Year & Gr1d blook & User & $\begin{array}{l}\text { Pumpase } \\
\text { (Meal/d) }\end{array}$ & Aquifer \\
\hline 1950 & $\begin{array}{l}\$ 410 \geq 1060 \\
\$ 420 \geq 1040 \\
\$ 440 \mathrm{E} 1060\end{array}$ & $\begin{array}{l}\text { s.E.W. Friel Cannery, } \\
\text { (Whe Mille Plent) } \\
\text { s.E.W. Friel Cannery, } \\
\text { (Quoenstown Plent) } \\
\text { Contreville, Town of }\end{array}$ & $\begin{array}{r}0.04 \\
.02 \\
.20\end{array}$ & $\begin{array}{l}\text { Aquia } \\
\text { Aquia } \\
\text { Sovorn }\end{array}$ \\
\hline 1960 & $\begin{array}{l}\$ 410 \mathrm{E1060} \\
\$ 420 \mathrm{E1040} \\
\$ 440 \mathrm{E1060}\end{array}$ & 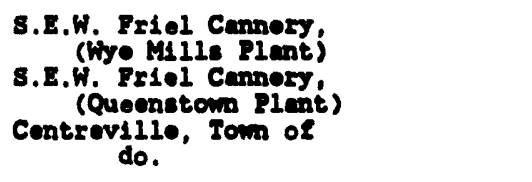 & $\begin{array}{r}0.03 \\
.02 \\
.13 \\
.09\end{array}$ & $\begin{array}{l}\text { Aquia } \\
\text { Aquia } \\
\text { Severn } \\
\text { Aquia }\end{array}$ \\
\hline 1970 & $\begin{array}{l}\$ 410 \mathbf{8 1 0 6 0} \\
\$ 420 \mathrm{\Sigma} 1040 \\
\$ 440 \mathrm{E}\end{array}$ & $\begin{array}{l}\text { s.z.W. Friel Cannery, } \\
\text { (Wye Milis Plant) } \\
\text { s.z.W. Friel Camnery, } \\
\text { (Queonstown Plant) } \\
\text { Controville, Town of } \\
\text { do. }\end{array}$ & $\begin{array}{r}0.08 \\
.02 \\
.20 \\
.12\end{array}$ & $\begin{array}{l}\text { Aquia } \\
\text { Aquia } \\
\text { Severn } \\
\text { Aquia }\end{array}$ \\
\hline 1980 & 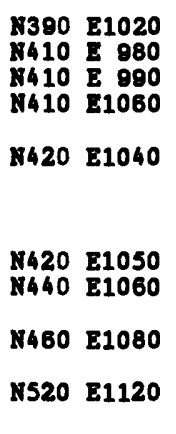 & 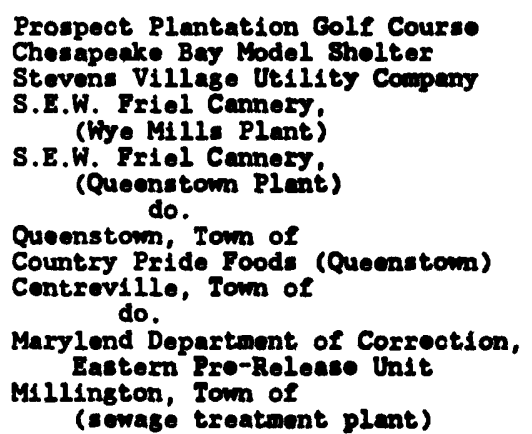 & $\begin{array}{l}0.02 \\
.04 \\
.03 \\
.11 \\
.03 \\
.02 \\
.04 \\
.02 \\
.20 \\
.13 \\
.02 \\
.02\end{array}$ & $\begin{array}{l}\text { Aquia } \\
\text { Magothy } \\
\text { Aquia } \\
\text { Aquia } \\
\text { Aquia } \\
\text { Cheswold } \\
\text { Aquila } \\
\text { Aquia } \\
\text { Severn } \\
\text { Aquila } \\
\text { Aquia } \\
\text { Aquia }\end{array}$ \\
\hline
\end{tabular}




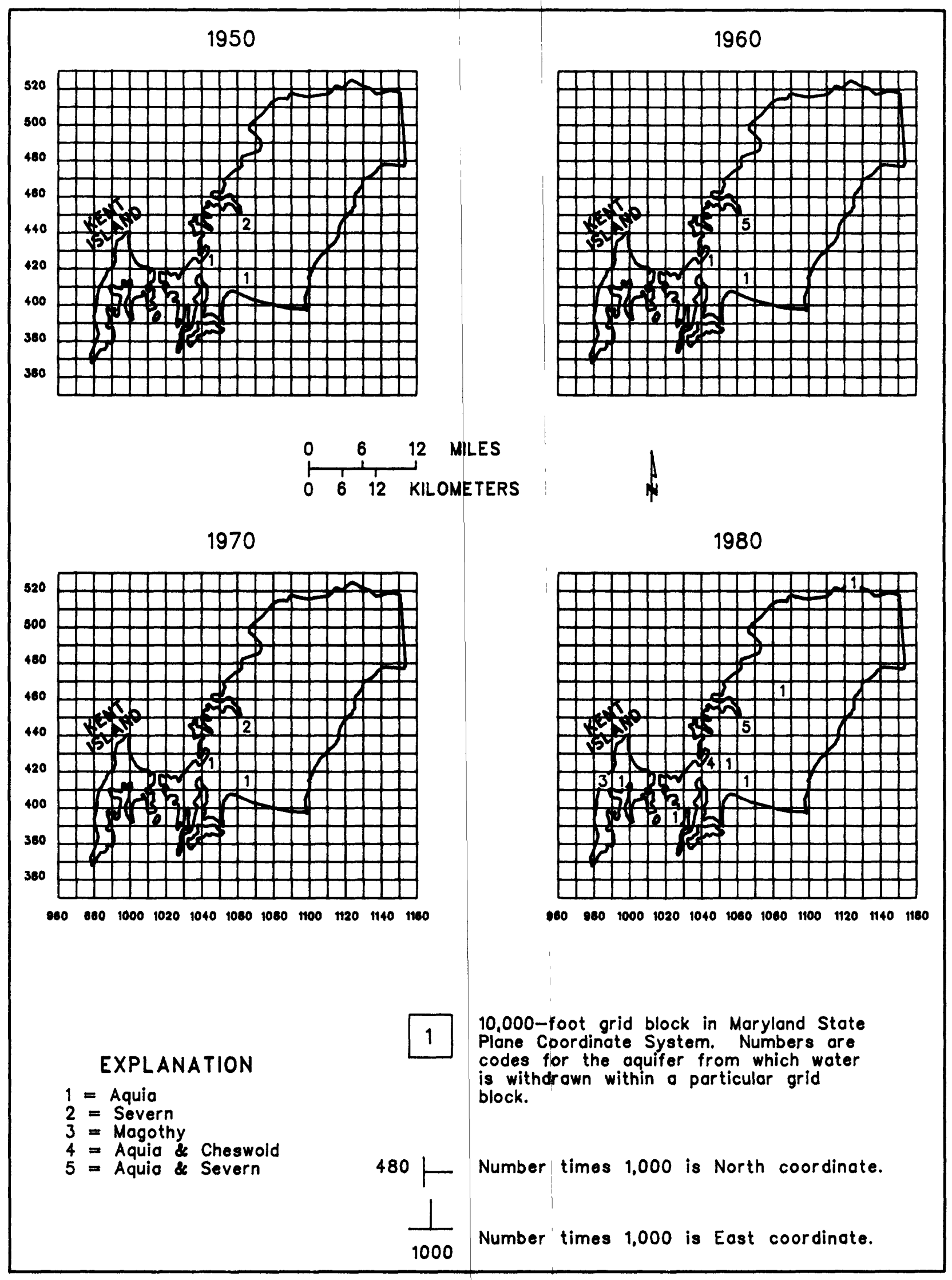

Figure 64.--Locations of large ground-water withdrawals by aquifers in Queen Annes County for 1950, 1960, 1970, and 1980. 


\section{ST. MARYS COUNTY}

Ground-water use in St. Marys County from 1950 through 1980 is shown in figure 65. In 1950, the amount of ground water withdrawn was approximately 3.5 Mgal/d compared to withdrawals of about $5.6 \mathrm{Mgal} / \mathrm{d}$ in 1980. This represents an increase of 60 percent for the three decades.

Since 1950, water use in St. Marys County increased in all categories except military use. The greatest amounts were withdrawn for domestic use, which increased from about $1.7 \mathrm{Mgal} / \mathrm{d}$ in 1950 to $2.8 \mathrm{Mgal} / \mathrm{d}$ in 1980. Pumpage by military facilities was about 1.5 $\mathrm{Mgal} / \mathrm{d}$ in 1950 . Withdrawals gradually declined over the next 30 years to $0.9 \mathrm{Mgal} / \mathrm{d}$ in 1980 . Water suppliers used approximately $0.3 \mathrm{Mgal} / \mathrm{d}$ of ground water in 1950 . By 1980 , these withdrawals had increased to $1.8 \mathrm{Mgal} / \mathrm{d}$. Industrial/commercial use increased from about 0.01 $\mathrm{Mgal} / \mathrm{d}$ in 1950 to just more than $0.1 \mathrm{Mgal} / \mathrm{d}$ in 1980 . See appendix for ground-water withdrawal data for each large user: User's name, appropriation permit number, source aquifer, location on the Maryland Grid Coordinate System, average daily pumpage, and year pumping began.

The percentages of the total amount of ground water withdrawn for domestic, military, water supplier, and industrial/commercial uses are shown in figure 66. Domestic use comprised a significant portion of the total punipage for all the years shown. Military use accounted for 42 percent of total pumpage in 1950, but by 1980 this percentage had dropped to 16 percent. Industrial use comprised only a very small percentage for the 4 years shown in figure 66 (no more than 2 percent).

\section{Major Aquifers}

Many domestic withdrawals in St. Marys County were from shallow wells (from about 15 to $45 \mathrm{ft}$ deep) tapping the surficial aquifer. Deeper aquifers including the Piney Point and Aquia were more widely used by large users. Large user withdrawals by aquifer from 1950 through 1980 are shown in figure 67.

Withdrawals from the Piney Point aquifer increased from about $0.2 \mathrm{Mgal} / \mathrm{d}$ in 1950 to $0.4 \mathrm{Mgal} / \mathrm{d}$ in 1980. Extensive use of the Aquia aquifer began in the 1940 's when the naval facility was built near Lexington Park. In 1950, approximately $1.7 \mathrm{Mgal} / \mathrm{d}$ was withdrawn from the Aquia. Its use increased over the next 30 years, and by 1980 more than $2.3 \mathrm{Mgal} / \mathrm{d}$ were being pumped.

\section{Locations of Large Ground-Water Withdrawals}

The locations of withdrawals by large users in St. Marys County for 1950,1960,1970, and 1980 are shown in figure 68 . Table 14 presents water-use data for the large users located within particular grid blocks for the year indicated on the map. From 1950 through 1970, the areal distribution of pumpage remained relatively the same, with increases in the number of sites in the Lexington Park area only. By 1980, large ground-water withdrawals were located throughout the county.

The locations of withdrawals from individual aquifers supplying the large users in St. Marys County (described in table 14 and fig. 68) are shown in figure 69. Use of the Piney Point aquifer centered mainly around Lexington Park for the 4 years shown. In 1950, the Aquia aquifer was used primarily in the Lexington Park area. This pattern of distribution showed little change on the map for 1960 . However, the maps for 1970 and 1980 show a wider area of use of the Aquia in the county. 


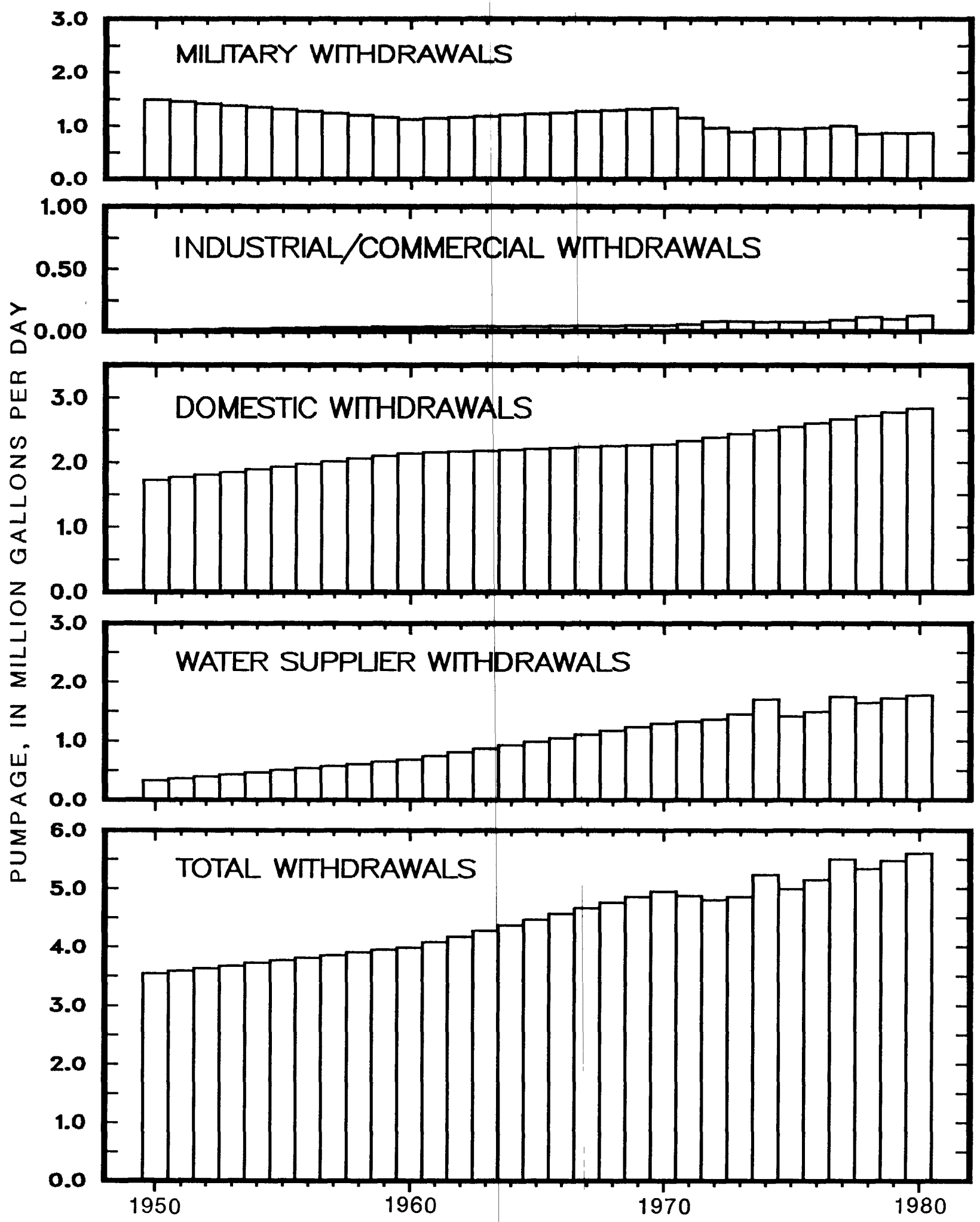

Figure 65.--Ground-water withdrawals by use in St. Marys County from 1950 through 1980. 

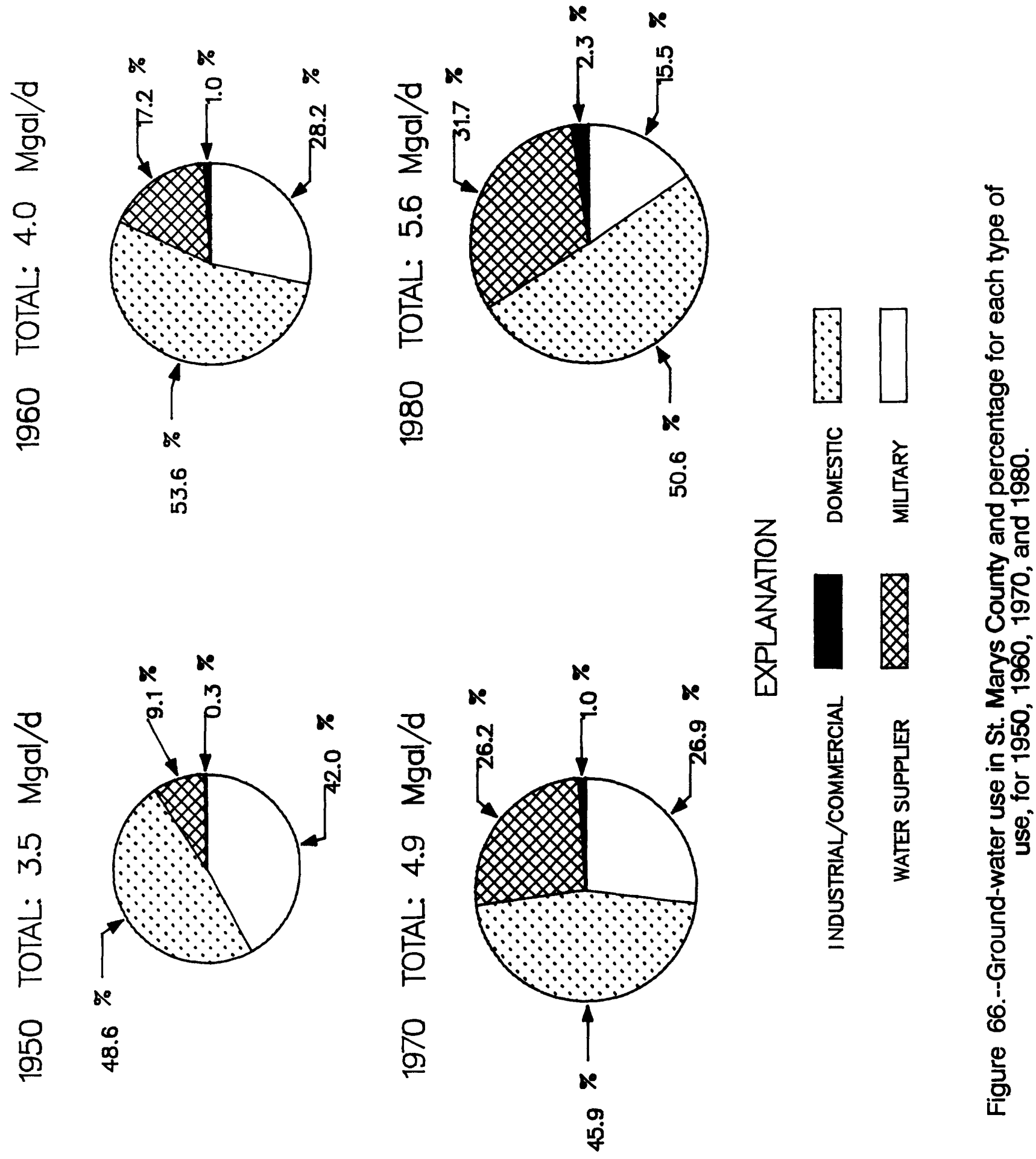


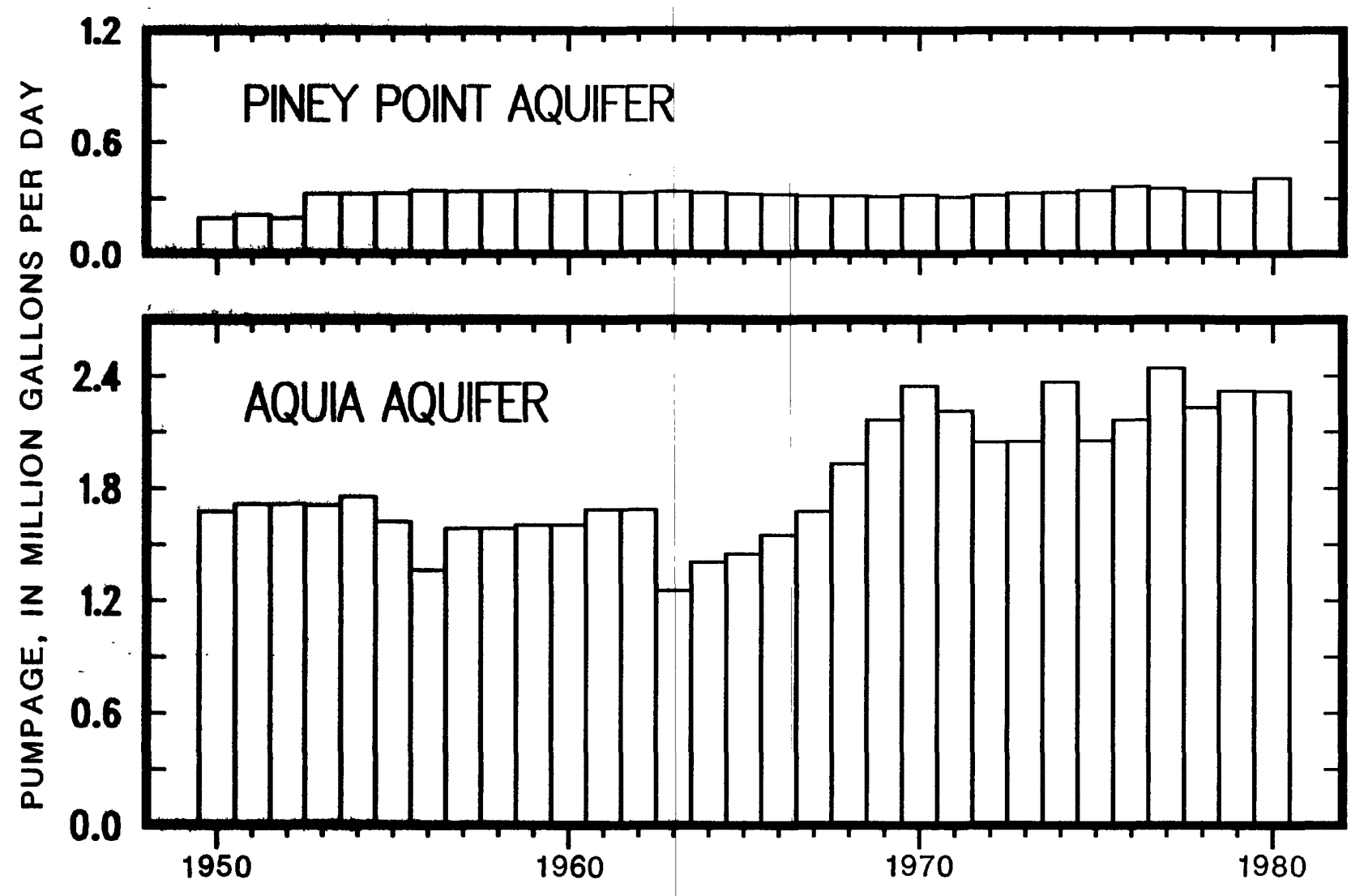

Figure 67.--Large ground-water withdrawals by aquifers in St. Marys County from 1950 through 1980. 


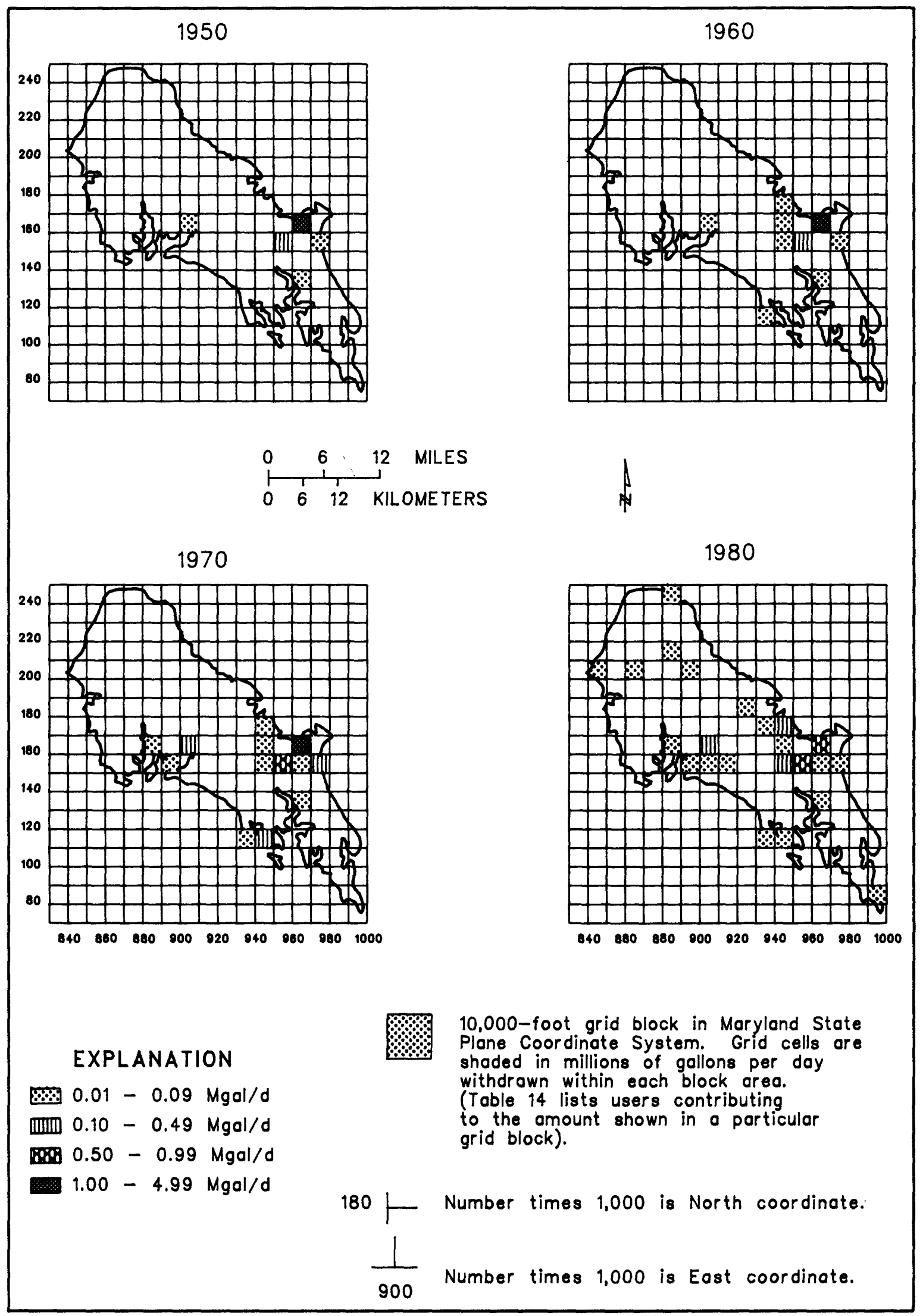

Figure 68.--Locations of large ground-water withdrawals in St. Marys County for 1950, 1960, 1970, and 1980. 
Table 14.--Large ground-water users in St. Marys County in 1950, 1960, 1970, and 1980, summarized by the Maryland Grid Coordinate System

\begin{tabular}{|c|c|c|c|c|}
\hline Year & Grid block & User & $\begin{array}{l}\text { Pumpage } \\
\text { (Mgal/d) }\end{array}$ & Aquifer \\
\hline 1950 & $\begin{array}{ll}\text { N130 } & E 960 \\
\text { N150 } & \text { E950 } \\
& \\
\text { N150 } & E 970 \\
& \\
\text { N160 } & E 900 \\
\text { N160 } & E 960\end{array}$ & $\begin{array}{c}\text { St. Marys College } \\
\text { Lexington Park, St. Marys } \\
\text { Metropolitan Commission } \\
\text { Patuxent Naval Air Station } \\
\text { do. } \\
\text { Leonardtown, Town of } \\
\text { Patuxent Naval Air Station } \\
\text { do. }\end{array}$ & $\begin{array}{r}0.02 \\
.23 \\
.03 \\
.03 \\
.03 \\
1.40 \\
.16\end{array}$ & $\begin{array}{l}\text { Aquia } \\
\text { Aquia } \\
\text { Piney Point } \\
\text { Aquia } \\
\text { Aquia } \\
\text { Aquia } \\
\text { Piney Point }\end{array}$ \\
\hline 1960 & $\begin{array}{ll}\text { N110 } & E 930 \\
\text { N130 } & E 960 \\
\text { N150 } & E 940 \\
\text { N150 } & E 950 \\
\text { N150 } & E 970 \\
\text { N160 } & E 900 \\
\text { N160 } & E 940 \\
\text { N160 } & E 960 \\
\text { N170 } & E 940\end{array}$ & $\begin{array}{c}\text { Steuart Petroleum Company } \\
\text { St. Marys College } \\
\text { James Hill Trailer Park } \\
\text { Lexintgon Park, St. Marys } \\
\text { Metropolitan Comission } \\
\text { Patuxent Naval Air Station } \\
\text { do. } \\
\text { Leonardtown, Town of } \\
\text { Mayjack, Incorporated } \\
\text { Patuxent Naval Air Station } \\
\text { do. } \\
\text { Town Creek Water Company }\end{array}$ & $\begin{array}{r}0.02 \\
.02 \\
.05 \\
.27 \\
.03 \\
.03 \\
.05 \\
.02 \\
1.20 \\
.15 \\
.08\end{array}$ & $\begin{array}{l}\text { Aquia } \\
\text { Aquia } \\
\text { Piney Point } \\
\text { Aquia } \\
\text { Piney Point } \\
\text { Aquia } \\
\text { Aquia } \\
\text { Piney Point } \\
\text { Aquia Point } \\
\text { Piney Point } \\
\text { Piney Point }\end{array}$ \\
\hline 1970 & $\begin{array}{ll}\text { N110 } & E 930 \\
\text { N110 } & E 940 \\
\text { N130 } & E 960 \\
\text { N150 } & E 890 \\
\text { N150 } & E 940 \\
\text { N150 } & E 950 \\
\text { N150 } & E 960 \\
\text { N150 } & E 970 \\
\text { N160 } & E 880 \\
\text { N160 } & E 900 \\
\text { N160 } & E 940 \\
\text { N160 } & E 960 \\
\text { N170 } & E 940\end{array}$ & $\begin{array}{l}\text { Steuart Petroleum Company } \\
\text { Lundeburs School of Seamanship } \\
\text { St. Marys College } \\
\text { Cherry Cove Water Company } \\
\text { James Hill Trailer Park } \\
\text { Greenview Knolls Water Company } \\
\text { Lexington Park, St. Marys } \\
\text { Metropolitan Comission } \\
\text { Cedar Cove, St. Marys } \\
\text { Metropolitan Commission } \\
\text { Patuxent Naval Air Station } \\
\text { St. Clements Shores Water Company } \\
\text { Leonardtown, Town of } \\
\text { Mayjack, Incorporated } \\
\text { Patuxent Naval Air Station } \\
\text { do. } \\
\text { Town Creek Water Company }\end{array}$ & $\begin{array}{r}0.02 \\
.10 \\
.05 \\
.05 \\
.05 \\
.03 \\
.68 \\
.05 \\
.05 \\
.05 \\
.02 \\
.16 \\
.02 \\
1.16 \\
.08 \\
.08\end{array}$ & $\begin{array}{l}\text { Aquia } \\
\text { Aquia } \\
\text { Aquia } \\
\text { Aquia } \\
\text { Piney Point } \\
\text { Piney Point } \\
\text { Aquia } \\
\text { Aquia } \\
\text { Piney Point } \\
\text { Aquia } \\
\text { Aquia } \\
\text { Aquia } \\
\text { Piney Point } \\
\text { Aquia } \\
\text { Piney Point } \\
\text { Piney Point }\end{array}$ \\
\hline 1980 & $\begin{array}{ll}\text { No80 } & E 990 \\
\text { N110 } & E 930 \\
\text { N110 } & E 940 \\
\text { N130 } & E 960 \\
\text { N150 } & E 890 \\
\text { N150 } & E 900 \\
\text { N150 } & E 910 \\
\text { N150 } & E 940 \\
& \\
\text { N150 } & E 950 \\
\text { N150 } & E 960 \\
\text { N150 } & E 970 \\
\text { N160 } & E 880 \\
\text { N160 } & E 900 \\
\text { N160 } & E 940 \\
& \\
\text { N160 } & E 960 \\
\text { N170 } & E 930 \\
\text { N170 } & E 940 \\
\text { N180 } & E 920 \\
\text { N200 } & E 840 \\
\text { N200 } & E 860 \\
\text { N200 } & E 890 \\
\text { N210 } & E 880 \\
\text { N240 } & E 880\end{array}$ & 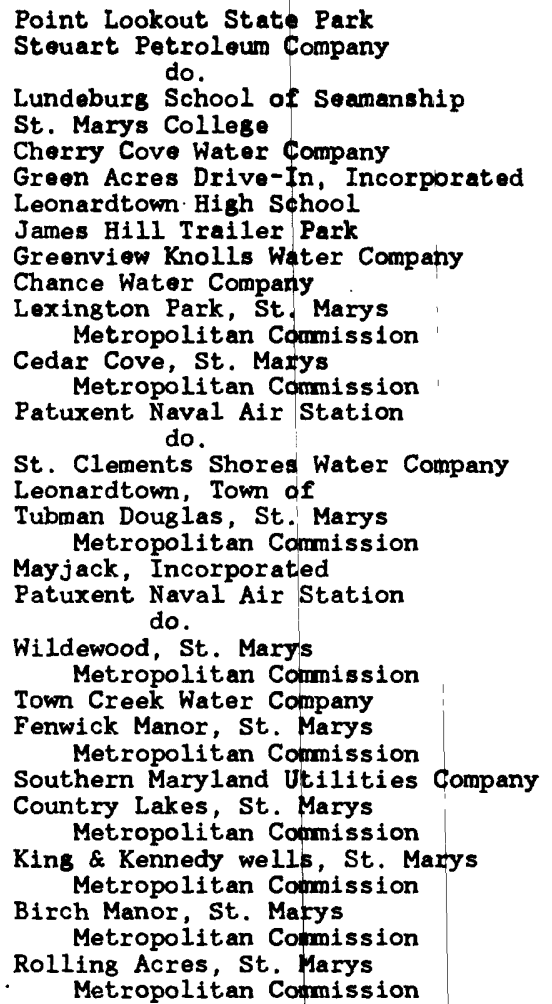 & $\begin{array}{l}0.01 \\
.02 \\
.02 \\
.08 \\
.06 \\
.06 \\
.03 \\
.01 \\
.04 \\
.07 \\
.01 \\
.69 \\
.05 \\
.02 \\
.02 \\
.03 \\
.31 \\
.04 \\
.04 \\
.77 \\
.06 \\
.03 \\
.15 \\
.02 \\
.01 \\
.03 \\
.02 \\
.02 \\
.02\end{array}$ & $\begin{array}{l}\text { Upper Cretaceous } \\
\text { Piney Point } \\
\text { Aquia } \\
\text { Aquia } \\
\text { Aquia } \\
\text { Aquia } \\
\text { Aquia } \\
\text { Aquia } \\
\text { Piney Point } \\
\text { Piney Point } \\
\text { Piney Point } \\
\text { Aquia } \\
\text { Aquia } \\
\text { Piney Point } \\
\text { Aquia } \\
\text { Aquia } \\
\text { Aquia } \\
\text { Aquia } \\
\text { Piney Point } \\
\text { Aquia } \\
\text { Piney Point } \\
\text { Aquia } \\
\text { Piney Point } \\
\text { Aquia } \\
\text { Patapsco } \\
\text { Aquia } \\
\text { Aquia } \\
\text { Aquia } \\
\text { Aquia }\end{array}$ \\
\hline
\end{tabular}




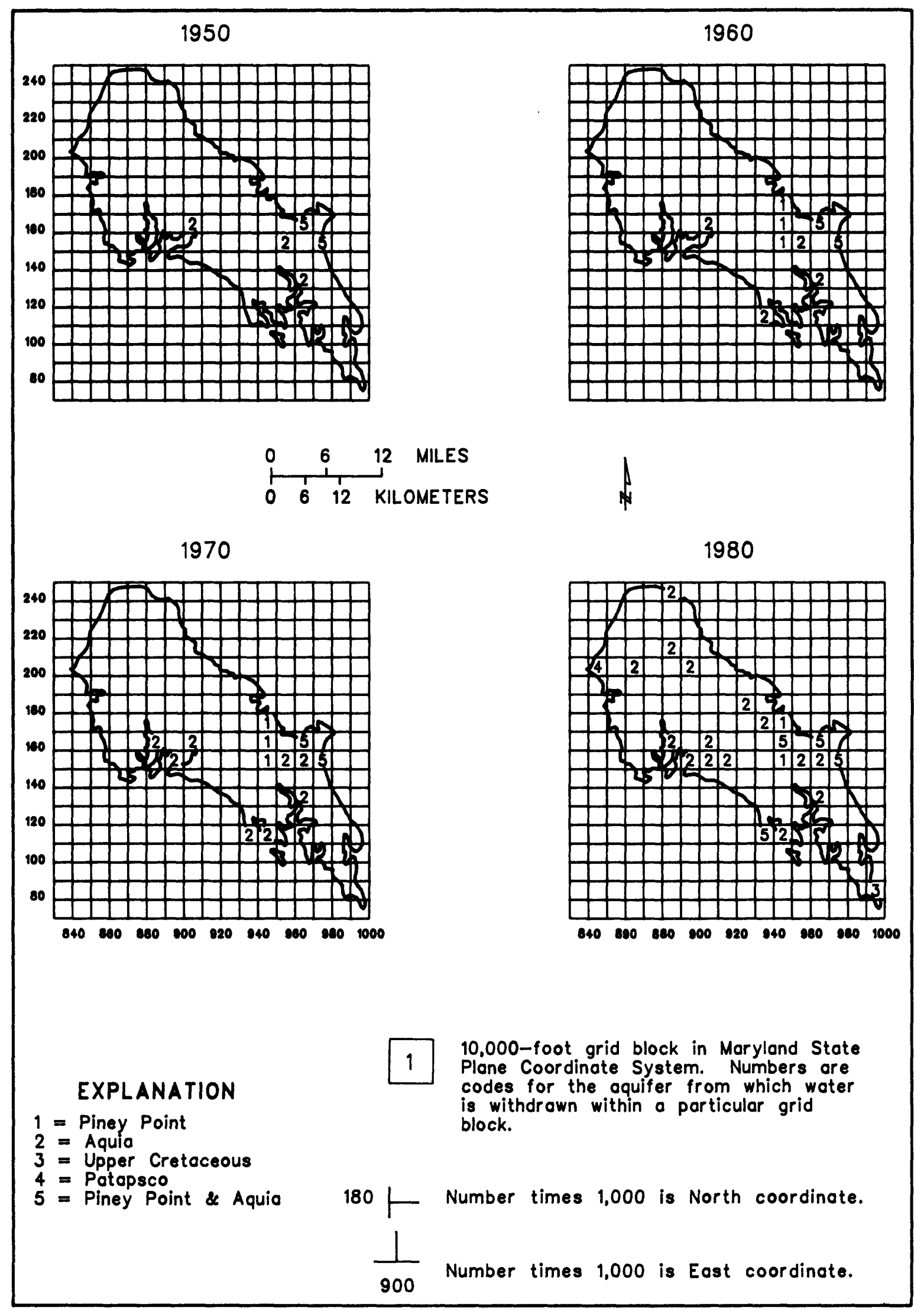

Figure 69.--Locations of large ground-water withdrawals by aquifers in St. Marys County for 1950, 1960, 1970, and 1980. 


\section{SOMERSET COUNTY}

Ground-water use in Somerset County from 1950 through 1980 is shown in figure 70. In 1950, the amount of ground water withdrawn was approximately 1.9 Mgal/d compared to withdrawals of nearly $2.6 \mathrm{Mgal} / \mathrm{d}$ in 1980. This represents an increase of 37 percent for the three decades.

One of the largest uses of ground water in the county was for domestic purposes. In 1950, domestic pumpage was about $1.1 \mathrm{Mgal} / \mathrm{d}$. However, withdrawals gradually declined over the 30-year period to 0.8 $\mathrm{Mgal} / \mathrm{d}$ in 1980 . Water suppliers used about $0.7 \mathrm{Mgal} / \mathrm{d}$ in 1950. These withdrawals increased over the next 24 years to a peak of $1.6 \mathrm{Mgal} / \mathrm{d}$ in 1974 before declining to $1.2 \mathrm{Mgal} / \mathrm{d}$ in 1980 . Water withdrawn for industrial/commercial use was estimated to be less than $0.05 \mathrm{Mgal} / \mathrm{d}$ in 1950 , but had increased to about 0.3 Mgal/d by 1980 .

Large withdrawals of ground water for irrigation in the county began about 1960 . Although there have been no precise measurements of amounts of water pumped by individual irrigators, methods of collecting and reporting these data have improved since the early 1960 's. The most reliable data are from 1970 to 1980. See appendix for ground-water withdrawal data for each large user: User's name, appropriation permit number, source aquifer, location on the Maryland Grid Coordinate System, average daily pumpage, and year pumping began.

The percentages of the total amount of ground water withdrawn for domestic, water supplier, industrial/commercial, and irrigation uses are shown in figure 71. In 1950, domestic use comprised the greatest percentage of ground-water use (62 percent). By 1960 , however, this use had declined to 40 percent and withdrawals by water suppliers accounted for the largest percentage (46 percent). Between 1970 and 1980 , the total amount of water used declined by about $0.3 \mathrm{Mgal} / \mathrm{d}$ and water-use percentages remained virtually the same, indicating a similar percentage decline in each water-use category.

\section{Major Aquifers}

The earliest ground-water pumpage in Somerset County probably came from the surficial (Quaternary) aquifer. Although this aquifer continued to supply much of the low-yield water needs, chiefly for domestic use, a few large users also were able to withdraw sufficient quantities of water from the surficial aquifer. As the demand for water increased, the use of deeper aquifers including the Manokin and Pocomoke (in the upper Chesapeake Group), Magothy, and the Patapsco increased (fig. 72).

From 1952, when large users began withdrawing water from the surficial aquifer, until 1962, pumpage was relatively constant at $0.04 \mathrm{Mgal} / \mathrm{d}$. From 1962 through 1965, withdrawals increased to about 0.14 $\mathrm{Mgal} / \mathrm{d}$, before declining again to $0.04 \mathrm{Mgal} / \mathrm{d}$ in 1966 . Withdrawals remained steady through 1975 when pumpage from the surficial aquifer ceased (see appendix).

Pumpage from the Manokin and Pocomoke aquifers remained relatively unchanged from 1950 through 1965. After 1965, withdrawals increased to about $0.5 \mathrm{Mgal} / \mathrm{d}$ in 1970 and remained about the same through 1980.

Pumpage from the Magothy and Patapsco aquifers stayed about the same from 1950 through 1953. Beginning in 1954, withdrawals increased from both aquifers. This trend continued until 1965 when the rate of pumpage leveled off. Pumpage increased again in the 1970 's, peaking at nearly $0.5 \mathrm{Mgal} / \mathrm{d}$ for the Magothy in 1972 and reaching nearly $1.0 \mathrm{Mgal} / \mathrm{d}$ from the Patapsco in 1978.

\section{Locations of Large Ground-Water Withdrawals}

The locations of withdrawals by large users in Somerset County for 1950, 1960, 1970, and 1980 are shown in figure 73. Table 15 presents water-use data for the large users located within particular grid blocks for the year indicated on the map. In 1950, pumpage was limited to the north-central and southwestern sections of the county and this areal distribution remained relatively unchanged through 1960 . Between 1970 and 1980 , withdrawals increased on the eastern and western boundaries of the county.

The locations of withdrawals from individual aquifers supplying the large users in Somerset County (described in table 15 and fig. 73) are shown in figure 74. Withdrawals from the Manokin and Pocomoke aquifers were confined to the north-central part of the county in 1950 and 1960, but increased along the eastern boundary by 1970 and 1980 . Pumpage from the Magothy and Patapsco aquifers was primarily limited to a location in the southwestern corner of the county for all 4 years shown, except for a site on the western boundary which used the Patapsco aquifer in 1980. 


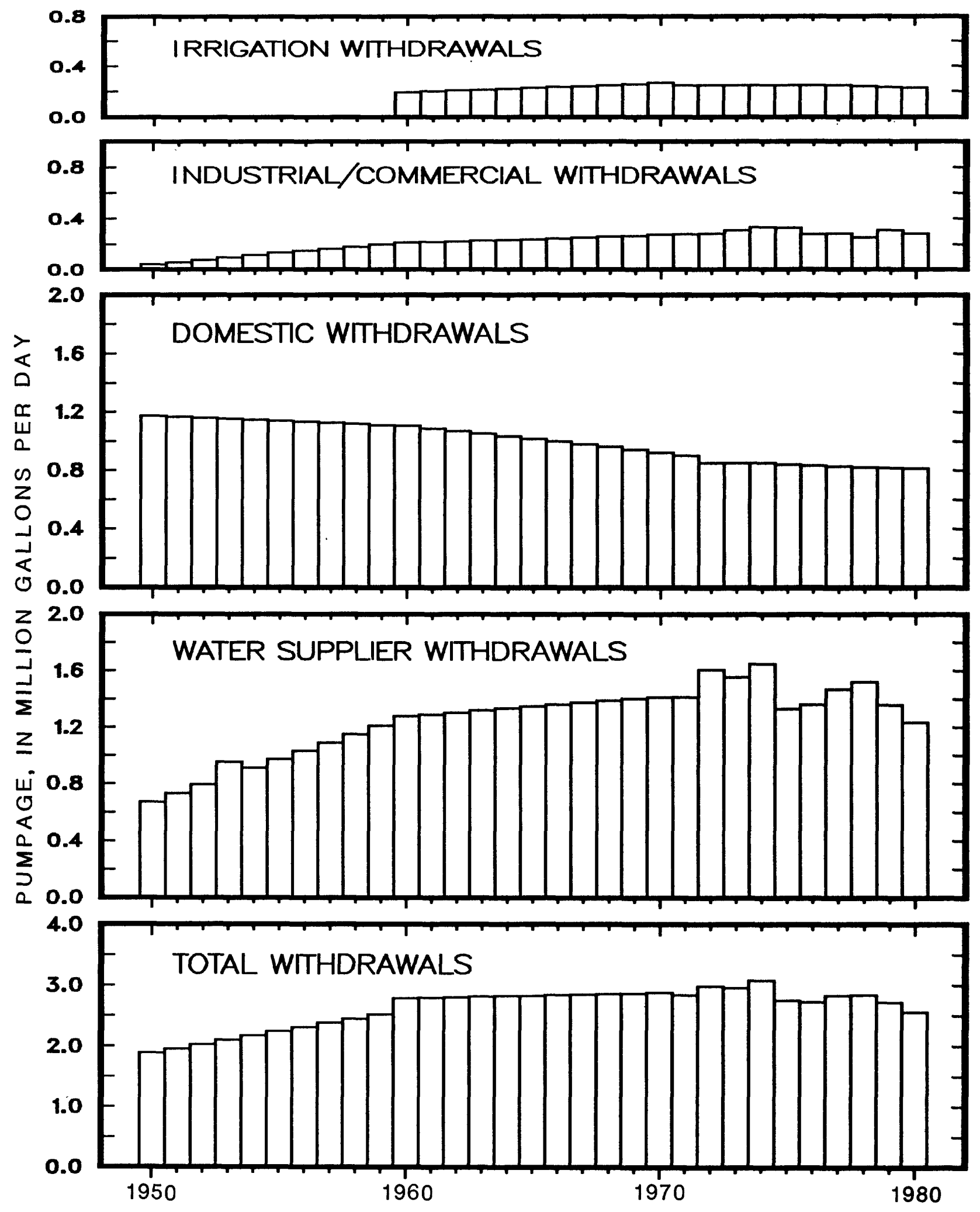

Figure 70.--Ground-water withdrawals by use in Somerset County from 1950 through 1980. 

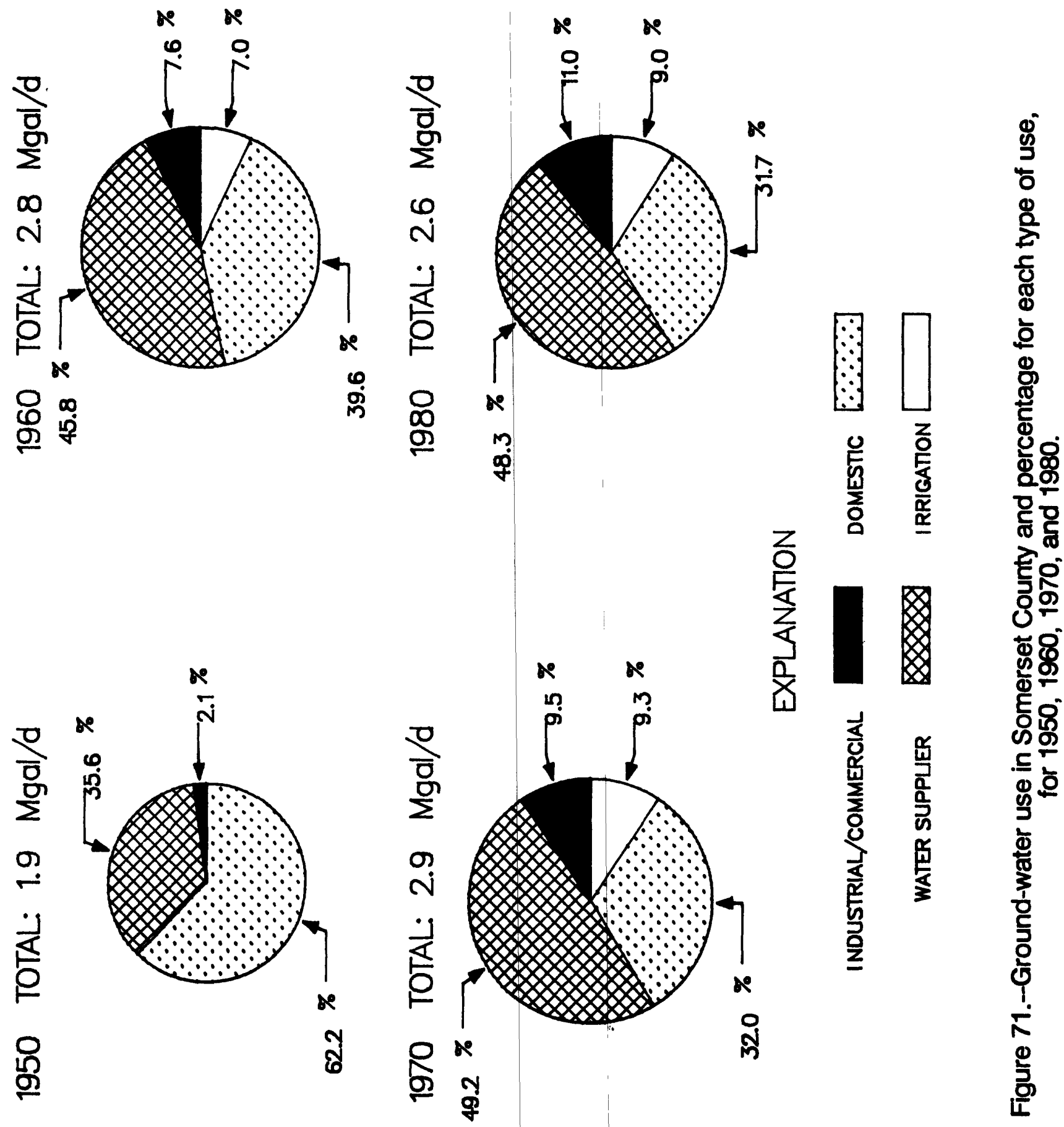


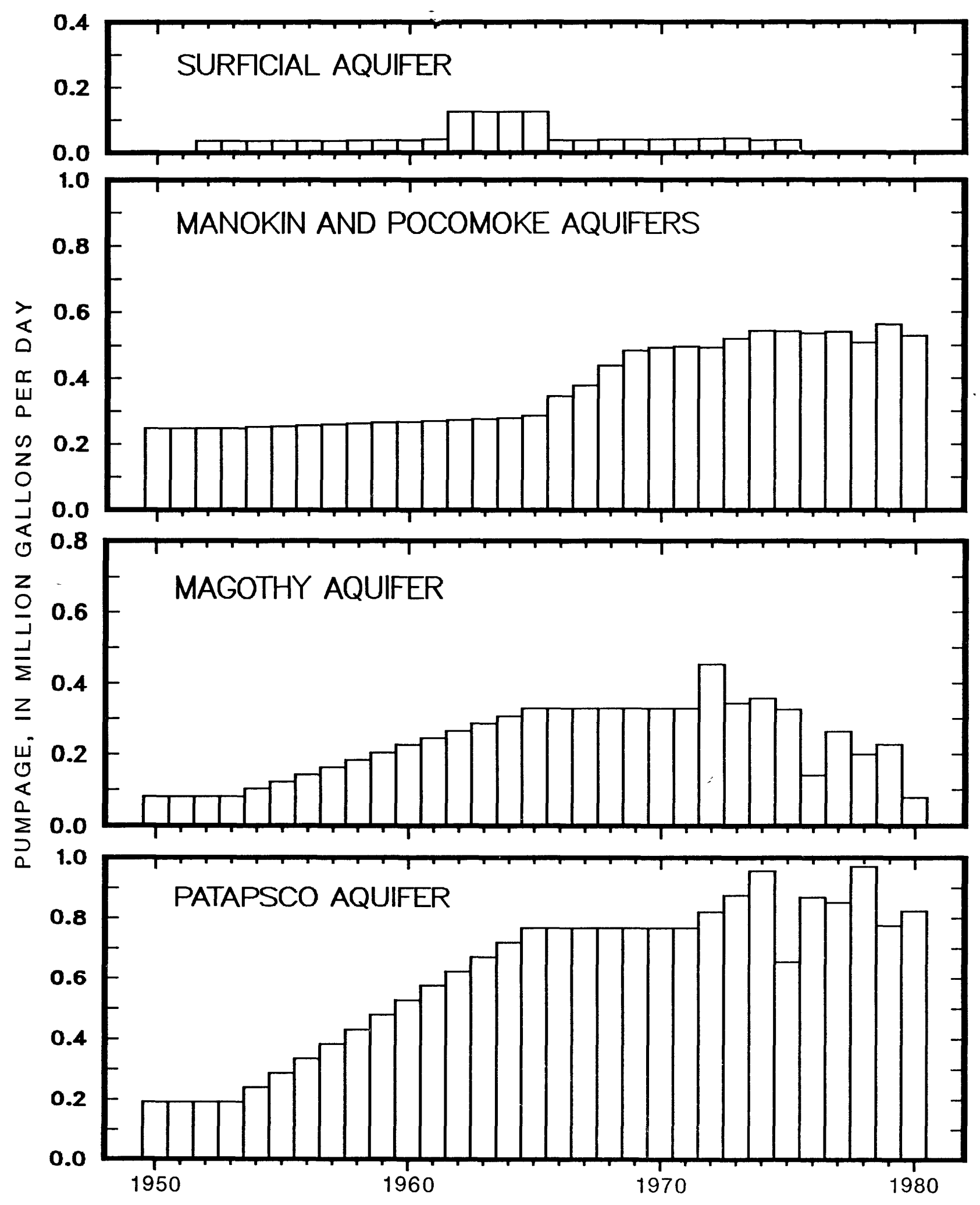

Figure 72.--Large ground-water withdrawals by aquifers in Somerset County from 1950 through 1980. 


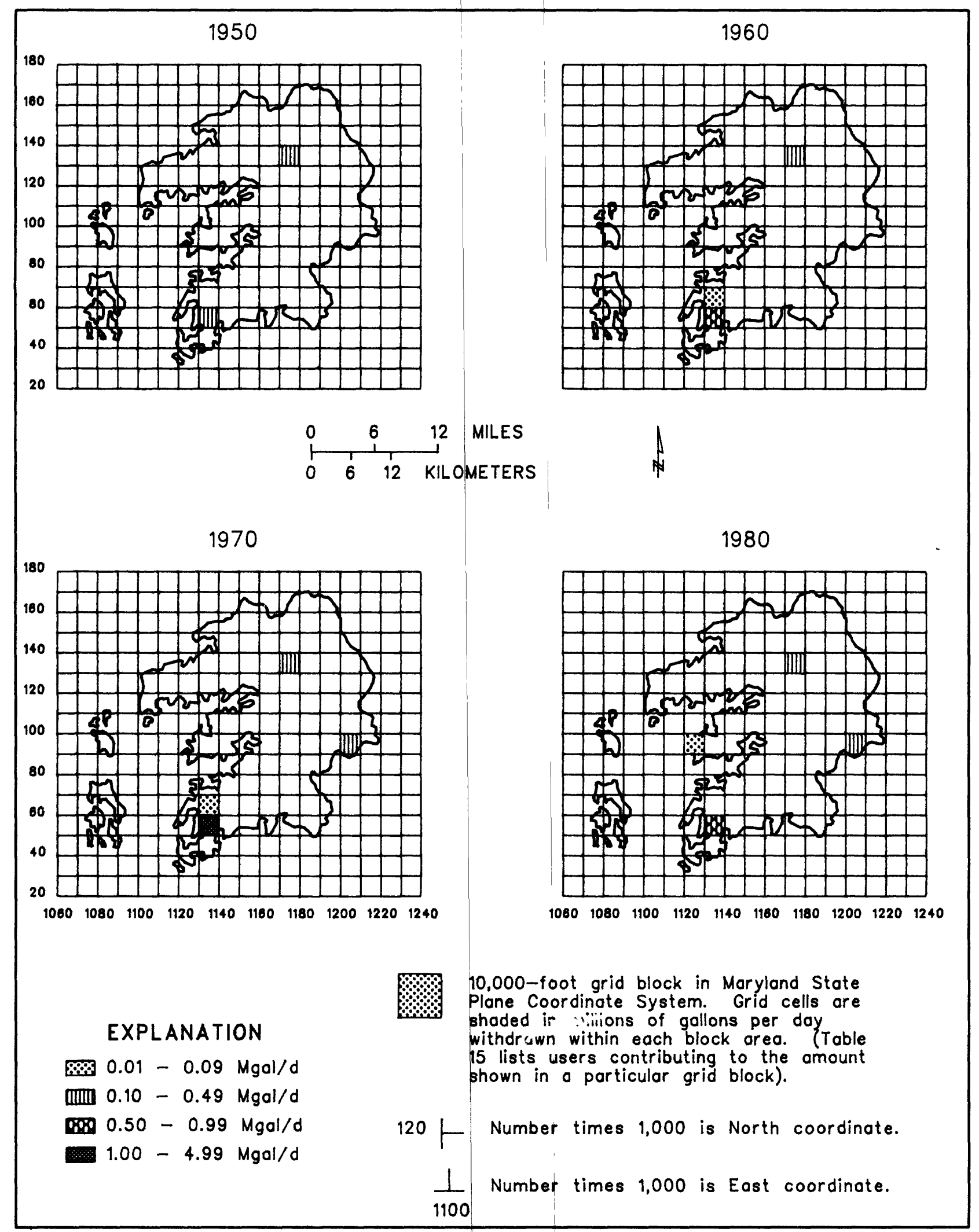

Figure 73.--Locations of large ground-water withdrawals in Somerset County for 1950 , 1960, 1970, and 1980. 
Table 15.--Large ground-water users in Somerset County in 1950, 1960, 1970, and 1980, summarized by the Maryland Grid Coordinate System

\begin{tabular}{|c|c|c|c|c|}
\hline Year & Grid block & User & $\begin{array}{l}\text { umpese } \\
\text { (yeldid) }\end{array}$ & Aquiler \\
\hline 1950 & $\begin{array}{l}\text { N050 } \mathbf{E} 1130 \\
\text { N130 } \mathbf{E 1 1 7 0}\end{array}$ & $\begin{array}{l}\text { Crisfield, City of } \\
\text { do. } \\
\text { Princess Anne, } \\
\text { Somerset County Sanitary District }\end{array}$ & $\begin{array}{r}0.08 \\
.19 \\
.25\end{array}$ & $\begin{array}{l}\text { Patepseo } \\
\text { Magothy } \\
\text { Manokin }\end{array}$ \\
\hline 1960 & $\begin{array}{ll}\text { N050 } & \text { E1130 } \\
\text { N060 } & E 1130 \\
\text { N130 } & \text { E1170 }\end{array}$ & $\begin{array}{l}\text { Crisfield, City of } \\
\text { do. } \\
\text { Carvel Bail Cutlery } \\
\text { Princess Anne, } \\
\quad \text { Somerset County Sanitary District }\end{array}$ & $\begin{array}{r}0.23 \\
.53 \\
.04 \\
.27\end{array}$ & $\begin{array}{l}\text { Patopseo } \\
\text { Magothy } \\
\text { Quntormas } \\
\text { Manotin }\end{array}$ \\
\hline 1970 & $\begin{array}{ll}\text { N050 } & \text { E1130 } \\
\text { N060 } & \text { E1130 } \\
\text { N080 } & \text { E1200 } \\
\text { N130 } & \text { E1170 }\end{array}$ & $\begin{array}{l}\text { Crisfield, City of } \\
\text { do. } \\
\text { Carvel Bali Cutlery } \\
\text { Chesapeake Bay Plywood Corporation } \\
\text { Princess Anne Wells, } \\
\text { Somerset County Sanitary District }\end{array}$ & $\begin{array}{r}0.33 \\
.77 \\
.04 \\
.18 \\
.32\end{array}$ & $\begin{array}{l}\text { Patapseo } \\
\text { Magothy } \\
\text { Quaternary } \\
\text { Poconoke } \\
\text { Manokin }\end{array}$ \\
\hline 1980 & $\begin{array}{l}\text { No50 } \mathbf{E} 1130 \\
\text { No90 } \\
\text { E1120 } \\
\text { N090 } \\
\text { N130 } \\
\mathbf{E} 11200\end{array}$ & $\begin{array}{l}\text { Crisfield, City of } \\
\text { do. } \\
\text { Frenchtown, } \\
\text { Somerset County Sanitary District } \\
\text { Chesapeake Bay Plywood Corporation } \\
\text { Princess Anne Wells, } \\
\text { Somerset County Sanitary District }\end{array}$ & $\begin{array}{r}0.08 \\
.81 \\
.01 \\
.19 \\
.34\end{array}$ & $\begin{array}{l}\text { Patapsco } \\
\text { Magothy } \\
\text { Petopseo } \\
\text { Poconoke } \\
\text { Manotin }\end{array}$ \\
\hline
\end{tabular}




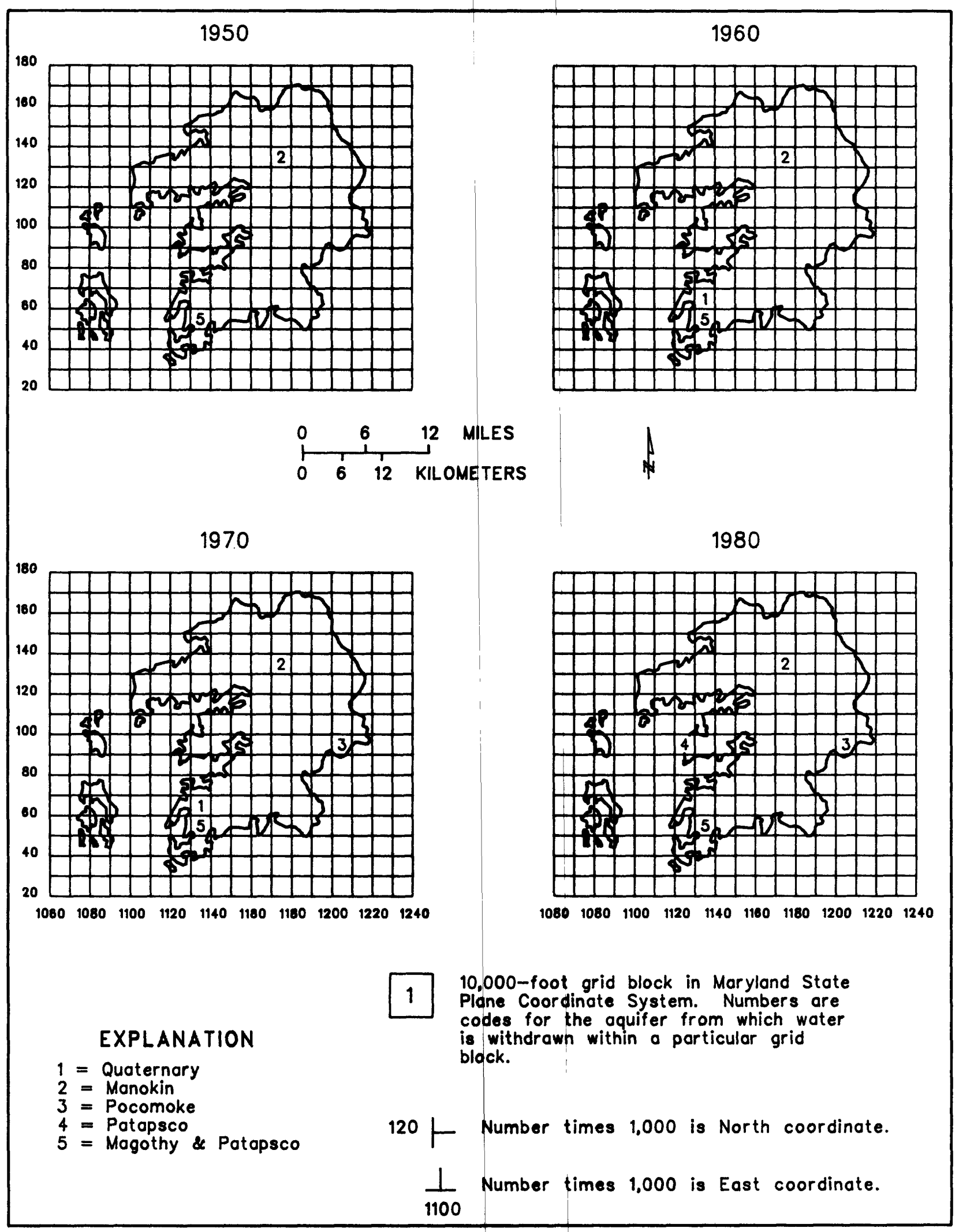

Figure 74.--Locations of large ground-water withdrawals by aquifers in Somerset County for 1950, 1960, 1970, and 1980. 


\section{TALBOT COUNTY}

Ground-water use in Talbot County from 1950 through 1980 is shown in figure 75. In 1950, the amount of ground water withdrawn was approximately 2.1 Mgal/d compared to withdrawals of nearly $3.7 \mathrm{Mgal} / \mathrm{d}$ in 1980. This represents an increase of 76 percent for the three decades.

Since 1950, water use in Talbot County increased in all categories, with one of the largest withdrawals being for domestic use. In 1950, domestic withdrawals were approximately $0.7 \mathrm{Mgal} / \mathrm{d}$ compared to about 1.0 $\mathrm{Mgal} / \mathrm{d}$ in 1980 . Withdrawals by water suppliers were about $0.8 \mathrm{Mgal} / \mathrm{d}$ in 1950 . By 1980 , this pumpage had increased to more than $1.6 \mathrm{Mgal} / \mathrm{d}$. Industrial/commercial withdrawals were about $0.6 \mathrm{Mgal} / \mathrm{d}$ in 1950 and remained relatively the same until 1975 , when they declined to about $0.4 \mathrm{Mgal} / \mathrm{d}$. By 1980 , however, withdrawals had increased again to $0.6 \mathrm{Mgal} / \mathrm{d}$.

The use of ground water for irrigation by large users in the county began about 1960 , with pumpage estimated to be about $0.1 \mathrm{Mgal} / \mathrm{d}$. By 1980 , withdrawals had increased to about $0.4 \mathrm{Mgal} / \mathrm{d}$. See appendix for ground-water withdrawal data for each large user: User's name, appropriation permit number, source aquifer, location on the Maryland Grid Coordinate System, average daily pumpage, and year pumping began.

The percentages of the total amount of ground water withdrawn for domestic, water supplier, industrial/commercial, and irrigation uses are shown in figure 76. In 1950, 1960, and 1970, the percentages of total ground water for both domestic and water supplier uses were similar. In 1980, however, the percentage for water suppliers increased to 43 percent, whereas the percentage for domestic use declined to 29 percent. Irrigation comprised only 3.5 percent of the total water used in 1960 , but, by 1980 , it had increased to 11 percent.

\section{Major Aqulfers}

The earliest ground-water pumpage in Talbot County came from the surficial (Quaternary) aquifer. Although these shallow sands principally supplied much of the low-yield water needs, chiefly domestic use, there was some early use of the surficial aquifer by large users. As the demand for water increased, the use of deeper aquifers, particularly the Cheswold and Federalsburg (in the lower Chesepeake Group), Piney
Point, Aquia, and Magothy, increased. Large user withdrawals by aquifer from 1950 through 1980 are shown in figure 77.

Withdrawals from the surficial aquifer remained about $0.2 \mathrm{Mgal} / \mathrm{d}$ until 1976, when they increased to about $0.37 \mathrm{Mgal} / \mathrm{d}$. The highest pumpage during the 30-year period occurred in 1977 at approximately 0.43 $\mathrm{Mgal} / \mathrm{d}$, then declined to $0.35 \mathrm{Mgal} / \mathrm{d}$ in 1980 . Withdrawals from the aquifers of the lower Chesapeake Group were about $0.18 \mathrm{Mgal} / \mathrm{d}$ in 1950 . By 1973, pumpage had declined to less than $0.05 \mathrm{Mgal} / \mathrm{d}$, but gradually increased again to $0.15 \mathrm{Mgal} / \mathrm{d}$ in 1980 .

Use of the Piney Point aquifer by large users began in 1952 at approximately $0.2 \mathrm{Mgal} / \mathrm{d}$, gradually increasing to $0.3 \mathrm{Mgal} / \mathrm{d}$ in 1963 . Withdrawals remained at this level until 1975, when they declined to about $0.2 \mathrm{Mgal} / \mathrm{d}$ and continued to gradually decrease to about 0.18 $\mathrm{Mgal} / \mathrm{d}$ by 1980 . Withdrawals by large users of the Aquia aquifer were less than $0.05 \mathrm{Mgal} / \mathrm{d}$ in 1950 , but increased to nearly $0.45 \mathrm{Mgal} / \mathrm{d}$ by 1980 .

The Magothy aquifer supplied most of the ground water to large users during the 30-year period. In 1950, about $0.38 \mathrm{Mgal} / \mathrm{d}$ was withdrawn. Following a decline to just less than $0.3 \mathrm{Mgal} / \mathrm{d}$ in 1951 , withdrawals increased over the next 25 years to a peak of about 0.98 $\mathrm{Mgal} / \mathrm{d}$ in 1976. Pumpage then declined to nearly 0.86 $\mathrm{Mgal} / \mathrm{d}$ in 1980.

\section{Locations of Large Ground-Water Withdrawals}

The locations of withdrawals by large users in Talbot County for 1950, 1960, 1970, and 1980 are shown in figure 78. Table 16 presents water-use data for the large users located within particular grid blocks for the year indicated on the map. The areal distribution of use remained relatively the same for each of the years shown, although the number of sites of withdrawal increased from 1950 to 1980 .

The locations of withdrawals from individual aquifers supplying the large users (described in table 16 and fig. 78) are shown in figure 79. Use of the Aquia aquifer was limited to the west-central part of the county, but its use increased from 1气50 to 1980 . From 1950 to 1980 , use of the Magothy aquifer was limited to one location in central Talbot County. 


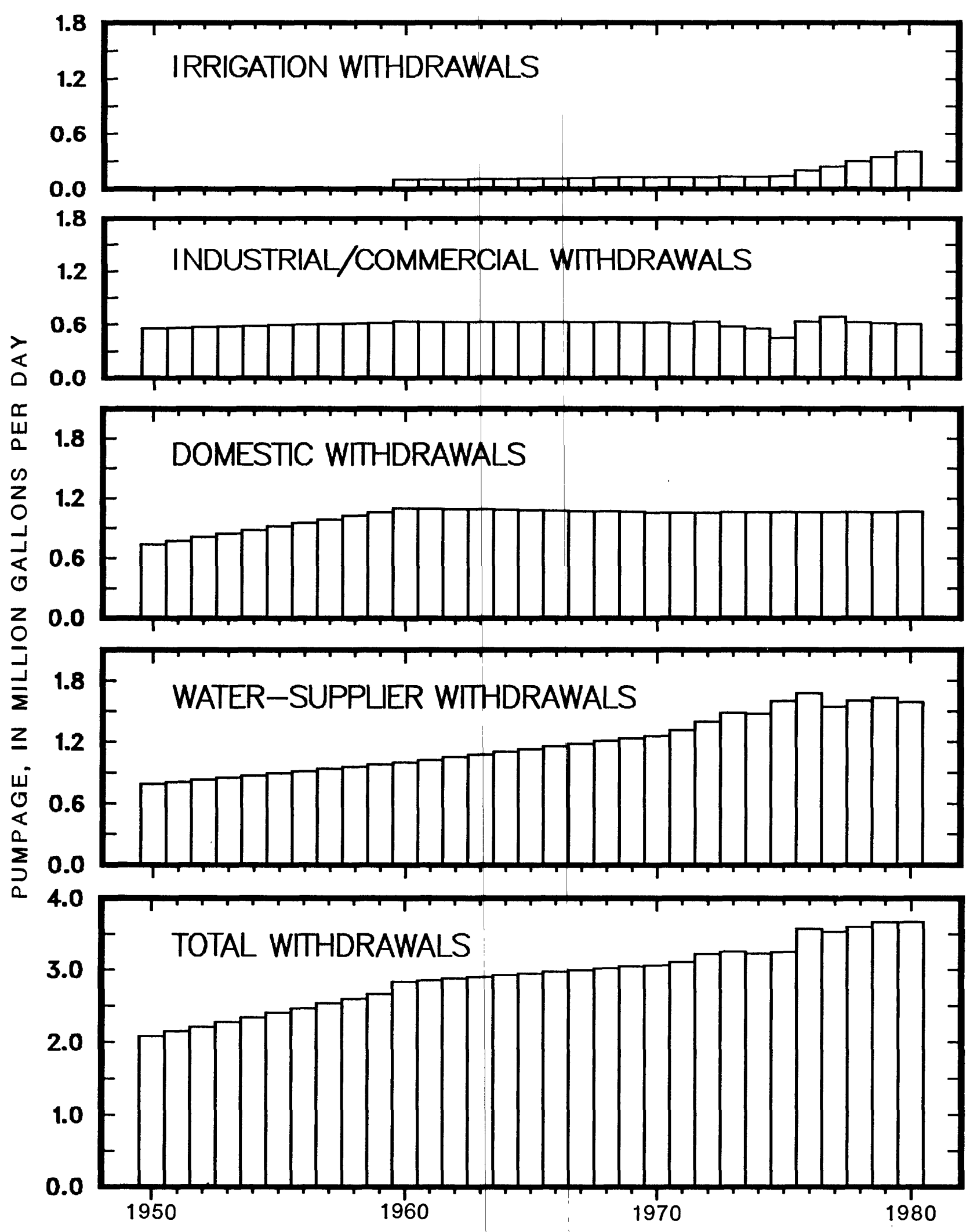

Figure 75.--Ground-water withdrawals by use in Talbot County from 1950 through 1980. 

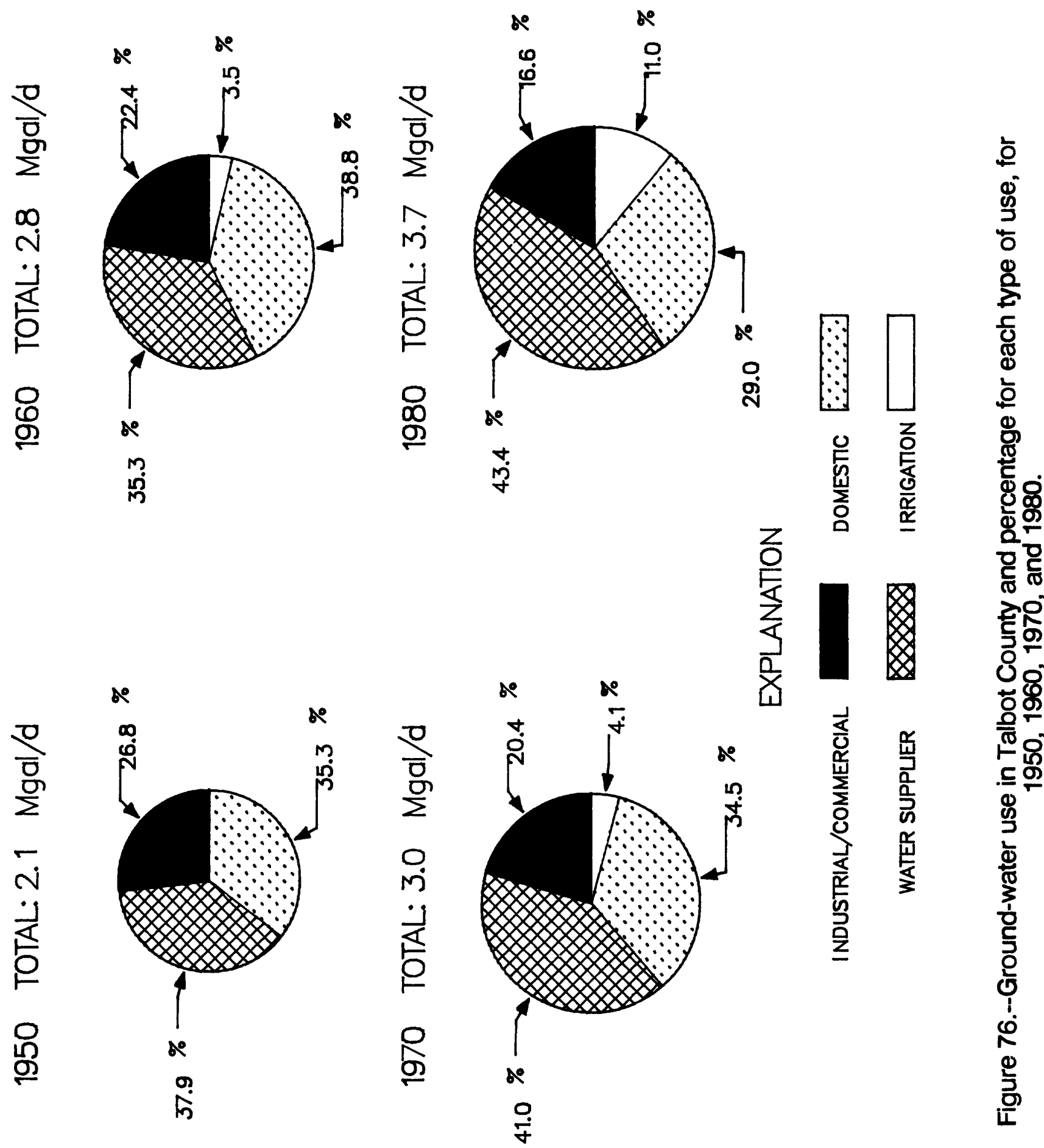


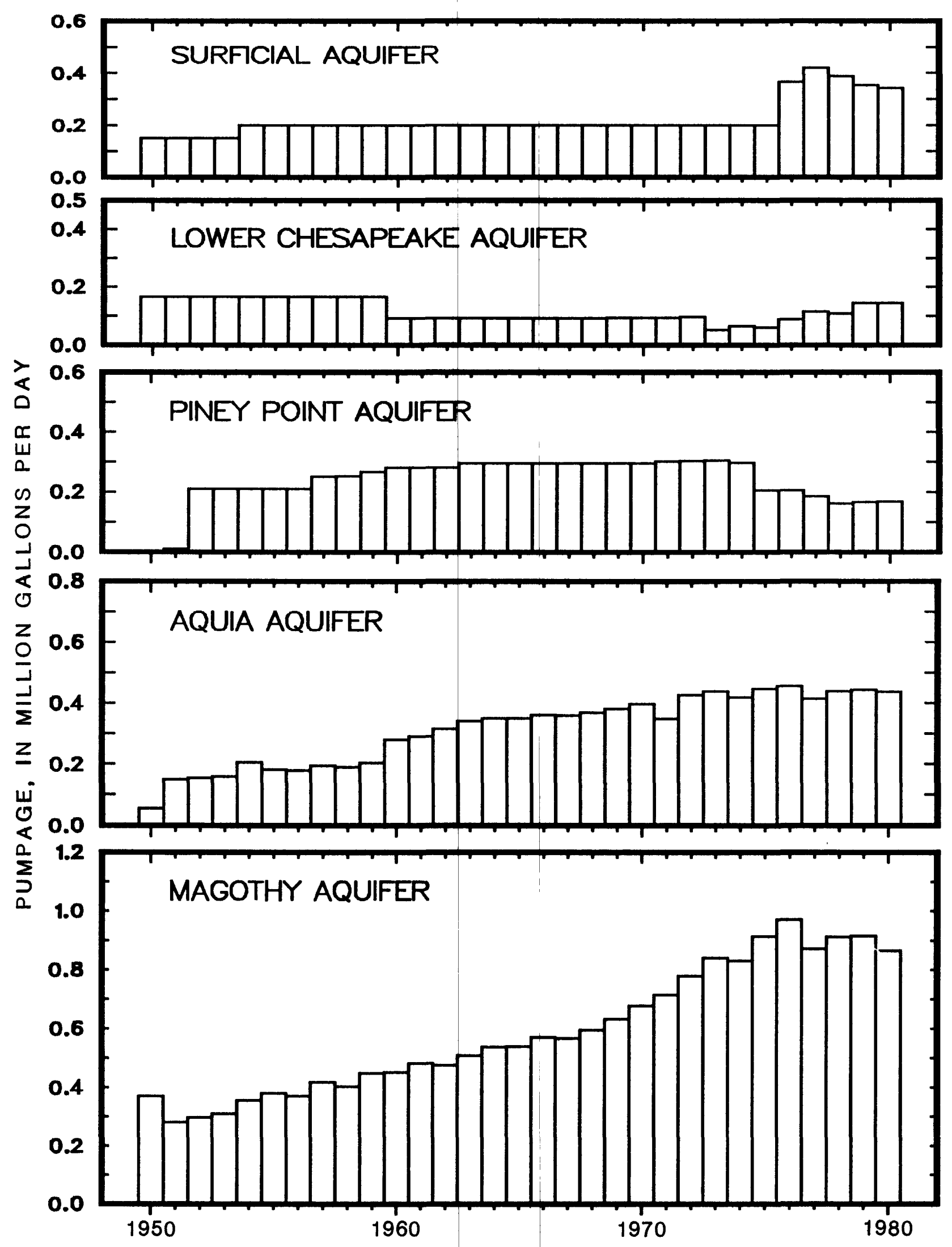

Figure 77.--Large ground-water withdrawals by aquifers in Talbot County from 1950 through 1980. 


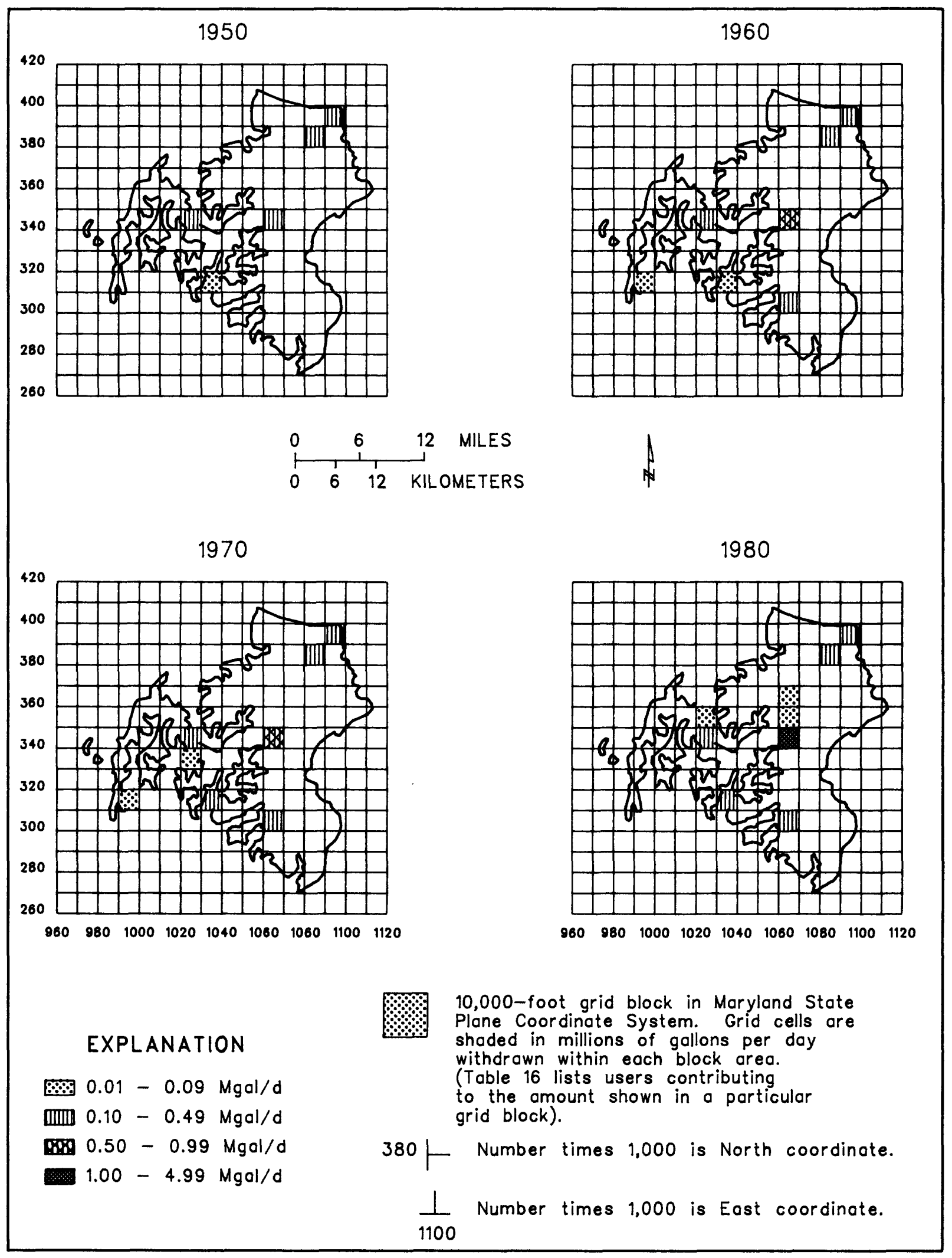

Figure 78.--Locations of large ground-water withdrawals in Talbot County for 1950 , 1960, 1970, and 1980. 
Table 16.--Large ground-water users in Talbot County in 1950, 1960, 1970, and 1980, summarized by the Maryland Grid Coordinate System

\begin{tabular}{|c|c|c|c|c|}
\hline Year & Grid block & User & $\begin{array}{l}\text { Pumpage } \\
\text { (Mgal/d) }\end{array}$ & Aquifer \\
\hline 1950 & $\begin{array}{ll}\text { N310 } & \text { E1030 } \\
\text { N340 } & \text { E1020 } \\
\text { N340 } & \text { E1060 } \\
& \\
\text { N380 } & \text { E1080 } \\
\text { N390 } & \text { E1090 }\end{array}$ & $\begin{array}{l}\text { Oxford, Town of } \\
\text { St. Michaels, City of } \\
\text { Tidewater Inn } \\
\text { Easton Utilities Commission } \\
\text { Allen Family Foods } \\
\text { KMC Foods, Inc. }\end{array}$ & $\begin{array}{l}0.05 \\
.10 \\
.02 \\
.37 \\
.15 \\
.15\end{array}$ & $\begin{array}{l}\text { Aquia } \\
\text { Aquia } \\
\text { Federalsburg } \\
\text { Magothy } \\
\text { Quaternary } \\
\text { Cheswold }\end{array}$ \\
\hline 1960 & $\begin{array}{ll}\text { N300 } & \text { E1060 } \\
\text { N310 } & \text { E } 990 \\
\text { N310 } & \text { E1030 } \\
\text { N340 } & \text { E1020 } \\
\text { N340 } & \text { E1060 } \\
& \\
\text { N380 } & \text { E1080 } \\
\text { N390 } & \text { E1090 }\end{array}$ & $\begin{array}{l}\text { Trappe Frozen Foods } \\
\text { Trappe, Town of } \\
\text { Tilghman Packing } \\
\text { Oxford, Town of } \\
\text { St. Michaels, City of } \\
\text { Tidewater Inn } \\
\text { Easton Utilitios Commission } \\
\text { Allen Family Foods } \\
\text { KMC Foods, Inc. } \\
\text { do. }\end{array}$ & $\begin{array}{l}0.23 \\
.04 \\
.01 \\
.05 \\
.16 \\
.02 \\
.15 \\
.45 \\
.20 \\
.08 \\
.08\end{array}$ & $\begin{array}{l}\text { Piney Point } \\
\text { Piney Point } \\
\text { Piney Point } \\
\text { Aquia } \\
\text { Aquia } \\
\text { Federalsburg } \\
\text { Aquia } \\
\text { Magothy } \\
\text { Quaternary } \\
\text { Aquia } \\
\text { Cheswold }\end{array}$ \\
\hline 1970 & $\begin{array}{ll}\text { N300 } & \text { E1060 } \\
\text { N310 } & \text { E } 990 \\
\text { N310 } & \text { E1030 } \\
\text { N330 } & \text { E1020 } \\
\text { N340 } & \text { E1020 } \\
\text { N340 } & \text { E1060 } \\
& \\
\text { N380 } & \text { E1080 } \\
\text { N390 } & \text { E1090 }\end{array}$ & $\begin{array}{l}\text { Trappe Frozen Foods } \\
\text { Trappe, Town of } \\
\text { Tilghman Packing } \\
\text { Oxford, Town of } \\
\text { Country Pride Foods } \\
\text { St. Michaels, City of } \\
\text { Tidewater Inn } \\
\text { Easton Utilities Commission } \\
\text { Allen Family Foods } \\
\text { KMC Foods, Inc. } \\
\text { do. }\end{array}$ & $\begin{array}{l}0.25 \\
.04 \\
.01 \\
.10 \\
.01 \\
.22 \\
.02 \\
.22 \\
.68 \\
.20 \\
.06 \\
.08\end{array}$ & $\begin{array}{l}\text { Piney Point } \\
\text { Piney Point } \\
\text { Piney Point } \\
\text { Aquia } \\
\text { Aquia } \\
\text { Aquia } \\
\text { Federalsburg } \\
\text { Aquia } \\
\text { Magothy } \\
\text { Quaternary } \\
\text { Aquia } \\
\text { Cheswold }\end{array}$ \\
\hline 1980 & $\begin{array}{ll}\text { N300 } & \text { E1060 } \\
\text { N310 } & \text { E1030 } \\
\text { N340 } & \text { E1020 } \\
\text { N340 } & \text { E1060 } \\
& \\
\text { N350 } & \text { E1020 } \\
\text { N350 } & \text { E1060 } \\
\text { N360 } & \text { E1060 } \\
\text { N380 } & \text { E1080 } \\
\text { N390 } & \text { E1090 }\end{array}$ & $\begin{array}{l}\text { Trappe Frozen Foods } \\
\text { Trappe, Town of } \\
\text { Oxford, Town of } \\
\text { St. Michaels, City of } \\
\text { Tidewater Inn } \\
\text { Easton Utilities Commission } \\
\text { do. } \\
\text { Martingham Utility } \\
\text { Talbot Trailer Park } \\
\text { Bogs Neck Golf Course } \\
\text { do. } \\
\text { Allen Family Foods } \\
\text { KMC Foods, Inc. } \\
\text { do. }\end{array}$ & $\begin{array}{l}0.10 \\
.07 \\
.11 \\
.23 \\
.02 \\
.29 \\
.87 \\
.01 \\
.01 \\
.01 \\
.07 \\
.27 \\
.02 \\
.10\end{array}$ & $\begin{array}{l}\text { Piney Point } \\
\text { Piney Point } \\
\text { Aquia } \\
\text { Aquia } \\
\text { Federalsburg } \\
\text { Aquia } \\
\text { Magothy } \\
\text { Aquia } \\
\text { Cheswold } \\
\text { Federalsburg } \\
\text { Quaternary } \\
\text { Quaternary } \\
\text { Aquia } \\
\text { Cheswold }\end{array}$ \\
\hline
\end{tabular}




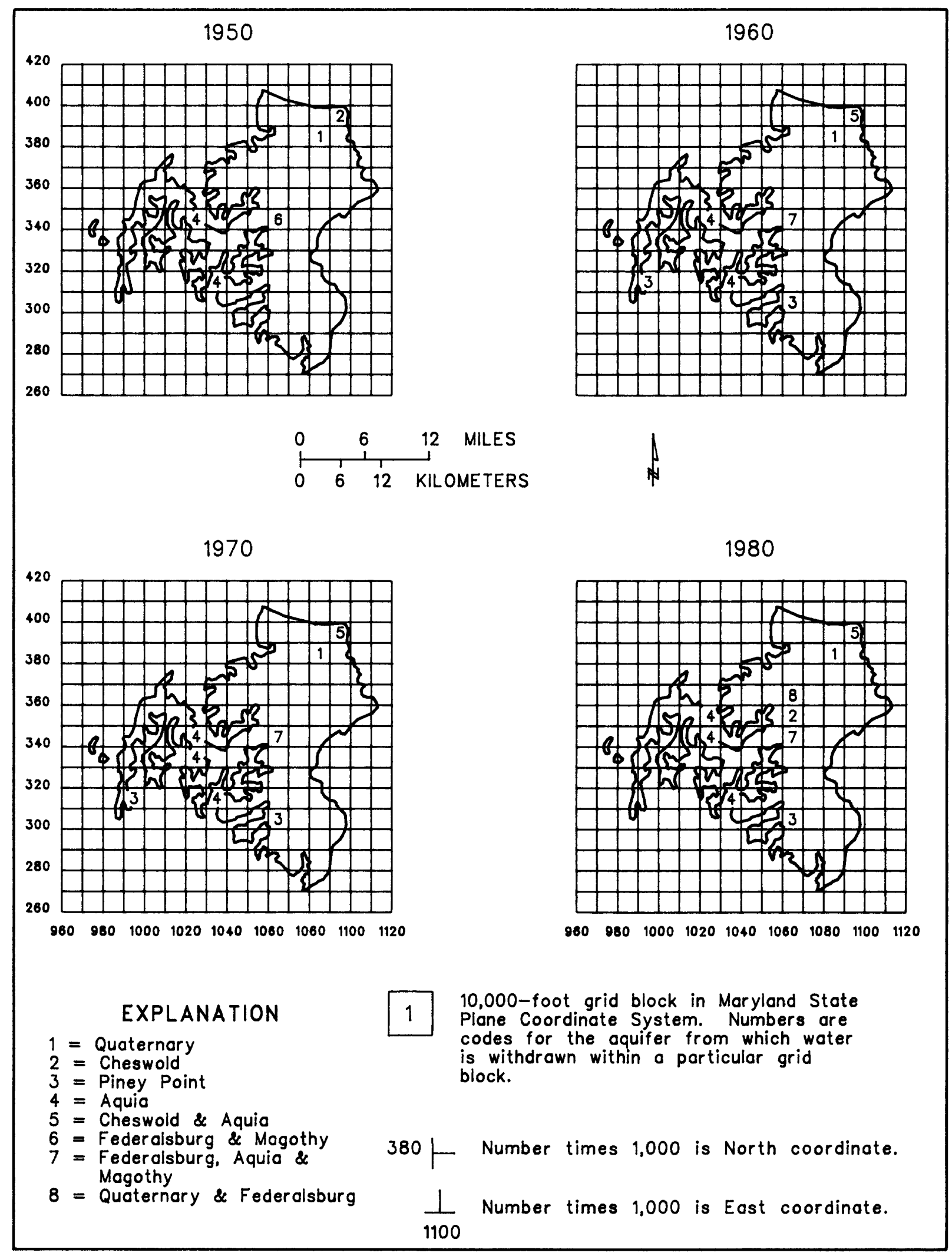

Figure 79.--Locations of large ground-water withdrawals by aquifers in Talbot County for 1950, 1960, 1970, and 1980. 


\section{WICOMICOICOUNTY}

Ground-water use in Wicomico County from 1950 through 1980 is shown in figure 80. In 1950, the amount of ground water withdrawn was approximately 6.0 $\mathrm{Mgal} / \mathrm{d}$ compared to withdrawals of nearly $12.0 \mathrm{Mgal} / \mathrm{d}$ in 1980. This represents an increase of 100 percent for the three decades.

Since 1950, water use increased in all categories at a rate of about $0.18 \mathrm{Mgal} / \mathrm{yr}$ for total withdrawals. In 1950, domestic withdrawals were about $1.0 \mathrm{Mgal} / \mathrm{d}$ compared to more than $2.5 \mathrm{Mgal} / \mathrm{d}$ in 1980 . Withdrawals by water suppliers increased from about $2.5 \mathrm{Mgal} / \mathrm{d}$ in 1950 to $4.1 \mathrm{Mgal} / \mathrm{d}$ in 1980 . Industrial/commercial use was about $2.5 \mathrm{Mgal} / \mathrm{d}$ in 1950 and increased to $3.5 \mathrm{Mgal} / \mathrm{d}$ in 1980. Large withdrawals of ground water for irrigation in the county began about 1960 . Although there have been no precise measurements of amounts of water pumped by individual irrigators, methods of collecting and reporting these data have improved since the early 1960 's. The most reliable data are from 1970 to 1980 . It was estimated that withdrawals for irrigation were about $0.2 \mathrm{Mgal} / \mathrm{d}$ in 1960 and increased to approximately $1.6 \mathrm{Mgal} / \mathrm{d}$ by 1980 . See appendix for ground-water withdrawal data for each large user: User's name, appropriation permit number, source aquifer, location on the Maryland Grid Coordinate System, average daily pumpage, and year pumping began.

The percentages of the total amount of ground water withdrawn for domestic, water supplier, industrial/commercial, and irrigation uses are shown in figure 81 . In 1950, the percentage for industrial/commercial use represented nearly half of the total water withdrawn in the county (about 44 percent). However, by 1980 the percentage for this use had dropped to about 30 percent. The percentage for irrigation was only about 3 percent in 1960, but by 1980 it had increased to 13 percent of the total ground water withdrawn.

\section{Major Aquifers}

The earliest ground-water pumpage in Wicomico County came from the shallow surficial (Quaternary) aquifer. This aquifer continued to supply most of the water needs of large users, as well as for domestic use. However, the deeper Manokin aquifer also was used. Large user withdrawals by aquifer from 1950 through 1980 are shown in figure 82.

In 1950, the amount of water withdrawn from the surficial aquifer was about $3.3 \mathrm{Mgal} / \mathrm{d}$ compared to more than $7.5 \mathrm{Mgal} / \mathrm{d}$ by 1980 . Withdrawals from the Manokin aquifer were about $0.35 \mathrm{Mgal} / \mathrm{d}$ in 1950 and increased to more than $0.5 \mathrm{Mgal} / \mathrm{d}$ during the 1970 's, but declined to about $0.1 \mathrm{Mgal} / \mathrm{d}$ by 1980 .

\section{Locations of Large Ground-Water Withdrawals}

The locations of withdrawals by large users in Wicomico County for 1950, 1960, 1970, and 1980 are shown in figure 83. Table 17 presents water-use data for the large users located within particular grid blocks for the year indicated on the map. The location of greatest withdrawals for all the years shown was the Salisbury area in the central part of the county. The maps also show an increase in the number of sites of large withdrawals throughout the county from 1950 to 1980.

The locations of withdrawals from individual aquifers supplying the large users in Wicomico County (described in table 17 and fig. 83) are shown in figure 84. In 1950, withdrawals from the surficial and Manokin aquifers were located in the central and southeastern part of the county. The maps for subsequent years show wider distribution of use for these aquifers. The Piney Point aquifer, shown on the 1960 and 1970 maps, was used in only one location in the southwestern corner of the county.

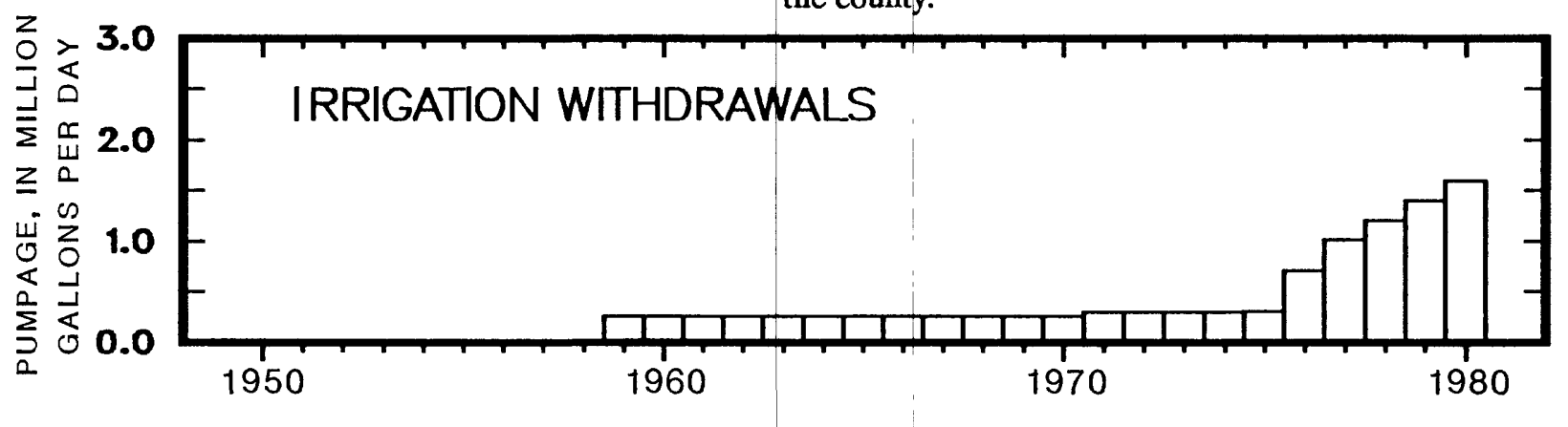

Figure 80.--Ground-water withdrawals by use in Wicomico County from 1950 through 1980. 


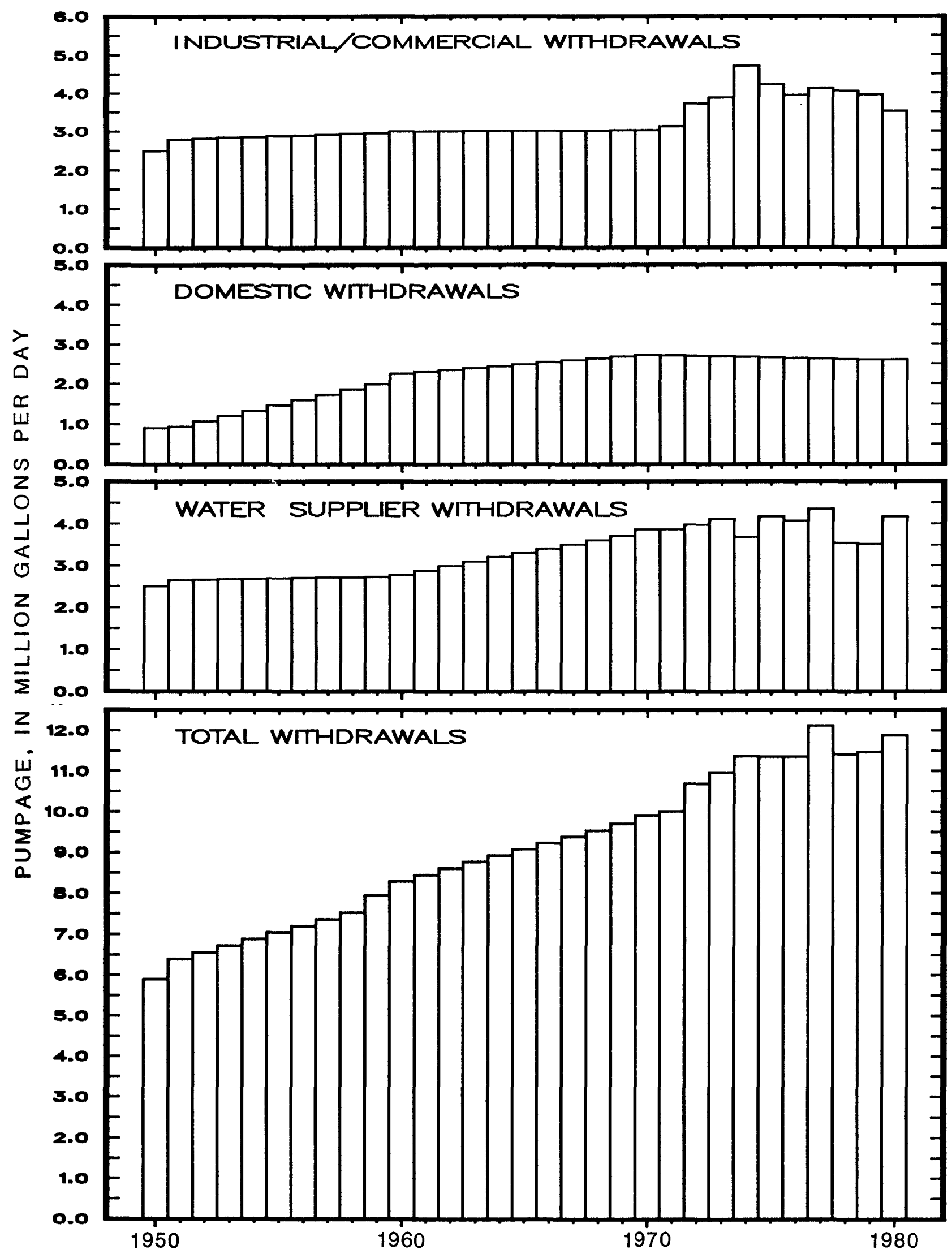

Figure 80.--Ground-water withdrawals by use in Wicomico County from 1950 through 1980--Continued. 


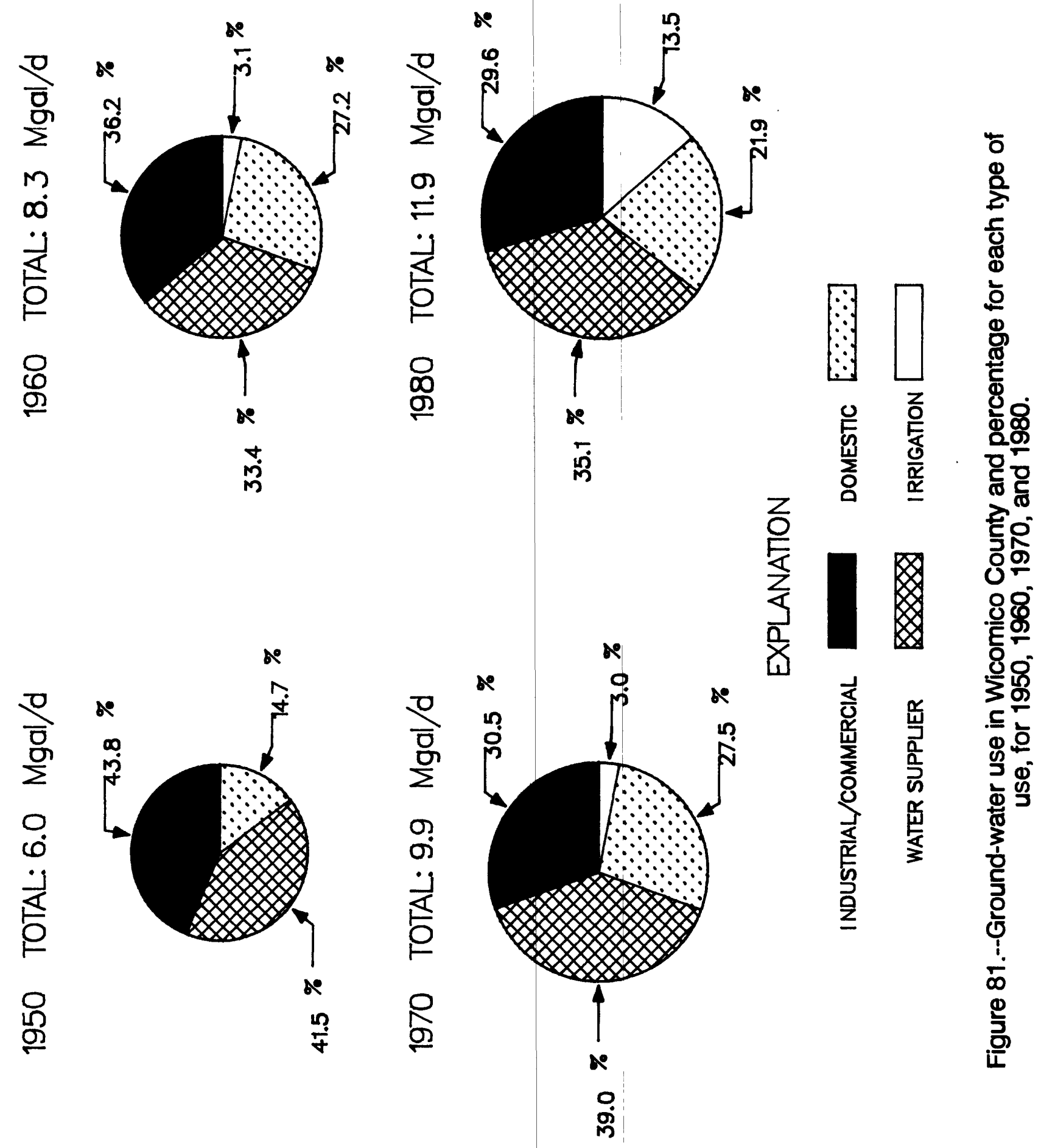




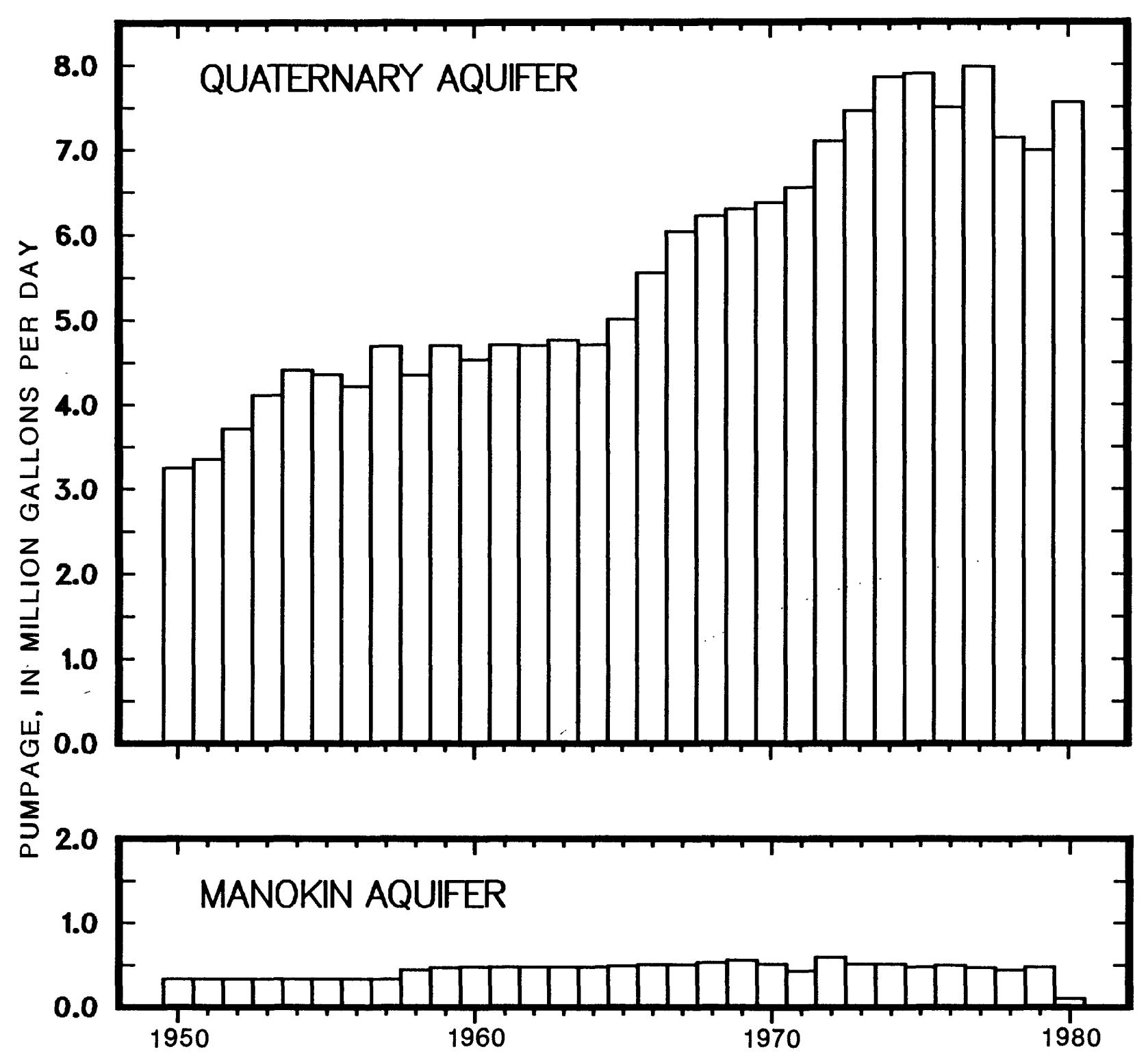

Figure 82.--Large ground-water withdrawals by aquifers in Wicomico County from 1950 through 1980. 


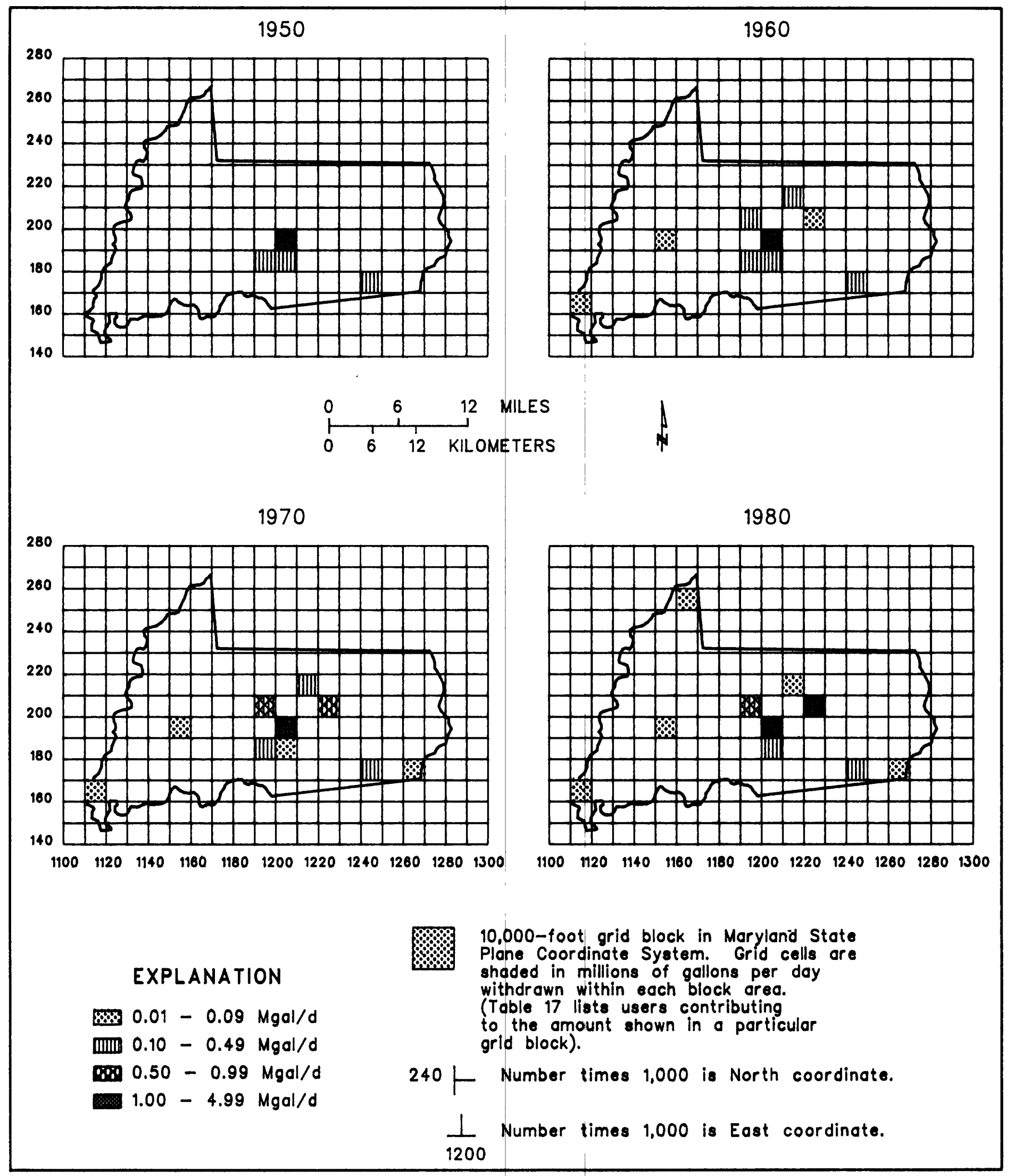

Figure 83.--Locations of large ground-water withdrawals in Wicomico County for 1950 , 1960,1970 , and 1980. 
Table 17.--Large ground-water users in Wicomico County in 1950, 1960, 1970, and 1980, summarized by the Maryland Grid Coordinate System

\begin{tabular}{|c|c|c|c|c|c|}
\hline Year & Grid & block & User & $\begin{array}{l}\text { Pumpage } \\
\text { (Mgal/d) }\end{array}$ & Aquifer \\
\hline 1950 & $\begin{array}{l}\text { N170 } \\
\text { N180 } \\
\text { N180 } \\
\text { N190 }\end{array}$ & $\begin{array}{l}\text { E1240 } \\
\text { E1190 } \\
\text { E1200 } \\
\text { E1200 }\end{array}$ & $\begin{array}{l}\text { Chesapeake Foods, Inc. } \\
\text { Green Giant Company } \\
\text { do. } \\
\text { Shoreland Freezers, Inc. } \\
\text { Messick Ice Company } \\
\text { Salisbury, City of }\end{array}$ & $\begin{array}{r}0.14 \\
.02 \\
.34 \\
.22 \\
.61 \\
2.30\end{array}$ & $\begin{array}{l}\text { Quaternary } \\
\text { Quaternary } \\
\text { Manokin } \\
\text { Quaternary } \\
\text { Quaternary } \\
\text { Quaternary }\end{array}$ \\
\hline 1960 & $\begin{array}{l}\text { N160 } \\
\text { N170 } \\
\text { N180 } \\
\text { N180 } \\
\text { N190 } \\
\text { N190 } \\
\text { N200 } \\
\text { N200 } \\
\text { N210 }\end{array}$ & $\begin{array}{l}\text { E1110 } \\
\text { E1240 } \\
\text { E1190 } \\
\text { E1200 } \\
\text { E1150 } \\
\text { E1200 } \\
\text { E1190 } \\
\text { E1220 } \\
\text { E1210 }\end{array}$ & $\begin{array}{l}\text { Champion Chick Products Corp. } \\
\text { Chesapeake Foods, Inc. } \\
\text { Green Giant Company } \\
\text { do. } \\
\text { Shoreland Freezers, Inc. } \\
\text { Poplar Hill Correction Camp } \\
\text { Messick Ice Company } \\
\text { Salisbury, City of } \\
\text { Campbell Soup, Inc. } \\
\text { A. W. Perdue \& Son, Inc. } \\
\text { Delmarva Power \& Light Company }\end{array}$ & $\begin{array}{r}0.01 \\
.25 \\
.02 \\
.34 \\
.27 \\
.02 \\
.77 \\
2.90 \\
.27 \\
.04 \\
.11\end{array}$ & $\begin{array}{l}\text { Manokin } \\
\text { Quaternary } \\
\text { Quaternary } \\
\text { Manokin } \\
\text { Quaternary } \\
\text { Manokin } \\
\text { Quaternary } \\
\text { Quaternary } \\
\text { Quaternary } \\
\text { Quaternary } \\
\text { Manokin }\end{array}$ \\
\hline 1970 & $\begin{array}{l}\text { N160 } \\
\text { N170 } \\
\text { N170 } \\
\text { N180 } \\
\text { N180 } \\
\text { N190 } \\
\text { N190 } \\
\text { N200 } \\
\text { N200 } \\
\text { N210 }\end{array}$ & $\begin{array}{l}\text { E1110 } \\
\text { E1240 } \\
\text { E1260 } \\
\text { E1190 } \\
\text { E1200 } \\
\text { E1150 } \\
\text { E1200 } \\
\text { E1190 } \\
\text { E1220 } \\
\text { E1210 }\end{array}$ & $\begin{array}{l}\text { Champion Chick Products Corp. } \\
\text { Chesapeake Growers, Inc. } \\
\text { Chesapeake Foods, Inc. } \\
\text { Shockley \& Son, Inc. } \\
\text { Green Giant Company } \\
\text { do. } \\
\text { Shoreland Freezers, Inc. } \\
\text { Poplar Hill Correction Camp } \\
\text { Messick Ice Company } \\
\text { Salisbury, City of } \\
\text { Campbell Soup, Inc. } \\
\text { A. W. Perdue \& Son, Inc. } \\
\text { Salisbury Mobile Home Park } \\
\text { Delmarva Power \& Light Company }\end{array}$ & $\begin{array}{r}0.01 \\
.02 \\
.19 \\
.02 \\
.02 \\
.34 \\
.10 \\
.02 \\
.77 \\
3.84 \\
.54 \\
.90 \\
.01 \\
.11\end{array}$ & $\begin{array}{l}\text { Manokin } \\
\text { Quaternary } \\
\text { Quaternary } \\
\text { Manokin } \\
\text { Quaternary } \\
\text { Manokin } \\
\text { Quaternary } \\
\text { Manokin } \\
\text { Quaternary } \\
\text { Quaternary } \\
\text { Quaternary } \\
\text { Quaternary } \\
\text { Quaternary } \\
\text { Manokin }\end{array}$ \\
\hline 1980 & $\begin{array}{l}\text { N160 } \\
\text { N170 } \\
\text { N170 } \\
\text { N180 } \\
\text { N190 } \\
\text { N190 } \\
\text { N200 } \\
\text { N200 } \\
\text { N210 } \\
\text { N250 }\end{array}$ & $\begin{array}{l}\text { E1110 } \\
\text { E1240 } \\
\text { E1260 } \\
\text { E1200 } \\
\text { E1150 } \\
\text { E1200 } \\
\text { E1190 } \\
\text { E1220 } \\
\text { E1210 } \\
\text { E1160 }\end{array}$ & $\begin{array}{l}\text { H. B. Kennerly \& Sons, Inc. } \\
\text { Chesapeake Growers, Inc. } \\
\text { Chesapeake Foods, Inc. } \\
\text { Shockley \& Son, Inc. } \\
\text { Shoreland Freezers, Inc. } \\
\text { Fruitland, City of } \\
\text { Poplar Hill Correction Camp } \\
\text { Messick Ice Company } \\
\text { Salisbury, City of } \\
\text { Campbell Soup, Inc. } \\
\text { A. W. Perdue \& Son, Inc. } \\
\text { Salisbury Mobile Home Park } \\
\text { Delmarva Power \& Light Company } \\
\text { Sharptown, City of }\end{array}$ & $\begin{array}{r}0.02 \\
.02 \\
.30 \\
.03 \\
.05 \\
.17 \\
.02 \\
.61 \\
3.87 \\
.86 \\
1.58 \\
.02 \\
.03 \\
.07\end{array}$ & $\begin{array}{l}\text { Manokin } \\
\text { Quaternary } \\
\text { Quaternary } \\
\text { Manokin } \\
\text { Quaternary } \\
\text { Quaternary } \\
\text { Manokin } \\
\text { Quaternary } \\
\text { Quaternary } \\
\text { Quaternary } \\
\text { Quaternary } \\
\text { Quaternary } \\
\text { Manokin } \\
\text { Quaternary }\end{array}$ \\
\hline
\end{tabular}


1950

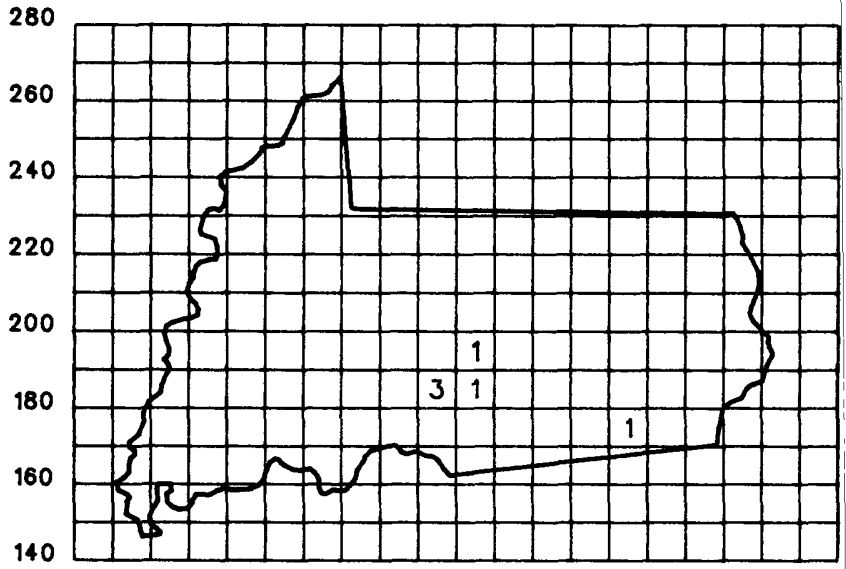

1960

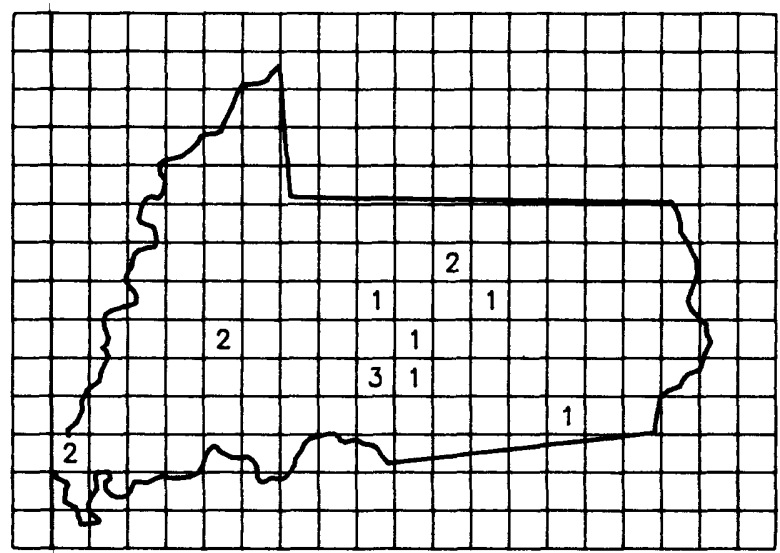

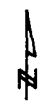

1970

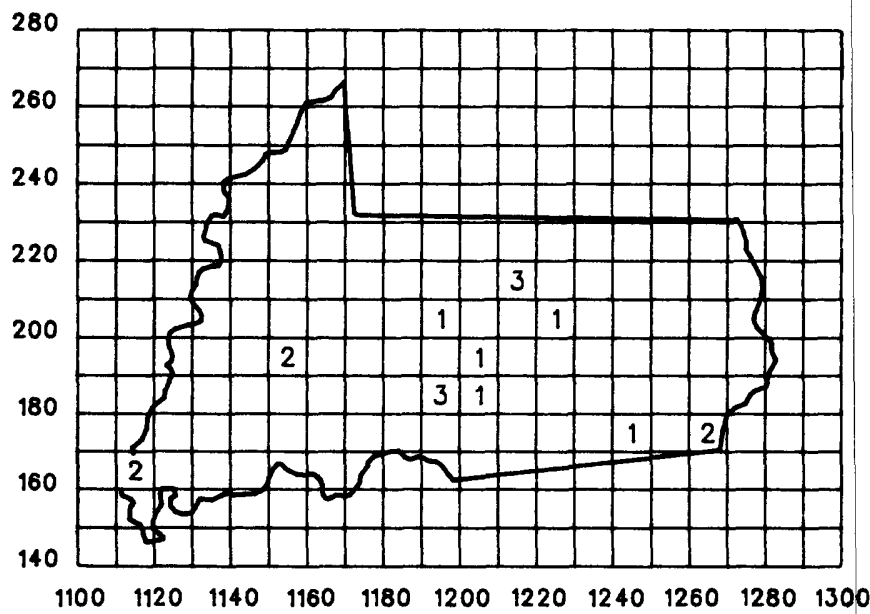

EXPLANATION

$1=$ Quoternary

$2=$ Manokin

3 = Quaternary \& Monokin
1980

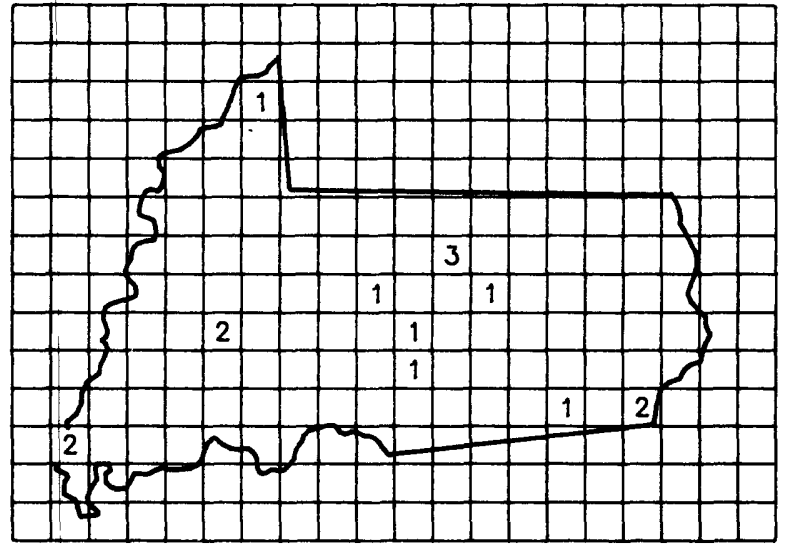

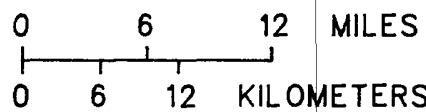

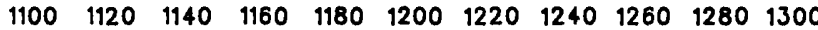

1 10,000-foot grid block in Maryland State

Plane Coordinate System. Numbers are

codes for the aquifer from which water is

withdrawn within a particular grid block.

$$
\begin{aligned}
& 240+\text { Number times } 1,000 \text { is North coordinate. } \\
& \frac{1}{1200} \text { Number times } 1,000 \text { is East coordinate. }
\end{aligned}
$$

Figure 84.--Locations of large ground-water withdrawals by aquifers in Wicomico County for 1950, 1960, 1970, and 1980. 


\section{WORCESTER COUNTY}

Ground-water use in Worcester County from 1950 through 1980 is shown in figure 85. In 1950, the amount of ground water withdrawn was approximately 4.5 $\mathrm{Mgal} / \mathrm{d}$ compared to withdrawals of nearly11 $\mathrm{Mgal} / \mathrm{d}$ in 1980. This represents an increase of 144 percent for the three decades.

Since 1950, ground-water use in Worcester County has increased in all categories. Domestic use was about $1.0 \mathrm{Mgal} / \mathrm{d}$ in 1950 , and, by 1980 , had increased to more than $2.0 \mathrm{Mgal} / \mathrm{d}$. Withdrawals by water suppliers increased from approximately $1.4 \mathrm{Mgal} / \mathrm{d}$ in 1950 to about $5.0 \mathrm{Mgal} / \mathrm{d}$ in 1980 . Industrial/ commercial use increased from about $3.8 \mathrm{Mgal} / \mathrm{d}$ in 1970 to $5.8 \mathrm{Mgal} / \mathrm{d}$ in 1975 , and dropped to about $3.0 \mathrm{Mgal} / \mathrm{d}$ in 1980 . Withdrawals for agricultural irrigation were about 0.16 $\mathrm{Mgal} / \mathrm{d}$ in 1960 , but increased to $0.68 \mathrm{Mgal} / \mathrm{d}$ by 1980 . See appendix for ground-water withdrawal data for each large user: User's name, appropriation permit number, source aquifer, location on the Maryland Grid Coordinate System, average daily pumpage, and year pumping began.

The percentages of the total amount of ground water withdrawn for domestic, water supplier, industrial/commercial, and irrigation uses are shown in figure 86. The percentage for domestic use remained relatively the same for the 4 years shown. The percentage for water suppliers was about the same in 1950 (32 percent) and 1960 (about 30 percent), increasing a small amount in 1970 (35 percent). By 1980, it had increased to 46.6 percent of the total. Industrial/commercial use comprised a significant portion of the total pumpage (about 50 percent) for the years 1950 and 1960. By 1980 , however, the representative percentage for this use had dropped to 27 percent.

\section{Major Aquifers}

The earliest ground-water pumpage in Worcester County probably came from the surficial (Quaternary) aquifer. These shallow sands continued to supply much of the low-yield water needs, chiefly for domestic use, although some large users also were able to withdraw sufficient quantities of water from the surficial aquifer. However, as the demand for water increased, use of the deeper Manokin and Pocomoke (in the upper Chesapeake Group) aquifers increased.

Large user withdrawals by aquifer in the county from 1950 through 1980 are shown in figure 87. In 1950 about $1.0 \mathrm{Mgal} / \mathrm{d}$ was withdrawn from the surficial aquifer. Pumpage gradually increased to about 4.3 Mgal/d in 1975 before declining to approximately 3.0 $\mathrm{Mgal} / \mathrm{d}$ in 1980 . The largest amount of water for the 30-year period was withdrawn from the Manokin and Pocomoke aquifers. In 1950 , about $1.2 \mathrm{Mgal} / \mathrm{d}$ was withdrawn. By 1976 , more than $5.6 \mathrm{Mgal} / \mathrm{d}$ was pumped from the Manokin and Pocomoke; withdrawals declined to about $4.9 \mathrm{Mgal} / \mathrm{d}$ in 1980 .

\section{Locations of Large Ground-Water Withdrawals}

The locations of withdrawals by large users in Worcester County for 1950, 1960,1970, and 1980 are shown in figure 88. Table 18 presents water-use data for the large users located within particular grid blocks for the year indicated on the map. The maps indicate that the areal distribution of pumpage was similar for the years shown; however, the largest withdrawals were located mostly in the northeastern (Ocean City area) and southwestern sections of the county.

The locations of withdrawals from individual aquifers supplying the large users in Worcester County (described in table 18 and fig. 88) are shown in figure 89. From 1950 through 1980, large withdrawals from the surficial aquifer occurred primarily in the northern part of the county, although use of the Manokin and Pocomoke aquifers was more extensive.

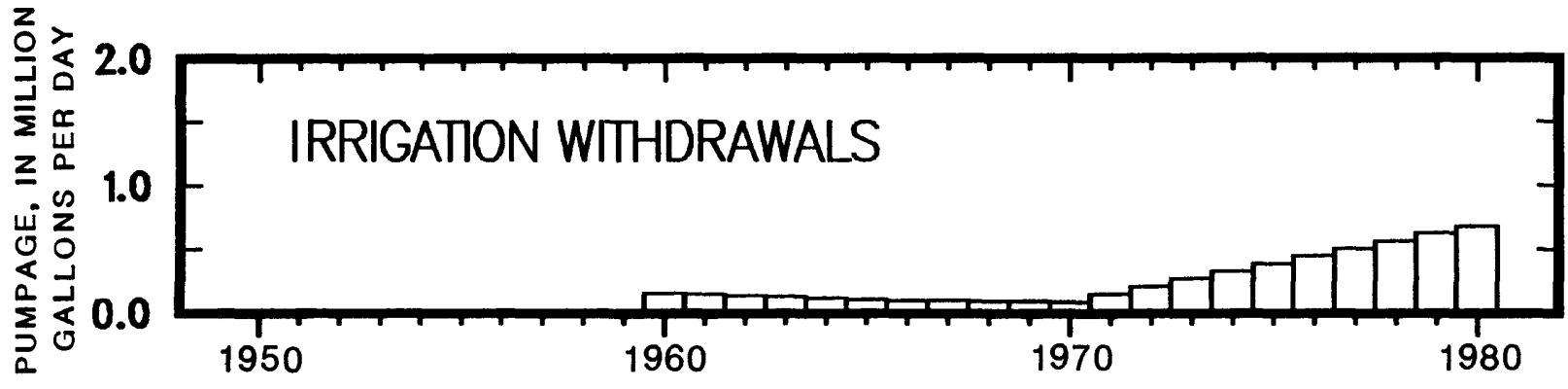

Figure 85.--Ground-water withdrawals by use in Worcester County from 1950 through 1980. 


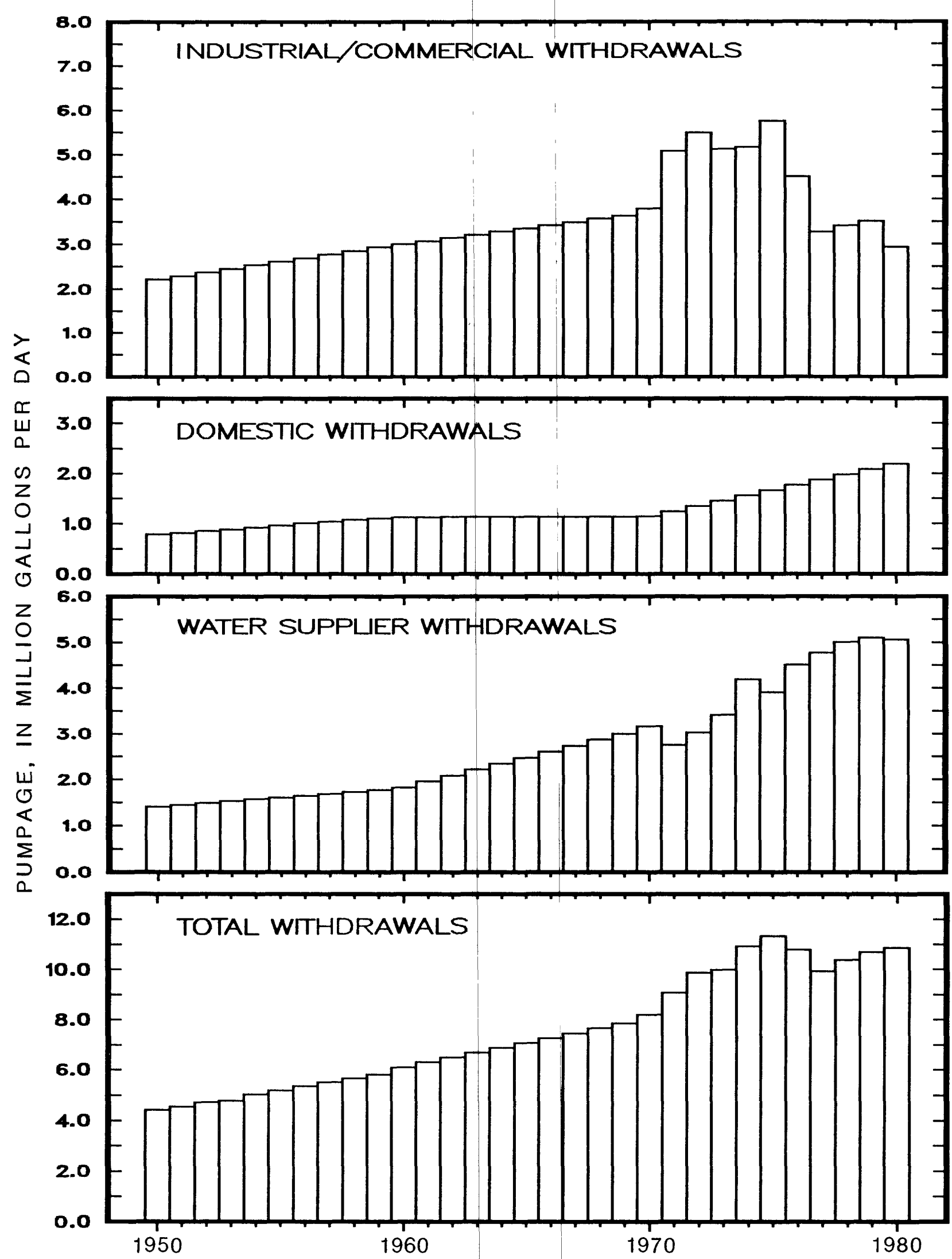

Figure 85.--Ground-water withdrawals by use in Worcester County from 1950 through 1980--Continued. 


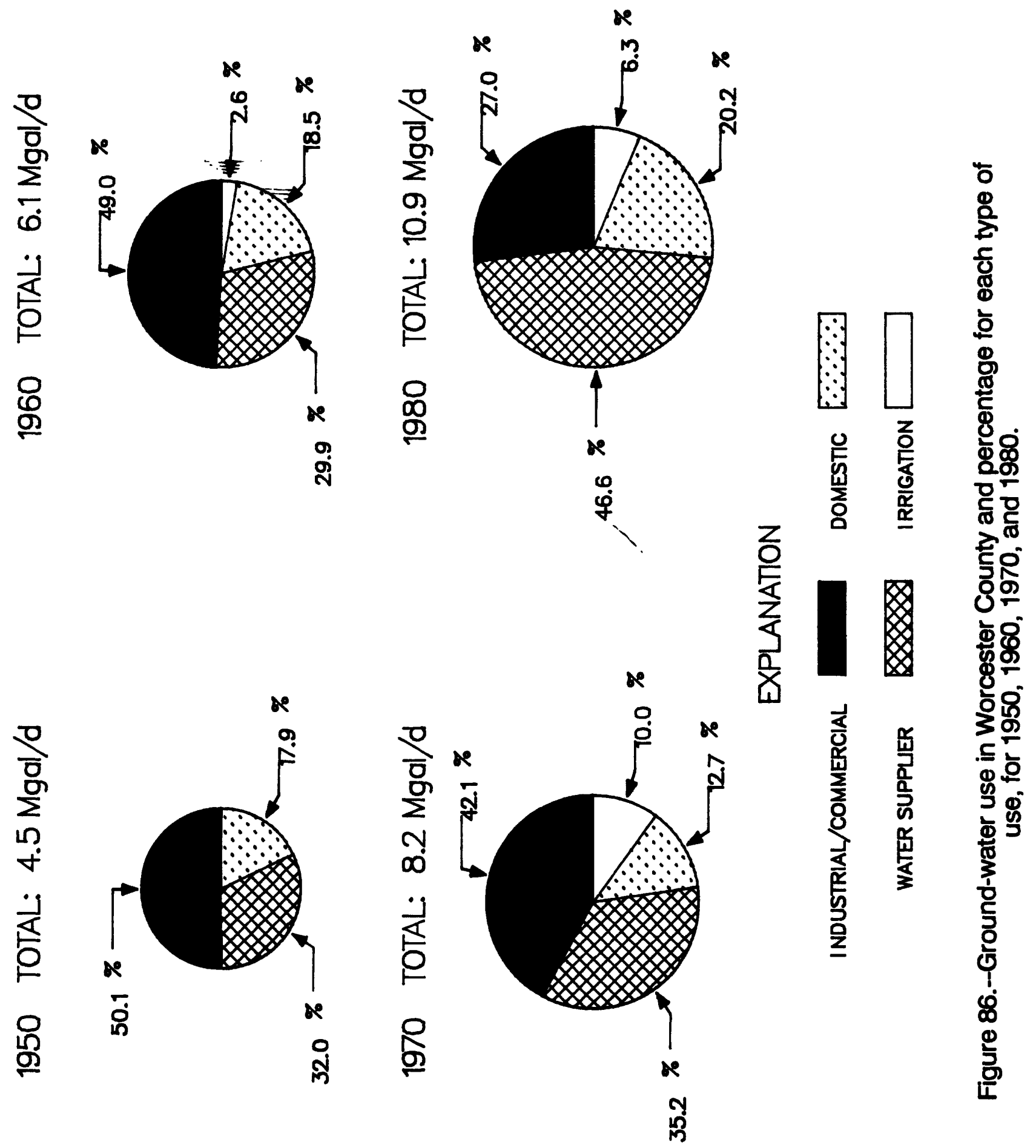




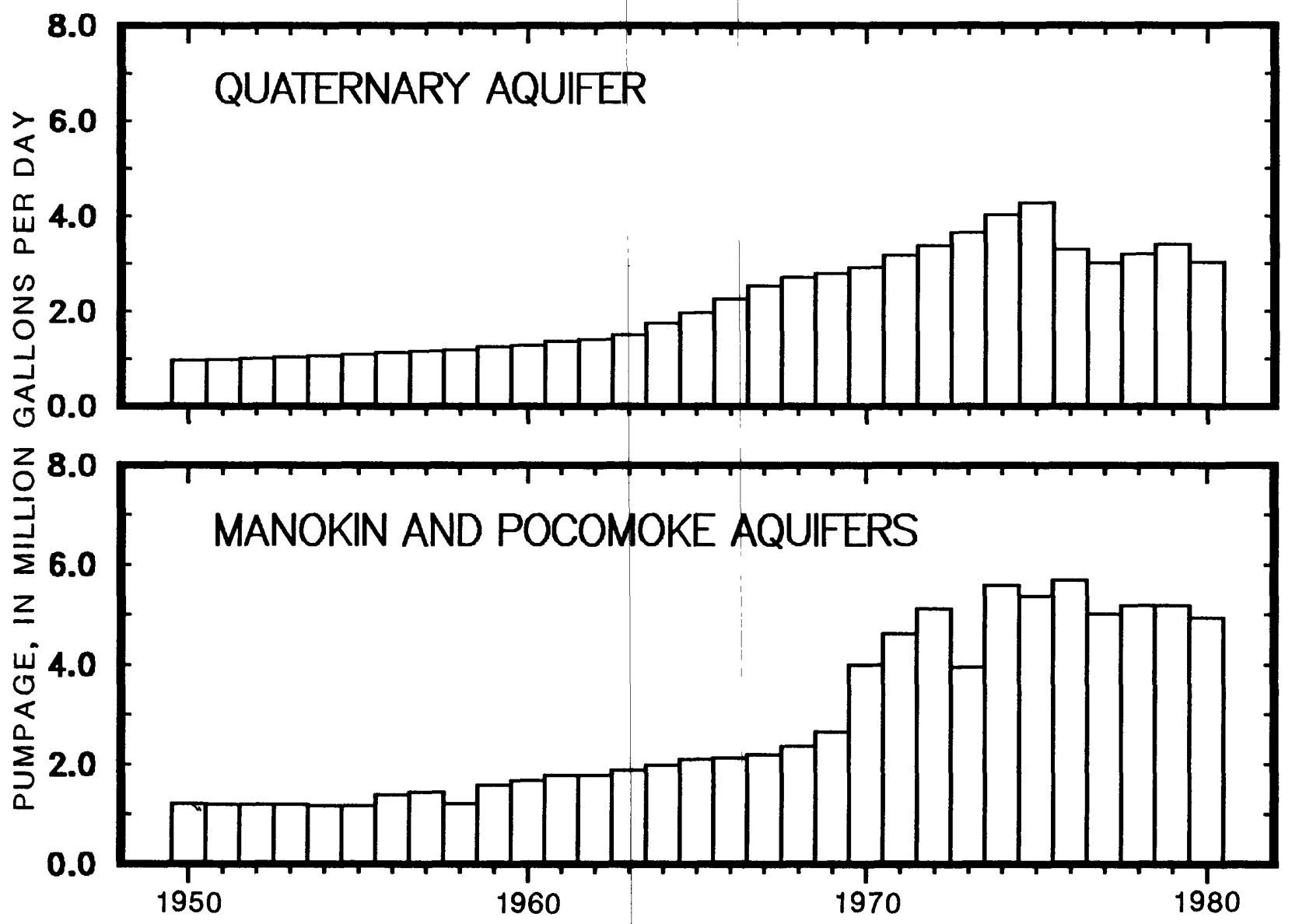

Figure 87.--Large ground-water withdrawals by aquifers in Worcester County from 1950 through 1980. 
1950

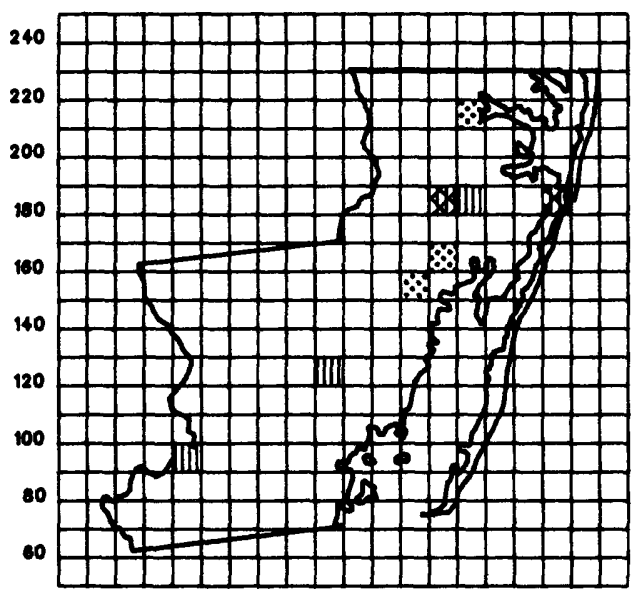

1960

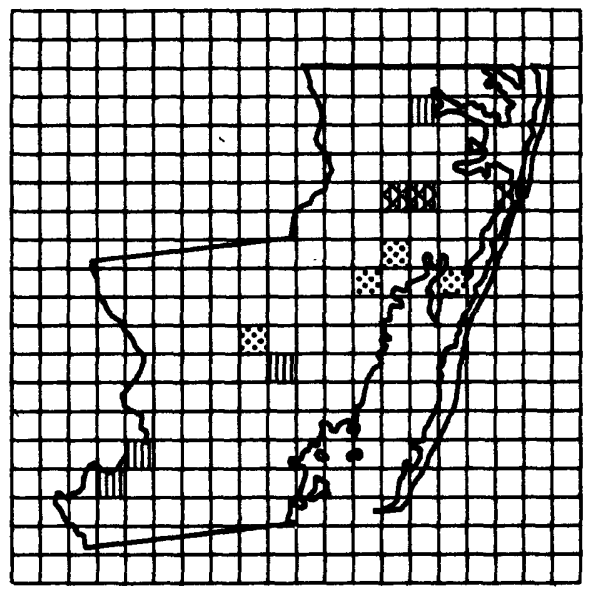

$\downarrow$

1980

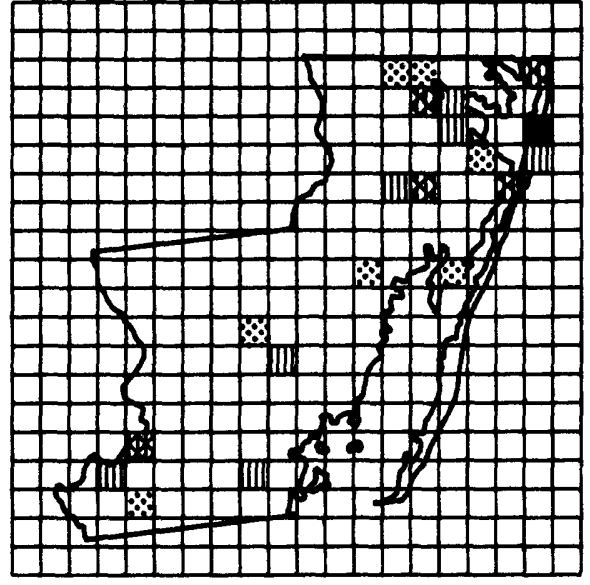

$12801200 \quad 12201240 \quad 1210 \quad 1210 \quad 1300 \quad 2320 \quad 1340 \quad 1360$

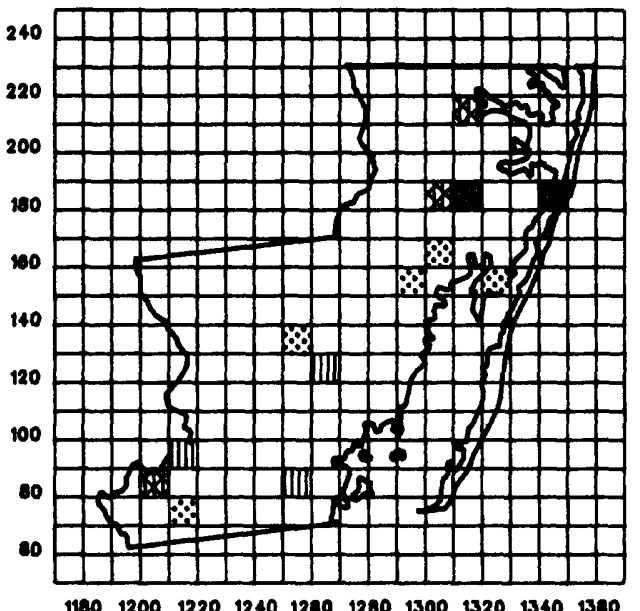

\section{EXPLANATION}

$0.01-0.09 \mathrm{Mgal} / \mathrm{d}$

․ㅔIm $0.10-0.49 \mathrm{Mgal} / \mathrm{d}$

$0.50-0.99 \mathrm{Mgal} / \mathrm{d}$

$1.00-4.99 \mathrm{Mgol} / \mathrm{d}$
10,000 -foot grid block in Maryland State Plane Coordinate System. Grid cells are shaded in millions of gollons per day withdrawn within each block orea.

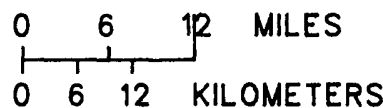

Table 18 lists users contributing

to the amount shown in a particular grid block).

180

- Number times 1,000 is North coordinate.

Number times 1,000 is Eost coordinate.

Figure 88.--Locations of large ground-water withdrawals in Worcester County for 1950 , 1960,1970 , and 1980. 
Table 18.--Large ground-water users in Worcester County in 1950, 1960, 1970, and 1980, sumarized by the Maryland Grid Coordinate System

\begin{tabular}{|c|c|c|c|c|c|}
\hline Year & Grid block & User & & $\begin{array}{l}\text { Pumpase } \\
\text { (Msal/d) }\end{array}$ & Aquifer \\
\hline 1950 & $\begin{array}{ll}N 90 & E 1210 \\
N 130 & E 1260 \\
N 150 & E 1290 \\
N 160 & E 1300 \\
N 180 & E 1300 \\
N 180 & E 1310 \\
N 180 & E 1340 \\
N 210 & E 1310\end{array}$ & $\begin{array}{l}\text { Pocomoke City } \\
\text { Snow Bill, Town of } \\
\text { Mason Canning Company } \\
\text { do. } \\
\text { Davis Ice, Inc. } \\
\text { Berlin, City of } \\
\text { Savage Ice Company } \\
\text { Ocean City } \\
\text { Showell Farms, Inc. }\end{array}$ & & $\begin{array}{r}0.45 \\
.26 \\
.01 \\
.03 \\
.63 \\
.11 \\
.03 \\
.59 \\
.07\end{array}$ & $\begin{array}{l}\text { Pocomoke } \\
\text { Manokin } \\
\text { Pocomoke } \\
\text { Quaternary } \\
\text { Quaternary } \\
\text { Quaternary } \\
\text { Quaternary } \\
\text { Manokin } \\
\text { Quaternary }\end{array}$ \\
\hline 1960 & 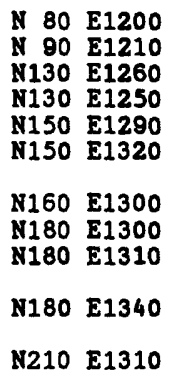 & $\begin{array}{l}\text { Campbel1 Soup Company } \\
\text { Pocomoke, City of } \\
\text { Snow Bili, Town of } \\
\text { Holly Farms, Inc. } \\
\text { Mason Canning Company } \\
\text { Ocean City Golf \& Yacht } \\
\text { do.. } \\
\text { Mason Canning Company } \\
\text { Davis Ice, Inc. } \\
\text { Berlin, City of } \\
\text { Chesapeake Foods } \\
\text { Savage Ice Company } \\
\text { Ocean City } \\
\text { Showell Farms, Inc. }\end{array}$ & Club, Ind. & $\begin{array}{l}0.16 \\
.33 \\
.26 \\
.01 \\
.01 \\
.01 \\
.01 \\
.03 \\
.66 \\
.19 \\
.36 \\
.05 \\
.71 \\
.14\end{array}$ & $\begin{array}{l}\text { Pocomoke } \\
\text { Pocomoke } \\
\text { Manokin } \\
\text { Manokin } \\
\text { Pocomoke } \\
\text { Pocomoke } \\
\text { Quaternary } \\
\text { Quaternary } \\
\text { Quaternary } \\
\text { Quaternary } \\
\text { Pocomoke } \\
\text { Quaternary } \\
\text { Manokin } \\
\text { Quaternary }\end{array}$ \\
\hline 1970 & 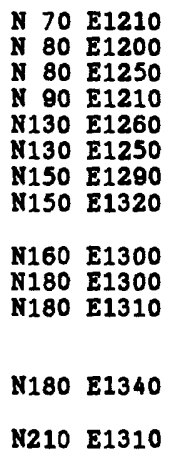 & $\begin{array}{l}\text { Quality Inn } \\
\text { Campbell Soup Company } \\
\text { Perdue, Inc. } \\
\text { Pocomoke City } \\
\text { Snow Hill, Town of } \\
\text { Holly Farms, Inc. } \\
\text { Mason Canning Company } \\
\text { Ocean City Golf \& Yacht } \\
\text { do. } \\
\text { Mason Canning Company } \\
\text { Davis Ice, Inc. } \\
\text { Ross Wells, Inc. } \\
\text { Berlin, City of } \\
\text { Chesapeake Foods } \\
\text { Sevage Ice Company } \\
\text { Ocean City } \\
\text { Showell Farms, Inc. }\end{array}$ & Club, Inc. & $\begin{array}{l}0.02 \\
.85 \\
.41 \\
.30 \\
.26 \\
.02 \\
.02 \\
.02 \\
.02 \\
.03 \\
.68 \\
.02 \\
.41 \\
.71 \\
.06 \\
2.19 \\
.82\end{array}$ & $\begin{array}{l}\text { Pocomoke } \\
\text { Pocomoke } \\
\text { Quaternary } \\
\text { Pocomoke } \\
\text { Manokin } \\
\text { Manokin } \\
\text { Pocomoke } \\
\text { Pocomoke } \\
\text { Quaternary } \\
\text { Quaternary } \\
\text { Quaternary } \\
\text { Quaternary } \\
\text { Quaternary } \\
\text { Pocomoke } \\
\text { Quaternary } \\
\text { Manokin } \\
\text { Quaternary }\end{array}$ \\
\hline 1980 & 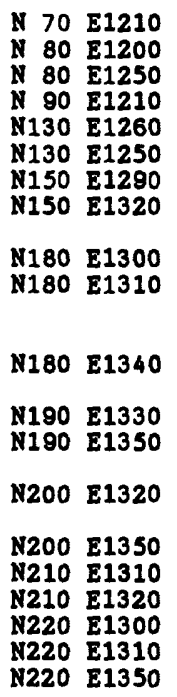 & 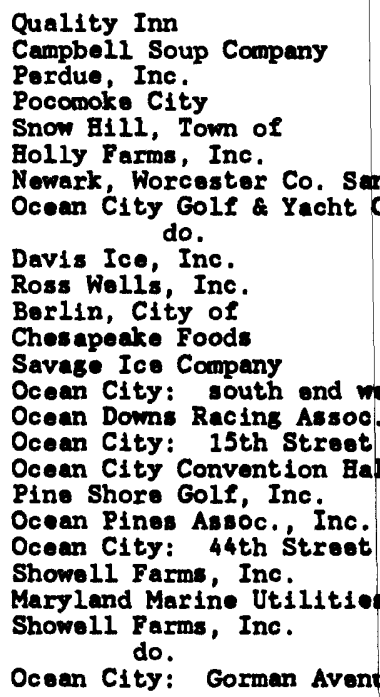 & \begin{tabular}{|l} 
Club, Inc. \\
Citary Comm. \\
Inc. \\
wells \\
wells \\
Inc.
\end{tabular} & $\begin{array}{l}0.01 \\
.32 \\
.46 \\
.57 \\
.34 \\
.03 \\
.01 \\
.02 \\
.02 \\
.29 \\
.01 \\
.41 \\
.37 \\
.04 \\
.90 \\
.05 \\
.40 \\
.02 \\
.05 \\
.11 \\
1.34 \\
.88 \\
.25 \\
.01 \\
.08 \\
.97\end{array}$ & $\begin{array}{l}\text { Pocomoke } \\
\text { Pocomoke } \\
\text { Quaternary } \\
\text { Pocomoke } \\
\text { Manokin } \\
\text { Manokin } \\
\text { Pocomoke } \\
\text { Pocomoke } \\
\text { Quaternary } \\
\text { Quaternary } \\
\text { Quaternary } \\
\text { Quaternary } \\
\text { Pocomoke } \\
\text { Pocomoke } \\
\text { Manokin } \\
\text { Quaternary } \\
\text { Manokin } \\
\text { Manokin } \\
\text { Quaternary } \\
\text { Quaternary } \\
\text { Manokin } \\
\text { Quaternary } \\
\text { Quaternary } \\
\text { Quaternary } \\
\text { Quaternary } \\
\text { Manokin }\end{array}$ \\
\hline
\end{tabular}


1950

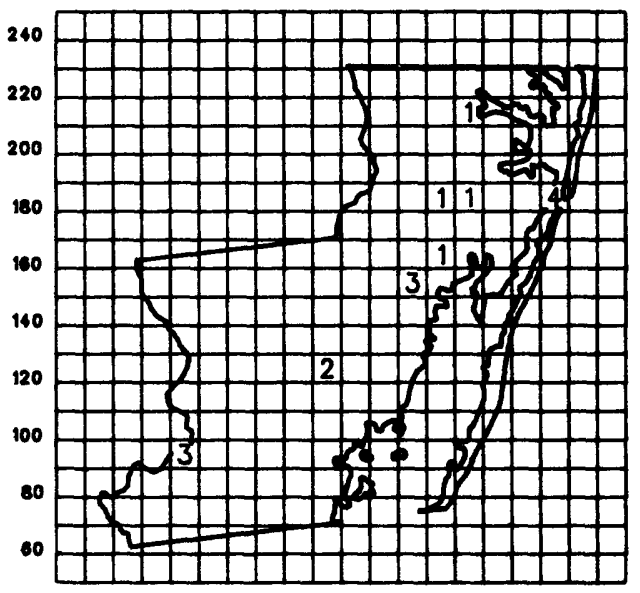

1960

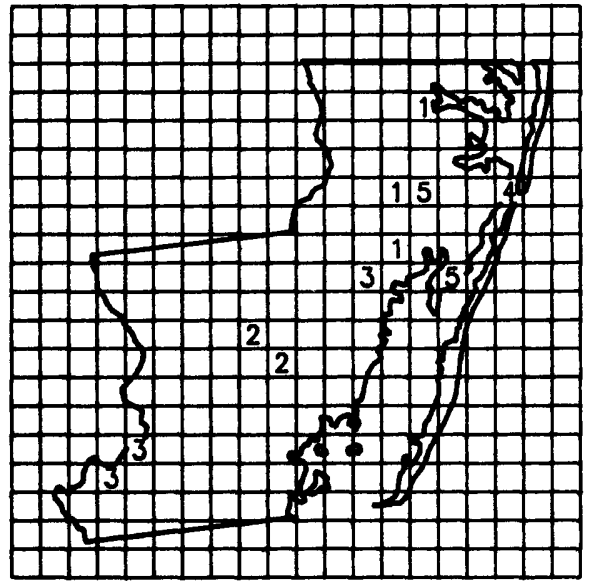

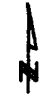

1980

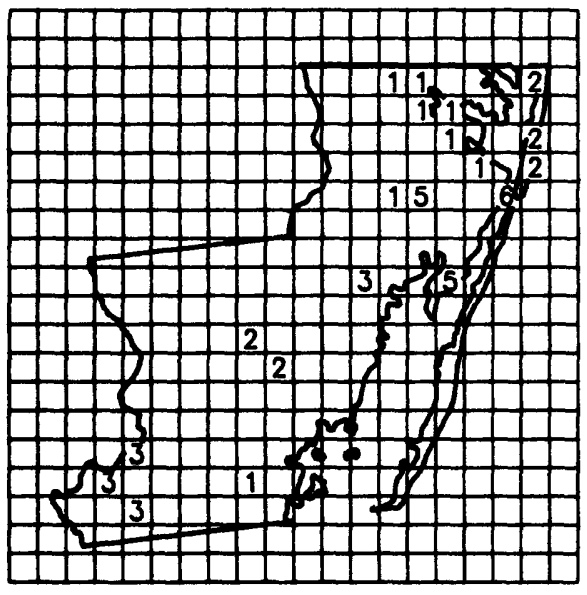

$1300120012201240 \quad 1280 \quad 1280 \quad 1300 \quad 1320 \quad 1340 \quad 2380$

\section{EXPLANATION}

1 = Quaternary

$2=$ Manokin

3 = Pocomoke

4 = Quaternary \& Manokin

5 = Quaternary \& Pocomoke

$6=$ Manokin \& Pocomoke

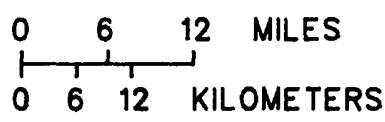

1970

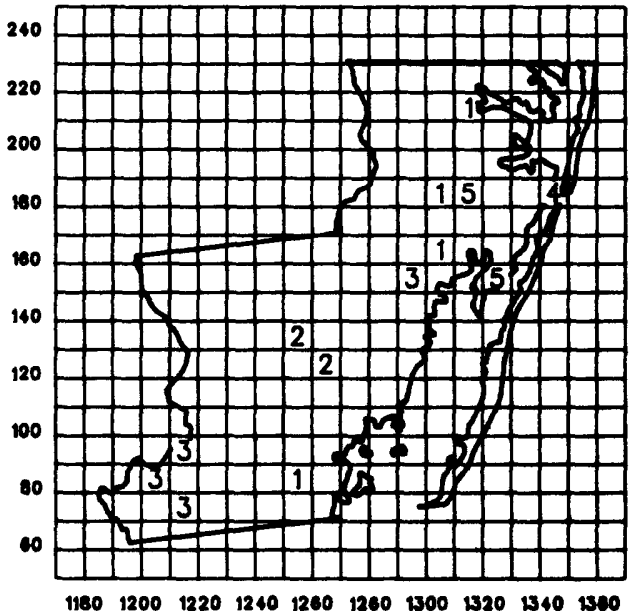

10,000-foot grid block in Maryland State Plane Coordinate System. Numbers are codes for the aquifer from which woter is withdrawn within a particular grid block.

Number times 1,000 is North coordinote.

Number times 1,000 is East coordinate.

Figure 89.--Locations of large ground-water withdrawals by aquifers in Worcester County for 1950, 1960, 1970, and 1980. 


\section{SUMMARY}

Ground water was the major source of supply for most water users in the Coastal Plain of Maryland from 1900 through 1980. Withdrawals from Baltimore City and the 16 counties included in this report that lie either partially or totally within the Coastal Plain increased from approximately $25 \mathrm{Mgal} / \mathrm{d}$ in 1900 to nearly 136 $\mathrm{Mgal} / \mathrm{d}$ in 1980. The jurisdictions with the greatest withdrawals (more than $5 \mathrm{Mgal} / \mathrm{d}$ for most of the 80-year period) were Anne Arundel and Baltimore Counties and Baltimore City.

The major uses of ground water were domestic, military, water suppliers, industrial/commercial, and irrigation. Domestic and industrial/commercial uses comprised the largest withdrawals from 1900 through
1965. For most of the next 15 years, water suppliers constituted the greatest use of ground water.

Large withdrawals for irrigation in the Coastal Plain began in the late 1950 's and were primarily centered in Caroline, Dorchester, Queen Annes, and Wicomico Counties.

The surficial (Quaternary) aquifer was a primary source of water supply for many domestic withdrawals, and also provided adequate quantities to some large users (withdrawing $0.01 \mathrm{Mgal} / \mathrm{d}$ or more). However, the deeper Patapsco and Patuxent aquifers supplied the most water to large users during the $\mathbf{8 0}$ year period, mainly for industrial/commercial use. 


\section{SELECTED REFERENCES}

Anne Arundel County Commissioners, 1979, Anne Arundel County master plan for water supply and sewerage systems, 1980-1999: Consultant's report done by Whitman, Requardt, and Associates for Anne Arundel County, Baltimore, Maryland, $158 \mathrm{p}$.

Baltimore City Department of Public Works, 1970, Story of Baltimore's water supply: Baltimore City Department of Public Works, Baltimore, Maryland, $32 \mathrm{p}$.

Baltimore City Department of Public Works, 1977, City of Baltimore comprehensive water and waste water plan: Baltimore City Department of Public Works, Baltimore, Maryland, $79 \mathrm{p}$.

Baltimore County Department of Public Works, 1970, Baltimore County comprehensive water and sewage plan: Baltimore County Department of Public Works, Towson, Maryland, $41 \mathrm{p}$.

Bennett, R. R., and Collins, G.G., 1952, Brightseat Formation, a new name for sediments of Paleocene age in Maryland: Washington Academy of Science Journal, v. 42, p. 114-116.

Bennett, R. R. and Meyer, R. R., 1952, Geology and ground-water resources of the Baltimore area: Maryland Geological Survey, Bulletin 4, 573 p.

Bennion, V. R. and Brookhart, J. W., 1949, Water resources of Anne Arundel County: Maryland Geological Survey, Bulletin 5, 149 p.

Bennion, V. R., Dougherty, D. F., and Overbeck, R. M., 1951, Water resources of Calvert County: Maryland Geological Survey, Bulletin 8, 100 p.

Brodie, H. L., Carr, L. E., Russek, Estelle, and Stewart, L. E., 1984, A survey of agricultural irrigation in Maryland -- 1982: University of Maryland, Cooperative Extension Service, College Park, Maryland, 51 p.

Calvert County Department of Planning and Zoning, 1979, Calvert County comprehensive water and sewerage plan: Calvert County Department of Planning and Zoning, Prince Frederick, Maryland, 98 p.

Caroline County Commissioners, 1970, Caroline County comprehensive water and sewerage plan: Caroline County Commissioners, Denton, Maryland, 100 p.
Carr, L. E., 1975, The 1975 irrigation survey summary: University of Maryland, College Park, Maryland, 4 p.

1977, The 1977 Maryland irrigation survey: University of Maryland, College Park, Maryland, $6 \mathrm{p}$.

1980, The 1980 Maryland irrigation survey: University of Maryland, College Park, Maryland, $7 \mathrm{p}$.

Cecil County Commissioners, 1974, Cecil County comprehensive water and sewerage plan: Cecil County Commissioners, Elkton, Maryland, 127 p.

Charles County Commissioners, 1977, Charles County comprehensive water and sewerage plan: Resources Management Associates, Inc., Consultant's report for Charles County Commissioners, Glen Burnie, Maryland, $145 \mathrm{p}$.

Cleaves, E. T., Edwards, Jonathan, Jr., and Glaser, J. D., 1968, Geologic map of Maryland: Maryland Geological Survey, scale: 1:250,000, 1 sheet.

Cushing, E. M., Kantrowitz, I. H., and Taylor, K. R., 1973, Water resources of the Delmarva Peninsula: U.S. Geological Survey Professional Paper 822, 58 p.

Dingman, R. J., Ferguson, H. F., and Martin, R. O. R., 1954, Water resources of Baltimore and Harford Counties: Maryland Geological Survey, Bulletin 17, $233 \mathrm{p}$.

Dorchester County Commissioners, 1974, Dorchester County comprehensive water and sewerage plan: County Commissioners of Dorchester County, Cambridge, Maryland, $125 \mathrm{p}$.

Geyer, J. C., 1945, Ground water in the Baltimore industrial area: Maryland State Planning Commission, Baltimore, Maryland, no. 44, 299 p.

Hansen, H. J., 1967, Hydrogeologic data from the Janes Island State Park test well (1,514 feet), Somerset County, Maryland: Maryland Geological Survey, Basic-Data Report No. 3, 24 p.

Hansen, H. J., and Wilson, J. M., 1984, Summary of hydrogeologic data from a deep well (2,678 feet) at Lexington Park, St. Marys County, Maryland: Maryland Geological Survey, Open File Report No. 84-02-01, 61p. 
Harford County Council, 1970, Harford County comprehensive sewer and water plan: County Council of Harford County, Bel Air, Maryland, 65 p.

Herring, J. R., 1983, Maryland water withdrawal and use report, 1980: Maryland Department of Natural Resources, Annapolis, Maryland, 45 p.

Herring, J. R. and Miller, K. M., 1981, Maryland water use report, 1979: Maryland Department of Natural Resources, Annapolis, Maryland, $28 \mathrm{p}$.

Kent County Planning Commission, 1970, Kent County comprehensive water and sewerage plan: Kent County Planning Commission, Chestertown, Maryland, $42 \mathrm{p}$.

Knopf, E. B., 1929, The physiography of Baltimore County, in Maryland Geological Survey County Report, Baltimore County: Johns Hopkins Press, Baltimore, Maryland, p. 58-93.

Lohman, S. W., and others, 1972, Definitions of selected ground-water terms--Revisions and conceptual refinements: U.S. Geological Survey Water-Supply Paper 1988, 21 p.

Mack, F. K., 1966, Ground water in Prince Georges Ccunty: Maryland Geological Survey, Bulletin 29, 10 i p.

Mack, F. K. and Richardson, C. A., 1962, Ground-water supplies for industrial and urban development in Anne Arundel County: Maryland Geological Survey, Bulletin 26, $90 \mathrm{p}$.

Mack, F. K., Wheeler, J. C., and Curtin, S. E., 1982, Water-level declines in the Magothy aquifer in southern Maryland related to increases in pumpage: U.S. Geological Survey Open-File Report 82-919, $44 \mathrm{p}$.

Martin, R. O. R. and Ferguson, H. F., 1952, Geology and water resources of Prince Georges County: Maryland Geological Survey, Bulletin 10, 270 p.

1953, Water resources of St. Marys County: Maryland Geological Survey, Bulletin 11, 195 p.

Maryland Department of Natural Resources, 1983, Water supplies of Maryland, the status of water supply development and potential water problems in Maryland: Maryland Department of Natural Resources, Annapolis, Maryland, v. 4, 96 p.

Maryland Department of State Planning, 1978, Manual of coordinates of Maryland: Maryland Department of State Planning, Baltimore, Maryland, 205 p.
Maryland Department of State Planning, 1981, Maryland population data; state, county, minor civil division, and municipal trends through 1980: Maryland Department of State Planning, Baltimore, Maryland, 253 p.

Otton, E. G., 1955, Ground-water resources of the southern Maryland Coastal Plain: Maryland Geological Survey, Bulletin 15, 347 p.

Otton, E. G., Martin, R. O. R., and Durum, W. H., 1964, Water resources of the Baltimore area, Maryland: U.S. Geological Survey Water-Supply Paper 1499F, 105 p.

Overbeck, R. M., Slaughter, T. H., and Hulme, A. E., 1958, Water resources of Cecil, Kent, and Queen Annes Counties: Maryland Geological Survey, Bulletin 21, $478 \mathrm{p}$.

Prince Georges County Council, 1966, Prince Georges County master water and sewerage plan: Prince Georges County Council, Upper Marlboro, Maryland, $135 \mathrm{p}$.

Queen Annes County Commissioners, 1977, Queen Annes County master water and sewerage plan: Queen Annes County Commissioners, Centreville, Maryland, $160 \mathrm{p}$.

Rasmussen, W. C., and Slaughter, T. H., 1955, Water resources of Somerset, Wicomico, and Worcester Counties: Maryland Geological Survey, Bulletin 16, $535 \mathrm{p}$.

1956, Water resources of Caroline, Dorchester, and Talbot Counties: Maryland Geological Survey, Bulletin 18, $465 \mathrm{p}$.

Slaughter, T. H., Otton, E. G., and Laughlin, C. P., 1968, Availability of ground water in Charles County: Maryland Geological Survey, Bulletin 30, 101 p.

St. Marys County Office of Land Use and Development, 1978, St. Marys County comprehensive water and sewerage plan: St. Marys County Office of Land Use and Development, Leonardtown, Maryland, $145 \mathrm{p}$.

Sohl, N. F., and Wright, W. B., 1977, Changes in stratigraphic nomenclature by the U.S. Geological Survey: U.S. Geological Survey Bulletin 1435-A, p. A132-A133.

Somerset County Board of County Commissioners, 1967, Somerset County comprehensive water and sewerage plan: Somerset County Board of County Commissioners, Princess Anne, Maryland, 121 p. 
Talbot County Council, 1969, Talbot County comprehensive water and sewerage plan: Talbot County Council, Easton, Maryland, 39 p.

Tompkins, M. D., 1983, Prince Georges County groundwater information-- well records, chemical-quality data, pumpage, appropriation data, observation well records, and well logs: Maryland Geological Survey, Basic-Data Report No. 13, 160 p.

U.S. Department of Commerce, 1961, Census of agriculture, 1959: U.S. Bureau of the Census, U.S. Government Printing Office, Washington, D.C., v. 1, part 23, 167 p.

1967, Census of agriculture, 1964: U.S. Bureau of the Census, U.S. Government Printing Office, Washington, D.C., v. 1, part 23, 285 p.

1972, Census of agriculture, 1969: U.S. Bureau of the Census, U.S. Government Printing Office, Washington, D.C., v. 1, part 23, 285 p.

1977, Census of agriculture, 1974: U.S. Bureau of the Census, U.S. Government Printing Office, Washington, D.C., v. 1, part 20, 214 p.

1981a, Census of agriculture, 1978: U.S. Bureau of the Census, U.S. Government Printing Office, Washington, D.C., v. 1, part 20, 214 p.

1981b, Census of population and housing, final population and housing units counts, Maryland: U.S. Bureau of the Census, U.S. Government Printing Office, Washington, D.C., 12 p.
U.S. Environmental Protection Agency, 1973, Manual of individual water supply systems: U.S. Government Printing Office, Washington, D.C., 155 p.

Vokes, H. E., 1957, Geography and geology of Maryland: Maryland Geological Survey, Bulletin 19, 242 p.

Ward, L. W., 1985, Stratigraphy and characteristic mollusks of the Pamunkey Group (lower Tertiary) and the Old Church Formation of the Chesapeake Group--Virginia Coastal Plain: U.S. Geological Survey Professional Paper, $78 \mathrm{p}$.

Ward, L. W., and Blackwelder, B. W., 1980, Stratigraphic revision of upper Miocene and lower Pliocene beds of the Chesapeake Group, Middle Atlantic Coastal Plain: U.S. Geological Survey Bulletin 1482-D, p. D1-D61.

Wicomico County Department of Public Works, 1969, Wicomico County comprehensive water and sewerage plan: Wicomico County Department of Public Works, Salisbury, Maryland, 134 p.

Worcester County Commissioners, 1969, Worcester County comprehensive plan for water and sewerage systems: Consultant's report by George, Miles, and Buhr for Worcester County Commissioners, Salisbury, Maryland, 118 p. 
APPENDIX 
Ground-water withdrawals by laxge users in Ame Arundel Counts. 1900 throhgh 1980

(Sources: Maryland Water Resources Administration files, Maryland Geological Survey reports, county water and sewerage plans, and miscellaneous county reports)

\begin{tabular}{|c|c|c|c|c|c|c|c|c|c|}
\hline User & $\begin{array}{l}\text { Appropriation } \\
\text { number }\end{array}$ & Aquifer & $\begin{array}{l}\text { Maryland } 8 \\
\text { coordinat }\end{array}$ & tes & 1980 & 1979 & 1978 & 1977 & 1976 \\
\hline Annapolis, City of & $72-009$ & Magothy & $\begin{array}{l}\text { N421 } \\
\text { E924 }\end{array}$ & & 3.285 & 3.233 & 3.173 & 2.992 & 2.739 \\
\hline Annapolis, City of & 72-009 & Patapsco & $\begin{array}{l}\text { K421 } \\
\mathbf{E} 924\end{array}$ & & 1.396 & 1.315 & .511 & .795 & .838 \\
\hline $\begin{array}{l}\text { Annapolis Landing Water Treatment } \\
\text { Plant }\end{array}$ & 77-048 & Magothy & $\begin{array}{l}\text { K405 } \\
\mathbf{E} 918\end{array}$ & & .033 & .007 & .008 & .007 & .007 \\
\hline Annapoli: Terrace Motel & $56-011$ & Aquia & $\begin{array}{l}\text { N432 } \\
\mathrm{E} 947\end{array}$ & & .010 & .010 & .010 & .010 & .010 \\
\hline Bodkin Elementary School & $70-013$ & Patapsco & $\begin{array}{l}\text { N465 } \\
\mathbf{E} 950\end{array}$ & t & .012 & .012 & .012 & .012 & .004 \\
\hline Boones Mobile Estates & $76-014$ & Magothy & $\begin{array}{l}\text { N355 } \\
\text { E890 }\end{array}$ & & .022 & .024 & .021 & .019 & .000 \\
\hline $\begin{array}{l}\text { Broad Creek, Anne Arundel County } \\
\text { Department of Utilities }\end{array}$ & $68-006$ & Patapsco & $\begin{array}{l}1415 \\
\mathbf{E 9 2 5}\end{array}$ & & .376 & .266 & .212 & .198 & .237 \\
\hline Broadwater Waste Ireatment Plant & $71-020$ & Aquia & $\begin{array}{l}\text { N357 } \\
\text { E936 }\end{array}$ & & .013 & .019 & .026 & .057 & .000 \\
\hline Cedarhurst Water Company & $55-003$ & Patapsco & $\begin{array}{l}\text { N468 } \\
\text { E888 }\end{array}$ & & .000 & .003 & .003 & .003 & .003 \\
\hline $\begin{array}{l}\text { Central Avenue School, Anne Arundel } \\
\text { County Department of Utilities }\end{array}$ & $71-026$ & Magothy & $\begin{array}{l}\text { N398 } \\
\text { E924 }\end{array}$ & & .029 & .027 & .016 & .000 & .000 \\
\hline Chartwell Golf and Country Club & $61-009$ & Patapsco & $\begin{array}{l}\text { N458 } \\
\text { E814 }\end{array}$ & & .014 & .014 & .012 & .011 & .010 \\
\hline Chemetals, formerly Diamond Shamrock & $62-030$ & Patuxent & $\begin{array}{l}\text { N497 } \\
\mathbf{E} 923\end{array}$ & & .777 & .580 & .778 & .808 & .916 \\
\hline Chesapeake Mobile Court & $57-007$ & Patapsco & $\begin{array}{l}1479 \\
\text { E880 }\end{array}$ & & .036 & .036 & .022 & .035 & .033 \\
\hline Colony Seven Motor Inn & $60-024$ & Patuxent & $\begin{array}{l}\text { N467 } \\
\text { E864 }\end{array}$ & & .028 & .029 & .030 & .026 & .028 \\
\hline $\begin{array}{l}\text { Crain Bighway well, Anne Arundel } \\
\text { County Department of Utilities }\end{array}$ & 69-019 & Patapsco & $\begin{array}{l}\text { N475 } \\
\text { E904 }\end{array}$ & ' & .410 & .594 & .595 & .548 & .686 \\
\hline $\begin{array}{l}\text { Crofton, Anne Arundel County } \\
\text { Department of Ut111ties }\end{array}$ & $54-018$ & Patuxent & $\begin{array}{l}\mathbf{R 4 3 0} \\
\mathbf{E 8 9 2}\end{array}$ & & 1.344 & 1.142 & 1.152 & 1.076 & .933 \\
\hline Cromsv11le State Eospltal & $54-001$ & Magothy & $\begin{array}{l}\mathrm{K430} \\
\mathrm{E} 915\end{array}$ & & .184 & .265 & .187 & .202 & .199 \\
\hline $\begin{array}{l}\text { Dorsey wells, Anne Armind County } \\
\text { Depertment of Ut111ties }\end{array}$ & $68-018$ & Ratureat & $\begin{array}{l}\mathbf{X} 486 \\
\mathbf{2 9 0 0}\end{array}$ & & 1.771 & 1.541 & 2.608 & 2.055 & 2.017 \\
\hline $\begin{array}{l}\text { Dorsey wolls, Anne Arundel County } \\
\text { Department of Ut111ties }\end{array}$ & 69-018 & Patapsco & $\begin{array}{l}8486 \\
\mathbf{8 8 9 0}\end{array}$ & 1 & 3.058 & 4.367 & .622 & 2.530 & 2.055 \\
\hline $\begin{array}{l}\text { Elvaton wells, Anne Arundel County } \\
\text { Depertment of Ut1lities }\end{array}$ & $89-018$ & Patapsco & $\begin{array}{l}\mathbf{X 4 7 4} \\
\mathbf{5 9 0 7}\end{array}$ & , & .760 & .672 & .812 & .541 & .533 \\
\hline Epping Forest Water Works & $66-026$ & Magothy & $\begin{array}{l}1831 \\
2934\end{array}$ & i & .032 & .036 & .038 & .000 & .039 \\
\hline $\begin{array}{l}\text { Freestate Manegement Company. } \\
\text { Lake Village }\end{array}$ & $73-025$ & Patapsco & $\begin{array}{l}1 \% 74 \\
\mathbf{2 8 8 2}\end{array}$ & & .139 & .072 & .038 & .041 & .025 \\
\hline Fort George Meade, U.S. Army & $69-021$ & Patuxent & $\begin{array}{l}11459 \\
\mathbf{E 8 7 0}\end{array}$ & & .363 & .624 & .051 & .428 & .222 \\
\hline $\begin{array}{l}\text { Gibson Island, Ame Arundel County } \\
\text { Department of Ut111tiea }\end{array}$ & $71-034$ & Patapsco & $\begin{array}{l}1455 \\
\mathbf{8} 963\end{array}$ & & .099 & .075 & .054 & .078 & .081 \\
\hline $\begin{array}{l}\text { Glendale, Anne Arundel County } \\
\text { Dopartinent of Ut1lities }\end{array}$ & $69-019$ & Patapsco & $\begin{array}{l}\text { X483 } \\
\mathbf{2 9 1 0}\end{array}$ & & .462 & .561 & .000 & .529 & .383 \\
\hline $\begin{array}{l}\text { Barundale, Anne Arundel County } \\
\text { Departwent of Ut1lities }\end{array}$ & $89-019$ & Patapsco & $\begin{array}{l}1478 \\
E 910\end{array}$ & & 1.786 & 1.226 & .713 & .859 & 1.183 \\
\hline $\begin{array}{l}\text { Bereld Earbor, Anne Arundel County } \\
\text { Departwent of Ut1lities }\end{array}$ & $54-018$ & Patapsco & $\begin{array}{l}\mathbf{1} 430 \\
\mathbf{8 8 9 1}\end{array}$ & & .073 & .075 & .021 & .011 & .027 \\
\hline
\end{tabular}




\begin{tabular}{|c|c|c|c|c|c|c|c|c|c|c|c|}
\hline 1975 & 1974 & 1973 & 1972 & 1971 & 1970 & $1960-69$ & $1950-59$ & $1940-49$ & $1930-39$ & $1920-29$ & $1900-19$ \\
\hline 3.063 & 2.795 & 2.775 & 3.348 & 3.014 & 2.822 & 2.582 & 2.684 & 2.046 & 0.000 & $\begin{array}{c}0.000 \\
\text { First pumpage: }\end{array}$ & $\begin{array}{c}0.000 \\
?\end{array}$ \\
\hline .551 & .783 & .968 & .853 & .877 & 1.048 & 1.156 & .000 & .000 & .000 & First $\stackrel{.000}{\text { pumpage: }}$ & 1966 \\
\hline .006 & .009 & .008 & .009 & .008 & .006 & .003 & .000 & .000 & .000 & First $\stackrel{.000}{\text { pumpage: }}$ & 1979 \\
\hline .010 & .010 & .000 & .000 & .000 & .000 & .000 & .000 & .000 & .000 & First $\stackrel{.000}{\text { pumpage: }}$ & 1974 \\
\hline .004 & .003 & .003 & .001 & .001 & .001 & .001 & .003 & .002 & .000 & First $\stackrel{.000}{\text { pumpage: }}$ & 1977 \\
\hline .000 & .000 & .000 & .000 & .000 & .000 & .000 & .000 & .000 & .000 & First $\stackrel{.000}{\text { pumpage: }}$ & 1977 \\
\hline .194 & .158 & .137 & .158 & .112 & .102 & .123 & .000 & .000 & .000 & First $\stackrel{.000}{\text { pumpage: }}$ & 1968 \\
\hline .000 & .000 & .000 & .000 & .000 & .000 & .000 & .000 & .000 & .000 & First $\stackrel{.000}{\text { pumpage: }}$ & 1977 \\
\hline .003 & .003 & .003 & .003 & .003 & .022 & .020 & .008 & .000 & .000 & First $\stackrel{.000}{\text { pumpage: }}$ & $? .000$ \\
\hline .000 & .000 & .000 & .000 & .000 & .000 & .000 & .000 & .000 & .000 & First $\stackrel{.000}{\text { pumpage: }}$ & 1978 \\
\hline .008 & .005 & .004 & .004 & .004 & .004 & .003 & .000 & .000 & .000 & First $\stackrel{.000}{\text { pumpage: }}$ & 1961 \\
\hline .725 & .744 & .685 & .520 & .483 & .398 & .305 & .000 & .000 & .000 & First $\stackrel{.000}{\text { pumpage: }}$ & 19000 \\
\hline .030 & .029 & .027 & .026 & .025 & .025 & .021 & .010 & .000 & .000 & First $\stackrel{.000}{\text { pumpage: }}$ & 1958 \\
\hline .026 & .024 & .028 & .031 & .027 & .030 & .030 & .000 & .000 & .000 & First pumpage: & $\begin{array}{l}.000 \\
?\end{array}$ \\
\hline .356 & .175 & .086 & .046 & .010 & .030 & .001 & .000 & .000 & .000 & First $\stackrel{.000}{\text { pumpage: }}$ & 1969 \\
\hline .826 & 1.135 & .521 & .458 & .373 & .360 & .114 & .000 & .000 & .000 & First $\stackrel{.000}{\text { pumpage: }}$ & 1960 \\
\hline .211 & .235 & .244 & .573 & .527 & .520 & .390 & .358 & .356 & .329 & First $\stackrel{.000}{\text { pumpage: }}$ & $\begin{array}{l}.000 \\
?\end{array}$ \\
\hline 2.105 & 1.657 & 1.626 & 1.670 & 1.138 & .981 & .889 & .356 & .000 & .000 & First $\stackrel{.000}{\text { pumpage: }}$ & 1957 \\
\hline 1.115 & 1.402 & 1.491 & 1.510 & 1.456 & 1.485 & 1.156 & .512 & .000 & .000 & First $\stackrel{.000}{\text { pumpage: }}$ & $=000$ \\
\hline .442 & .368 & .525 & .449 & .496 & .138 & .000 & .000 & .000 & .000 & First $\stackrel{.000}{\text { pumpage: }}$ & 1970 \\
\hline .036 & .034 & .037 & .036 & .031 & .027 & .011 & .005 & .000 & .000 & First $\stackrel{.000}{\text { pumpage: }}$ & 1959 \\
\hline .019 & .016 & .014 & .000 & .000 & .000 & .000 & .000 & .000 & .000 & First $\stackrel{.000}{\text { pumpage: }}$ & 19000 \\
\hline .333 & .385 & .055 & .455 & .104 & .039 & .000 & .000 & .000 & .000 & First $\stackrel{.000}{\text { pumpage: }}$ & 19000 \\
\hline .069 & .077 & .077 & .072 & .064 & .078 & .085 & .067 & .068 & .027 & First $\stackrel{.014}{\text { pumpage: }}$ & 1928 \\
\hline .344 & .360 & .398 & .569 & .630 & .411 & .087 & .000 & .000 & .000 & First $\stackrel{.000}{\text { pumpage: }}$ & 1969 \\
\hline 1.227 & 1.258 & 1.311 & 1.295 & 1.354 & 1.476 & 1.414 & .795 & .000 & .000 & First $\stackrel{.000}{\text { pumpage: }}$ & $\frac{.000}{?}$ \\
\hline .032 & .310 & .260 & .229 & .187 & .123 & .093 & .000 & .000 & .000 & First $\stackrel{.000}{\text { pumpage: }}$ & 1967 \\
\hline
\end{tabular}


Ground-water withdrawals by large users in Ame Arundel County. 1900 through 1980--Continued

\begin{tabular}{|c|c|c|c|c|c|c|c|c|}
\hline App & $\begin{array}{c}\text { ppropriation } \\
\text { number }\end{array}$ & Aquifer & $\begin{array}{l}\text { Maryland grid } \\
\text { coordinates }\end{array}$ & 1980 & 1979 & 1978 & 1977 & 1976 \\
\hline Boliday Inn Laurel & $69-009$ & Patuxent & $\begin{array}{l}\text { N462 } \\
\text { E853 }\end{array}$ & 0.000 & 0.005 & 0.008 & 0.010 & 0.010 \\
\hline Holiday Mobile Estates & $63-008$ & Patuxent & $\begin{array}{l}\text { N477 } \\
\text { E871 }\end{array}$ & .046 & .044 & .044 & .043 & .047 \\
\hline Eomestead Gardens & None & Aquia & $\begin{array}{l}\text { N397 } \\
\text { E906 }\end{array}$ & .010 & .010 & .010 & .002 & .002 \\
\hline Boward Johnson's Restaurant and Inn & $55-004$ & Aquia & $\begin{array}{l}\text { N434 } \\
\text { E950 }\end{array}$ & .041 & .041 & .041 & .041 & .041 \\
\hline Koppers Company & $67-005$ & Patapsco & $\begin{array}{l}\text { N481 } \\
\text { E884 }\end{array}$ & .000 & .000 & .000 & .000 & .000 \\
\hline Koppers Company & $67-005$ & Patuxent & $\begin{array}{l}\text { N481 } \\
\text { E884 }\end{array}$ & .000 & .001 & .003 & .003 & .004 \\
\hline $\begin{array}{l}\text { Lake Shore Complex, including } \\
\text { Lake Shore Elementary School }\end{array}$ & $77-045$ & Magothy & $\begin{array}{l}\text { N464 } \\
\text { E943 }\end{array}$ & .036 & .028 & .025 & .022 & .000 \\
\hline Laurel Race Course & $47-003$ & Patuxent & $\begin{array}{l}\text { N463 } \\
\mathbf{E} 853\end{array}$ & .071 & .087 & .087 & .087 & .849 \\
\hline Lyons Creek Mobile Homes & $66-055$ & Aquia & $\begin{array}{l}\text { N349 } \\
\text { E890 }\end{array}$ & .037 & .017 & .040 & .029 & .013 \\
\hline Lyons Creek Mobile Bomes & $66-055$ & Magothy & $\begin{array}{l}\text { N347 } \\
\text { E892 }\end{array}$ & .037 & .009 & .032 & .021 & .015 \\
\hline MacMillan Bloedel Packaging, Limited & $62-003$ & Patapsco & $\begin{array}{l}\text { N470 } \\
\text { E887 }\end{array}$ & .012 & .014 & .014 & .015 & .014 \\
\hline $\begin{array}{l}\text { Maryland City-Fort Meade West, Anne } \\
\text { Arundel County Department of Utilities }\end{array}$ & $65-033$ & Patuxent & $\begin{array}{l}\text { N461 } \\
\text { E851 }\end{array}$ & .563 & .538 & .512 & .535 & .540 \\
\hline Maryland Manor Bomes & $65-032$ & Magothy & $\begin{array}{l}\text { N374 } \\
\text { E892 }\end{array}$ & .070 & .045 & .051 & .051 & .052 \\
\hline $\begin{array}{l}\text { Meade Village, Anne Arundel County } \\
\text { Department of Utillties }\end{array}$ & $69-019$ & Patapsco & $\begin{array}{l}\text { N474 } \\
\text { E882 }\end{array}$ & .112 & .117 & .107 & .085 & .098 \\
\hline Nevamar Corporation & $70-012$ & Patapsco & $\begin{array}{l}\text { N458 } \\
\text { E886 }\end{array}$ & 1.665 & 2.665 & 2.410 & 2.632 & 2.797 \\
\hline Nevamar Corporation & $70-012$ & Patuxent & $\begin{array}{l}\text { N457 } \\
\text { E886 }\end{array}$ & .699 & .139 & .162 & .200 & .026 \\
\hline $\begin{array}{l}\text { Parkway Industrial wells, Anne Arundel } \\
\text { County Department of Utilities }\end{array}$ & 69-019 & Patuxent & $\begin{array}{l}\text { N489 } \\
\text { E886 }\end{array}$ & .000 & .000 & .000 & .000 & .000 \\
\hline Parkway Manor/Econo Lodge & $54-019$ & Patuxent & $\begin{array}{l}\text { N476 } \\
\text { E870 }\end{array}$ & .010 & .008 & .008 & .008 & .005 \\
\hline Pasadena Water Company & $62-028$ & Patapsco & $\begin{array}{l}\text { N465 } \\
\text { E921 }\end{array}$ & .000 & .000 & .000 & .047 & .047 \\
\hline $\begin{array}{l}\text { Phillips Drive well, Anne Arundel } \\
\text { County Department of Utilities }\end{array}$ & $69-019$ & Patapsco & $\begin{array}{l}\text { N480 } \\
\text { E907 }\end{array}$ & .656 & .425 & .467 & .364 & .369 \\
\hline Pine Bills Corporation & $74-002$ & Patapsco & $\begin{array}{l}\text { N467 } \\
\mathrm{E} 892\end{array}$ & .001 & .015 & .015 & .015 & .015 \\
\hline $\begin{array}{l}\text { Pines on Severn, Anne Arundel County } \\
\text { Department of Utilities }\end{array}$ & $53-008$ & Magothy & $\begin{array}{l}\text { N433 } \\
\text { E939 }\end{array}$ & $n 00$ & .000 & .000 & .010 & .090 \\
\hline Provinces Water Company & $70-046$ & Patuxent & $\begin{array}{l}\text { N474 } \\
\text { E876 }\end{array}$ & .286 & .243 & .233 & .230 & .189 \\
\hline $\begin{array}{l}\text { Quarterfield well, Anne Arundel County } \\
\text { Department of Utilities }\end{array}$ & $69-019$ & Patapsco & $\begin{array}{l}\text { N475 } \\
\text { E900 }\end{array}$ & .732 & .338 & .262 & .003 & .022 \\
\hline Revell Square Water Corporation & $76-001$ & Patapsco & $\begin{array}{l}\text { N436 } \\
\text { E960 }\end{array}$ & .021 & .007 & .001 & .000 & .000 \\
\hline Riva Development & $75-023$ & Magothy & $\begin{array}{l}\text { N407 } \\
\text { E919 }\end{array}$ & .027 & .025 & .011 & .000 & .000 \\
\hline Robin Bood Dell Trailer Park & $69-006$ & Patuxent & $\begin{array}{l}\text { N486 } \\
\text { E881 }\end{array}$ & .011 & .011 & .010 & .010 & .010 \\
\hline
\end{tabular}




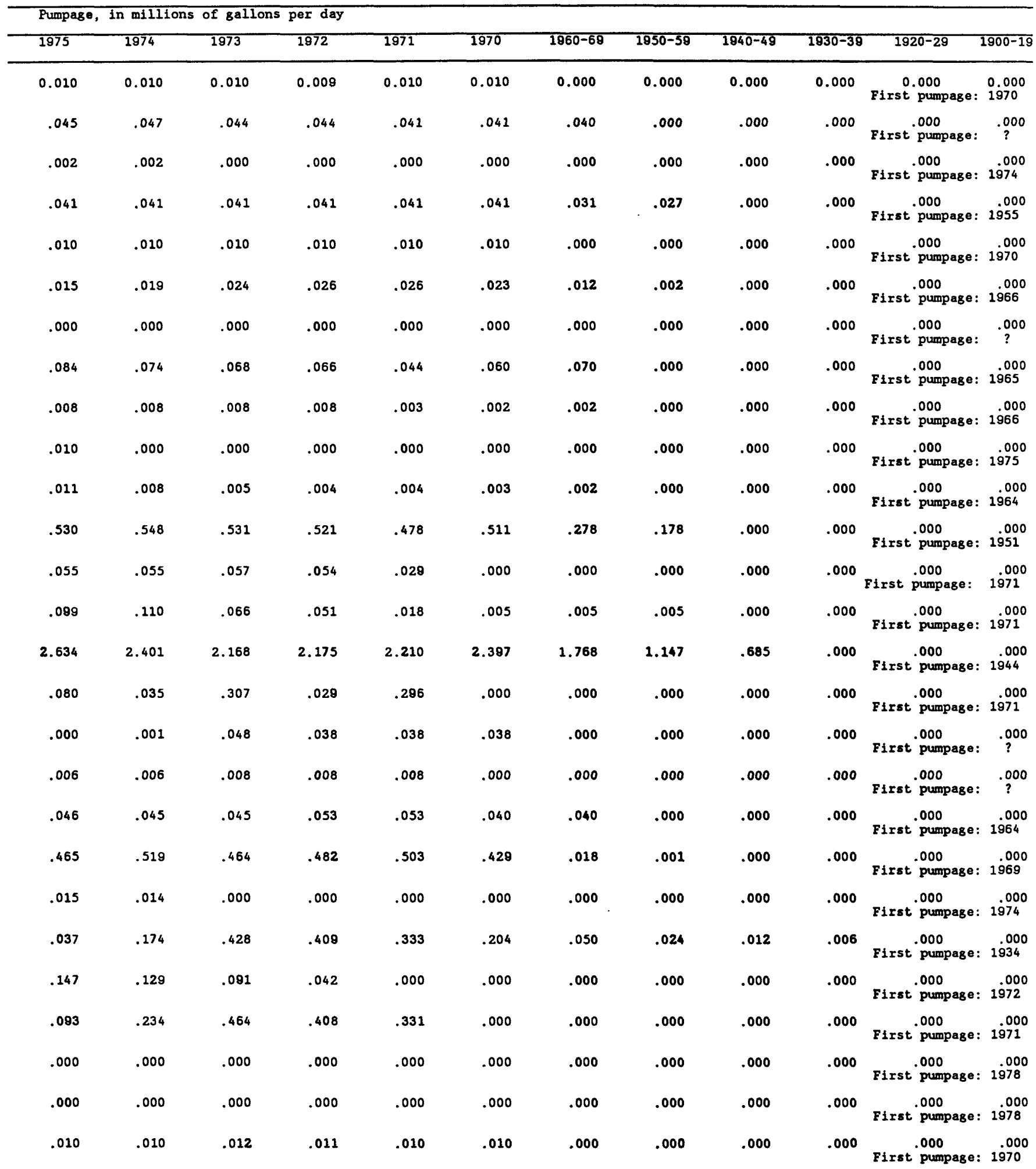




\begin{tabular}{|c|c|c|c|c|c|c|c|c|}
\hline User & $\begin{array}{l}\text { Appropriation } \\
\text { number }\end{array}$ & Aquifer & $\begin{array}{l}\text { Maryland grid } \\
\text { coordinates }\end{array}$ & 1980 & 1979 & 1978 & 1977 & 1976 \\
\hline Rol-Park Trailer Park & $58-005$ & Patapsco & $\begin{array}{l}\mathrm{K} 488 \\
\mathrm{E} 904\end{array}$ & 0.017 & 0.015 & 0.013 & 0.012 & 0.010 \\
\hline Sandy Point State Park & 49-004 & Magothy & $\begin{array}{l}\text { N434 } \\
\text { E969 }\end{array}$ & .011 & .010 & .010 & .010 & .010 \\
\hline $\begin{array}{l}\text { Sands Road Joint Venture, } \\
\text { Patuxent Mobile Estates }\end{array}$ & $73-013$ & Aqui a & $\begin{array}{l}\mathbf{N} 393 \\
\mathbf{E 8 9 0}\end{array}$ & .047 & .000 & .000 & .000 & .000 \\
\hline $\begin{array}{l}\text { Sawnill Creek wells, Anne Arundel } \\
\text { County Department of Utilities }\end{array}$ & 69-019 & Patapsco & $\begin{array}{l}\text { K487 } \\
\text { E905 }\end{array}$ & 1.844 & 1.679 & .818 & 1.124 & 1.350 \\
\hline Severn Mobile Home Court & $55-016$ & Patapsco & $\begin{array}{l}\text { N458 } \\
\text { E882 }\end{array}$ & .015 & .015 & .016 & .015 & .015 \\
\hline $\begin{array}{l}\text { Severna Park, Anne Arundel County } \\
\text { Department of Utilities }\end{array}$ & $53-008$ & Patapsco & $\begin{array}{l}\text { N450 } \\
\text { E929 }\end{array}$ & 4.181 & 3.167 & 2.724 & 2.011 & 2.355 \\
\hline Severn Water Company & $69-016$ & Patapsco & $\begin{array}{l}\text { N465 } \\
\mathbf{E} 880\end{array}$ & .405 & .388 & .380 & .332 & .304 \\
\hline Shermood Forest Water Service & $63-029$ & Magothy & $\begin{array}{l}\text { N433 } \\
\text { E928 }\end{array}$ & .059 & .057 & .058 & .066 & .055 \\
\hline Southern Senior High School & $68-011$ & Magothy & $\begin{array}{l}\text { K378 } \\
\mathbf{E} 908\end{array}$ & .033 & .032 & .020 & .014 & .000 \\
\hline Southdown Shores Water Works & $58-008$ & Aquia & $\begin{array}{l}\mathrm{N} 403 \\
\mathrm{E} 921\end{array}$ & .030 & .041 & .022 & .022 & .022 \\
\hline Summer BA11, Incorporated & $60-021$ & Magothy & $\begin{array}{l}\$ 428 \\
\mathbf{E 9 1 8}\end{array}$ & .012 & .012 & .015 & .013 & .013 \\
\hline Sylvan Shores & $56-002$ & Magothy & $\begin{array}{l}\text { N408 } \\
\text { E919 }\end{array}$ & .040 & .042 & .041 & .044 & .038 \\
\hline Sylvan Shorea & $56-002$ & Quaternary & $\begin{array}{l}\$ 408 \\
\mathbf{E} 919\end{array}$ & .000 & .000 & .000 & .000 & .000 \\
\hline $\begin{array}{l}\text { Thelma Avenue, Anne Arundel County } \\
\text { Department of Utilities }\end{array}$ & $69-019$ & Patapsco & $\begin{array}{l}\text { N481 } \\
\mathbf{E g 0 3}\end{array}$ & .207 & .283 & .339 & .314 & .341 \\
\hline Tracy's Landins School & $61-027$ & Aqui a & $\begin{array}{l}\text { N346 } \\
\text { E916 }\end{array}$ & .003 & .003 & .003 & .003 & .003 \\
\hline Transit Truck Stop & $62-026$ & Patapsco & $\begin{array}{l}\text { N462 } \\
\text { E905 }\end{array}$ & .019 & .019 & .019 & .020 & .016 \\
\hline Two Guys Department Store & $57-004$ & Patapsco & $\begin{array}{l}\text { N487 } \\
\text { E908 }\end{array}$ & .000 & .000 & .000 & .000 & .200 \\
\hline USS Agricultural Chemical Company & $67-042$ & Patuxent & $\begin{array}{l}\text { N499 } \\
\text { E918 }\end{array}$ & .000 & .007 & .009 & .007 & .011 \\
\hline $\begin{array}{l}\text { U.S. Air Force, Davidsonville } \\
\text { housing }\end{array}$ & $32-004$ & Magothy & $\begin{array}{l}1 \% 13 \\
\mathbf{E} 890\end{array}$ & .000 & .000 & .012 & .000 & .000 \\
\hline U.S. Naval Academy & $32-003$ & Patapsco & $\begin{array}{l}\text { N419 } \\
\text { E946 }\end{array}$ & 1.605 & 1.413 & 1.461 & 1.400 & 1.259 \\
\hline U.S. Naval Academy Golf Course & $70-041$ & Patapsco & $\begin{array}{l}\text { N423 } \\
\mathbf{E} 953\end{array}$ & .000 & .000 & .000 & .011 & .011 \\
\hline $\begin{array}{l}\text { U.S. Naval Ship Research and } \\
\text { Development Center }\end{array}$ & $32-001$ & Patapsco & $\begin{array}{l}\text { X421 } \\
\text { E949 }\end{array}$ & .311 & .331 & .341 & .329 & .390 \\
\hline $\begin{array}{l}\text { U.S. Naval Ship Resaarch and } \\
\text { Development Center }\end{array}$ & $32-001$ & Magothy & $\begin{array}{l}\text { N421 } \\
\text { E949 }\end{array}$ & .140 & .143 & .161 & .137 & .168 \\
\hline Wayson's Mobile Court & $60-008$ & Aquia & $\begin{array}{l}\text { N356 } \\
\text { E884 }\end{array}$ & .047 & .047 & .055 & .055 & .053 \\
\hline Westinghouse Elactric Corporation & $66-027$ & Patapsco & $\begin{array}{l}K 429 \\
E 968\end{array}$ & .022 & .023 & .022 & .019 & .029 \\
\hline Whispering Woods & $75-014$ & Patapsco & $\begin{array}{l}\text { N436 } \\
\text { E949 }\end{array}$ & .036 & .035 & .060 & .046 & .050 \\
\hline Woodfield Fish and Oyster Company & $54-003$ & Aquia & $\begin{array}{l}\text { N370 } \\
\text { E930 }\end{array}$ & .044 & .040 & .035 & .032 & .043 \\
\hline
\end{tabular}




\begin{tabular}{|c|c|c|c|c|c|c|c|c|c|c|}
\hline 1975 & 1974 & 1973 & 1972 & 1971 & 1970 & $1960-69$ & $1950-59$ & $1940-49$ & $1930-39$ & $1920-29$ \\
\hline 0.010 & 0.010 & 0.010 & 0.010 & 0.010 & 0.010 & 0.008 & 0.003 & 0.000 & 0.000 & $\begin{array}{cl}0.000 & 0.000 \\
\text { First pumpage: } & 1959\end{array}$ \\
\hline .010 & .010 & .010 & .010 & .010 & .010 & .007 & .004 & .000 & .000 & First $\stackrel{.000}{\text { pumpage: }} \quad .000$ \\
\hline .000 & .000 & .000 & .000 & .000 & .000 & .000 & .000 & .000 & .000 & First pumpage: $\stackrel{.000}{?}$ \\
\hline .851 & 1.010 & 1.390 & 1.480 & 1.510 & 1.410 & 1.232 & .519 & .192 & .089 & First pumpage: 1926 \\
\hline .013 & .016 & .024 & .019 & .018 & .016 & .012 & .004 & .000 & .000 & First pumpage: 1956 \\
\hline 2.136 & 1.997 & 1.557 & 1.291 & 1.189 & .758 & .551 & .142 & .042 & .000 & First $\stackrel{.000}{\text { pumpage: }}: .000$ \\
\hline .255 & .225 & .174 & .132 & .035 & .000 & .000 & .000 & .000 & .000 & First $\stackrel{.000}{\text { pumpage: }}: .000$ \\
\hline .048 & .051 & .055 & .053 & .047 & .070 & .060 & .000 & .000 & .000 & First $\stackrel{.000}{\text { pumpaga: }} 1.000$ \\
\hline .000 & .000 & .000 & .000 & .000 & .000 & .000 & .000 & .000 & .000 & First $\stackrel{.000}{\text { pumpage }}: 1977$ \\
\hline .022 & .022 & .020 & .024 & .016 & .016 & .011 & .002 & .000 & .000 & First $\stackrel{.000}{\text { pumpage: }} 1957$ \\
\hline .010 & .010 & .010 & .010 & .009 & .007 & .003 & .000 & .000 & .000 & First $\stackrel{.000}{\text { pumpage: }} \quad .000$ \\
\hline .034 & .043 & .047 & .052 & .043 & .041 & .036 & .035 & .000 & .000 & First $\stackrel{.000}{\text { pumpage: }} 1.000$ \\
\hline .000 & .000 & .000 & .000 & .000 & .000 & .000 & .033 & .027 & .014 & First $\stackrel{.000}{\text { pumpage: }}: 1934$ \\
\hline .303 & .256 & .273 & .293 & .045 & .000 & .000 & .000 & .000 & .000 & First $\stackrel{.000}{\text { pumpaga: }} \quad .000$ \\
\hline .003 & .003 & .003 & .003 & .033 & .003 & .003 & .000 & .000 & .000 & Flrst $\stackrel{.000}{\text { pumpage: }} \quad 1962$ \\
\hline .027 & .029 & .027 & .020 & .020 & .020 & .020 & .000 & .000 & .000 & Flrst $\stackrel{.000}{\text { pumpage: }} \quad .000$ \\
\hline .200 & .200 & .178 & .282 & .178 & .200 & .200 & .000 & .000 & .000 & Flest $\stackrel{.000}{\text { pumpage: }} \quad \stackrel{.000}{?}$ \\
\hline .008 & .008 & .011 & .041 & .041 & .041 & .037 & .034 & .019 & .000 & F1rst $\stackrel{.000}{\text { pumpage: }} 1940$ \\
\hline .000 & .000 & .000 & .000 & .000 & .000 & .000 & .000 & .000 & .000 & 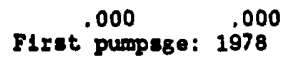 \\
\hline 1.386 & 1.370 & 1.257 & 1.350 & 1.315 & 1.275 & .085 & 1.028 & 1.000 & 1.000 & $\begin{array}{c}1.000 \\
\text { Flrst pumpage: } 1925\end{array}$ \\
\hline .012 & .021 & .021 & .011 & .021 & .011 & .002 & .002 & .001 & .000 & F1rst $\stackrel{.000}{\text { pumpage: }} \quad .000$ \\
\hline .329 & .298 & .365 & .280 & .314 & .315 & .383 & .384 & .307 & .000 & Flrst $\stackrel{.000}{\text { pumpage: }}: \frac{.000}{1948}$ \\
\hline .164 & .200 & .200 & .200 & .200 & .180 & .190 & .188 & .150 & .000 & First $\frac{.000}{\text { pumpage: }} \quad .000$ \\
\hline .057 & .051 & .049 & .049 & .047 & .041 & .036 & .000 & .000 & .000 & First $\begin{array}{l}.000 \\
\text { pumpage: } \\
1966\end{array}$ \\
\hline .035 & .028 & .033 & .043 & .090 & .061 & .027 & .000 & .000 & .000 & First $\begin{array}{ll}.000 & .000 \\
\text { pumpage: } & 1967\end{array}$ \\
\hline .050 & .000 & .000 & .000 & .000 & .000 & .000 & .000 & .000 & .000 & First $\begin{array}{l}.000 \\
\text { pumpage : }\end{array} 1975$ \\
\hline .055 & .048 & .048 & .055 & .055 & .041 & .039 & .028 & .025 & .023 & First pumpage: 1920 \\
\hline
\end{tabular}


Ground-water withdrawals by large users in the Coastal Plain area of Baltilore City. 1900 through 1980

(Sources: Maryland Water Resources Administration files, Maryland Geological Survey reports, county water and sewerage plans, and miscellaneous county reports)

\begin{tabular}{|c|c|c|c|c|c|c|c|c|}
\hline User & $\begin{array}{l}\text { Appropriation } \\
\text { number }\end{array}$ & Aquifer & $\begin{array}{l}\text { Maryland grid } \\
\text { coordinates }\end{array}$ & 1980 & 1979 & 1978 & 1977 & $\overline{1976}$ \\
\hline Canton District & None & Patuxent & $\begin{array}{l}\text { N521 } \\
\text { E924 }\end{array}$ & 0.000 & 0.000 & 0.000 & 0.000 & 0.000 \\
\hline Crown Cork \& Seal & None & Patuxent & $\begin{array}{l}\text { N532 } \\
\text { E923 }\end{array}$ & .000 & .000 & .000 & .000 & .000 \\
\hline Curtis Bay District & None & Patapsco & $\begin{array}{l}\text { N509 } \\
\text { E917 }\end{array}$ & .000 & .000 & .000 & .000 & .000 \\
\hline Curtis Bay District & None & Patuxent & $\begin{array}{l}\text { N509 } \\
\text { E917 }\end{array}$ & .000 & .000 & .000 & .000 & .000 \\
\hline Dundalk District & None & Patuxent & $\begin{array}{l}\text { N517 } \\
\text { E937 }\end{array}$ & .000 & .000 & .000 & .000 & .000 \\
\hline $\begin{array}{l}\text { F.M.C. Corporation, Industrial } \\
\text { Chemical Division }\end{array}$ & $60-002$ & Patuxent & $\begin{array}{l}\text { N510 } \\
\text { E919 }\end{array}$ & .421 & .593 & .374 & .533 & .723 \\
\hline Falrfield District & None & Patuxent & $\begin{array}{l}\text { N512 } \\
\text { E923 }\end{array}$ & .000 & .000 & .000 & .000 & .000 \\
\hline Federal Yeast Corporation & $60-001$ & Patuxent & $\begin{array}{l}\text { N522 } \\
\text { E932 }\end{array}$ & 2.585 & 2.705 & 2.590 & 2.262 & 2.052 \\
\hline Harbor District & None & Patuxent & $\begin{array}{l}\text { N521 } \\
\text { E924 }\end{array}$ & .000 & .000 & .000 & .000 & .000 \\
\hline Harbor District & None & Quaternary & $\begin{array}{l}\text { NS21 } \\
\text { E924 }\end{array}$ & .000 & .000 & .000 & .000 & .000 \\
\hline Highlandtown District & None & Patuxent & $\begin{array}{l}\text { N532 } \\
\text { E923 }\end{array}$ & .000 & .000 & .000 & .000 & .000 \\
\hline Hood Vinegar Company & $56-001$ & Patuxent & $\begin{array}{l}\text { N535 } \\
\text { E924 }\end{array}$ & .079 & .065 & .047 & .029 & .043 \\
\hline Monarch Rubber Company & None & Patuxent & $\begin{array}{l}\text { N532 } \\
\text { E923 }\end{array}$ & .000 & .000 & .000 & .000 & .000 \\
\hline Paul Jones Company & None & Patuxent & $\begin{array}{l}\text { N532 } \\
\text { E923 }\end{array}$ & .000 & .000 & .000 & .000 & .000 \\
\hline Pennys Ivania Water and Power & None & Patuxent & $\begin{array}{ll}\mathbf{N 5 3 2} \\
\mathbf{E} 923\end{array}$ & .000 & .000 & .000 & .000 & .000 \\
\hline Schluderberg-Kurdle Incorporated & $58-001$ & Patuxent & $\begin{array}{l}\text { N532 } \\
\text { E923 }\end{array}$ & .234 & .261 & .213 & .186 & .137 \\
\hline
\end{tabular}

Ground-water withdrawals by large users in the Coastal Plain area of Baltimare County, 1900 through 1980

(Sources: Maryland Water Resources Administration files, Maryland Geological Survey reports, county water and sewerage plans, and miscellaneous county reports)

\begin{tabular}{|c|c|c|c|c|c|c|c|c|}
\hline User & $\begin{array}{c}\text { Appropriation } \\
\text { number }\end{array}$ & Aquifer & $\begin{array}{l}\text { Maryland } 8 \mathrm{rid} \\
\text { ooordinates }\end{array}$ & 1980 & 1979 & 1978 & 1977 & 1976 \\
\hline Amercian Yeast Corporation & $69-020$ & Paturent & $\begin{array}{l}\text { N524 } \\
\text { E953 }\end{array}$ & 0.700 & 0.700 & 0.700 & 0.700 & 0.700 \\
\hline Bethlehem Steel Corporation & $46-003$ & Patapsco & $\begin{array}{l}\text { N504 } \\
\text { E944 }\end{array}$ & .000 & .000 & .000 & .000 & .000 \\
\hline Bethlehem Steel Corporation & $46-003$ & Patuxent & $\begin{array}{l}\text { N507 } \\
\text { E945 }\end{array}$ & 3.606 & 4.929 & 5.422 & 5.151 & 5.553 \\
\hline Eastern Stainless Steel Corporation & $56-006$ & Patuxent & $\begin{array}{l}\text { N535 } \\
\text { E940 }\end{array}$ & .964 & .822 & .806 & .877 & .947 \\
\hline $\begin{array}{l}\text { Joseph E. Seagram \& Sons (Calvert } \\
\text { Distiliery) }\end{array}$ & $78-017$ & Quaternary & $\begin{array}{l}\text { N504 } \\
\text { E886 }\end{array}$ & .419 & .545 & .438 & .358 & .445 \\
\hline Joseph S. Merritt Incorporated & $59-009$ & Patapsco & $\begin{array}{l}\text { N519 } \\
\text { E941 }\end{array}$ & .017 & .018 & .017 & .013 & .021 \\
\hline Rocky Point Golf Course & $70-006$ & Patuxent & $\begin{array}{l}\text { N518 } \\
\text { E966 }\end{array}$ & .038 & .015 & .035 & .056 & .025 \\
\hline
\end{tabular}




\begin{tabular}{|c|c|c|c|c|c|c|c|c|c|c|c|}
\hline $\begin{array}{l}\text { Pumpas } \\
1975\end{array}$ & $\begin{array}{l}197111 \\
1974\end{array}$ & $\begin{array}{l}\text { of } 8 \text { all } \\
1973\end{array}$ & $\begin{array}{c}\text { per day } \\
1972\end{array}$ & 1971 & 1970 & $1960-69$ & $1950-59$ & $1940-49$ & $1930-39$ & $1920-29$ & $1900-19$ \\
\hline 0.000 & 0.000 & 0.000 & 0.000 & 0.000 & 0.000 & 0.077 & 0.212 & 1.148 & 2.187 & $\begin{array}{l}2.255 \\
\text { First pumpage: }\end{array}$ & $\begin{array}{l}2.489 \\
1918\end{array}$ \\
\hline .000 & .000 & .000 & .000 & .000 & .000 & .000 & 2.691 & 1.427 & 1.096 & First $\stackrel{.000}{\text { pumpage }}$ & 1939 \\
\hline .000 & .000 & .000 & .000 & .000 & .000 & .000 & .186 & .621 & .821 & First pumpage: & .000 \\
\hline .000 & .000 & .000 & .000 & .000 & .000 & .000 & .588 & 2.442 & 2.797 & $\begin{array}{l}2.351 \\
\text { First pumpage: }\end{array}$ & $\begin{array}{l}1.405 \\
1915\end{array}$ \\
\hline .000 & .000 & .000 & .000 & .000 & .000 & .455 & 2.886 & 5.211 & 4.397 & $\begin{array}{l}3.654 \\
\text { First pumpage: }\end{array}$ & $\begin{array}{l}2.222 \\
1900\end{array}$ \\
\hline .865 & 1.484 & 1.811 & 2.074 & 2.003 & 2.002 & 1.929 & 1.730 & 1.619 & .000 & First $\frac{.000}{\text { pumpage : }}$ & $\stackrel{.000}{?}$ \\
\hline .000 & .000 & .000 & .000 & .000 & .000 & 1.781 & 2.561 & 4.725 & 4.068 & $\begin{array}{l}3.388 \\
\text { First pumpage: }\end{array}$ & $\begin{array}{l}1.756 \\
1900\end{array}$ \\
\hline 1.725 & 1.632 & 1.617 & 1.739 & 1.496 & 1.375 & 1.052 & .840 & 1.000 & .000 & First pumpage: & $\stackrel{.000}{?}$ \\
\hline .000 & .000 & .000 & .000 & .000 & .000 & .000 & .881 & 2.091 & 1.964 & $\begin{array}{l}1.701 \\
\text { First pumpage: }\end{array}$ & $\begin{array}{l}2.226 \\
1918\end{array}$ \\
\hline .000 & .000 & .000 & .000 & .000 & .000 & .000 & .047 & .192 & .274 & First $\stackrel{.274}{\text { pumpage : }}$ & $: .274$ \\
\hline .000 & .000 & .000 & .000 & .000 & .000 & .000 & .000 & .000 & 1.676 & $\begin{array}{l}1.129 \\
\text { First pumpage: }\end{array}$ & $?_{?}^{.518}$ \\
\hline .087 & .065 & .050 & .087 & .078 & .068 & .065 & .000 & .000 & .000 & First pumpage: & $: .000$ \\
\hline .000 & .000 & .000 & .000 & .000 & .000 & .000 & .053 & .052 & .016 & First pumpage: & $: .000$ \\
\hline .000 & .000 & .000 & .000 & .000 & .000 & .000 & .098 & .117 & .110 & First pumpage: & 1939 \\
\hline .000 & .000 & .000 & .000 & .000 & .000 & .000 & .007 & .009 & .005 & $\begin{array}{l}.000 \\
\text { First pumpage: }\end{array}$ & 1.000 \\
\hline .219 & .305 & .174 & .210 & .151 & .164 & .256 & .714 & .870 & .685 & First pumpage: & $\stackrel{.000}{?}$ \\
\hline
\end{tabular}

\begin{tabular}{|c|c|c|c|c|c|c|c|c|c|c|c|}
\hline 1975 & 1974 & 1973 & 1972 & 1971 & 1970 & $1960-69$ & $1950-59$ & $1940-49$ & $1930-39$ & $1920-29$ & $1900-19$ \\
\hline 0.700 & 0.700 & 0.700 & 0.700 & 0.700 & 0.700 & 0.700 & 0.000 & 0.000 & 0.000 & $\begin{array}{l}0.000 \\
\text { First pumpage: }\end{array}$ & $\begin{array}{l}0.000 \\
1969\end{array}$ \\
\hline .000 & .000 & .000 & .000 & .632 & 1.240 & 4.327 & 4.089 & 6.019 & 4.474 & $\begin{array}{l}2.099 \\
\text { First pumpage: }\end{array}$ & $\begin{array}{l}1.203 \\
1915\end{array}$ \\
\hline 4.975 & 5.414 & 5.578 & 5.025 & 6.589 & 7.778 & 5.608 & 5.695 & 6.905 & 4.474 & $\begin{array}{l}2.099 \\
\text { First pumpage: }\end{array}$ & $: \begin{array}{l}1.203 \\
1915\end{array}$ \\
\hline 1.033 & 1.020 & 1.041 & 1.068 & 1.096 & 1.096 & 1.068 & 1.144 & 1.855 & 1.123 & First $\stackrel{.333}{\text { pumpage: }}$ & $: 1923$ \\
\hline .378 & .565 & .508 & .633 & .617 & .529 & .488 & .480 & .459 & .000 & $\begin{array}{l}.000 \\
\text { First pumpage: }\end{array}$ & $: \begin{array}{l}.000 \\
1942\end{array}$ \\
\hline .015 & .014 & .016 & .015 & .019 & .015 & .013 & .010 & .005 & .003 & First pumpage: & $: \dot{90}_{13}^{003}$ \\
\hline .025 & .026 & .022 & .029 & .028 & .015 & .000 & .000 & .000 & .000 & First $\begin{array}{l}.000 \\
\text { pumpage }:\end{array}$ & $: 1970$ \\
\hline
\end{tabular}


Ground-water withdrawals by large users in Calvert Couty, 1900 throush 1900

(Sources: Maryland Water Resources Administration 211es, Marylend Geolopleal Survey reports, county water and sewerage plans, and miscellaneous county reports)

\begin{tabular}{|c|c|c|c|c|c|c|c|c|}
\hline User & $\begin{array}{l}\text { Appropriation } \\
\text { number }\end{array}$ & Aquiter & $\begin{array}{l}\text { faryland grild } \\
\text { coordinates }\end{array}$ & 1880 & I679 & 1978 & 2977 & 1976 \\
\hline A.I. Cassell Ut1lity Corporation & $59-002$ & Aquil a & $\begin{array}{l}n 268 \\
\text { E935 }\end{array}$ & 0.038 & 0.028 & 0.028 & 0.028 & 0.027 \\
\hline $\begin{array}{l}\text { Baltimore Gas and Electric } \\
\text { Company, Calvert Cliffs }\end{array}$ & $69-010$ & Aquisa & $\begin{array}{l}\mathbf{n 2 1 0} \\
\mathbf{E} 950\end{array}$ & .121 & .254 & .252 & .236 & .205 \\
\hline Cavalier Country & 70-004 & Magethy & $\begin{array}{l}17333 \\
\mathbf{E 9 0 5}\end{array}$ & .048 & .042 & .038 & .053 & .049 \\
\hline Calvert Memorial Bospital & $52-001$ & Aquile & $\begin{array}{l}2284 \\
\text { Eo15 }\end{array}$ & .039 & .032 & .012 & .012 & .012 \\
\hline Calvert Middle School & $73-008$ & Aquila & $\begin{array}{l}\operatorname{mes0} \\
\mathbf{E} 917\end{array}$ & .004 & .005 & .008 & .007 & .010 \\
\hline $\begin{array}{l}\text { Calvert Sonior High School and } \\
\text { Vocational Toch Center }\end{array}$ & $70-005$ & Aqusle & $\begin{array}{l}1283 \\
\mathbf{E} 210\end{array}$ & .000 & .008 & .012 & .014 & .011 \\
\hline Chesapeake Beach water system & 72-003 & Aquila & $\begin{array}{l}\text { n320 } \\
\text { E031 }\end{array}$ & .047 & .038 & $.038 i$ & .038 & .029 \\
\hline Chesapeake Ranch Water Company & $60-002$ & Pines Rolne & $\begin{array}{l}\text { H293 } \\
\text { Ees4 }\end{array}$ & .028 & .027 & .023 & .014 & .023 \\
\hline Chesapeake Ranch Water Company & $60-002$ & Aquila & $\begin{array}{l}\text { n193 } \\
\text { E975 }\end{array}$ & .088 & .092 & .077 & .046 & .077 \\
\hline Columbia LNG Corporation & $73-014$ & Aquia & $\begin{array}{l}1203 \\
8060\end{array}$ & .022 & .012 & .008 & .006 & .027 \\
\hline Dares Beach Water Company & $74-002$ & Pines Rotas & $\begin{array}{l}2284 \\
2037\end{array}$ & .020 & .022 & .004 & .000 & .000 \\
\hline $\begin{array}{l}\text { Kenwood Beach; Calvert water } \\
\text { system }\end{array}$ & $68-009$ & Pines Rosnt & $\begin{array}{l}\text { N261 } \\
\mathbf{Z 9 4 2}\end{array}$ & .017 & .021 & .018 & .017 & .016 \\
\hline $\begin{array}{l}\text { Long Beach; Calvert water } \\
\text { aystem }\end{array}$ & $82-001$ & Pines Posas & $\begin{array}{l}\mathbf{n} 227 \\
\mathbf{2 0 5 2}\end{array}$ & .082 & .061 & .054 & .038 & .038 \\
\hline $\begin{array}{l}\text { Long Beach; Calvert water } \\
\text { system }\end{array}$ & $62-001$ & Aqula & $\begin{array}{l}1227 \\
\mathbf{2 0 5 2}\end{array}$ & .015 & .015 & .013 & .027 & .027 \\
\hline Northern Middle School & 72-001 & Nagothy & $\begin{array}{l}1310 \\
\mathbf{E} 898\end{array}$ & .017 & .018 & .015 & .015 & .012 \\
\hline Northern High School & $72-041$ & Magothy & $\begin{array}{l}1310 \\
\mathbf{E} 890\end{array}$ & .028 & .018 & .015 & .015 & .011 \\
\hline Prince Frederick water system & $74-005$ & squla & $\begin{array}{l}\text { m259 } \\
\text { EOI6 }\end{array}$ & .102 & .086 & .094 & .096 & .093 \\
\hline Scientist Clifes Service Company & $53-002$ & Aguia & $\begin{array}{l}\mathbf{2 0 6} \\
\mathbf{2 0 3 0}\end{array}$ & .012 & .023 & .010 & .019 & .016 \\
\hline Scientist Cliffs Service Company & $53-002$ & Blnes Polnt & $\begin{array}{l}\mathbf{2} 248 \\
\mathbf{E} 937\end{array}$ & .028 & .023 & .030 & .030 & .030 \\
\hline Shores of Calvert & $72-002$ & Magothy & $\begin{array}{l}\mathbf{1 3 3 0} \\
\mathbf{5 8 9 2}\end{array}$ & .037 & .032 & .028 & .025 & .030 \\
\hline U.S. Navy, Randlo Cliff: & $32-002$ & Aquia & $\begin{array}{l}1901 \\
\mathbf{2 0 3 3}\end{array}$ & .038 & .038 & .030 & .042 & .058 \\
\hline U.S. Navy, Solomon Test Facility & $32-001$ & Aquia & $\begin{array}{l}1184 \\
\operatorname{coss}\end{array}$ & .000 & .082 & .071 & .088 & .062 \\
\hline White Sands Corporation & 58-002 & Rlues Rolne & $\begin{array}{l}2225 \\
2047\end{array}$ & .008 & .003 & .002 & .013 & .013 \\
\hline
\end{tabular}




\begin{tabular}{|c|c|c|c|c|c|c|c|c|c|c|c|}
\hline 1975 & 1974 & 1973 & 1972 & 1971 & 1970 & $1960-69$ & $1950-59$ & $1940-49$ & $1930-39$ & $1920-29$ & $1900-1$ \\
\hline 0.027 & 0.027 & 0.026 & 0.026 & 0.026 & 0.012 & 0.011 & 0.003 & 0.000 & 0.000 & $\begin{array}{c}0.000 \\
\text { First pumpage: }\end{array}$ & $: \begin{array}{l}0.000 \\
1951\end{array}$ \\
\hline .213 & .124 & .145 & .137 & .137 & .000 & .000 & .000 & .000 & .000 & First .000 & $: 1971$ \\
\hline .047 & .047 & .044 & .041 & .038 & .000 & .000 & .000 & .000 & .000 & First $\stackrel{.000}{\text { pumpage }}$ & $: 1971$ \\
\hline .011 & .011 & .011 & .010 & .005 & .005 & .005 & .004 & .000 & .000 & First pumpage: & $: 1953$ \\
\hline .011 & .008 & .006 & .004 & .005 & .006 & .006 & .000 & .000 & .000 & First $\stackrel{.000}{\text { purmpage: }}$ & $: 1962$ \\
\hline .008 & .008 & .010 & .011 & .010 & .005 & .000 & .000 & .000 & .000 & First $\stackrel{.000}{\text { purppage }}$ & $: 1970$ \\
\hline .023 & .031 & .030 & .030 & .030 & .030 & .028 & .010 & .005 & .005 & First purppage: & $: 1900$ \\
\hline .018 & .016 & .014 & .012 & .012 & .024 & .022 & .000 & .000 & .000 & First .000 & $: .000$ \\
\hline .058 & .055 & .046 & .040 & .040 & .028 & .027 & .000 & .000 & .000 & First .000 & $: 1961$ \\
\hline .000 & .000 & .000 & .000 & .000 & .000 & .000 & .000 & .000 & .000 & First $\stackrel{.000}{\text { pumpage: }}$ & $: 1976$ \\
\hline .000 & .000 & .000 & .000 & .000 & .000 & .000 & .000 & .000 & .000 & First .000 & $: 1978$ \\
\hline .016 & .016 & .017 & .005 & .005 & .005 & .004 & .000 & .000 & .000 & First .000 & $: .000$ \\
\hline .038 & .031 & .033 & .030 & .030 & .030 & .026 & .000 & .000 & .000 & First $\stackrel{.000}{\text { pumpage }}$ & $: \stackrel{.000}{?}$ \\
\hline .027 & .027 & .021 & .019 & .019 & .019 & .022 & .027 & .000 & .000 & First purmpage: & $: \quad .000$ \\
\hline .005 & .004 & .003 & .000 & .000 & .000 & .000 & .000 & .000 & .000 & First .000 & $: 1973$ \\
\hline .006 & .004 & .003 & .000 & .000 & .000 & .000 & .000 & .000 & .000 & First pumpage: & $: 1972$ \\
\hline .093 & .090 & .090 & .090 & .090 & .090 & .000 & .000 & .000 & .000 & First .000 & $: 1970$ \\
\hline .008 & .011 & .011 & .008 & .009 & .008 & .008 & .000 & .000 & .000 & First pumpage: & $: 1965$ \\
\hline .033 & .027 & .024 & .021 & .019 & .021 & .024 & .020 & .008 & .000 & First pumpage: & $: 1947$ \\
\hline .030 & .004 & .004 & .004 & .004 & .004 & .000 & .000 & .000 & .000 & First pumpage: & $: 1975$ \\
\hline .079 & .044 & .068 & .068 & .082 & .096 & .093 & .063 & .060 & .000 & First pumpage: & 19000 \\
\hline .075 & .075 & .075 & .075 & .075 & .075 & .100 & .519 & .751 & .000 & $\begin{array}{l}.000 \\
\text { First pumpage: }\end{array}$ & 19000 \\
\hline .014 & .012 & .012 & .012 & .012 & .012 & .012 & .002 & .000 & .000 & First $\stackrel{.000}{\text { pumpage: }}$ & 1950 \\
\hline
\end{tabular}


Ground-water withdrewals by large wsers in Cacoline Counts, 1900 through 1980

(Sources: Maryland Water Resources Administration files, Maryland Geologfcal Survey reports, county water and sewerage plans, and miscellaneous county reports)

\begin{tabular}{|c|c|c|c|c|c|c|c|c|}
\hline User & $\begin{array}{c}\text { Appropriation } \\
\text { number }\end{array}$ & Aquifer & $\begin{array}{l}\text { yland grid } \\
\text { ordinates }\end{array}$ & 1980 & 1979 & 1978 & 1977 & 1976 \\
\hline Cooklyn Dairies & $49-002$ & Choptank & $\begin{array}{l}\text { N438 } \\
\mathbf{E} 1145\end{array}$ & 0.000 & 0.000 & 0.000 & 0.000 & 0.000 \\
\hline David M. King Canning Company & $63-001$ & Quaternary & $\begin{array}{l}\text { K438 } \\
\text { E1144 }\end{array}$ & .000 & .000 & .000 & .000 & .000 \\
\hline Denton, Town of & $71-002$ & Piney Point & $\begin{array}{l}\text { N383 } \\
\text { E1133 }\end{array}$ & .355 & .268 & .291 & .273 & .266 \\
\hline Electro-therm, Incorporated & $70-002$ & Piney Point & $\begin{array}{l}\text { N386 } \\
\text { E1128 }\end{array}$ & .008 & .008 & .014 & .017 & .015 \\
\hline Federa1sburg, Town of & 75-006 & Columbia & $\begin{array}{l}\text { N315 } \\
\text { E1153 }\end{array}$ & .498 & .378 & .384 & .389 & .448 \\
\hline Federalsburg, Town of & $75-006$ & Federelsburg & $\begin{array}{l}\text { N315 } \\
\text { E1153 }\end{array}$ & .166 & .126 & 128 & .130 & .149 \\
\hline Grasonville Fisheries, Incorporated & $70-007$ & Frederica & $\begin{array}{l}\text { N406 } \\
\text { E1116 }\end{array}$ & .130 & .110 & .175 & .095 & .110 \\
\hline Greensboro, Town of & $70-009$ & Piney Point & $\begin{array}{l}\text { N418 } \\
\text { E1138 }\end{array}$ & .171 & .188 & .182 & .185 & .200 \\
\hline John N. Wright Jr., Incorporated & $50-003$ & Calvert & $\begin{array}{l}\text { N313 } \\
\text { E1148 }\end{array}$ & .000 & .000 & .000 & .000 & .000 \\
\hline John N. Wright, Jr., Incorporated & $46-001$ & Federalsburg & $\begin{array}{l}\text { N319 } \\
\text { E1125 }\end{array}$ & .056 & .056 & .056 & .059 & .058 \\
\hline Maryland Plestics & $50-002$ & Calvert & $\begin{array}{l}\text { N315 } \\
\text { E1153 }\end{array}$ & .001 & .001 & .002 & .001 & .002 \\
\hline $\begin{array}{l}\text { Northern Caroline Bigh School and } \\
\text { Denton Elementary School }\end{array}$ & $78-004$ & Piney Point & $\begin{array}{l}\text { N337 } \\
\text { E1135 }\end{array}$ & .017 & .017 & .017 & .017 & .017 \\
\hline $\begin{array}{l}\text { Northern Caroline High School and } \\
\text { Denton Elementary School }\end{array}$ & $78-004$ & Cheswold & $\begin{array}{l}\text { N337 } \\
\text { E1135 }\end{array}$ & .021 & .021 & .021 & .022 & .022 \\
\hline Nuttle Canning Company & $68-006$ & Federalsburs & $\begin{array}{l}\text { N368 } \\
\text { E1163 }\end{array}$ & .000 & .000 & .040 & .040 & .040 \\
\hline Preston, Town of & $79-006$ & Pleistocene & $\begin{array}{l}\text { N322 } \\
\text { E1111 }\end{array}$ & .070 & .070 & .070 & .070 & .070 \\
\hline Ridgely, Town of & $79-005$ & Frederica & $\begin{array}{l}\text { N407 } \\
\text { E1116 }\end{array}$ & .186 & .186 & .184 & .181 & .178 \\
\hline Saulsbury Brothers, Incorporated & 46-002 & Quaternary & $\begin{array}{l}\text { N405 } \\
\text { E1115 }\end{array}$ & .237 & .256 & .272 & .274 & .236 \\
\hline T. Noble Jarrell Canning Company & $65-001$ & Quaternary & $\begin{array}{l}\text { N438 } \\
\text { E1145 }\end{array}$ & .000 & .000 & .144 & .144 & .144 \\
\hline The Benedictine School & 49-003 & Frederica & $\begin{array}{l}\text { N428 } \\
\text { E1117 }\end{array}$ & .024 & .024 & .022 & .025 & .022 \\
\hline Wheatley Canning Company & $46-004$ & Celvert & $\begin{array}{l}\text { N315 } \\
\text { E1153 }\end{array}$ & .000 & .000 & .000 & .000 & .000 \\
\hline Wilson Laurel Farms, Incorporated & $51-002$ & Choptank & $\begin{array}{l}\text { N384 } \\
\text { E1128 }\end{array}$ & .000 & .000 & .000 & .000 & .000 \\
\hline
\end{tabular}




\begin{tabular}{|c|c|c|c|c|c|c|c|c|c|c|c|}
\hline 1975 & 1974 & 1973 & 1972 & 1971 & 1970 & $1960-69$ & $1950-59$ & $1940-49$ & $1930-39$ & $1920-29$ & $\overline{1900-19}$ \\
\hline 0.000 & 0.000 & 0.000 & 0.090 & 0.090 & 0.090 & 0.090 & 0.090 & 0.090 & 0.090 & $\begin{array}{c}0.000 \\
\text { First pumpage: }\end{array}$ & $\begin{array}{l}0.000 \\
1932\end{array}$ \\
\hline .000 & .000 & .000 & .000 & .000 & .041 & .041 & .000 & .000 & .000 & First $\stackrel{.000}{\text { pumpage: }}$ & 1963 \\
\hline .321 & .291 & .274 & .274 & .268 & .262 & .241 & .200 & .163 & .143 & First $\stackrel{.090}{\text { pumpage: }}$ & .036 \\
\hline .015 & .015 & .015 & .015 & .000 & .000 & .000 & .000 & .000 & .000 & First $\stackrel{.000}{\text { pumpage: }}$ & 1972 \\
\hline .000 & .000 & .000 & .000 & .000 & .000 & .000 & .000 & .000 & .000 & First pumpage: & $\begin{array}{l}.000 \\
?\end{array}$ \\
\hline .548 & .548 & .521 & .521 & .521 & .521 & .503 & .484 & .416 & .144 & First pumpage: & $\begin{array}{l}.030 \\
?\end{array}$ \\
\hline .110 & .110 & .126 & .101 & .075 & .113 & .018 & .000 & .000 & .000 & First pumpage: & 1969 \\
\hline .172 & .164 & .164 & .164 & .164 & .151 & .118 & .079 & .063 & .047 & First $\stackrel{.021}{\text { pumpage: }}$ & 1916 \\
\hline .000 & .000 & .000 & .000 & .000 & .000 & .027 & .027 & .000 & .000 & First $\stackrel{.000}{\text { pumpage: }}$ & $\frac{.000}{?}$ \\
\hline .058 & .074 & .074 & .074 & .074 & .084 & .108 & .110 & .000 & .000 & First $\stackrel{.000}{\text { pumpage: }}$ & $\frac{.000}{?}$ \\
\hline .002 & .002 & .001 & .002 & .001 & .090 & .090 & .090 & .000 & .000 & First $\stackrel{.000}{\text { pumpage: }}$ & 1950 \\
\hline .017 & .011 & .011 & .011 & .011 & .011 & .011 & .011 & .000 & .000 & First $\stackrel{.000}{\text { pumpage: }}$ & 1.000 \\
\hline .022 & .022 & .022 & .015 & .015 & .015 & .014 & .000 & .000 & .000 & First $\stackrel{.000}{\text { pumpage: }}$ & 1963 \\
\hline .040 & .040 & .040 & .040 & .040 & .040 & .040 & .040 & .040 & .040 & First $\stackrel{.000}{\text { pumpage: }}$ & 19000 \\
\hline .070 & .070 & .070 & .070 & .070 & .070 & .070 & .070 & .070 & .070 & First pumpage: & 19026 \\
\hline .178 & .170 & .164 & .159 & .151 & .142 & .112 & .066 & .031 & .024 & First pumpage: & 1.020 \\
\hline .219 & .170 & .218 & .219 & .219 & .219 & .500 & .500 & .500 & .500 & F1rst $\stackrel{.500}{\text { pumpage: }}$ & 19000 \\
\hline .144 & .144 & .144 & .000 & .144 & .144 & .144 & .144 & .144 & .144 & First $\stackrel{.144}{\text { pumpage: }}$ & 19000 \\
\hline .017 & .006 & .005 & .005 & .005 & .005 & .005 & .005 & .004 & .030 & First $\stackrel{.003}{\text { pumpage: }}$ & 1920 \\
\hline .000 & .000 & .000 & .150 & .150 & .150 & .150 & .150 & .150 & .000 & First $\stackrel{.000}{\text { pumpage: }}$ & 1946 \\
\hline .000 & .000 & .000 & .000 & .215 & .115 & .133 & .118 & .000 & .000 & First pumpage: & $?_{?}^{.000}$ \\
\hline
\end{tabular}


Ground-water withdrawals by large users in the Coestal Plain area of Cecil Cocmty, 1900 through 1980

(Sources: Maryland Water Resources Administration files, Maryland Geolosical Survey reports, county water and sewerage plans, and miscellaneous county reports)

\begin{tabular}{|c|c|c|c|c|c|c|c|c|c|}
\hline User & $\begin{array}{l}\text { Appropriation } \\
\text { number }\end{array}$ & Aquifer & Mar & $\begin{array}{l}\text { yland grid } \\
\text { ordinates }\end{array}$ & 1980 & 1979 & 1978 & 1977 & 1976 \\
\hline Buttonwood Beach & $74-017$ & Potomac & Group & $\begin{array}{l}\text { N592 } \\
\text { E1091 }\end{array}$ & 0.029 & 0.009 & 0.014 & 0.027 & 0.014 \\
\hline Carpenters Point water system & $67-023$ & Potomac & Group & $\begin{array}{l}\mathbf{N 6 2 7} \\
\mathrm{E} 1079\end{array}$ & .010 & .012 & .015 & .014 & .014 \\
\hline Cecilton, Town of & $72-004$ & Magothy & & $\begin{array}{l}\text { H574 } \\
\mathbf{E} 1120\end{array}$ & .025 & .026 & .030 & .025 & .022 \\
\hline Chesapeake City & $78-018$ & Potomac & Group & $\begin{array}{l}\text { N619 } \\
\mathrm{E} 1134\end{array}$ & .168 & .164 & .162 & .159 & .159 \\
\hline Crystal Beach & $69-014$ & Potomac & Group & $\begin{array}{l}\text { N589 } \\
\text { E1090 }\end{array}$ & .018 & .017 & .000 & .000 & .000 \\
\hline EIk Heck State Park & $60-013$ & Potomac & Group & $\begin{array}{l}\mathrm{N} 606 \\
\mathrm{E} 1086\end{array}$ & .025 & .024 & .025 & .027 & .000 \\
\hline $\begin{array}{l}\text { Elkton, Town of: Holly Hall } \\
\text { water system }\end{array}$ & $61-007$ & Potomac & Group & $\begin{array}{l}\text { N645 } \\
\text { E1135 }\end{array}$ & .213 & .239 & .238 & .196 & .164 \\
\hline $\begin{array}{l}\text { Holly Hall Terrace Utility } \\
\text { Corporation }\end{array}$ & $54-007$ & Potomac & Group & $\begin{array}{l}\text { N646 } \\
\text { E1134 }\end{array}$ & .000 & .000 & .000 & .000 & .000 \\
\hline Hooker Plastics & $71-002$ & Pleistoc & cene & $\begin{array}{l}\text { N633 } \\
\mathrm{E} 1078\end{array}$ & .000 & .000 & .000 & .000 & .000 \\
\hline Meadowien Utilities Incorporated & $58-005$ & Potomac & Group & $\begin{array}{l}\text { N664 } \\
\text { E1139 }\end{array}$ & .113 & .110 & .114 & .000 & .000 \\
\hline Morning Cheer, Sandy Cove & $62-001$ & Potomac & Group & $\begin{array}{l}\text { K624 } \\
\text { E1091 }\end{array}$ & .006 & .012 & .015 & .011 & .010 \\
\hline Pinea Aills Subdivision & $61-002$ & Potomac & Group & $\begin{array}{l}\text { M629 } \\
\text { E1114 }\end{array}$ & .021 & .012 & .012 & .013 & .013 \\
\hline Pirelli Cable Corporation & $60-011$ & Potomac & Group & $\begin{array}{l}\text { H650 } \\
\text { E1127 }\end{array}$ & .038 & .041 & .043 & .043 & .042 \\
\hline Thiokol Chemical Company & $57-003$ & Potcmac & Group & $\begin{array}{l}\text { N649 } \\
\text { E1119 }\end{array}$ & .024 & .025 & .023 & .026 & .021 \\
\hline $\begin{array}{l}\text { Town and Country Mobile Park, } \\
\text { Incorporated }\end{array}$ & $66-025$ & Potomac & Group & $\begin{array}{l}\text { K650 } \\
\text { E1103 }\end{array}$ & .030 & .016 & .004 & .004 & .004 \\
\hline
\end{tabular}




\begin{tabular}{|c|c|c|c|c|c|c|c|c|c|c|c|}
\hline 1975 & 1974 & 1973 & 1872 & 1971 & 1970 & $1960-69$ & $1950-59$ & $1940-49$ & $1930-39$ & $1920-29$ & $1900-19$ \\
\hline 0.007 & 0.000 & 0.000 & 0.000 & 0.000 & 0.000 & 0.000 & 0.000 & 0.000 & 0.000 & $\begin{array}{l}0.000 \\
\text { First pumpage: }\end{array}$ & $\begin{array}{l}0.000 \\
1975\end{array}$ \\
\hline .014 & .016 & .014 & .000 & .000 & .000 & .000 & .000 & .000 & .000 & First pumpage: & 1973 \\
\hline .022 & .020 & .024 & .028 & .027 & .027 & .027 & .000 & .000 & .000 & First pumpage: & : 1868 \\
\hline .156 & .153 & .253 & .252 & .248 & .248 & .139 & .124 & .091 & .055 & First pumpage: & 19000 \\
\hline .000 & .000 & .000 & .000 & .000 & .000 & .000 & .000 & .000 & .000 & First pumpage: & $\stackrel{.000}{?}$ \\
\hline .000 & .000 & .000 & .000 & .000 & .000 & .000 & .000 & .000 & .000 & First pumpage: & .000 \\
\hline .137 & .110 & .205 & .221 & .000 & .000 & .000 & .000 & .000 & .000 & Elrst pumpaga: & $: \stackrel{.000}{1972}$ \\
\hline .000 & .000 & .000 & .000 & .220 & .220 & .202 & .026 & .000 & .000 & First pumpage: & 1854 \\
\hline .000 & .000 & .004 & .008 & .022 & .000 & .000 & .000 & .000 & .000 & First pumpage: & 19071 \\
\hline .000 & .000 & .000 & .000 & .000 & .000 & .000 & .000 & .000 & .000 & First pumpage: & .000 \\
\hline .010 & .011 & .012 & .000 & .000 & .000 & .000 & .000 & .000 & .000 & First $\frac{.000}{\text { pumpage: }}$ & $: 1972$ \\
\hline .013 & .013 & .024 & .025 & .025 & .014 & .000 & .000 & .000 & .000 & First $\stackrel{.000}{\text { pumpage: }}$ & $\begin{array}{l}.000 \\
?\end{array}$ \\
\hline .043 & .042 & .043 & .053 & .038 & .036 & .038 & .000 & .000 & .000 & First $\stackrel{.000}{\text { pumpage }}$ & $: \frac{.000}{1961}$ \\
\hline .024 & .028 & .037 & .037 & .037 & .036 & .022 & .018 & .016 & .000 & First $\begin{array}{l}.000 \\
\text { pumpage }\end{array}$ & $: 1948$ \\
\hline .004 & .003 & .003 & .003 & .000 & .000 & .000 & .000 & .000 & .000 & First $\stackrel{.000}{\text { pumpage: }}$ & $: 1972$ \\
\hline
\end{tabular}


Ground-water withdrawals by large users in Charles County, 1900 throush 188

(Sources: Maryland Water Resources Administration files, Maryland Geological Survey reports, county water and sewerage plans, and miscellaneous county reports)

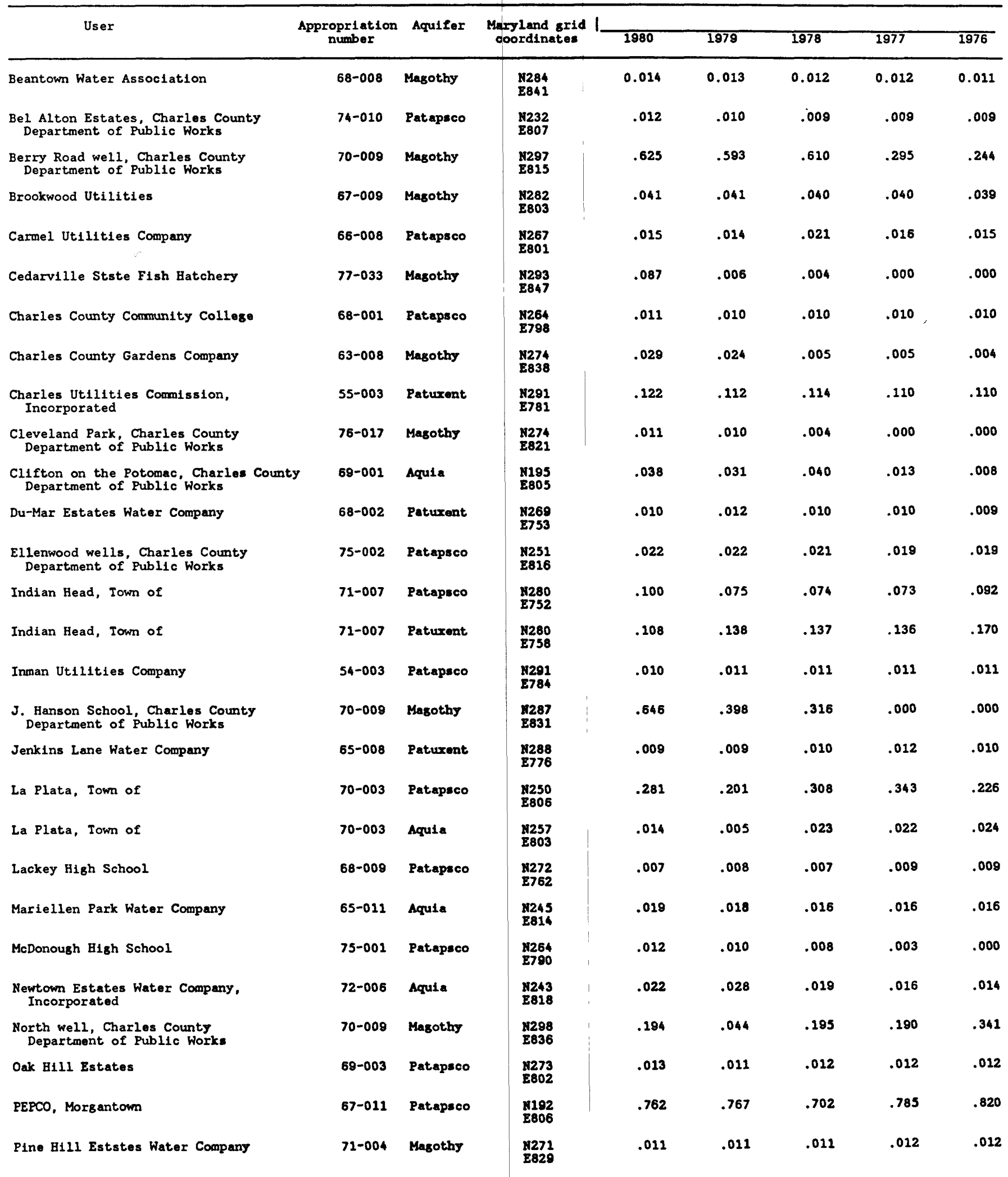




\begin{tabular}{|c|c|c|c|c|c|c|c|c|c|c|c|}
\hline 1975 & 1874 & 1973 & 1972 & 1971 & 1970 & $1960-69$ & $1950-59$ & $1940-49$ & $1930-39$ & $1920-29$ & $1900-19$ \\
\hline 0.011 & 0.012 & 0.010 & 0.008 & 0.008 & 0.008 & 0.008 & 0.000 & 0.000 & 0.000 & $\begin{array}{l}0.000 \\
\text { First pumpage: }\end{array}$ & $\begin{array}{l}0.000 \\
1869\end{array}$ \\
\hline .008 & .000 & .000 & .000 & .000 & .000 & .000 & .000 & .000 & .000 & First pumpage: & 1975 \\
\hline .000 & .000 & .000 & .000 & .000 & .000 & .000 & .000 & .000 & .000 & First pumpage: & 1976 \\
\hline .039 & .039 & .039 & .038 & .038 & .027 & .027 & .000 & .000 & .000 & First pumpage: & 1968 \\
\hline .014 & .012 & .010 & .008 & .008 & .008 & .008 & .000 & .000 & .000 & First pumpage: & 1966 \\
\hline .000 & .000 & .000 & .000 & .000 & .000 & .000 & .000 & .000 & .000 & First pumpage: & 1978 \\
\hline .009 & .009 & .009 & .009 & .008 & .008 & .004 & .000 & .000 & .000 & First pumpage: & 1968 \\
\hline .004 & .005 & .005 & .005 & .004 & .004 & .002 & .000 & .000 & .000 & First $\stackrel{.000}{\text { pumpage }}$ & 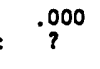 \\
\hline .110 & .110 & .110 & .110 & .110 & .110 & .077 & .015 & .000 & .000 & First pumpage: & 1956 \\
\hline .000 & .000 & .000 & .000 & .000 & .000 & .000 & .000 & .000 & .000 & First pumpage: & 19878 \\
\hline .005 & .003 & .001 & .000 & .000 & .000 & .000 & .000 & .000 & .000 & First pumpage: & $: 1973$ \\
\hline .006 & .007 & .007 & .007 & .003 & .002 & .000 & .000 & .000 & .000 & First pumpage: & 1970 \\
\hline .016 & .000 & .000 & .000 & .000 & .000 & .000 & .000 & .000 & .000 & First pumpage: & $: 1975$ \\
\hline .065 & .074 & .074 & .190 & .236 & .192 & .141 & .091 & .000 & .000 & First pumpage: & $: 1953$ \\
\hline .121 & .138 & .138 & .000 & .000 & .000 & .000 & .000 & .000 & .000 & First pumpage : & $: 1973$ \\
\hline .011 & .011 & .011 & .010 & .010 & .010 & .010 & .000 & .000 & .000 & First pumpage: & $=1962$ \\
\hline .000 & .000 & .000 & .000 & .000 & .000 & .000 & .000 & .000 & .000 & F1rst pumpage: & 1978 \\
\hline .010 & .010 & .010 & .010 & .010 & .010 & .008 & .007 & .000 & .000 & First pumpage: & $: 1956$ \\
\hline .212 & .150 & .151 & .140 & .148 & .170 & .253 & .118 & .089 & .000 & First pumpage: & 19000 \\
\hline .019 & .017 & .020 & .017 & .018 & .000 & .000 & .000 & .000 & .000 & First pumpage: & $: 1971$ \\
\hline .011 & .012 & .013 & .012 & .012 & .012 & .011 & .000 & .000 & .000 & First pumpage: & $: 1969$ \\
\hline .016 & .014 & .011 & .005 & .002 & .000 & .000 & .000 & .000 & .000 & First pumpage: & $: 1973$ \\
\hline .000 & .000 & .000 & .000 & .000 & .000 & .000 & .000 & .000 & .000 & First pumpage: & $: 1977$ \\
\hline .011 & .010 & .008 & .002 & .000 & .000 & .000 & .000 & .000 & .000 & First pumpage: & $: 1972$ \\
\hline .330 & .336 & .253 & .223 & .212 & .210 & .144 & .000 & .000 & .000 & First $\stackrel{.000}{\text { pumpage: }}$ & $: 1962$ \\
\hline .012 & .012 & .013 & .012 & .012 & .011 & .000 & .000 & .000 & .000 & First purpage: & $: 1970$ \\
\hline .818 & .842 & .784 & .859 & .670 & .274 & .000 & .000 & .000 & .000 & First puropage: & $: .000$ \\
\hline .012 & .012 & .013 & .001 & .000 & .000 & .000 & .000 & .000 & .000 & First purppage: & $: 1972$ \\
\hline
\end{tabular}


Ground-water withdravals by large users in Charlea Counts. 1900 throudh 1000-Cont1nued

\begin{tabular}{|c|c|c|c|c|c|c|c|c|}
\hline User & $\begin{array}{l}\text { Appropriation } \\
\text { number }\end{array}$ & Aquifer & $\begin{array}{l}\text { Maryland srid } 1 \\
\text { coordinates }\end{array}$ & 1980 & 1979 & 1978 & 1977 & 1976 \\
\hline $\begin{array}{l}\text { Potomac Heights Home Omers } \\
\text { Association }\end{array}$ & $55-008$ & Paturent & $\begin{array}{l}\mathbf{1 2 8 0} \\
\mathbf{E 7 6 1}\end{array}$ & 0.139 & 0.131 & 0.141 & 0.139 & 0.139 \\
\hline Potomac Utilities Corporation & $66-005$ & Patuxent & $\begin{array}{l}\mathbf{n 2 9 9} \\
\mathbf{E 7 7 9}\end{array}$ & .046 & .047 & .050 & .041 & .041 \\
\hline Potomac Utilities Corporation & $66-005$ & Patapsco & $\begin{array}{l}\mathbf{1 2 9 9} \\
\mathbf{E 7 7 9}\end{array}$ & .012 & .012 & .012 & .010 & .010 \\
\hline $\begin{array}{l}\text { Quiet Acres and Billingsley } \\
\text { Forest }\end{array}$ & 71-003 & Patuxent & $\begin{array}{l}\mathbf{H 2 8 1} \\
\mathbf{E 7 9 1}\end{array}$ & .012 & .010 & .012 & .012 & .014 \\
\hline $\begin{array}{l}\text { South well, Charles County } \\
\text { Department of Public Works }\end{array}$ & $70-009$ & Magothy & $\begin{array}{l}\mathbf{1 2 7 9} \\
\mathbf{E 8 1 7}\end{array}$ & .266 & .291 & .080 & .125 & .272 \\
\hline Stardust Motel & $58-003$ & Magothy & $\begin{array}{l}\mathbf{m} 203 \\
\mathbf{E B 2 8}\end{array}$ & .000 & .000 & .000 & .000 & .000 \\
\hline $\begin{array}{l}\text { St. Charles City, Charles County } \\
\text { Department of Public Works }\end{array}$ & $70-009$ & Magothy & $\begin{array}{l}\mathbf{W 2 8 5} \\
\mathbf{E B 2 5}\end{array}$ & .285 & .365 & .485 & .487 & .346 \\
\hline Trimac Water Company, Incorporated & $55-001$ & Patapsco & $\begin{array}{l}\mathbf{1 2 7 0} \\
\mathbf{E} 630\end{array}$ & .015 & .014 & .012 & .000 & .000 \\
\hline Turkey Hill Water Company & $70-001$ & Patapsco & $\begin{array}{l}\mathbf{n 2 7 1} \\
\mathbf{E 8 0 2}\end{array}$ & .010 & .010 & .010 & .010 & .010 \\
\hline $\begin{array}{l}\text { U.S. Naval Ordnance Station, } \\
\text { Indian Bead }\end{array}$ & $71-005$ & Ratapsco & $\begin{array}{l}\mathbf{n} 279 \\
\mathbf{E 7 4 8}\end{array}$ & 2.040 & 1.179 & 1.096 & 1.068 & 1.057 \\
\hline $\begin{array}{l}\text { U.S. Naval Ordnance Station, } \\
\text { Indian Head }\end{array}$ & $71-005$ & Patuxent & $\begin{array}{l}1272 \\
E 750\end{array}$ & .000 & .000 & .000 & .000 & .000 \\
\hline Woodland Village & $57-003$ & Patuxent & $\begin{array}{l}1277 \\
E 757\end{array}$ & .031 & .022 & .025 & .025 & .025 \\
\hline White Plains Park & $74-007$ & Patapsco & $\begin{array}{l}\mathbf{n 2 7 0} \\
\mathbf{E 8 2 2}\end{array}$ & .073 & .016 & .100 & .055 & .041 \\
\hline White Plains Water Company & 85-007 & Magothy & $\begin{array}{l}\text { n274 } \\
\text { E810 }\end{array}$ & .022 & .021 & .020 & .018 & .017 \\
\hline
\end{tabular}




\begin{tabular}{|c|c|c|c|c|c|c|c|c|c|c|c|}
\hline 1975 & 1974 & 1973 & 1972 & 1971 & 1970 & $1960-68$ & $1850-59$ & $1940-49$ & $1930-39$ & $1920-29$ & $1900-19$ \\
\hline 0.128 & 0.141 & 0.133 & 0.128 & 0.123 & 0.123 & 0.120 & 0.120 & 0.100 & 0.094 & $\begin{array}{c}0.000 \\
\text { First pumpage: }\end{array}$ & $\begin{array}{l}0.000 \\
1941\end{array}$ \\
\hline .039 & .048 & .039 & .025 & .000 & .000 & .000 & .000 & .000 & .000 & First $\stackrel{.000}{\text { pumpage: }}$ & 19000 \\
\hline .008 & .012 & .010 & .006 & .032 & .032 & .030 & .000 & .000 & .000 & First $\stackrel{.000}{\text { pumpage: }}$ & 1966 \\
\hline .014 & .014 & .014 & .014 & .000 & .000 & .000 & .000 & .000 & .000 & First $\stackrel{.000}{\text { pumpage: }}$ & 1972 \\
\hline .347 & .326 & .246 & .223 & .212 & .210 & .136 & .000 & .000 & .000 & First $\stackrel{.000}{\text { pumpage: }}$ & 1962 \\
\hline .000 & .001 & .001 & .001 & .002 & .002 & .009 & .000 & .000 & .000 & First $\stackrel{.000}{\text { pumpage: }}$ & 1960 \\
\hline .330 & .289 & .368 & .360 & .378 & .370 & .000 & .000 & .000 & .000 & First $\stackrel{.000}{\text { prampage: }}$ & 19000 \\
\hline .000 & .000 & .000 & .000 & .000 & .000 & .000 & .000 & .000 & .000 & First $\stackrel{.000}{\text { pumpage: }}$ & $\frac{.000}{?}$ \\
\hline .010 & .005 & .003 & .001 & .001 & .000 & .000 & .000 & .000 & .000 & First pumpage: & 1971 \\
\hline 1.301 & 1.617 & 1.438 & 1.438 & 1.440 & 1.524 & 1.149 & .855 & .522 & .616 & F1rst $\stackrel{.787}{\text { pumpage: }}$ & $\frac{.425}{?}$ \\
\hline .000 & .000 & .000 & .612 & .710 & .653 & .492 & .366 & .224 & .000 & First pumpage: & $=1945$ \\
\hline .025 & .025 & .031 & .031 & .031 & .022 & .017 & .015 & .000 & .000 & First $\stackrel{.000}{\text { pumpage: }}$ & 1957 \\
\hline .027 & .027 & .027 & .022 & .019 & .016 & .014 & .000 & .000 & .000 & First $\stackrel{.000}{\text { pumpage: }}$ & $=1960$ \\
\hline .015 & .015 & .013 & .011 & .010 & .008 & .006 & .000 & .000 & .000 & First pumpage: & 1965 \\
\hline
\end{tabular}


Ground-water withdrawals by 1arge users in Dorchester Coumty, 1900| through 1980

(Sources: Maryland Water Resources Administration files, Maryland Geological Survey reports, county water and sewerage plans, and miscellaneous county reports)

\begin{tabular}{|c|c|c|c|c|c|c|c|c|}
\hline User & $\begin{array}{c}\text { Appropriation } \\
\text { number }\end{array}$ & Aquifer & $\begin{array}{l}\text { land grid } \\
\text { rdinates }\end{array}$ & 1980 & 1979 & 1978 & 1977 & $\overline{1976}$ \\
\hline ACME Markets, Incorporated & $59-004$ & Frederica & $\begin{array}{l}\text { N292 } \\
\text { E1126 }\end{array}$ & 0.265 & 0.342 & 0.335 & 0.250 & 0.429 \\
\hline Bloch and Gugsenheimer, Incorporated & $54-001$ & Quaternary & $\begin{array}{l}\text { N292 } \\
\text { E1128 }\end{array}$ & .190 & .190 & .190 & .190 & .190 \\
\hline $\begin{array}{l}\text { Bonnie Brook, Dorchester County } \\
\text { Sanitary District }\end{array}$ & $63-005$ & Piney Point & $\begin{array}{l}\text { N265 } \\
\text { E1081 }\end{array}$ & .020 & .019 & .019 & .019 & .019 \\
\hline Bumble Bee Corporation & $62-003$ & Piney Point & $\begin{array}{l}\text { N263 } \\
\text { E1067 }\end{array}$ & .000 & .000 & .000 & .000 & .074 \\
\hline Cambridge, City of & 71-005 & Magothy & $\begin{array}{l}\text { N264 } \\
\text { E1065 }\end{array}$ & .264 & .270 & .216 & .314 & .318 \\
\hline Cambridge, City of & $71-005$ & Piney Point & $\begin{array}{l}\text { N268 } \\
\text { E1067 }\end{array}$ & 1.727 & 1.881 & 2.283 & 1.900 & 2.108 \\
\hline Cambridge, City of & 71-005 & Patapsco & $\begin{array}{l}\text { N265 } \\
\text { E1067 }\end{array}$ & 1.007 & .860 & .594 & .769 & .363 \\
\hline Country Pride Foods, Incorporated & $71-003$ & Quaternary & $\begin{array}{l}\text { N293 } \\
\text { E1125 }\end{array}$ & .460 & .427 & .430 & .436 & .457 \\
\hline Crystal Ice and Cold Storage & $47-002$ & Magothy & $\begin{array}{l}\text { N269 } \\
\text { E1065 }\end{array}$ & .000 & .000 & .000 & .000 & .000 \\
\hline Crystal Ice and Cold Storage & 47-002 & Piney Point & $\begin{array}{l}\text { N269 } \\
\text { E1065 }\end{array}$ & .000 & .000 & .000 & .000 & .000 \\
\hline Dececco Corporation & $66-005$ & Quaternary & $\begin{array}{l}\text { N270 } \\
\text { E1134 }\end{array}$ & .030 & .030 & .030 & .030 & .030 \\
\hline Delmarva Power and Light Company & 55-001 & Federalsburg & $\begin{array}{l}\text { N242 } \\
\text { E1137 }\end{array}$ & .008 & .026 & .022 & .021 & .025 \\
\hline Delmarva Power and Light Company & $55-001$ & Quaternary & $\begin{array}{l}\text { N242 } \\
\text { E1138 }\end{array}$ & .033 & .066 & .056 & .054 & .065 \\
\hline East Coast Cold Storage & $62-007$ & Piney Point & $\begin{array}{l}\text { N265 } \\
\text { E1060 }\end{array}$ & .048 & .011 & .004 & .055 & .111 \\
\hline East New Market, Town of & $74-003$ & Calvert & $\begin{array}{l}\text { N280 } \\
\text { E1100 }\end{array}$ & .032 & .031 & .035 & .036 & .035 \\
\hline Banover Brands & $62-002$ & Piney Point & $\begin{array}{l}\text { N265 } \\
\text { E1060 }\end{array}$ & .004 & .005 & .004 & .006 & .098 \\
\hline Burlock Pickling Company & $61-002$ & Frederica & $\begin{array}{l}\text { N292 } \\
\text { E1120 }\end{array}$ & .000 & .000 & .000 & .000 & .000 \\
\hline Hurlock, Town of & $76-021$ & Frederica & $\begin{array}{l}\text { N291 } \\
\text { E1120 }\end{array}$ & .287 & .299 & .248 & .206 & .192 \\
\hline Secretary, Town of & $76-012$ & Piney Point & $\begin{array}{l}\text { N284 } \\
\text { E1100 }\end{array}$ & .081 & .076 & .081 & .041 & .027 \\
\hline Vienna, Town of & $79-004$ & Calvert & $\begin{array}{l}\text { N239 } \\
\text { E1130 }\end{array}$ & .068 & .061 & .060 & .058 & .055 \\
\hline Walter T. Andrews and Son & $53-002$ & Piney Point & $\begin{array}{l}\text { N262 } \\
\text { E1060 }\end{array}$ & .000 & .000 & .009 & .026 & .018 \\
\hline
\end{tabular}




\begin{tabular}{|c|c|c|c|c|c|c|c|c|c|c|c|}
\hline 1975 & 1974 & 1973 & 1972 & 1971 & 1970 & $1960-69$ & $1950-59$ & $1940-49$ & $1930-39$ & $1920-29$ & $1900-19$ \\
\hline 0.426 & 0.490 & 0.404 & 0.306 & 0.276 & 0.247 & 0.238 & 0.160 & 0.000 & 0.000 & $\begin{array}{l}0.000 \\
\text { First pumpage: }\end{array}$ & $\begin{array}{l}0.000 \\
1954\end{array}$ \\
\hline .190 & .190 & .190 & .190 & .190 & .190 & .190 & .190 & .000 & .000 & First $\stackrel{.000}{\text { pumpage: }}$ & 1950 \\
\hline .019 & .019 & .017 & .017 & .017 & .015 & .014 & .000 & .000 & .000 & First pumpage: & 1961 \\
\hline .068 & .087 & .110 & .110 & .110 & .145 & .230 & .439 & .000 & .000 & First $\stackrel{.000}{\text { pumpage : }}$ & 1952 \\
\hline .307 & .343 & .375 & .262 & .328 & .467 & .398 & .434 & .162 & .000 & $\begin{array}{l}.000 \\
\text { First pumpage: }\end{array}$ & $=1945$ \\
\hline 2.227 & 2.587 & 2.467 & 2.519 & 2.570 & 3.164 & 2.634 & 2.849 & 2.266 & 1.305 & First purmpage: & $?^{.644}$ \\
\hline .465 & .178 & .175 & .209 & .217 & .000 & .000 & .000 & .000 & .000 & First $\stackrel{.000}{\text { pumpage: }}$ & 1971 \\
\hline .438 & .516 & .496 & .304 & .256 & .000 & .000 & .000 & .000 & .000 & First pumpage: & $: .000$ \\
\hline .000 & .000 & .000 & .000 & .000 & .075 & .075 & .075 & .075 & .075 & First pumpage: & $: .000$ \\
\hline .000 & .000 & .000 & .000 & .000 & .075 & .075 & .075 & .075 & .075 & First $\stackrel{.075}{\text { pumpage : }}$ & $: .000$ \\
\hline .027 & .026 & .026 & .026 & .025 & .023 & .022 & .000 & .000 & .000 & First $\stackrel{.000}{\text { pumpage }}$ & 1.000 \\
\hline .018 & .016 & .015 & .018 & .000 & .000 & .000 & .000 & .000 & .000 & First pumpage: & $: 1972$ \\
\hline .046 & .041 & .039 & .045 & .000 & .000 & .000 & .000 & .000 & .000 & First pumpage: & $: .000$ \\
\hline .077 & .060 & .083 & .088 & .140 & .205 & .218 & .219 & .219 & .000 & First $\stackrel{.000}{\text { pumpage }}$ & $: 1946$ \\
\hline .035 & .036 & .035 & .035 & .035 & .035 & .031 & .031 & .033 & .030 & First $\stackrel{.027}{\text { pumpage : }}$ & $: \dot{027}$ \\
\hline .128 & .196 & .235 & .235 & .235 & .251 & .276 & .295 & .001 & .000 & First $\stackrel{.000}{\text { pumpage }}$ & $: 1952$ \\
\hline .000 & .000 & .000 & .054 & .054 & .054 & .054 & .054 & .000 & .000 & First $\stackrel{.000}{\text { pumpage: }}$ & $: .000$ \\
\hline .178 & .164 & .151 & .137 & .137 & .132 & .131 & .125 & .106 & .097 & First pumpage: & $: \frac{.042}{?}$ \\
\hline .027 & .065 & .026 & .026 & .026 & .030 & .039 & .039 & .038 & .038 & First pumpage: & $?_{?}^{.025}$ \\
\hline .052 & .049 & .048 & .047 & .045 & .045 & .048 & .052 & .046 & .035 & First pumpage: & $: .027$ \\
\hline .017 & .024 & .024 & .004 & .004 & .004 & .000 & .000 & .000 & .000 & First pumpage: & $: .000$ \\
\hline
\end{tabular}


Ground-water withdrawals by large users in the Coastal Plain area of Barford Count, 1900 through 1980

(Sources: Maryland Water Resources Administration files, Maryland Geological Survey reports, county water and sewerage plans, and miscellaneous county reports)

\begin{tabular}{|c|c|c|c|c|c|c|c|c|}
\hline User & $\begin{array}{l}\text { Appropriation } \\
\text { number }\end{array}$ & Aquifer & $\begin{array}{l}\text { yland grid } \\
\text { ordinates }\end{array}$ & 1980 & 1979 & 1978 & 1977 & 1976 \\
\hline Aberdeen, Town of & $77-022$ & Quaternary & $\begin{array}{l}\text { N606 } \\
\text { E1035 }\end{array}$ & 0.984 & 0.971 & 1.112 & 1.041 & 1.041 \\
\hline $\begin{array}{l}\text { Aberdeen Proving Ground (Aberdeen } \\
\text { wells) }\end{array}$ & $78-058$ & Talbot & $\begin{array}{l}\text { N568 } \\
\text { E1013 }\end{array}$ & .017 & .016 & .022 & .028 & .035 \\
\hline $\begin{array}{l}\text { Aberdeen Proving Ground (Edgewood } \\
\text { wells) }\end{array}$ & $78-060$ & Talbot & $\begin{array}{l}\text { N546 } \\
\text { E1000 }\end{array}$ & .016 & .016 & .023 & .030 & .037 \\
\hline Bata Shoe Company, Incorporated & $52-002$ & Talbot & $\begin{array}{l}\text { N596 } \\
\text { E1015 }\end{array}$ & .018 & .027 & .027 & .026 & .025 \\
\hline $\begin{array}{l}\text { F.o. Mitchell and Brothers Canning } \\
\text { Incorporated }\end{array}$ & $47-003$ & Ta1bot & $\begin{array}{l}\text { N597 } \\
\text { E1024 }\end{array}$ & .004 & .007 & .005 & .010 & .011 \\
\hline Interpace Corporation & $56-007$ & Potomac Group & $\begin{array}{l}\text { N595 } \\
\text { E1025 }\end{array}$ & .099 & .120 & .132 & .101 & .105 \\
\hline J.M. Huber Corporation & $47-001$ & Talbot & $\begin{array}{l}\text { N625 } \\
\text { E1054 }\end{array}$ & .178 & .184 & .176 & .111 & .113 \\
\hline $\begin{array}{l}\text { Long Bar Harbor, Harford County } \\
\text { Department of Public Works }\end{array}$ & $66-012$ & Potomac Group & $\begin{array}{l}\text { N594 } \\
\text { E1011 }\end{array}$ & .107 & .134 & .107 & .000 & .001 \\
\hline Joppatowne Utilities & $63-013$ & Potomac Group & $\begin{array}{l}\text { N575 } \\
\text { E985 }\end{array}$ & .259 & .433 & .296 & .335 & .318 \\
\hline $\begin{array}{l}\text { Perryman wells, Harford County } \\
\text { Department of Public Works }\end{array}$ & $69-003$ & Potomac Group & $\begin{array}{l}\text { N596 } \\
\text { E1025 }\end{array}$ & 1.130 & 1.150 & 1.097 & .981 & 2.321 \\
\hline $\begin{array}{l}\text { Short Lane wells, Harford County } \\
\text { Department of Public Works }\end{array}$ & $69-025$ & Potomac Group & $\begin{array}{l}\text { N595 } \\
\text { E1027 }\end{array}$ & 1.778 & 1.826 & 1.504 & 2.181 & 1.096 \\
\hline Willoughby Beach Water Company & None & Potomac Group & $\begin{array}{l}\text { N586 } \\
\text { E1011 }\end{array}$ & .038 & .038 & .038 & .038 & .038 \\
\hline
\end{tabular}

Ground-water withdrawals by Large users in Kent Counts. 1900 through 1980

(Sources: Maryland Water Resources Administration files, Maryland Geological Survey reports, county water and sewerage plans, and miscellaneous county reports)

\begin{tabular}{|c|c|c|c|c|c|c|c|c|c|}
\hline User & $\begin{array}{l}\text { Appropriation } \\
\text { number }\end{array}$ & Aquifer & $\begin{array}{l}\text { Marylalnd grid } \\
\text { coordinates }\end{array}$ & 1 & 1980 & 1979 & 1978 & 1977 & 1976 \\
\hline Betterton, Town of & $79-002$ & Magothy & $\begin{array}{l}\text { N560 } \\
\text { E1065 }\end{array}$ & & 0.016 & 0.015 & 0.015 & 0.015 & 0.015 \\
\hline $\begin{array}{l}\text { C. H. Ashley \& Son Oyster } \\
\text { Company }\end{array}$ & $55-001$ & Aquia & $\begin{array}{l}\text { N467 } \\
\text { E1028 }\end{array}$ & & .000 & .000 & .000 & .000 & .000 \\
\hline Camp Tockwogh & $67-001$ & Patapsco & $\begin{array}{l}\text { N556 } \\
\text { E1048 }\end{array}$ & & .004 & .004 & .011 & .004 & .004 \\
\hline Campbell Soup Company & $59-003$ & Aquia & $\begin{array}{l}\text { N515 } \\
\text { E1075 }\end{array}$ & & .580 & .561 & .649 & .667 & .644 \\
\hline Chestertown Utilities Commission & $70-004$ & Aquia & $\begin{array}{l}\text { N504 } \\
\text { E1065 }\end{array}$ & & .505 & .544 & .473 & .486 & .479 \\
\hline Chestertown Utilities Commission & $70-004$ & Patapsco & $\begin{array}{l}\text { N504 } \\
\text { E1065 }\end{array}$ & & .000 & .000 & .000 & .000 & .000 \\
\hline $\begin{array}{l}\text { Fairlee District, Kent County } \\
\text { Sanitary District }\end{array}$ & $79-004$ & Magothy & $\begin{array}{l}\text { N507 } \\
\text { E1035 }\end{array}$ & 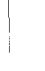 & .038 & .032 & .029 & .026 & .023 \\
\hline Galena, Town of & $71-003$ & Magothy & $\begin{array}{l}\text { N551 } \\
\text { E1118 }\end{array}$ & । & .037 & .040 & .040 & .043 & .041 \\
\hline Ivens \& Hudson Oyster Company & $46-002$ & Magothy & $\begin{array}{l}\text { N476 } \\
\text { E1012 }\end{array}$ & & .000 & .000 & .000 & .000 & .000 \\
\hline $\begin{array}{l}\text { Kennedyrille, Kent Co. Sanitary } \\
\text { District }\end{array}$ & $67-008$ & Severn & $\begin{array}{l}\text { N538 } \\
\text { E1084 }\end{array}$ & & .012 & .012 & .012 & .008 & .008 \\
\hline Kent Packing Company & $48-001$ & Magothy & $\begin{array}{l}\text { N475 } \\
\text { E1018 }\end{array}$ & & .000 & .000 & .000 & .000 & .000 \\
\hline Tenneco Chemicals Incorporated & $59-002$ & Magothy & $\begin{array}{l}\text { N521 } \\
\text { E1058 }\end{array}$ & ! & .067 & .076 & .068 & .088 & .088 \\
\hline Rock Hall, Town of & $71-004$ & Patapsco & $\begin{array}{l}\text { N476 } \\
\text { E1016 }\end{array}$ & & .153 & .175 & .163 & .141 & .136 \\
\hline Vita Food Products, Incorporated & $54-001$ & Magothy & $\begin{array}{l}\text { N504 } \\
\text { E1062 }\end{array}$ & & .000 & .000 & .000 & .000 & .000 \\
\hline
\end{tabular}




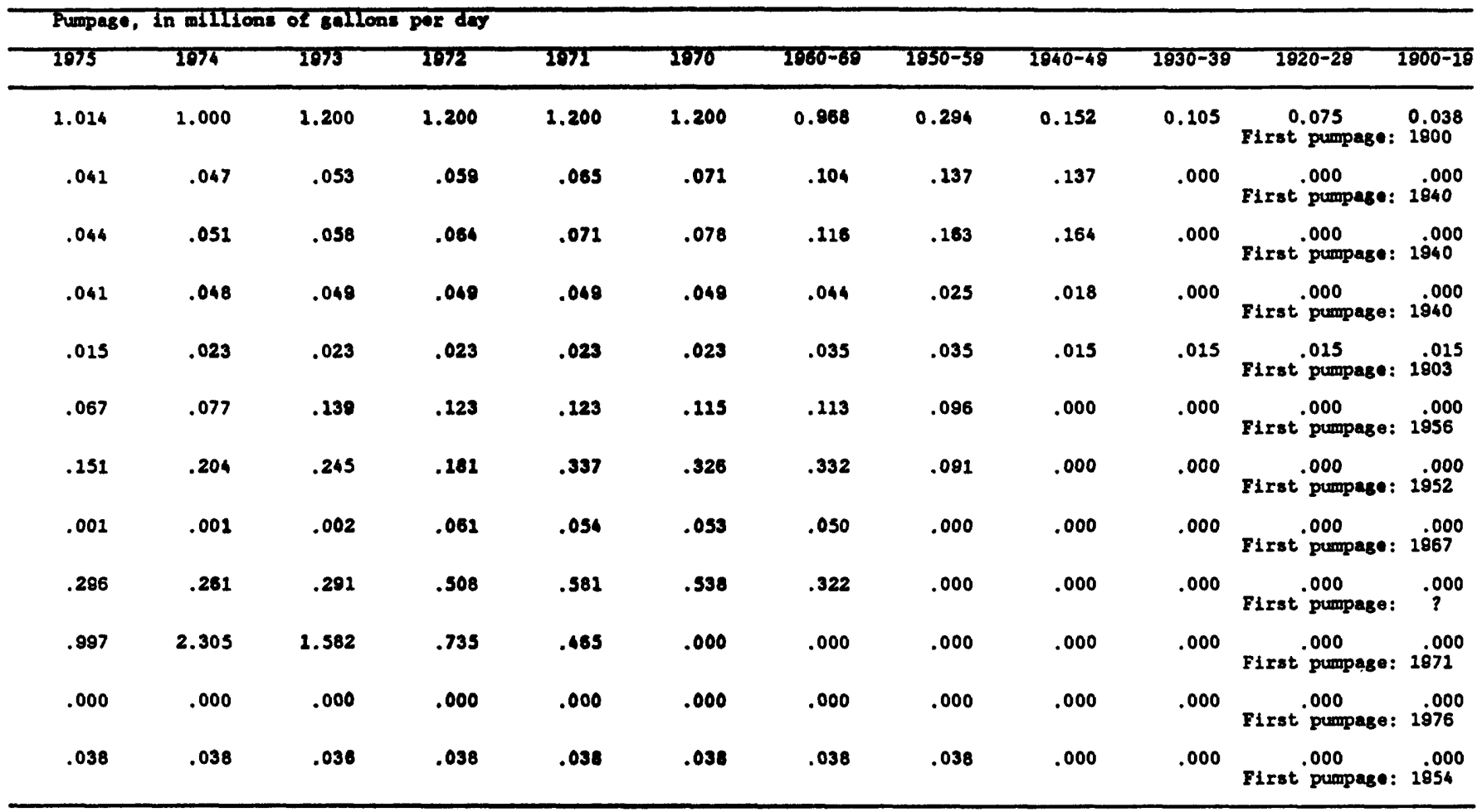

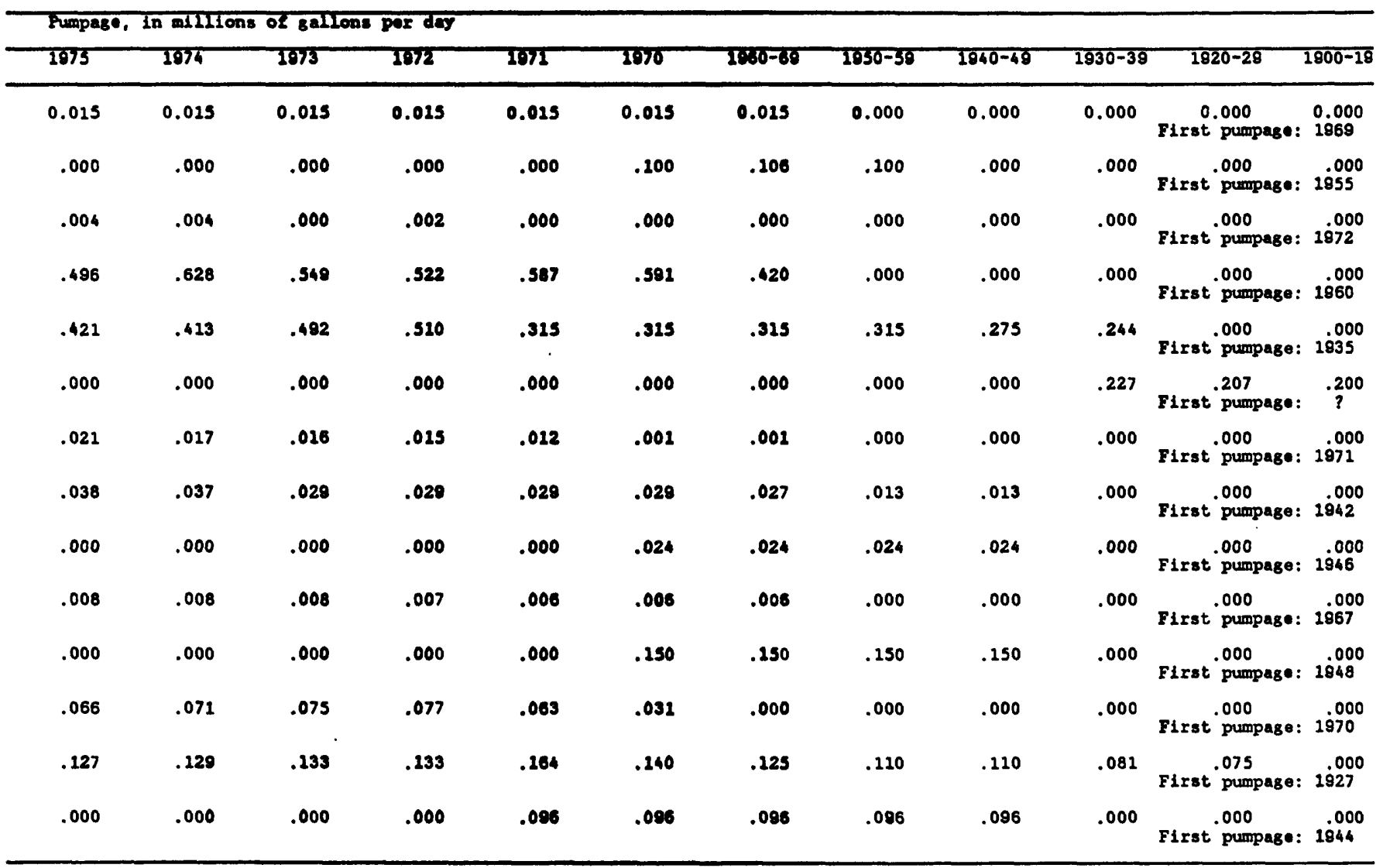


Ground-water withdrawals by large users in the Coastal Plain aree of Prince Georges Coumty. 1900 through 1980

(Sources: Maryland Water Resources Administration files, Maryland Geological Survey reports, county water and sewerage plans, and miscellaneous county reports)

\begin{tabular}{|c|c|c|c|c|c|c|c|c|}
\hline User & $\begin{array}{c}\text { Appropriation } \\
\text { number }\end{array}$ & Aquifer & $\begin{array}{l}\text { Maryland grid } \\
\text { coordinates }\end{array}$ & 1980 & 1979 & 1978 & 1977 & 1976 \\
\hline BFW Fabrication Company & $65-005$ & Magothy & $\begin{array}{l}\text { K309 } \\
\mathbf{E 8 5 3}\end{array}$ & 0.001 & 0.001 & 0.004 & 0.010 & 0.010 \\
\hline Bowie, City of & $61-008$ & Magothy & $\begin{array}{l}N 413 \\
E 876\end{array}$ & .235 & .121 & .175 & .152 & .230 \\
\hline Bowie, City of & $61-008$ & Patapsco & $\begin{array}{l}\text { N413 } \\
\mathbf{E} 876\end{array}$ & .164 & .811 & 1.228 & 1.240 & 1.281 \\
\hline Bowie, City of & $61-008$ & Patuxent & $\begin{array}{l}\text { K413 } \\
\text { E878 }\end{array}$ & 2.075 & 1.476 & 1.054 & 1.172 & 1.072 \\
\hline Boy's Village & $56-007$ & Magothy & $\begin{array}{l}\text { N329 } \\
\text { E846 }\end{array}$ & .112 & .116 & .090 & .101 & .082 \\
\hline Brandywine Country Club & $71-002$ & Magothy & $\begin{array}{l}\text { N333 } \\
\text { E864 }\end{array}$ & .000 & .000 & .000 & .000 & .000 \\
\hline Calvert Menor Corporation & 55-011 & Patapsco & $\begin{array}{l}\text { N310 } \\
\text { E798 }\end{array}$ & .019 & .016 & .020 & .019 & .019 \\
\hline Cedar Ridge Company & $51-003$ & Patapsco & $\begin{array}{l}11347 \\
E 800\end{array}$ & .022 & .021 & .028 & .027 & .029 \\
\hline Cedarville Park, Incorporated & 63-006 & Magothy & $\begin{array}{l}\mathbf{N 3 0 0} \\
\mathbf{E 8 5 0}\end{array}$ & .044 & .045 & .047 & .049 & .055 \\
\hline $\begin{array}{l}\text { First Maryland Utilities, } \\
\text { Incorporated }\end{array}$ & $63-003$ & Magothy & $\begin{array}{l}\text { K366 } \\
\mathbf{E 8 7 9}\end{array}$ & .183 & .187 & .193 & .115 & .187 \\
\hline $\begin{array}{l}\text { Forest Heights, Washington } \\
\text { Suburban Sanitary Comission }\end{array}$ & $74-017$ & Patuxent & $\begin{array}{l}\text { N358 } \\
\text { E799 }\end{array}$ & .000 & .000 & .000 & .000 & .000 \\
\hline $\begin{array}{l}\text { Fort Foote, Washington Suburban } \\
\text { Sanitary Comission }\end{array}$ & $74-018$ & Patapsco & $\begin{array}{l}\text { N340 } \\
\text { E795 }\end{array}$ & .000 & .000 & .000 & .000 & .000 \\
\hline Fort Washington & None & Patapsco & $\begin{array}{l}\text { N318 } \\
\text { E794 }\end{array}$ & .000 & .000 & .000 & .000 & .000 \\
\hline Fort Washington & None & Patuxent & $\begin{array}{l}\text { N318 } \\
\text { E794 }\end{array}$ & .000 & .000 & .000 & .000 & .000 \\
\hline Greenbelt Comsumer Service & $47-002$ & Patuxent & $\begin{array}{l}\text { N426 } \\
E 836\end{array}$ & .002 & .002 & .000 & .000 & .000 \\
\hline Lone Star Industries, Incorporated & $59-001$ & Magothy & $\begin{array}{l}\text { N356 } \\
\text { E843 }\end{array}$ & .000 & .000 & .000 & .003 & .008 \\
\hline $\begin{array}{l}\text { Maryland National Capital Park and } \\
\text { Planning Commission }\end{array}$ & $70-006$ & Patapsco & $\begin{array}{l}\text { N384 } \\
\text { E858 }\end{array}$ & .005 & .010 & .007 & .005 & .003 \\
\hline Mineral Pigments Corporation & None & Patuxent & $\begin{array}{l}N 449 \\
\text { E829 }\end{array}$ & .000 & .000 & .000 & .000 & .000 \\
\hline $\begin{array}{l}\text { Morningside Village and Gwynn } \\
\text { Subdivision }\end{array}$ & 49-006 & Patapsco & $\begin{array}{l}\text { N364 } \\
\text { E830 }\end{array}$ & .000 & .000 & .000 & .000 & .000 \\
\hline $\begin{array}{l}\text { Northeast Marlboro water } \\
\text { system }\end{array}$ & $47-003$ & Magothy & $\begin{array}{l}\text { N361 } \\
\text { E871 }\end{array}$ & .002 & .002 & .002 & .012 & .014 \\
\hline $\begin{array}{l}\text { Patuxent Wildiffe Research } \\
\text { Rsfuge }\end{array}$ & 58-003 & Patuxent & $\begin{array}{l}\text { N443 } \\
\text { E856 }\end{array}$ & .164 & .137 & .141 & .080 & .000 \\
\hline $\begin{array}{l}\text { Patuxent Wildilfe Research } \\
\text { Refuge }\end{array}$ & $58-003$ & Patapsco & $\begin{array}{l}\text { N443 } \\
\text { E856 }\end{array}$ & .000 & .014 & .027 & .070 & .070 \\
\hline PEPCO, Chalk Point & $62-007$ & Magothy & $\begin{array}{l}\text { K259 } \\
\text { E892 }\end{array}$ & .776 & .671 & .695 & .685 & .945 \\
\hline PEPCo, Chalk Point & $62-007$ & Patapsco & $\begin{array}{l}\text { N259 } \\
\mathbf{E 8 9 2}\end{array}$ & .298 & .304 & .345 & .189 & .173 \\
\hline Potomac Vista Corporation & $52-004$ & Patapsco & $\begin{array}{l}\text { N347 } \\
\text { E797 }\end{array}$ & .015 & .011 & .011 & .000 & .000 \\
\hline Safeway Stores, Incorporated & $55-005$ & Magothy & $\begin{array}{l}1347 \\
\text { E858 }\end{array}$ & .000 & .000 & .000 & .010 & .010 \\
\hline Simpson Land Company, Incorporated & $61-005$ & Magothy & $\begin{array}{l}N 407 \\
\mathbf{E 8 7 9}\end{array}$ & .014 & .015 & .011 & .012 & .012 \\
\hline
\end{tabular}




\begin{tabular}{|c|c|c|c|c|c|c|c|c|c|c|c|}
\hline 1975 & 1974 & 1973 & 1972 & 1971 & 1970 & $1960-69$ & $1950-59$ & $1940-49$ & $1930-39$ & $1920-29$ & $1900-19$ \\
\hline 0.010 & 0.010 & 0.010 & 0.010 & 0.010 & 0.010 & 0.010 & 0.000 & 0.000 & 0.000 & $\begin{array}{c}0.000 \\
\text { First pumpage: }\end{array}$ & $\begin{array}{l}0.000 \\
1963\end{array}$ \\
\hline .254 & .171 & .195 & .353 & .478 & .268 & .184 & .000 & .000 & .000 & First $\stackrel{.000}{\text { pumpage: }}$ & 19002 \\
\hline 1.131 & 1.158 & 1.104 & .874 & 1.409 & .994 & .710 & .000 & .000 & .000 & First $\stackrel{.000}{\text { pumpage: }}$ & 19000 \\
\hline 1.124 & 1.268 & 1.395 & 1.445 & .852 & 1.420 & 1.049 & .000 & .000 & .000 & First $\stackrel{.000}{\text { pumpage: }}$ & 1965 \\
\hline .082 & .082 & .082 & .082 & .096 & .110 & .149 & .069 & .027 & .017 & First pumpage: & 19008 \\
\hline .000 & .000 & .000 & .020 & .019 & .000 & .000 & .000 & .000 & .000 & First $\stackrel{.000}{\text { pumpage: }}$ & 19000 \\
\hline .018 & .018 & .017 & .017 & .014 & .004 & .004 & .003 & .000 & .000 & First $\stackrel{.000}{\text { pumpage: }}$ & 1900 \\
\hline .030 & .031 & .032 & .033 & .000 & .000 & .000 & .000 & .000 & .000 & First $\stackrel{.000}{\text { pumpage: }}$ & 1972 \\
\hline .058 & .058 & .058 & .058 & .058 & .058 & .058 & .055 & .000 & .000 & First $\stackrel{.000}{\text { pumpage: }}$ & 1950 \\
\hline .175 & .145 & .127 & .119 & .096 & .060 & .034 & .000 & .000 & .000 & First $\stackrel{.000}{\text { pumpage : }}$ & 1969 \\
\hline .000 & .000 & .000 & .490 & .479 & .466 & .423 & .324 & .158 & .000 & First $\stackrel{.000}{\text { pumpage: }}$ & 19000 \\
\hline .000 & .000 & .233 & .477 & .467 & .675 & .620 & .397 & .000 & .000 & First $\stackrel{.000}{\text { pumpage: }}$ & 19000 \\
\hline .000 & .000 & .000 & .000 & .000 & .000 & .022 & .018 & .010 & .010 & First pumpage: & 19010 \\
\hline .000 & .000 & .000 & .000 & .000 & .000 & .033 & .023 & .007 & .000 & First $\stackrel{.000}{\text { pumpage }}$ & $: 1940$ \\
\hline .000 & .000 & .000 & .000 & .000 & .000 & .000 & .100 & .100 & .000 & First $\stackrel{.000}{\text { pumpage: }}$ & $\begin{array}{c}.000 \\
1948\end{array}$ \\
\hline .017 & .014 & .015 & .016 & .013 & .015 & .017 & .000 & .000 & .000 & First $\stackrel{.000}{\text { pumpage: }}$ & 19000 \\
\hline .002 & .001 & .002 & .003 & .002 & .000 & .000 & .000 & .000 & .000 & First pumpage: & $: \quad .000$ \\
\hline .000 & .000 & .000 & .000 & .000 & .000 & .068 & .056 & .034 & .000 & First pumpage: & $=1.000$ \\
\hline .000 & .000 & .000 & .000 & .000 & .000 & .000 & .100 & .044 & .000 & First pumpage: & $: 1941$ \\
\hline .013 & .013 & .012 & .010 & .018 & .011 & .012 & .013 & .000 & .000 & First $\stackrel{.000}{\text { pumpage: }}$ & 1950 \\
\hline .000 & .000 & .000 & .000 & .000 & .000 & .000 & .000 & .000 & .000 & Flrst pumpage: & $=?$ \\
\hline .070 & .070 & .070 & .070 & .070 & .070 & .070 & .000 & .000 & .000 & First $\stackrel{.000}{\text { pumpage: }}$ & $=\frac{.000}{?}$ \\
\hline .748 & .501 & .440 & .482 & .487 & .477 & .317 & .000 & .000 & .000 & Flrst $\stackrel{.000}{\text { pumpage: }}$ & $: 1960$ \\
\hline .158 & .000 & .000 & .000 & .000 & .000 & .000 & .000 & .000 & .000 & Flrst $\stackrel{.000}{\text { pumpage: }}$ & 19000 \\
\hline .000 & .000 & .000 & .000 & .000 & .000 & .000 & .000 & .000 & .000 & First $\stackrel{.000}{\text { pumpage: }}$ & $: 1978$ \\
\hline .002 & .002 & .003 & .012 & .012 & .012 & .011 & .001 & .000 & .000 & First $\stackrel{.000}{\text { pumpage: }}$ & 1855 \\
\hline .012 & .012 & .012 & .012 & .012 & .012 & .012 & .000 & .000 & .000 & Flrst .000 & $: .000$ \\
\hline
\end{tabular}




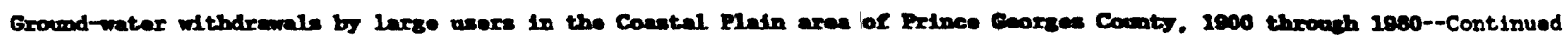

\begin{tabular}{|c|c|c|c|c|c|c|c|c|}
\hline User & $\begin{array}{l}\text { Appropriation } \\
\text { number }\end{array}$ & Aquifer & $\begin{array}{l}\text { Lend grid } \\
\text { ordinetes }\end{array}$ & 1880 & 1979 & 1878 & 1977 & 1876 \\
\hline $\begin{array}{l}\text { U.S. Depertment of Agriculture, } \\
\text { Beltsville }\end{array}$ & $66-012$ & Paturent & $\begin{array}{l}\text { K440 } \\
\text { E836 }\end{array}$ & 0.607 & 0.573 & 0.625 & 0.705 & 0.715 \\
\hline $\begin{array}{l}\text { U.S. Haval Research Laboratory, } \\
\text { Brandywine }\end{array}$ & $65-008$ & Petapsco & $\begin{array}{l}17308 \\
\mathbf{E 8 4 2}\end{array}$ & .014 & .030 & .030 & .030 & .030 \\
\hline $\begin{array}{l}\text { Upper Marlboro, Washington } \\
\text { Suburban Sanitary Commission }\end{array}$ & $70-002$ & Magothy & $\begin{array}{l}\mathrm{N349} \\
\mathrm{E878}\end{array}$ & .021 & .017 & .015 & .041 & .057 \\
\hline U.S. Air Force Country Club & $32-001$ & Potomac Group & $\begin{array}{l}\text { N319 } \\
\text { E865 }\end{array}$ & .000 & .000 & .000 & .000 & .000 \\
\hline U.S. Navy, Cheltenham & None & Magothy & $\begin{array}{l}\mathbf{R 3 3 4} \\
\mathbf{E 8 4 1}\end{array}$ & .060 & .060 & .060 & .060 & .060 \\
\hline Washington Gas Light Company & $57-014$ & Potonac Group & $\begin{array}{l}\mathbf{1 3 2 0} \\
\mathbf{E} 832\end{array}$ & .000 & .000 & .000 & .000 & .000 \\
\hline W11lie G. Sauerwein & $53-006$ & Magothy & $\begin{array}{l}\text { N355 } \\
\mathbf{E 8 8 0}\end{array}$ & .007 & .005 & .008 & .008 & .010 \\
\hline
\end{tabular}

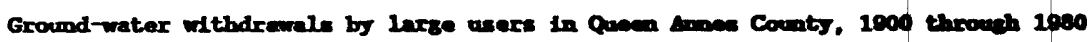

(Sources: Maryland Water Resources Administration flles, Maryland Geological Survey reports, county water and sewerage plans, and miscellaneous county roports)

\begin{tabular}{|c|c|c|c|c|c|c|c|c|}
\hline User & $\begin{array}{l}\text { Appropriation } \\
\text { number }\end{array}$ & Aquifer & $\begin{array}{l}\text { Maryland grid } \\
\text { coordinates }\end{array}$ & 1980 & 1979 & 1978 & 1977 & 1976 \\
\hline Centrevil1e, Town of . & $67-002$ & Aquia & $\begin{array}{l}1443 \\
\mathbf{E} 1060\end{array}$ & 0.132 & 0.133 & 0.132 & 0.135 & 0.133 \\
\hline Centreville, Town of & $67-002$ & Severm & $\begin{array}{l}\mathbf{1 4 4 3} \\
\mathbf{E} 1068\end{array}$ & .329 & .331 & .329 & .337 & .333 \\
\hline $\begin{array}{l}\text { Chesapeake Bay Model Shelter, } \\
\text { U.S. Army Corps of Engineer. }\end{array}$ & $74-008$ & Magothy & $\begin{array}{l}11412 \\
2085\end{array}$ & .043 & .071 & .065 & .060 & .053 \\
\hline Country Pride Foods, Queenstom & $69-003$ & Aquila & $\begin{array}{l}120 \\
1052\end{array}$ & .016 & .013 & .003 & .003 & .002 \\
\hline Jenkins Food Corporation & $60-005$ & Aquila & $\begin{array}{l}462 \\
1096\end{array}$ & .000 & .039 & .024 & .033 & .050 \\
\hline Jenkins Food Corporation & $60-005$ & Quaternary & $\begin{array}{l}1 / 482 \\
\mathbf{2 1 0 9 8}\end{array}$ & .000 & .010 & .008 & .008 & .013 \\
\hline $\begin{array}{l}\text { Maryland Department of Correction, } \\
\text { Eastern Pre-Release Unit }\end{array}$ & $63-002$ & Aquia & $\begin{array}{l}1468 \\
\$ 1086\end{array}$ & .018 & .000 & .000 & .000 & .000 \\
\hline $\begin{array}{l}\text { Millington, Town of (sewage treatment } \\
\text { plant) }\end{array}$ & $66-013$ & Aguia & $\begin{array}{l}\mathbf{H} 521 \\
\mathbf{E} 1128\end{array}$ & .012 & .012 & .012 & .011 & .011 \\
\hline Princetion Turf Farms, Incorporated & $71-010$ & Aguia & $\begin{array}{l}\$ 423 \\
\text { B1054 }\end{array}$ & .000 & .000 & .000 & .029 & .027 \\
\hline Prospect Plantation Golf Course & $76-003$ & Aquia & $\begin{array}{l}\mathbf{1 3 9 2} \\
\mathrm{E} 1029\end{array}$ & .022 & .002 & .000 & .000 & .000 \\
\hline Queenstown, Town of & $78-010$ & Aquia & $\begin{array}{l}1423 \\
21040\end{array}$ & .044 & .000 & .000 & .000 & .000 \\
\hline S.E.W. Friel Cannery, Queenstom & $71-007$ & Chesmold & $\begin{array}{l}\text { K421 } \\
\text { E } 1041\end{array}$ & .016 & .012 & .015 & .008 & .020 \\
\hline S.E.W. Friel Cannery, Queenstown & $71-007$ & Aquia & $\begin{array}{l}1421 \\
1041\end{array}$ & .032 & .023 & .028 & .028 & .038 \\
\hline S.E.W. Friel Cannery, Wye Mills & $56-001$ & Aquia & $\begin{array}{l}\text { Ph10 } \\
\text { E1067 }\end{array}$ & .105 & .098 & .128 & .113 & .083 \\
\hline Stevens Village Utility Company & $70-002$ & Aquia & $\begin{array}{l}017 \\
5904\end{array}$ & .032 & .020 & .018 & .014 & .011 \\
\hline
\end{tabular}




\begin{tabular}{|c|c|c|c|c|c|c|c|c|c|c|c|}
\hline 1975 & 1974 & 1973 & 1972 & 1971 & 1970 & $1960-69$ & $1950-59$ & $1940-49$ & $1930-39$ & $1920-29$ & $1900-19$ \\
\hline 0.731 & 0.779 & 0.788 & 0.780 & 0.764 & 0.696 & 0.559 & 0.002 & 0.000 & 0.000 & $\begin{array}{l}0.000 \\
\text { First purmpage: }\end{array}$ & $: \begin{array}{c}0.000 \\
?\end{array}$ \\
\hline .030 & .030 & .030 & .030 & .030 & .030 & .000 & .000 & .000 & .000 & First pumpage: & $: 1970$ \\
\hline .073 & .102 & .054 & .046 & .048 & .050 & .051 & .089 & .125 & .000 & First pumpage: & $: 1900$ \\
\hline .056 & .055 & .065 & .066 & .068 & .082 & .144 & .253 & .330 & .171 & First pumpage: & $: .000$ \\
\hline .000 & .000 & .000 & .000 & .000 & .000 & .000 & .026 & .000 & .000 & First pumpage: & $: \frac{.000}{?}$ \\
\hline .011 & .011 & .012 & .011 & .008 & .011 & .011 & .011 & .000 & .000 & F1rst pumpage: & $: .000$ \\
\hline
\end{tabular}

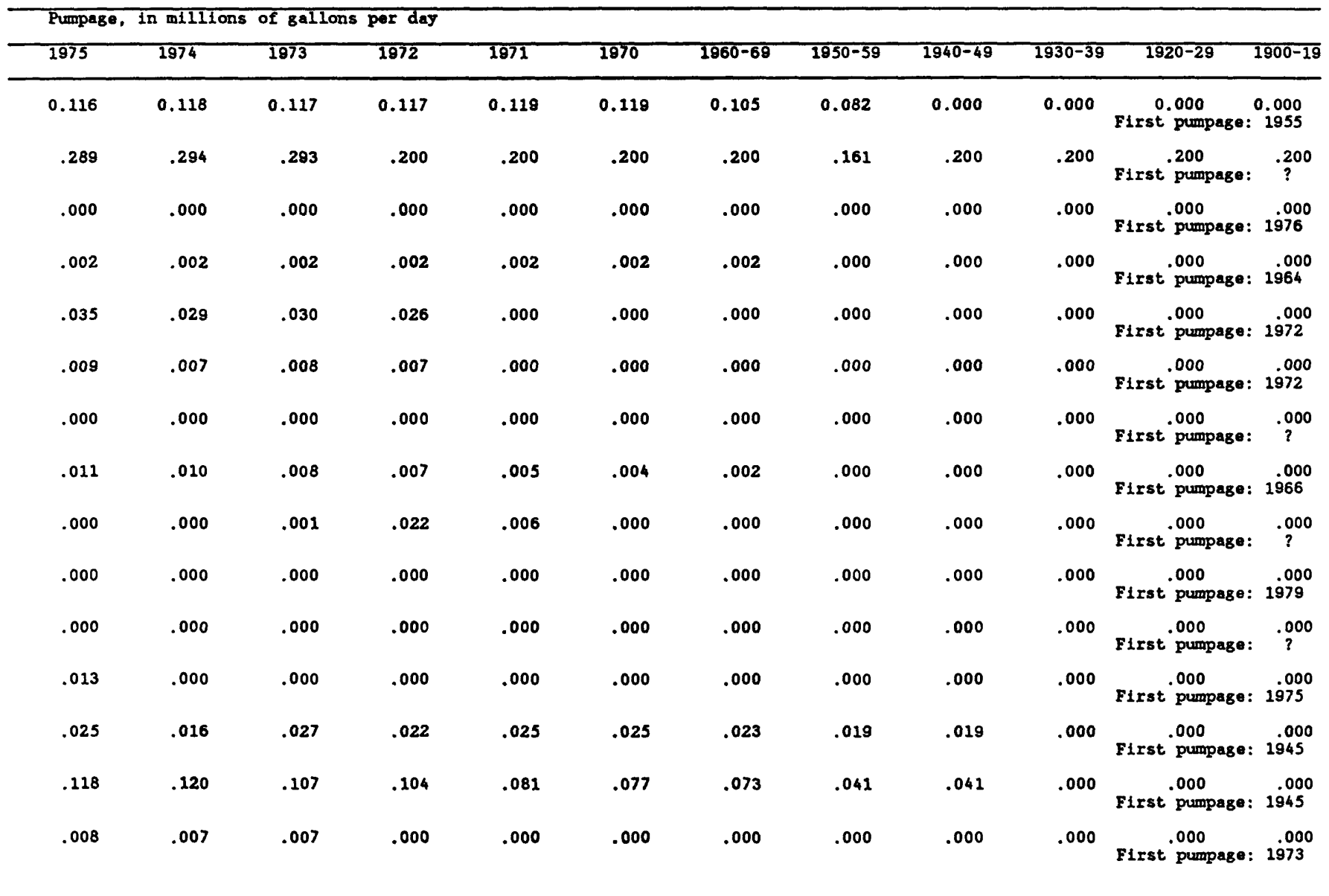


Ground-water withdrawals by large weers in St. Haxy Counts. 1900 through 19,80

(Sources: Maryland Water Resources Administration files, Maryland Geological Survey reports, county water and sewerage plans, and miscellaneous county reports)

\begin{tabular}{|c|c|c|c|c|c|c|c|c|}
\hline User & $\begin{array}{l}\text { Appropriation } \\
\text { number }\end{array}$ & Aquifer & $\begin{array}{l}\text { Maryland grid } \\
\text { coordinates }\end{array}$ & 1980 & 1979 & 1978 & 1977 & 1976 \\
\hline $\begin{array}{l}\text { Birch Manor, St. Marys Metropolitan } \\
\text { Commission }\end{array}$ & $74-035$ & Aqui a & $\begin{array}{l}\text { N211 } \\
\text { E880 }\end{array}$ & 0.024 & 0.023 & 0.019 & 0.017 & 0.011 \\
\hline $\begin{array}{l}\text { Cedar Cove, St. Marys Metropolitan } \\
\text { Comission }\end{array}$ & 73-003 & Aquia & $\begin{array}{l}\text { K155 } \\
\text { E967 }\end{array}$ & .047 & .039 & .040 & .060 & .074 \\
\hline Chance Water Company & $56-006$ & Piney Point & $\begin{array}{l}\text { K158 } \\
\text { E946 }\end{array}$ & .010 & .011 & .011 & .011 & .011 \\
\hline Cherry Cove Water Company & $69-017$ & Aquia & $\begin{array}{l}\text { K158 } \\
\text { E896 }\end{array}$ & .065 & .038 & .037 & .041 & .049 \\
\hline $\begin{array}{l}\text { Country Lakes, St. Marys } \\
\text { Metropolitan Commission }\end{array}$ & $76-003$ & Aquia & $\begin{array}{l}\text { N208 } \\
\text { E864 }\end{array}$ & .028 & .022 & .017 & $.004^{\circ}$ & .003 \\
\hline $\begin{array}{l}\text { Fenwick Manor, St. Marys } \\
\text { Metropolltan Commission }\end{array}$ & $74-043$ & Aquia & $\begin{array}{l}\text { N188 } \\
\text { E926 }\end{array}$ & .020 & .009 & .005 & .002 & .008 \\
\hline Green Acres Drive-In, Incorporated & $76-024$ & Aquia & $\begin{array}{l}\text { N155 } \\
\text { E902 }\end{array}$ & .031 & .038 & .038 & .029 & .008 \\
\hline Greenview Knolls Water Company & $67-001$ & Piney Point & $\begin{array}{l}\text { N157 } \\
\text { E945 }\end{array}$ & .065 & .048 & .051 & .045 & .044 \\
\hline James H1ll Tra1ler Park & $52-002$ & Piney Point & $\begin{array}{l}\text { K151 } \\
\text { E946 }\end{array}$ & .040 & .039 & .043 & .044 & .044 \\
\hline $\begin{array}{l}\text { King and Kennedy wells, St. Marys } \\
\text { Metropolitan Commission }\end{array}$ & $71-004$ & Aquia & $\begin{array}{l}\text { N203 } \\
\text { E897 }\end{array}$ & .021 & .019 & .018 & .015 & .011 \\
\hline Leonardtown, Town of & $67-003$ & Aquila & $\begin{array}{l}\mathrm{N} 169 \\
\mathbf{E} 904\end{array}$ & .310 & .335 & .287 & .220 & .205 \\
\hline Leonardtown High School & $67-009$ & Aquia & $\begin{array}{l}\text { N158 } \\
\text { E912 }\end{array}$ & .013 & .010 & .008 & .008 & .008 \\
\hline $\begin{array}{l}\text { Lexington Park, St. Marys } \\
\text { Metropolitan Comission }\end{array}$ & 46-001 & Aquia & $\begin{array}{l}\text { M156 } \\
\text { E954 }\end{array}$ & .694 & .726 & .730 & .864 & .680 \\
\hline Lundeburg School of Seamanship & $70-010$ & Aquia & $\begin{array}{l}\text { M111 } \\
\text { E944 }\end{array}$ & .085 & .096 & .096 & .096 & .096 \\
\hline Mayjack, Incorporated & $56-008$ & Piney Polnt & $\begin{array}{l}\mathrm{N169} \\
\mathrm{Eg} 22\end{array}$ & .038 & .026 & .030 & .025 & .027 \\
\hline Mt. Pleasant Water Company & $72-004$ & Aquia & $\begin{array}{l}N 170 \\
8874\end{array}$ & .011 & .008 & .006 & .005 & .004 \\
\hline Patuxent Naval Alr Station & $74-018$ & Piney Point & $\begin{array}{l}\text { N166 } \\
\text { E960 }\end{array}$ & .065 & .056 & .055 & .062 & .062 \\
\hline Patuxent Naval Air station & $74-018$ & Aquia & $\begin{array}{l}\text { N160 } \\
\mathbf{E 9 6 1}\end{array}$ & .765 & .780 & .761 & .902 & .870 \\
\hline Patuxent Naval Air Station & $74-018$ & Aquia & $\begin{array}{l}\text { N159 } \\
\text { E971 }\end{array}$ & .020 & .020 & .021 & .019 & .018 \\
\hline Patuxent Naval Air Station & $74-018$ & Pinøy Point & $\begin{array}{l}\text { K159 } \\
\mathbf{E} 971\end{array}$ & .020 & .020 & .021 & .019 & .018 \\
\hline Point Lookout State Park & $66-009$ & $\begin{array}{l}\text { Upper } \\
\text { Cretaceous }\end{array}$ & $\begin{array}{l}\text { No84 } \\
\text { E991 }\end{array}$ & .012 & .006 & .007 & .008 & .010 \\
\hline $\begin{array}{l}\text { Rolling Acres, St. Marys } \\
\text { Metrcpolitan Commission }\end{array}$ & $74-025$ & Aquia & $\begin{array}{l}\mathbf{K 2 4 1} \\
\mathbf{E} 881\end{array}$ & .021 & .015 & .013 & .012 & .008 \\
\hline $\begin{array}{l}\text { Southern Maryland Ut1lities } \\
\text { Company }\end{array}$ & 72-001 & Patapeco & $\begin{array}{l}1200 \\
E 844\end{array}$ & .010 & .010 & .010 & .010 & .012 \\
\hline St. Clements Shores Water Company & $65-002$ & Aquia & $\begin{array}{l}\text { K164 } \\
\mathbf{E} 887\end{array}$ & .032 & .024 & .028 & .028 & .027 \\
\hline St. Marys College & $69-001$ & Aquia & $\begin{array}{l}\text { N130 } \\
\mathrm{E} 964\end{array}$ & .055 & .055 & .052 & .052 & .051 \\
\hline Steuart Petroleum Company & $50-002$ & Aquia & $\begin{array}{l}\text { N116 } \\
\mathbf{E} 936\end{array}$ & .019 & .021 & .020 & .020 & .019 \\
\hline Steuart Petroleum Company & $50-002$ & Piney Point & $\begin{array}{l}\text { N115 } \\
\text { E935 }\end{array}$ & .020 & .003 & .003 & .003 & .003 \\
\hline Town Creek Water Company & $52-004$ & Piney Polnt & $\begin{array}{l}\mathrm{N} 172 \\
\mathrm{E} 946\end{array}$ & .152 & .132 & .128 & .144 & .156 \\
\hline $\begin{array}{l}\text { Wildewood, St. Marys Metropolitan } \\
\text { Commission }\end{array}$ & $76-014$ & Aquia & $\begin{array}{l}\text { N171 } \\
\text { E933 }\end{array}$ & .028 & .015 & .012 & .013 & .000 \\
\hline
\end{tabular}




\begin{tabular}{|c|c|c|c|c|c|c|c|c|c|c|c|}
\hline 1975 & 1974 & 1973 & 1972 & 1971 & 1970 & $1960-69$ & $1950-59$ & $1940-49$ & $1930-39$ & $1920-29$ & $1900-19$ \\
\hline 0.000 & 0.000 & 0.000 & 0.000 & 0.000 & 0.000 & 0.000 & 0.000 & 0.000 & 0.000 & $\begin{array}{l}0.000 \\
\text { First pumpage: }\end{array}$ & $: \begin{array}{l}0.000 \\
1976\end{array}$ \\
\hline .067 & .052 & .052 & .049 & .049 & .049 & .029 & .000 & .000 & .000 & $\begin{array}{l}.000 \\
\text { First pumpage: }\end{array}$ & $: 1968$ \\
\hline .011 & .011 & .008 & .008 & .008 & .008 & .006 & .005 & .000 & .000 & First $\stackrel{.000}{\text { pumpage: }}$ & $: .000$ \\
\hline .060 & .066 & .071 & .052 & .052 & .052 & .052 & .000 & .000 & .000 & First $\frac{.000}{\text { pumpage: }}$ & 1961 \\
\hline .000 & .000 & .000 & .000 & .000 & .000 & .000 & .000 & .000 & .000 & $\begin{array}{l}.000 \\
\text { First pumpage: }\end{array}$ & 1976 \\
\hline .008 & .008 & .008 & .008 & .008 & .007 & .004 & .003 & .000 & .000 & First pumpage: & $: 1977$ \\
\hline .008 & .008 & .008 & .008 & .008 & .008 & .008 & .000 & .000 & .000 & First pumpage: & 1.000 \\
\hline .041 & .038 & .036 & .036 & .033 & .033 & .019 & .007 & .000 & .000 & First pumpage: & $: 1959$ \\
\hline .047 & .037 & .038 & .038 & .049 & .048 & .049 & .049 & .000 & .000 & First pumpsge: & $: .000$ \\
\hline .010 & .008 & .007 & .005 & .003 & .000 & .000 & .000 & .000 & .000 & First pumpage: & $: .000$ \\
\hline .205 & .205 & .205 & .192 & .192 & .164 & .107 & .035 & .027 & .000 & First pumpage: & $: .000$ \\
\hline .007 & .006 & .006 & .005 & .005 & .005 & .004 & .000 & .000 & .000 & First pumpage: & $: .000$ \\
\hline .610 & .959 & .721 & .686 & .684 & .685 & .392 & .262 & .233 & .000 & First pumpage: & $: \stackrel{.000}{?}$ \\
\hline .096 & .096 & .096 & .096 & .096 & .096 & .070 & .008 & .000 & .000 & First pumpage: & 1.000 \\
\hline .027 & .027 & .026 & .015 & .015 & .015 & .015 & .010 & .005 & .000 & First purnpage: & $: 1940$ \\
\hline .003 & .002 & .002 & .000 & .000 & .000 & .000 & .000 & .000 & .000 & First .000 & $: 1973$ \\
\hline .075 & .069 & .073 & .073 & .073 & .082 & .122 & .154 & .101 & .000 & First pumpage: & $: .000$ \\
\hline .831 & .839 & .765 & .841 & .999 & 1.158 & .836 & 1.291 & 1.489 & .000 & First purnpage: & 1944 \\
\hline .022 & .027 & .026 & .028 & .042 & .046 & .032 & .032 & .031 & .000 & First pumpage: & $: \stackrel{.000}{?}$ \\
\hline .023 & .027 & .027 & .028 & .042 & .046 & .032 & .032 & .032 & .000 & First $\stackrel{.000}{\text { pumpage: }}$ & 1.000 \\
\hline .010 & .010 & .010 & .010 & .010 & .003 & .003 & .000 & .000 & .000 & First pumpage: & 1961 \\
\hline .008 & .008 & .004 & .004 & .004 & .004 & .004 & .000 & .000 & .000 & $\begin{array}{c}.000 \\
\text { First pumpage: }\end{array}$ & 1.000 \\
\hline .015 & .014 & .000 & .000 & .000 & .000 & .000 & .000 & .000 & .000 & First pumpage: & $: 1974$ \\
\hline .025 & .026 & .028 & .024 & .022 & .022 & .000 & .000 & .000 & .000 & $\begin{array}{l}.000 \\
\text { First pumpage: }\end{array}$ & $: 1970$ \\
\hline .049 & .049 & .048 & .047 & .047 & .046 & .031 & .016 & .014 & .011 & $\begin{array}{l}.000 \\
\text { First pumpage : }\end{array}$ & $: .000$ \\
\hline .026 & .029 & .025 & .021 & .021 & .023 & .021 & .021 & .000 & .000 & First pumpage: & 19000 \\
\hline .004 & .005 & .004 & .004 & .004 & .002 & .002 & .002 & .000 & .000 & $\begin{array}{l}.000 \\
\text { First purnpage: }\end{array}$ & 1.000 \\
\hline .115 & .118 & .118 & .118 & .082 & .082 & .082 & .082 & .000 & .000 & First pumpage: & 1953 \\
\hline .000 & .000 & .000 & .000 & .000 & .000 & .000 & .000 & .000 & .000 & First pumpage: & $: 19000$ \\
\hline
\end{tabular}


Ground-water withdrawals by large users in somerset Count, 1900 through 1980

(Sources: Maryland Water Resources Administration files, Maryland Geological Survey reports, county water and sewerage plans, and miscellaneous county reports)

\begin{tabular}{|c|c|c|c|c|c|c|c|c|}
\hline User & $\begin{array}{l}\text { Appropriation } \\
\text { number }\end{array}$ & Aquifer & $\begin{array}{l}\text { Maxyland grid } \\
\text { coordinates }\end{array}$ & 1980 & 1979 & 1978 & 1977 & 1976 \\
\hline Carvel Hall Cutlery & $51-001$ & Quaternary & $\begin{array}{l}\text { No62 } \\
\mathbf{E} 1137\end{array}$ & 0.000 & 0.000 & 0.000 & 0.000 & 0.000 \\
\hline Chesapeake Bay Plywood Corporation & $66-004$ & Pocomoke & $\begin{array}{l}\text { No91 } \\
\text { E1207 }\end{array}$ & .186 & .220 & .166 & .197 & .192 \\
\hline Chesapeake $E_{88}$ Corporation & $65-002$ & Pocomoke & $\begin{array}{l}\text { xo98 } \\
\text { E1215 }\end{array}$ & .000 & .000 & .000 & .001 & .003 \\
\hline Crisfield, City of & $72-006$ & Magothy & $\begin{array}{l}\text { No57 } \\
\mathrm{E} 1132\end{array}$ & .812 & .777 & .972 & .853 & .870 \\
\hline Crisfield, City of & $72-006$ & Patapsco & $\begin{array}{l}\text { Yos8 } \\
\mathrm{E} 1132\end{array}$ & .079 & .228 & .201 & .265 & .142 \\
\hline $\begin{array}{l}\text { Princess Anne, Somerset County } \\
\text { Sanitary District }\end{array}$ & $79-005$ & Manokin & $\begin{array}{l}1137 \\
\mathbf{E} 1173\end{array}$ & .342 & .342 & .342 & .342 & .342 \\
\hline $\begin{array}{l}\text { Frenchtown, Somerset County } \\
\text { Sanitary District }\end{array}$ & $80-007$ & Patapsco & $\begin{array}{l}\text { No93 } \\
\text { E1127 }\end{array}$ & .013 & .000 & .000 & .000 & .000 \\
\hline
\end{tabular}

Ground-water withdrawals by Large users in Talbot Cocnts, 1800 through 1880

(Sources: Maryland Water Resources Administration files, Maryland Geological Survey reports, county water and sewerage plans, and miscellaneous county roports)

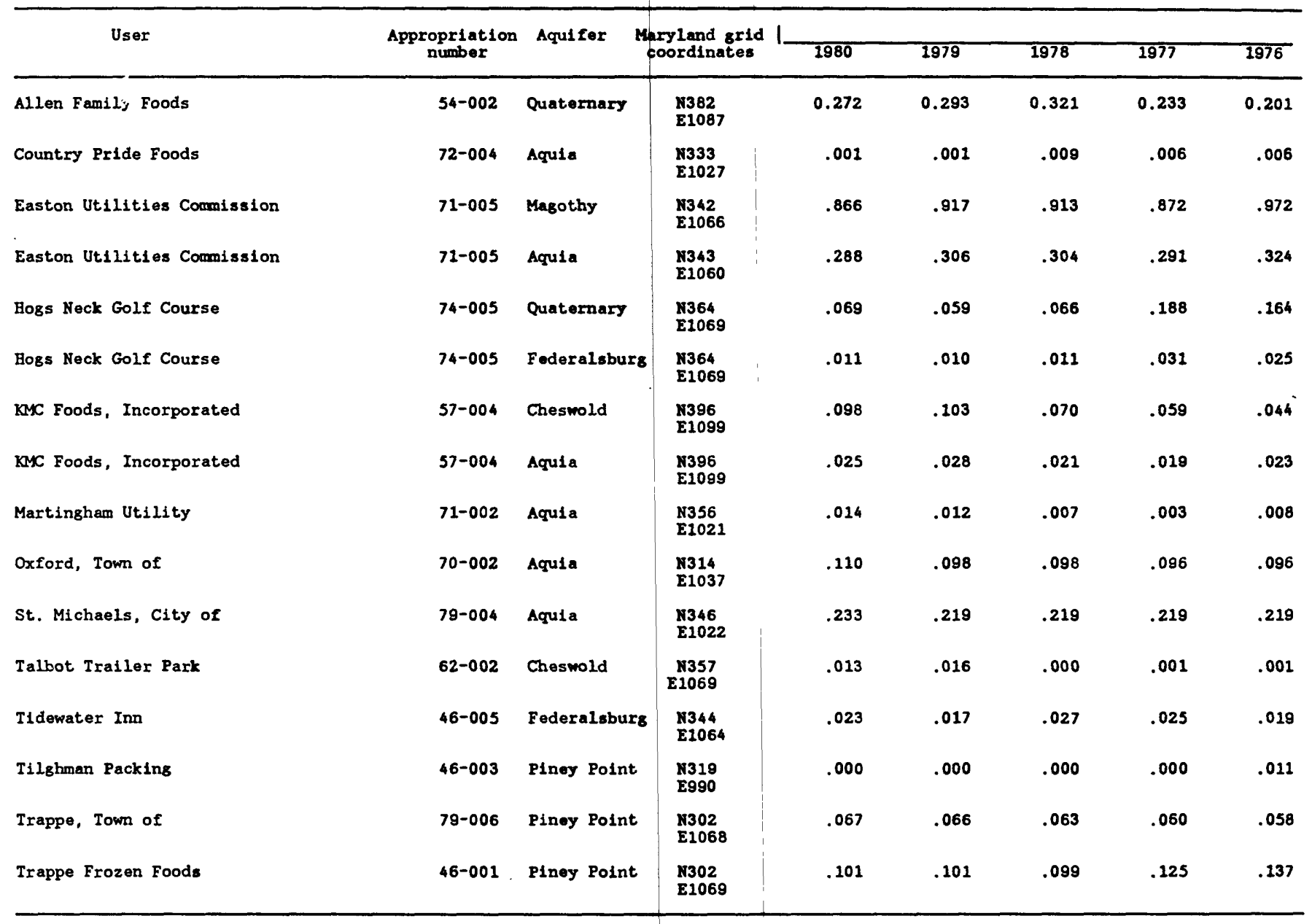




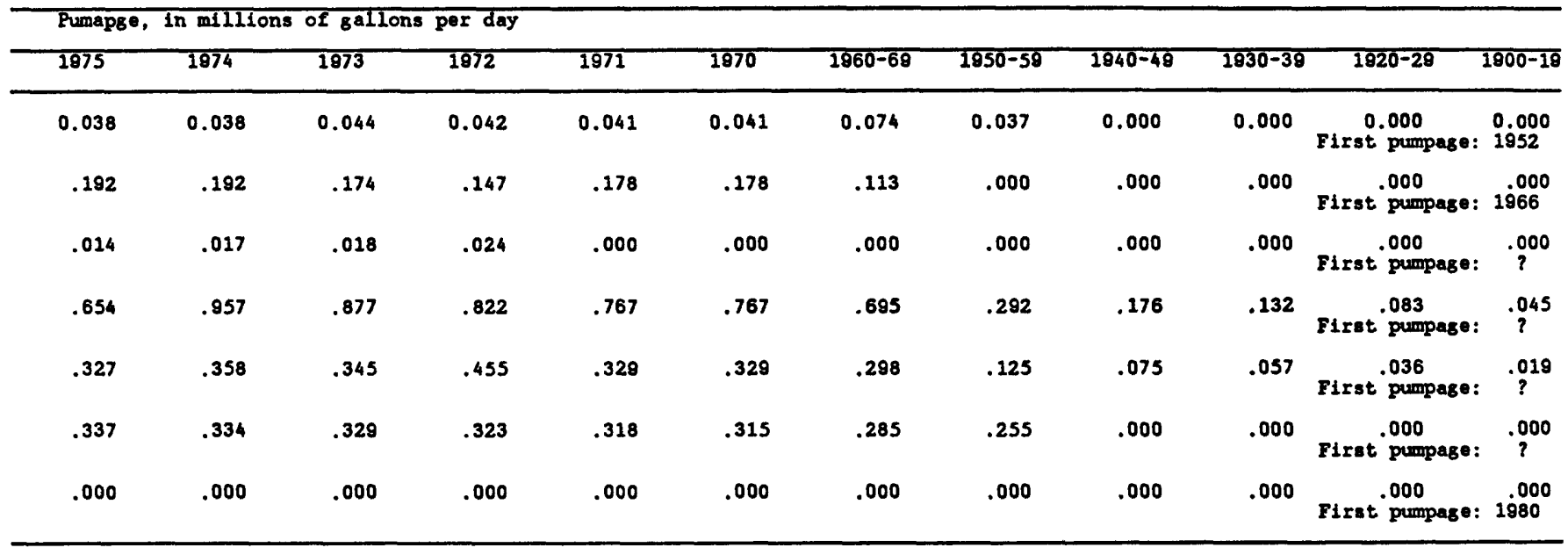

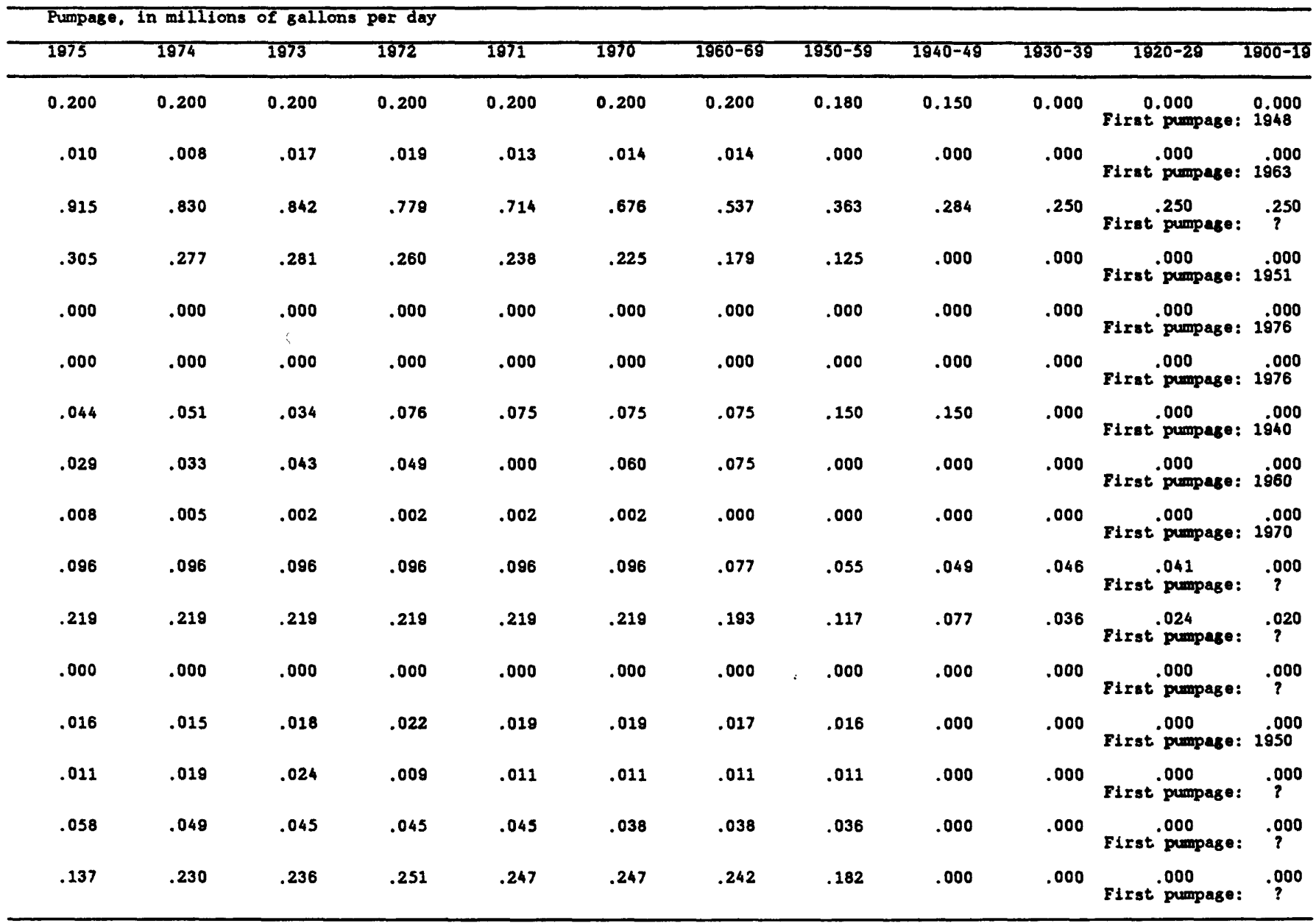


Ground-water withdrawals by large users in Wiconico County, 1900 through 1980

(Sources: Maryland Water Resources Administration files, Maryland Geological Survey reports, county water and sewerage plans, and miscellaneous county reports)

\begin{tabular}{|c|c|c|c|c|c|c|c|c|}
\hline User & $\begin{array}{l}\text { Appropriation } \\
\text { number }\end{array}$ & Aquifer & $\begin{array}{l}\text { Maryland grid } \\
\text { coordinates }\end{array}$ & 1980 & 1979 & 1978 & 1977 & 1976 \\
\hline A.W. Perdue and Son, Incorporated & $55-001$ & Quaternary & $\begin{array}{l}\mathbf{R} 204 \\
\mathrm{E} 1222\end{array}$ & 1.577 & 1.496 & 1.527 & 1.475 & 1.664 \\
\hline Campbell Soup, Incorporated & $66-007$ & Quaternary & $\begin{array}{l}\text { N200 } \\
\text { E1198 }\end{array}$ & .865 & .979 & 1.134 & 1.228 & .841 \\
\hline Champion Chick Products Corporation & 46-001 & Manokin & $\begin{array}{l}\mathbf{N 1 6 0} \\
\mathrm{E} 1113\end{array}$ & .000 & .000 & .000 & .013 & .012 \\
\hline Chesapeake Foods, Incorporated & $63-001$ & Quaternary & $\begin{array}{l}\text { N173 } \\
\text { E1247 }\end{array}$ & .297 & .315 & .293 & .288 & .274 \\
\hline Chesapeake Growers, Incorporated & $77-002$ & Quaternary & $\begin{array}{l}\text { N172 } \\
\text { E1245 }\end{array}$ & .018 & .016 & .015 & .015 & .015 \\
\hline Delmarva Power and Light Company & $56-002$ & Manokin & $\begin{array}{l}\mathrm{N} 213 \\
\mathrm{E} 1210\end{array}$ & .029 & .044 & .046 & .085 & .125 \\
\hline Fruitland, City of & $77-041$ & Quaternary & $\begin{array}{l}\mathrm{N} 181 \\
\mathrm{E} 1200\end{array}$ & .173 & .048 & .000 & .000 & .000 \\
\hline Green Giant Company & $67-012$ & Manokin & $\begin{array}{l}\text { N182 } \\
\text { E1197 }\end{array}$ & .004 & .369 & .341 & .326 & .314 \\
\hline Green Giant Company & $67-012$ & Quaternary & $\begin{array}{l}\text { N182 } \\
\text { E1197 }\end{array}$ & .000 & .019 & .018 & .017 & .016 \\
\hline B.B.Kennerly and Sons, Incorporated & $68-005$ & Manokin & $\begin{array}{l}\text { N160 } \\
\text { E1112 }\end{array}$ & .015 & .014 & .008 & .004 & .004 \\
\hline Boliday Inn & $62-002$ & Manokin & $\begin{array}{l}\text { N215 } \\
\text { E1211 }\end{array}$ & .007 & .003 & .004 & .005 & .005 \\
\hline Boliday Inn & $62-002$ & Quaternary & $\begin{array}{l}\text { N214 } \\
\mathrm{E} 1212\end{array}$ & .007 & .003 & .004 & .005 & .005 \\
\hline Mardella School & $79-008$ & Frederica & $\begin{array}{l}\text { N233 } \\
\text { E1159 }\end{array}$ & .010 & .001 & .001 & .001 & .001 \\
\hline Messick Ice Company & $56-001$ & Quaternaxy & $\begin{array}{l}\text { N196 } \\
\text { E1203 }\end{array}$ & .609 & .595 & .571 & .576 & .578 \\
\hline Poplar Bill Correction Camp & 59-001 & Manokin & $\begin{array}{l}\text { N194 } \\
\text { E1151 }\end{array}$ & .024 & .024 & .024 & .024 & .024 \\
\hline Salisbury, City of & 73-001 & Quaternary & $\begin{array}{l}\text { N197 } \\
\text { E1208 }\end{array}$ & 3.874 & 3.375 & 3.438 & 4.312 & 4.038 \\
\hline Salisbury Mobile Bome Park & $66-001$ & Quaternary & $\begin{array}{l}\text { N212 } \\
\text { E1211 }\end{array}$ & .015 & .014 & .014 & .014 & .014 \\
\hline Sharptown, City of & $75-021$ & Quaternary & $\begin{array}{l}\text { N259 } \\
\text { E1169 }\end{array}$ & .074 & .061 & .068 & .000 & .000 \\
\hline Shockley and Son, Incorporated & $62-009$ & Manokin & $\begin{array}{l}\text { K170 } \\
\text { E1267 }\end{array}$ & .032 & .027 & .025 & .025 & .025 \\
\hline Shoreland Freezers, Incorporated & $63-003$ & Quaternary & $\begin{array}{l}\text { N189 } \\
\mathrm{E} 1202\end{array}$ & .053 & .071 & .063 & .055 & .055 \\
\hline
\end{tabular}




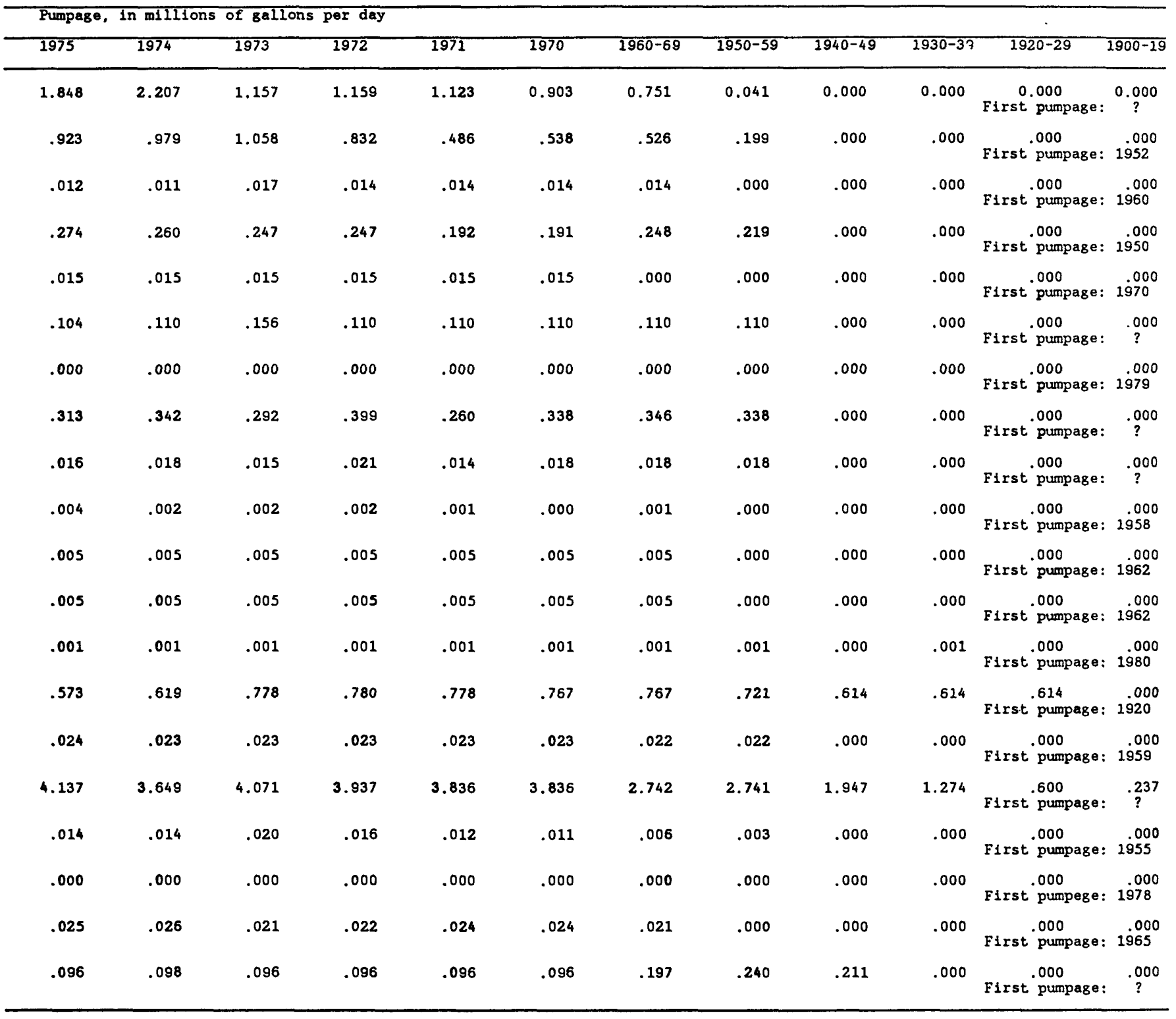


Ground-water withdrewals by Inrge users in torcester Counts, 1900 throush 1980

(Sources: Maryland Water Resources Administration files, Maryland Geological Survey reports, county water and sewerage plans, and miscellaneous county reports)

\begin{tabular}{|c|c|c|c|c|c|c|c|c|}
\hline User & $\begin{array}{l}\text { Appropriation } \\
\text { number }\end{array}$ & Aquifer & $\begin{array}{l}\text { Maryland } 8 \text { rid } \\
\text { coordinates }\end{array}$ & 1980 & 1979 & 1978 & 1977 & $\overline{1976}$ \\
\hline Campbell Soup Company & $67-006$ & Pocomoke & $\begin{array}{l}\text { K088 } \\
\mathbf{E} 1209\end{array}$ & 0.317 & 0.330 & 0.377 & 0.383 & 0.647 \\
\hline Chesapeake Foods & $56-005$ & Pocomoke & $\begin{array}{l}\text { N188 } \\
\text { E1311 }\end{array}$ & .373 & .531 & .558 & .672 & .532 \\
\hline Berlin, City of & $80-004$ & Quaternary & $\begin{array}{l}\text { N185 } \\
\text { E1311 }\end{array}$ & .411 & .411 & .411 & .411 & .411 \\
\hline Davis Ice, Incorporated & 55-003 & Quaternary & $\begin{array}{l}\text { N184 } \\
\text { E1309 }\end{array}$ & .289 & .281 & .281 & .298 & .248 \\
\hline General Motors Inns, Incorporated & $66-009$ & Pocomoke & $\begin{array}{l}\text { No83 } \\
\text { E2217 }\end{array}$ & .002 & .002 & .002 & .003 & .003 \\
\hline Holly Farms, Incorporated & $70-005$ & Manokin & $\begin{array}{l}\text { K134 } \\
\text { E1256 }\end{array}$ & .026 & .028 & .029 & .024 & .024 \\
\hline $\begin{array}{l}\text { J.W. Shockloy and Sons Fish } \\
\text { Hatchery }\end{array}$ & $63-003$ & Quaternary & $\begin{array}{l}\text { N169 } \\
\text { E1266 }\end{array}$ & .000 & .000 & .000 & .000 & .000 \\
\hline Margland Marine Utilities & $68-010$ & Quaternary & $\begin{array}{l}1210 \\
\mathbf{E} 1325\end{array}$ & .252 & .213 & .174 & .215 & .185 \\
\hline Mason Canning Company & $61-009$ & Pocomoke & $\begin{array}{l}\mathrm{N1S7} \\
\mathbf{E} 1290\end{array}$ & .000 & .000 & .000 & .000 & .000 \\
\hline Mason Canning Company & $61-009$ & Quaternary & $\begin{array}{l}\mathbf{1 1 6 1} \\
\mathbf{2 1 3 0 2}\end{array}$ & .000 & .000 & .000 & .000 & .000 \\
\hline $\begin{array}{l}\text { Newark. Worcester County } \\
\text { Sanitary Coumission }\end{array}$ & $71-006$ & Poconoke & $\begin{array}{l}\text { M156 } \\
\text { E1292 }\end{array}$ & .014 & .011 & .013 & .012 & .008 \\
\hline Ocean City Convention Ball & $68-008$ & Manokin & $\begin{array}{l}\text { X199 } \\
\mathbf{E} 1353\end{array}$ & .016 & .002 & .002 & .002 & .815 \\
\hline $\begin{array}{l}\text { Ocean City Golf and Yacht Club, } \\
\text { Incorporated }\end{array}$ & None & Quaternary & $\begin{array}{l}\text { N156 } \\
\mathbf{E} 1324\end{array}$ & .019 & .004 & .024 & .024 & .019 \\
\hline $\begin{array}{l}\text { Ocean City Golf and Yacht Club, } \\
\text { Incorporated }\end{array}$ & $58-005$ & Pocomoke & $\begin{array}{l}\text { N158 } \\
\text { E1322 }\end{array}$ & .019 & .004 & .024 & .026 & .019 \\
\hline Ocean City, 15th Street wells & 71-005 & Manokin & $\begin{array}{l}\mathbf{N 1 9 2} \\
\mathbf{2} 1350\end{array}$ & .403 & .454 & .722 & .800 & .676 \\
\hline Ocean City, 44th Street wells & $71-005$ & Manokin & $\begin{array}{l}\mathbf{X 2 0 0} \\
\mathbf{E} 1352\end{array}$ & 1.339 & 1.504 & 1.575 & 1.173 & 1.289 \\
\hline Ocean City. Gorman Avenue wells & $71-005$ & Manokin & $\begin{array}{l}\text { M227 } \\
\text { E1356 }\end{array}$ & .970 & 1.091 & .871 & .976 & .789 \\
\hline Ocean Clty, south end wells & 71-005 & Manokin & $\begin{array}{l}\text { H186 } \\
\text { E1346 }\end{array}$ & .899 & .993 & .767 & .761 & .891 \\
\hline Ocean City & $71-005$ & Manokin & $\begin{array}{l}1185 \\
51345\end{array}$ & .000 & .000 & .000 & .000 & .000 \\
\hline $\begin{array}{l}\text { Ocean Downs Racing Association, } \\
\text { Incorporated }\end{array}$ & $67-005$ & Quaternary & $\begin{array}{l}\text { N194 } \\
\text { E1331 }\end{array}$ & .051 & .067 & .049 & .045 & .045 \\
\hline Ocean Pines Association, Incorporated & $78-002$ & Quaternary & $\begin{array}{l}\mathbf{1 2 0 7} \\
\mathbf{E} 1328\end{array}$ & .113 & .070 & .086 & .082 & .082 \\
\hline Perdue, Incorporated & 69-002 & Quaternary & $\begin{array}{l}\text { KOB4 } \\
\text { E1258 }\end{array}$ & .465 & .822 & .807 & .733 & .812 \\
\hline Pine Shore Golf, Incorporated & 79-004 & Quaternary & $\begin{array}{l}\mathbf{1 2 0 7} \\
\mathbf{2 1 3 2 0}\end{array}$ & .047 & .000 & .000 & .000 & .000 \\
\hline Pocomoke City & 79-010 & Poconoke & $\begin{array}{l}\mathbf{1 0 9 0} \\
\mathbf{E} 1214\end{array}$ & .574 & .303 & .303 & .303 & .303 \\
\hline Poconoke State Park & $63-004$ & Manokin & $\begin{array}{l}\text { K115 } \\
\text { E1248 }\end{array}$ & .008 & .008 & .008 & .010 & .010 \\
\hline Quality Inn & 65-004 & Pocomoke & $\begin{array}{l}\text { No78 } \\
\text { E1219 }\end{array}$ & .011 & .019 & .022 & .021 & .021 \\
\hline
\end{tabular}




\begin{tabular}{|c|c|c|c|c|c|c|c|c|c|c|c|}
\hline 1975 & 1974 & 1973 & 1972 & 1971 & 1970 & $1960-69$ & $1950-59$ & $1940-49$ & $1930-39$ & $1920-29$ & $1900-19$ \\
\hline 0.949 & 0.696 & 0.678 & 0.954 & 0.913 & 0.852 & 0.269 & 0.144 & 0.000 & 0.000 & $\begin{array}{l}0.000 \\
\text { First pumpage: }\end{array}$ & $\begin{array}{l}0.000 \\
1856\end{array}$ \\
\hline .507 & .704 & .773 & 1.141 & .859 & .712 & .462 & .196 & .000 & .000 & First pumpage: & 19000 \\
\hline .411 & .411 & .411 & .411 & .411 & .411 & .282 & .145 & .097 & .077 & First pumpage: & $\stackrel{.050}{?}$ \\
\hline 1.053 & .889 & .677 & .685 & .685 & .685 & .670 & .633 & .589 & .479 & First $\stackrel{-479}{\text { pumpage: }}$ & $: .479$ \\
\hline .007 & .010 & .004 & .003 & .000 & .003 & .002 & .000 & .000 & .000 & First .000 & $: .000$ \\
\hline .024 & .022 & .021 & .019 & .019 & .019 & .015 & .012 & .000 & .000 & F1rst $\stackrel{.000}{\text { pumpage: }}$ & $: 1954$ \\
\hline .000 & .000 & .014 & .008 & .009 & .008 & .007 & .004 & .000 & .000 & First pumpage: & $: .000$ \\
\hline .168 & .135 & .096 & .065 & .052 & .036 & .021 & .000 & .000 & .000 & First $\stackrel{.000}{\text { pumpage: }}$ & $: .000$ \\
\hline .000 & .000 & .000 & .000 & .007 & .019 & .011 & .011 & .000 & .000 & First $\stackrel{.000}{\text { pumpage }}$ & $=1950$ \\
\hline .000 & .000 & .000 & .000 & .021 & .030 & .034 & .033 & .040 & .000 & First $\stackrel{.000}{\text { pumpage }}$ & $: 1900$ \\
\hline .010 & .011 & .010 & .003 & .004 & .004 & .003 & .000 & .000 & .000 & First $\stackrel{.000}{\text { pumpage: }}$ & $: 1972$ \\
\hline .815 & .815 & .815 & .815 & .815 & .002 & .050 & .000 & .000 & .000 & First pumpage: & $: .000$ \\
\hline .016 & .021 & .012 & .014 & .016 & .016 & .014 & .000 & .000 & .000 & First pumpage: & $: \quad: 000$ \\
\hline .016 & .021 & .012 & .014 & .016 & .016 & .014 & .000 & .000 & .000 & First $\stackrel{.000}{\text { pumpage: }}$ & 1.000 \\
\hline .570 & .891 & .682 & .363 & .665 & .000 & .000 & .000 & .000 & .000 & First pumpage: & $: 1.000$ \\
\hline 1.099 & 1.130 & .011 & .749 & .635 & .000 & .000 & .000 & .000 & .000 & First pumpage: & $: 19000$ \\
\hline .482 & .322 & .000 & .000 & .000 & .000 & .000 & .000 & .000 & .000 & First .000 & $: 1974$ \\
\hline .690 & .785 & .758 & .865 & .405 & .000 & .000 & .000 & .000 & .000 & First pumpage: & $: 1971$ \\
\hline .000 & .000 & .000 & .000 & .000 & 2.192 & .980 & .616 & .522 & .363 & First $\stackrel{.226}{\text { pumpage: }}$ & $: \frac{.150}{?}$ \\
\hline .044 & .044 & .041 & .012 & .011 & .010 & .007 & .005 & .004 & .000 & First $\stackrel{.000}{\text { pumpage: }}$ & $: 1949$ \\
\hline .082 & .082 & .082 & .082 & .082 & .000 & .000 & .000 & .000 & .000 & First pumpage: & $: 1900$ \\
\hline .796 & .858 & .769 & .685 & .548 & .411 & .239 & .000 & .000 & .000 & First pumpage: & $: \stackrel{.000}{?}$ \\
\hline .000 & .000 & .000 & .000 & .000 & .000 & .000 & .000 & .000 & .000 & First pumpage: & $: 1980$ \\
\hline .303 & .301 & .301 & .301 & .301 & .301 & .310 & .410 & .423 & .308 & First .171 & $: \begin{array}{l}.090 \\
: 1918\end{array}$ \\
\hline .010 & .010 & .010 & .010 & .010 & .010 & .011 & .000 & .000 & .000 & First .000 & $: 1960$ \\
\hline .022 & .021 & .022 & .021 & .021 & .020 & .022 & .000 & .000 & .000 & First $\stackrel{.000}{\text { pumpage }}$ & $: 1968$ \\
\hline
\end{tabular}


Ground-water withdrewals by large users in Worcester Counts. 1900 throush 1880--Continued

\begin{tabular}{|c|c|c|c|c|c|c|c|c|}
\hline User & $\begin{array}{l}\text { Appropriation } \\
\text { number }\end{array}$ & Aquifer & $\begin{array}{l}\text { Maryland grid } \\
\text { coordinates }\end{array}$ & 1980 & 1979 & 1978 & 1977 & 1976 \\
\hline Ralph L. Mason, Incorporated & $78-004$ & Pocomoke & $\begin{array}{l}\mathrm{N} 156 \\
\mathrm{E} 1290\end{array}$ & 0.007 & 0.008 & 0.013 & 0.010 & 0.010 \\
\hline Ralph L. Mason, Incorporated & $78-004$ & Quatermaxy & $\begin{array}{l}\text { N156 } \\
\mathrm{E} 1290\end{array}$ & .000 & .000 & .000 & .000 & .000 \\
\hline Ross Wells, Incorporated & $69-004$ & Quatermany & $\begin{array}{l}\text { R189 } \\
\text { E1314 }\end{array}$ & .010 & .015 & .013 & .023 & .032 \\
\hline Savage Ice Company & $51-005$ & Quaternary & $\begin{array}{l}N 186 \\
\mathrm{E} 1348\end{array}$ & .000 & .000 & .000 & .055 & .106 \\
\hline Savage Ice Company & $51-005$ & Pocomoke & $\begin{array}{l}\mathrm{N} 186 \\
\mathrm{E} 1348\end{array}$ & .041 & .055 & .055 & .003 & .004 \\
\hline Showell Fsrms, Incorporated & $51-003$ & Quatermang & $\begin{array}{l}\mathbf{X} 11 \\
\mathrm{E} 1312\end{array}$ & .883 & 1.071 & .927 & .681 & .841 \\
\hline Showell Farms, Incorporated & $71-001$ & Quaternaty & $\begin{array}{l}\mathbf{M 2 2 1} \\
\mathbf{E} 1309\end{array}$ & .011 & .007 & .004 & .004 & .003 \\
\hline Showell Fsrms, Incorporated & $78-007$ & Quaternary & $\begin{array}{l}\text { N229 } \\
\mathbf{E} 1317\end{array}$ & .075 & .037 & .027 & .027 & .011 \\
\hline Snow Hill, Town of & $79-013$ & Manokin & $\begin{array}{l}\text { N130 } \\
\text { E1262 }\end{array}$ & .335 & .260 & .260 & .260 & .260 \\
\hline
\end{tabular}




\begin{tabular}{|c|c|c|c|c|c|c|c|c|c|c|c|}
\hline 1975 & 1974 & 1973 & 1972 & 1971 & 1970 & $1960-69$ & $1950-59$ & $1940-49$ & $1930-39$ & $1920-29$ & $1900-19$ \\
\hline 0.010 & 0.010 & 0.010 & 0.010 & 0.010 & 0.010 & 0.009 & 0.008 & 0.000 & 0.000 & $\begin{array}{c}0.000 \\
\text { First pumpage: }\end{array}$ & $\begin{array}{l}0.000 \\
1952\end{array}$ \\
\hline .000 & .000 & .000 & .000 & .000 & .000 & .000 & .007 & .005 & .004 & First pumpage: & $? .000$ \\
\hline .028 & .026 & .027 & .025 & .025 & .025 & .002 & .000 & .000 & .000 & First pumpage: & 1969 \\
\hline .094 & .096 & .100 & .203 & .082 & .055 & .055 & .042 & .020 & .000 & First pumpage: & 1940 \\
\hline .011 & .004 & .004 & .003 & .003 & .000 & .000 & .000 & .000 & .000 & First pumpage: & 1971 \\
\hline 1.154 & 1.046 & 1.003 & .876 & .822 & .822 & .458 & .088 & .000 & .000 & First pumpage: & 1950 \\
\hline .003 & .003 & .003 & .000 & .000 & .000 & .000 & .000 & .000 & .000 & First pumpage: & 19000 \\
\hline .011 & .011 & .011 & .011 & .011 & .011 & .011 & .009 & .000 & .000 & First pumpage: & 1952 \\
\hline .260 & .260 & .260 & .260 & .260 & .260 & .260 & .260 & .216 & .134 & First pumpage: & .023 \\
\hline
\end{tabular}

